
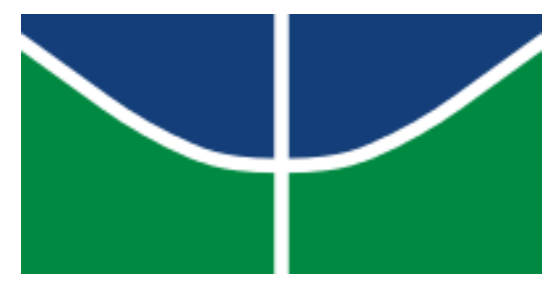

UNIVERSIDADE DE BRASÍLIA

INSTITUTO DE HUMANAS

PROGRAMA DE PÓS-GRADUAÇÃO EM HISTÓRIA - PPGHIS

BRUNA SANTANA DE SÁ FERREIRA

O CHOQUE DAS RAÇAS: EUGENIA, LITERATURA E IMPRENSA EM MONTEIRO LOBATO

BRASÍLIA,

2016 

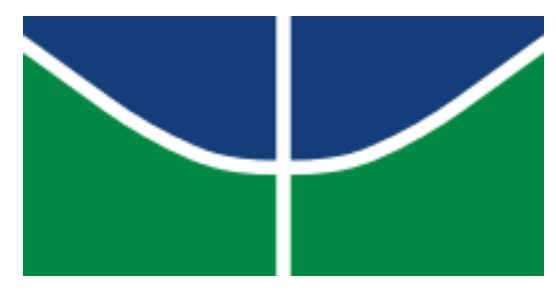

UNIVERSIDADE DE BRASÍLIA

INSTITUTO DE HUMANAS

PROGRAMA DE PÓS-GRADUAÇÃO EM HISTÓRIA - PPGHIS

BRUNA SANTANA DE SÁ FERREIRA

O CHOQUE DAS RAÇAS: EUGENIA, LITERATURA E IMPRENSA EM MONTEIRO LOBATO

\begin{abstract}
Dissertação apresentada ao Programa de PósGraduação em História. Linha de pesquisa: História Social e suas múltiplas formas da Universidade de Brasília para a obtenção do título de Mestre em História.
\end{abstract}

Orientador: Prof. Dr. Marcelo Balaban

BRASÍLIA, 
BRUNA SANTANA FERNANDES

\title{
O CHOQUE DAS RAÇAS: EUGENIA, LITERATURA E IMPRENSA EM MONTEIRO LOBATO
}

\author{
Dissertação apresentada ao Programa de Pós- \\ Graduação em História. Linha de pesquisa: \\ História Social e suas múltiplas formas da \\ Universidade de Brasília para a obtenção do título \\ de Mestre em História.
}

BANCA EXAMINADORA

Prof. Dr. Marcelo Balaban (PPGHIS-UnB - orientador)

Prof. ${ }^{a}$ Dr. ${ }^{a}$ Paula Arantes Botelho Briglia Habib (Ministério da Educação)

Prof. Dr. Daniel Barbosa Andrade de Faria (PPGHIS-UnB)

Prof. ${ }^{a}$ Dr. ${ }^{a}$ Neuma Brilhante Rodrigues (PPGHIS-UnB - Suplente)

BRASÍLIA, 


\section{Agradecimentos}

Ao longo dos tortuosos dois anos de pesquisa, algumas pessoas se fizeram especiais em minha trajetória e, por isso, merecem o devido reconhecimento. Inicio agradecendo a minha família, meu grande alicerce, sem o qual não conseguiria chegar tão longe. Amplio esse agradecimento a todos e todas que, mesmo de longe, estavam torcendo por mim. Agradeço ao meu pai, minha mãe, meu padrasto e meu irmão pelo amor incondicional e pelas palavras de incentivo.

Ao meu orientador, professor Marcelo Balaban, agradeço pelas orientações impecáveis, pelo olhar carinhoso e humano para com os seus alunos. Um professor compreensivo, paciente, e sempre à disposição nos momentos de maior angústia. Humildemente, transmite seu conhecimento e incentiva ideias até então fragmentadas. Agradeço, principalmente, pela amizade e respeito que foram construídos ao longo de todos esses anos de parceria.

Estendo esse agradecimento aos professores e funcionários PPGHIS-UnB que compartilharam seus conhecimentos e participaram da minha formação acadêmica, estimulando-me o gosto pelo saber e pela pesquisa histórica. Agradeço, também, aos colegas da pós que dividiram comigo as dores e delícias de ser uma mestranda. Minha profunda gratidão à amiga que as adversidades da vida me deu, Sylvia Senna. Obrigada pelas conversas e risadas semanais, as quais me fizeram refletir e transformar a vida mais leve.

$\mathrm{E}$, finalmente, o meu mais profundo e sincero agradecimento ao meu companheiro de vida, Moacir de Sá Ferreira. Obrigada pelos conselhos, pelo apoio incomparável, pelas piadinhas nerds, pelas revisões, pelas palavras de autoestima e, principalmente, obrigada pelo sincero amor, sem o qual não conseguiria concluir este trabalho. 


\section{Resumo}

Este presente estudo propõe-se a analisar o único romance do escritor paulista Monteiro Lobato, $O$ Choque das Raças. Primeiramente publicado no jornal carioca $A$ Manhã, em 1926, essa obra literária traz em seu cerne o debate sobre a miscigenação, tema muito discutido nas primeiras décadas do século XX. Romance de caráter pedagógico, futurista e eugenista, $O$ Choque das Raças tem como objetivo apresentar os malefícios ocasionados pelas misturas raciais e sugerir uma alternativa possível para esse infortúnio social brasileiro. Para isso, utiliza-se de uma narrativa futurística para fisgar o leitor e apresentar as evidências positivas dessa ciência nos Estados Unidos de 2228. Desta forma, a proposta desta dissertação é compreender as falas das personagens do romance à luz de textos e fontes da imprensa dos anos 1920, bem como entender as interlocuções internas da narrativa com o seu contexto histórico.

Palavras-chave: $O$ Choque das Raças; Monteiro Lobato; Eugenia; Imprensa; A Manhã. 


\begin{abstract}
This research aims to analyze the only novel of the Brazilian writer Monteiro Lobato, O Choque das Raças. Initially published in 1926 at the newspaper A Manhã. This pedagocical, futuristic and eugenicist novel presents the damaging effects caused by the mixing of different racial groups and suggest a possible alternative to this Brazilian social disgrace. Therefore, it uses a futurist narrative that captures the reader and shows the positive evidence of United States' science in 2228. Thus, we intend to understand the speech that express the characters in the light of the texts and the press of the 1920s, as well as perceive the internal dialogues of the narrative with their historical context.
\end{abstract}

Keywords: $O$ Choque das Raças; Monteiro Lobato; Eugenics; Press; A Manhã. 


\section{Sumário}

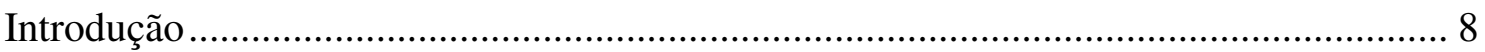

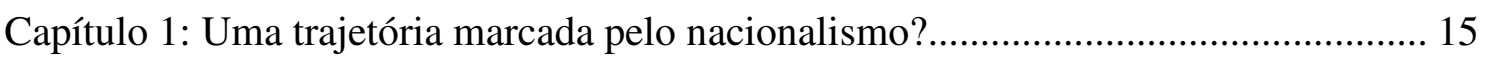

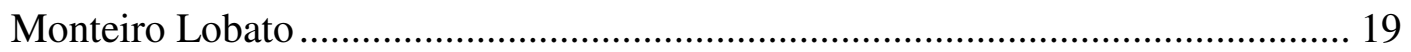

De menino Juca ao fazendeiro do Buquira .......................................................... 20

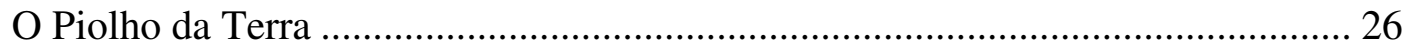

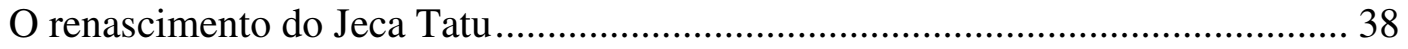

O editor e proprietário da Revista do Brasil ......................................................... 49

Capítulo 2: O Choque das Raças: “A imaginação a serviço da lógica”.......................... 60

O Choque das Raças na A Manhãa....................................................................... 63

Um romance em prol de uma "sábia ciência" ....................................................... 69

Associação Negra, Partido Masculino e Partido Feminino: os três partidos norte-

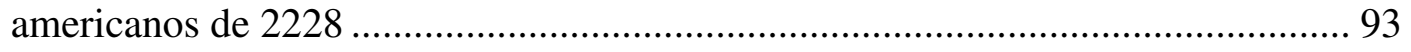

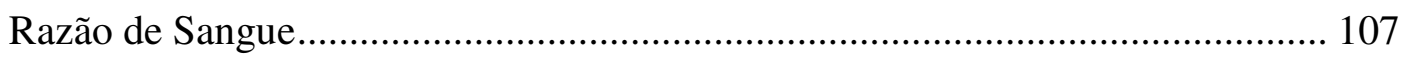

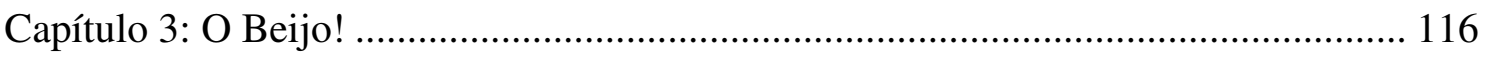

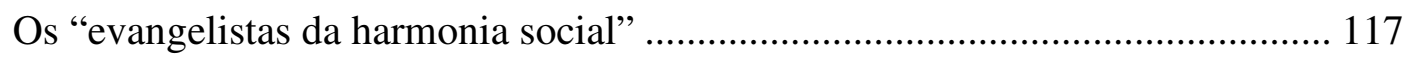

"A escola não faz o homem" .......................................................................... 133

Monteiro Lobato, um apóstolo eugenista …..................................................... 145

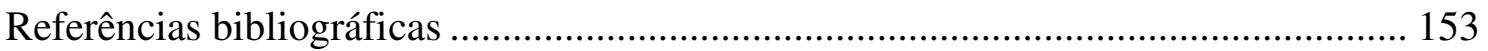




\section{Introdução}

As primeiras décadas do século XX, no Brasil, foram marcadas por um debate ideológico que buscava entender e discutir a nação. Para alguns, era necessário definir as características próprias da sociedade, para, enfim, empregar esforços para a consolidação de uma identidade genuinamente nacional. Intelectuais de diversas áreas incumbiram-se da missão de pensar sobre os rumos do país. Homens e mulheres reuniram-se em grupos e correntes variadas na tentativa de desvendar a pátria brasileira. Músicos, artistas, literatos, cientistas e políticos, cada um à sua maneira, expressava uma visão sobre a nação e o povo brasileiro.

Nessa corrida, surgiram diferentes opiniões e conceitos acerca do nacionalismo. A literatura e a ciência, caras à nossa pesquisa, tiveram papel preponderante nesse debate. Teorias como o Darwinismo Social, Lamarckismo, Positivismo e Determinismo desempenharam importante papel na tentativa de construção e edificação de um caráter nacional legitimador da sociedade brasileira, direcionadas por uma pequena parte de intelectuais. Muitos intelectuais, pautados pelos ideais dessas teorias, diagnosticaram o Brasil como um país doente, sendo imprescindível a sua cura. Segundo esses "doutores”, a solução encontrava-se no processo de higienização e limpeza social. Aspirava-se por uma "reconstrução" social, uma vez que a mestiçagem, característica indelével da sociedade brasileira, era vista como o principal fator da estagnação do país, sendo, então, necessárias medidas de contenção dos que atrapalhavam o progresso da nação.

Desta forma, o movimento eugênico começava a ganhar espaço no Brasil. Do grego eugen-s, "bem nascido"1, a eugenia buscava por intermédio do conhecimento da hereditariedade, obter uma "melhor reprodução" e um aperfeiçoamento das qualidades inatas dos seres humanos ${ }^{2}$. Ao propor o aprimoramento racial da população, colocava em evidência um debate antigo, recrudescido nas primeiras décadas do século $\mathrm{XX}$ no Brasil: a miscigenação. Com o intuito de superar as mazelas sociais que afligiam o país, alguns médicos e pensadores passaram a questionar a constituição miscigenada da população, pois acreditavam que esse era o grande infortúnio do país. Ao determinar os "tipos" humanos superiores, a eugenia acabava por estabelecer padrões de seleção entre os indivíduos. Termos

\footnotetext{
${ }^{1}$ STEPAN, Nancy Leys. A Hora da Eugenia: Raça, Gênero e Nação na América Latina. Rio de Janeiro, Fiocruz, 2005. p. 9.

${ }^{2}$ GALTON, F. Essays in Eugenics. The EugenicEducationSociety: London, 1909. p. 35.
} 
como disgênicos, inferiores, não-aptos e degenerados foram utilizados para configurar uma sociedade perfeita aos moldes dessa "sábia ciência", pois, acreditava-se que, em nome da razão, ela conseguiria analisar a sociedade e propor alternativas factíveis para os seus impasses.

O desejo de um país perfeito, o anseio pela evolução econômica e cultural, e a ambição pela "ordem e progresso", fizeram com que muitos intelectuais assumissem um posicionamento totalitário. Monteiro Lobato foi um deles. Fez uso da literatura como um instrumento para formular e divulgar suas proposições nacionalistas e eugênicas, tidas por ele como uma "verdade absoluta" e como aptas a classificar e organizar a sociedade brasileira. Embora haja controvérsias quanto ao teor do nacionalismo desse autor, a filiação de Lobato à corrente mais radical da eugenia, defensora de procedimentos severos como, por exemplo, a esterilização, os casamentos seletivos e o controle de indivíduos "disgênicos", é inconteste. Seu desejo de dar educação, ferro e petróleo para o Brasil sempre esteve pautado por premissas e valores científicos.

Assim, exercendo forte influência no debate nacionalista de sua época, Lobato escreveu artigos, contos, crônicas e um único romance, nos quais expunha suas interpretações sociais. O objetivo era denunciar os caminhos tortos seguidos pelo povo brasileiro. Suas observações de homem rico e das letras foram consideradas por muitos como transposição da realidade, tanto que a caricatura do brasileiro, o Jeca Tatu, ainda se faz presente mais de cem anos depois. Contudo, Lobato acabou ficando mais conhecido pelas obras infantis, especialmente pelas aventuras do Sítio do Pica-Pau Amarelo. O autor é relembrado pelas peripécias e malcriações de sua boneca de pano, pelas aventuras de Narizinho e Pedrinho, e pelos saborosos quitutes de Tia Anastácia. No entanto, o movimento que imortalizou e sacralizou Lobato, inserindo-o no pantheon dos grandes nomes das letras pátrias, silenciou sobre o seu único romance, $O$ Choque das Raças. Esta dissertação, uma análise desse tão pouco estudado livro, busca contribuir para romper esse silêncio e desvendar alguns dos sentidos sociais de parte da obra e da vida desse polêmico escritor. Com isso, pretende analisar aspectos da intrincada relação entre ciência, literatura e imprensa no Brasil dos anos 1920.

Não é de hoje que muitos estudiosos têm dedicado especial atenção às obras e a trajetória literária de Monteiro Lobato. Trabalhos de grande fôlego foram (e ainda são) produzidos sobre o pai da Emília. Porém, ainda existe um silêncio constrangido em torno do 
seu romance. Embora novos e interessantes trabalhos tenham surgido sobre essa obra, ainda pouco se fala e se sabe a seu respeito. Por essa razão, dedicamo-nos a tentar entender a sua narrativa, bem como tudo que a envolve.

Abertamente eugenista, $O$ Choque das Raças teve sua primeira publicação no jornal carioca A Manhã, entre os dias cinco de setembro e primeiro de outubro de 1926. O romance não tardou a ganhar forma de livro. Ainda em 1926 foi publicado com algumas modificações e um novo título: O Choque das Raças ou o Presidente Negro: o romance americano de 2228. Nas edições subsequentes, o título $O$ Choque das Raças desapareceu por completo, dando lugar apenas para $O$ Presidente $N^{2} g r{ }^{3}$. A grande aposta desta obra foi na ciência britânica de Galton ${ }^{4}$, no modelo de legislação e sociedade norte-americana, e nas ideias eugênicas reformuladas e adaptadas à realidade brasileira por médicos-sanitarista, alguns amigos próximos de nosso escritor. Monteiro Lobato, inteligentemente, usou suas personagens para ilustrar e tentar convencer seus leitores das razões dessa ciência. É com o ambicioso e jovem Ayrton Lobo, personagem principal e narrador, e na voz firme e convicta de Miss Jane, a própria "bem nascida", que inicia o processo de reconhecimento e convencimento da "sábia ciência". Ao direcionar esta obra ao público adulto, Lobato não precisou medir e conter suas palavras, expôs seus desejos e utopias. Naquele tempo, não constituía grande problema expor publicamente opiniões francamente eugenistas, hoje entendidas como racistas, totalitárias, absurdas e reprováveis de inúmeras formas. Sua visão sobre a sociedade brasileira e o "remédio" que melhor lhe convinha foram lançados aos olhos dos leitores de 1926 diariamente nas páginas de um periódico.

O Choque das Raças conta a história do encontro de Ayrton Lobo com o Professor Benson e sua filha Miss Jane. A partir dessa união e dos conhecimentos adquiridos, o personagem narra as suas transformações pessoais. Inventor da máquina do tempo, o Porviroscópio, Benson introduz seu novo amigo aos conhecimentos eugênicos, e Miss Jane, por intermédio de "recortes anatômicos" temporais, revela a história do choque das raças branca e negra nos Estados Unidos de 2228. Ao contar essa história, a jovem vai aos poucos

\footnotetext{
${ }^{3}$ Logo após a publicação seriada no jornal, o romance ganhou a forma de livro, agora nomeado de $O$ Choque das Raças ou o Presidente Negro. Ao total, essa obra teve três títulos: primeiramente foi denominada de $O$ Choque das Raças, depois de $O$ Choque das Raças ou o Presidente Negro, e mais tarde tornou-se apenas $O$ Presidente Negro. Importante lembrar que todas essas alterações foram feitas pelo próprio autor. Assim sendo, o romance será mencionado neste trabalho de acordo com o seu primeiro título, $O$ Choque das raças, dado que as leituras e análises do romance foram feitas a partir da publicação de 1926 do jornal A Manhã.

${ }^{4}$ Francis Galton (1822-1911), primo de Darwin, cunhou o termo eugenia e suas teorias.

${ }^{5}$ LOBATO, M. O choque das raças. Jornal A Manhã: Rio de Janeiro, 5 de setembro 1926, ano II, n. 215 , p. 5.
} 
demonstrando o quão nefasta foi a inserção do negro naquele país e, consequentemente, no Brasil. Como consequência, passa a ensinar os preceitos básicos da eugenia que justificam o seu posicionamento mais cético em relação ao futuro brasileiro.

Acreditamos que a finalidade deste romance era mais do que apresentar os resultados positivos empreendidos pela eugenia na sociedade norte-americana. A intenção era, principalmente, demonstrar a realidade brasileira e sugerir algumas saídas para o problema da miscigenação no Brasil. Embora grande parte da narrativa se passe no futuro e em outro país, o objetivo do escritor era dialogar sobre o presente brasileiro. Para compreendermos melhor como Lobato fez isso, mergulhamos na narrativa de $O$ Choque das Raças, bem entendido, no texto publicado em A Manhãa, para analisar e entender as propostas apresentadas pelas personagens, bem como a relação entre a história e os acontecimentos do início do século XX.

Assim, as perguntas que inicialmente instigaram essa pesquisa foram: por que Lobato escreveu este romance? Por que ele escolheu lançar seu romance de forma seriada nas folhas de um periódico? Há alguma diferença entre as publicações do jornal e do livro? Qual a relação entre ciência e literatura nos anos 1920? Para responder esses questionamentos, procuramos entender as interlocuções existentes n'O Choque a partir de seu contexto histórico. Para isso, lemos os jornais A Manhã, Correio da Manhã e Gazeta de Notícias ${ }^{6}$, da mesma forma que a Revista do Brasil. As correspondências trocadas ${ }^{7}$ pelo escritor também foram um material fundamental para a pesquisa. Embora apresentem uma "aparente fragilidade" ${ }^{\text {, }}$ essas fontes são passíveis de análises e de diferentes interpretações e nos

\footnotetext{
${ }^{6}$ Para dialogar com $O$ Choque das Raças utilizamos a plataforma digital da Biblioteca Nacional do Brasil, na qual tivemos a oportunidade de trabalhar e pesquisar em alguns jornais do trecho Rio-São Paulo: Gazeta de Notícias; Correio da Manhã; A Noite; ABC; Crítica; A Manhã $O$ Imparcial; O Jornal e O Paiz. Para uma pesquisa mais detalhada, escolhemos os jornais A Manhã, Gazeta de Notícias e Correio da Manhã, primeiro, por estarem disponíveis online, e, segundo, por terem sido jornais de suma importância na sociedade carioca daquele período. Delimitamos, primeiramente, o período entre 1920 a 1929 para pesquisar sobre Monteiro Lobato. No entanto, foi necessária uma restrição temporal entre 1925, 1926 e 1927, para melhor proveito e entendimento dos resultados. Essa decisão foi tomada devido ao grande número de ocorrências dos assuntos. As palavras-chave raça, eugenia, negro, literatura, e feminismo, por exemplo, apresentaram inúmeras ocorrências em cada um dos jornais, sendo que grande parte delas fugiam do tema pesquisado, tomando tempo de pesquisa. Em poucos casos conseguimos extrapolar a pesquisa para períodos anteriores, as quais serão devidamente pontuadas.

${ }^{7}$ Nossa seleção de fontes limita-se às correspondências publicadas por Lobato enquanto vivo e publicadas em $A$ Barca de Bleyre - Tomo I e II; Cartas Escolhidas - Tomo I e II. Para complementar nossas fontes, selecionamos 210 missivas - entre as datas de 1909 a 1946 - pertencentes à biblioteca pessoal de Monteiro Lobato, guardada no Centro de Documentação Cultural Alexandre Eulálio (CEDAE) do Instituto de Estudos e Linguagem (IEL) da Unicamp.

${ }^{8}$ DIAZ, José-Luis. Qual genética para as correspondências. In: Manuscrítica. Revista de Crítica Genética. Trad. Cláudio Hiro e Maria Sílvia IanniBrasalini, nº 15, São Paulo: Humanitas, 2007. p. 122.
} 
ajudaram a compreender um pouco mais a personalidade do escritor, e, principalmente, a interpretar alguns relatos por ele apresentado no romance.

Para tanto, foram necessários alguns cuidados metodológicos, pois muitas dessas cartas vieram a público por intenção e edição do próprio Lobato. Como, então, analisar essas correspondências que foram primeiramente trocadas sem a intenção de publicação, mas que, ao final, foram levadas ao público pela própria vontade dos autores? ${ }^{9}$ Houve algum tipo de seleção, modificação ou todas elas estão ipsis litteris as originais? Teria Lobato deixado de lado alguma correspondência por considerá-la muito pessoal ou polêmica para ir a público? Essas perguntas são pertinentes e necessárias, contudo, não invalidam seu teor histórico e sua importância. Antes de tudo, nos alertam para os cuidados que devem ser tomados para não consideramos estas fontes como verdades acabadas. Portanto, é preciso travar um diálogo entre elas e outros materiais disponíveis daquele período. Desta forma, podemos utilizar esses vestígios históricos como um rico material de pesquisa que nos ajudam a formular hipóteses e sugerem possibilidades de sentidos. Assim, o material não perde o seu valor, mas ganha outras conotações quando em diálogo com outras fontes, nos guiando para terrenos sólidos, nos quais assertivas podem ser elaboradas.

O diálogo com as clássicas biografias de Monteiro Lobato, com as correspondências trocadas com seus conhecidos, e com as reportagens de jornais nos levaram a caminhos até então pouco explorados, ou, até mesmo, ainda não percorridos pela historiografia. Nesse sentido, a pesquisa pode ser definida como um esforço para compreender a obra em sua complexidade, pois, se fez necessário uma interpretação a partir das experiências de Monteiro Lobato e de seus leitores, bem como dos debates relativos à literatura, à ciência eugênica e aos problemas políticos e sociais. A tentativa de nossa pesquisa em historicizar $O$ Choque das

\footnotetext{
${ }^{9}$ De acordo com as nossas fontes, Godofredo Rangel foi o primeiro a pensar em publicar tais cartas, em 1919: "Que ideia sinistra a tua, de publicarmos as minhas cartas! Seria dum grotesco supremo, porque cartas só interessam ao público quando são históricas ou quando oriundas de, ou relativas a grandes personalidades. No nosso caso não há nada disso: não são históricas e nós não passamos de dois pulgões de roseira - eu, um pulgão publicado; você, um pulgão inédito. O interesse que achas nas tais cartas é o interesse da coruja pelas peninhas dos seus filhotes. Formam um álbum de instantâneos da nossa vida. Mas o público quer penas de pavão, plumas de avestruz ou aigrettes de garça não quer peninhas de filhote de coruja. Todos iriam rir-se de nós, além de que estão cheias de maldadezinhas endereçadas a amigos e conhecidos, sobretudo por mim, que tenho a mania de arrasar tudo, a começar por mim mesmo. Não. Varra com a ideia.” (Datada em 26.05.1919 ) Cf.: em LOBATO, Monteiro. A Barca de Gleyre. (t. 1). São Paulo: Brasiliense, 1961. p. 203. Anos depois, Monteiro Lobato acatou a ideia do amigo e começou a datilografar todas as cartas que ainda tinha em casa: "Já tenho todas as cartas passadas à maquina e estou a lê-las de cabo a rabo. Noto muita unidade. Verdadeiras memórias dum novo gênero - escritas a intervalos e sem nem por sombras a menor ideia de que um dia fossem publicadas. Que pedantismo o meu no começo!” (Datadas em 27.10.1943). Cf. Ibidem. p. 360. Essa passagem encontra-se na parte intitulada "Escusatória" do primeiro toma d'A Barca de Gleyre.
} 
Raças se justifica pelo fato de que a leitura no jornal sugere questionamentos diferentes ou até mesmo inexistentes no livro.

Além da leitura no jornal, traçamos, de forma estruturada, alguns dos caminhos percorridos pelas personagens na narrativa, com vista a apreender as possibilidades de sentidos que decorrem da obra. Nesta pesquisa nos deparamos com as múltiplas facetas de Lobato: amigo, estudante, promotor, adido, fazendeiro, literato, publicitário, editor, eugenista, patriota, crítico, futurista, jornalista, marido e pai. Ao longo de todo o trabalho dialogamos com cada uma dessas facetas que se apresentam em momentos marcantes na história do literato. Crédulos da impossibilidade de captar os milhares de "eus" de Lobato, e de escrever uma trajetória linear, pretendemos analisar em especial um lado do literato, aquele cuja repercussão foi ínfima e silenciada, o Lobato eugenista.

Esse lado do escritor é de importância ímpar para a análise deste trabalho, pois acreditamos que para compreender o romance, faz-se necessário também questionar e entender os debates eugênicos de sua época. Por isso, buscamos esmiuçar as questões científicas, as perspectivas literárias e os problemas sociais que informam e dão sentido a obra, caracteristicamente pedagógica, eugenista e nacionalista.

Visto isso, a novidade dessa dissertação está em uma análise da obra no seu lugar primeiro de publicação, o jornal carioca $A$ Manhã. Nossa escolha de ler o romance no periódico está pautada, portanto, no interesse de entender a proposta eugênica por ele apresentada, e, sobretudo, demonstrar que ela não é fruto da imaginação literária de Monteiro Lobato, mas, sim, resultado de suas experiências. Por intermédio de recortes, estabelecemos uma análise temática dos assuntos ali tratados, tais como a miscigenação, os conflitos raciais e o nacionalismo.

Primeiramente, nosso intuito foi analisar, de forma sistemática, a trajetória e produção literária deste autor, com o objetivo de entender o seu amadurecimento intelectual. Buscamos responder e evidenciar as experiências e leituras que informaram Lobato, assim como a sua produção anterior a 1926 que estão em consonância com $O$ Choque. A maneira pela qual ele se apropriou da imprensa para divulgar suas ideias e como se inseriu no meio literário também são questões trabalhadas e problematizadas no primeiro capítulo.

Num segundo momento, mergulhamos na narrativa de $O$ Choque das Raças a fim de questionar e refletir sobre os temas ali apresentados, bem como dialogar com as demais fontes 
históricas, especialmente aquelas ligadas à eugenia. Por meio da leitura do romance no jornal, fizemos analogias com textos e matérias de alguns periódicos. Tentamos reproduzir algumas possibilidades de compreensão analisando as pausas diárias e as reflexões estimuladas pelo autor. Esse exercício proporcionou interpretações até então inexistentes no livro e abriu um horizonte com diferentes sentidos e questionamentos. Assim, o segundo capítulo busca entender mais do que a narrativa do romance, mas também as suas intenções e propostas. Os aspectos propriamente literários, como a lógica narrativa futurista da história e as demais estratégias de Lobato também foram analisados.

Por fim, procuramos decifrar o enigmático desfecho do romance e a sugestão de Lobato para solucionar o problema racial da miscigenação no Brasil. Colocamos em diálogo alguns interlocutores eugenistas a fim de confrontá-los com trechos do romance e entender melhor as sugestões do autor. Deste modo, desejamos trazer à tona novas perspectivas e análises de $O$ Choque das Raças, da mesma forma que tentar acabar com o silêncio que o circunda e retirá-lo do esquecimento, pois entendemos que ele permite discutir pontos importantes do seu tempo. 


\title{
Capítulo 1: Uma trajetória marcada pelo nacionalismo?
}

\begin{abstract}
Dificilmente se encontra um brasileiro com o caráter tão positivo, com uma linguagem tão sincera como a sua, principalmente em se tratando de coisa da Pátria. [...] Acredito que o compreendi perfeitamente e vejo que é um compatriota verdadeiro, porque anela o engrandecimento deste país novo e exuberante de seiva e de vida, que está a pedir homens que o saibam aproveitar. Realmente os verdadeiros atos de patriotismo e de coragem são esses como o seu, que levam o individuo a dizer e escrever coisas que sabe que desagradam, que produzem movimentos de despeito e de revolta, mas que no fím dão resultados práticos. É preciso muita energia para isso e principalmente muita disposição de animo, e é exatamente nesse particular que mais o admiro. Os seus artigos estão pouco conhecidos ainda. A sua pena tem estado um pouco descansada, me parece. Escreva, escreva muito, porque o Brasil precisa de escritores assim que saiba dizer as coisas de um modo claro e positivo, pois os leitores não são, infelizmente, muito fáceis de se levar. ${ }^{10}$
\end{abstract}

Em carta endereçada a Monteiro Lobato em 1922, a escritora Eunice Caldas não busca esconder sua admiração para com o mais novo pupilo das letras brasileiras. Elogios e adjetivos ao escritor paulista parecem-lhe pertinente, dado que a sua escrita foi entendida por ela como verdadeiramente nacionalista e cujo objetivo era apresentar os fatos "desagradáveis" da realidade brasileira. Ao celebrar a "disposição de animo" do escritor em escrever os artigos que compõe o livro Problema Vital $^{11}$, de 1918, a escritora pede para que Lobato siga firme em seu propósito, pois o Brasil precisava, mais do que nunca, de escritores que sabiam dizer as coisas de um modo direto e particular.

Ao exemplo de Eunice Caldas, muitos intelectuais da época encararam o posicionamento de Lobato como nacionalista, como um esforço em prol da pátria e seu desenvolvimento. Num ato de coragem e empenho, o literato retirava o véu das mazelas sociais e colocava à vista as grandes feridas do país. Seus artigos, até então "pouco conhecidos", eram celebrados por esta escritora porque traziam à tona os agentes dos problemas nacionais, apontava o dedo para os culpados das doenças do brasileiro e apresentava uma solução prática: o saneamento básico. Mais do que reverenciar a ação literária lobatiana, Eunice convoca-o a seguir firme em sua trajetória como interlocutor nacionalista que, embora pudesse desagradar inicialmente, traria resultados objetivos e positivos.

\footnotetext{
${ }^{10}$ Carta de Eunice Caldas a Monteiro Lobato, 19.02.1922, CEDAE, MLb 3.2.00272cx5.

${ }^{11}$ Problema Vital é resultado de uma série de artigos publicados no jornal $O$ Estado de S. Paulo, no qual Lobato busca chamar a atenção para os problemas estruturais, sociais e de saúde do país. Nele, o autor denuncia a falta de saneamento básico nas regiões nordeste e centro-oeste do Brasil, e o descaso governamental com as classes mais pobres. A diante, explicaremos melhor essa obra e seu contexto.
} 
Quase cem anos depois, podemos observar que Lobato de fato seguiu os seus conselhos e de tantos outros admiradores e críticos ${ }^{12}$. Continuou a passos firmes seu caminho literário atacando, denunciando, criticando e satirizando os problemas da nação. Assim, encontramos na literatura lobatiana uma trajetória marcada pelo ideal nacional. Suas personagens simbolizam, na grande maioria das vezes, pessoas comuns, e suas histórias representam a realidade brasileira e o desejo de um porvir melhor. Quando nos detemos em seus escritos, encontramos mais do que traços de sua personalidade e anseios, deparamo-nos com uma crítica social e uma ambição em apresentar soluções para o país. No entanto, suas soluções não eram simples de serem aceitas e, por isso, nem sempre foram recebidas de forma passiva. Elas representavam muito mais do que uma vontade nacional, expressavam o desejo de um intelectual e literato, outrora possuidor de terras e posteriormente um homem de negócios.

Situado num torvelinho de emoções nacionalistas onde um grupo seleto de intelectuais brasileiros trazia a tona questionamentos aparentemente inéditos sobre identidade nacional e se via no direito e no dever de "desvendar" nossa cultura, Monteiro Lobato também imaginou uma nação ideal e se utilizou de subterfúgios para tal. A literatura foi a sua maior aliada nessa empreitada e serviu como um meio para discutir, descobrir, inventar e propor uma identidade genuinamente brasileira. Ao desenhar suas histórias, Lobato modelou-as da forma que melhor lhe convinha e a partir de seus ideais de nação. Suas obras literárias demonstram a personalidade crítica e ácida de sua pena e revelam o "mundo encantado"

Seguindo uma linha nacionalista, em 1926, nosso escritor escreveu seu primeiro e único romance, $O$ Choque das Raças. Primeiramente publicado no jornal carioca A Manhã, o romance parece abusar da imaginação quando constrói em sua narrativa uma máquina do tempo que consegue enxergar o futuro através de recortes temporais. Os personagens principais, Professor Benson (o inventor da máquina), Miss Jane (a bela e enigmática filha de Benson) e Ayrton Lobo (narrador e "homem comum"14) estão inseridos e coordenados numa narrativa na qual o leitor é levado a se convencer dos ideais científicos da eugenia, a ciência voltada, entre outros objetivos, para o aprimoramento racial. Considerada por muitos

\footnotetext{
${ }^{12}$ No Centro de Documentação Cultural Alexandre Eulálio (CEDAE) do Instituto de Estudos e Linguagem (IEL) da Unicamp, encontra-se a biblioteca pessoal de Monteiro Lobato na qual encontramos diversas correspondências de leitores a elogiar e agradecer Lobato pelos seus escritos nacionalistas.

${ }^{13}$ Habib, Paula A. B. B. "Eis o Mundo Encantado que Monteiro Lobato Criou”: Raça, Eugenia e Nação. 2003. 225 f. Dissertação (Mestrado) - Universidade Estadual de Campinas, Instituto de Filosofia e Ciências Humanas, UNICAMP. Campinas, São Paulo, 2003.

${ }^{14}$ LOBATO, M. O choque das raças. Jornal A Manhã: Rio de Janeiro, 5 de setembro 1926, ano II, n. 215 , p. 5.
} 
intelectuais e cientistas da época como um caminho para sanear e salvar a nação, sendo por isso considerada nacionalista, a eugenia destinava-se a assegurar a constante melhora da composição hereditária da sociedade, encorajando os indivíduos "adequados" a se reproduzirem e desestimulando a mistura entre raças distintas a fim de evitar a transmissão de caracteres degenerativos às gerações futuras ${ }^{15}$. Assim, de forma clara e objetiva, Lobato constrói uma narrativa permeada de princípios eugênicos, visto como ideais a serem seguidos e apresentados como o grande remédio para o problema racial brasileiro, fruto, no seu modo de entender as coisas da miscigenação. O romance, de forma didática, se utiliza da análise comparativa entre os Estados Unidos do futuro (2228) e o Brasil do presente (1926) para demonstrar as nefastas consequências da mistura de raças. Desta forma, a preocupação em formar o brasileiro eugenicamente forte, capaz de erguer a nação, de construir o país no futuro, livrando-o do elemento negro é questão central no romance, sendo apresentada como urgente e necessária.

Embora a princípio a história pareça fantasiosa, ela incontestavelmente integra o debate social e político brasileiro da época. Sabiamente, Lobato assenhorou-se de uma máquina do tempo para tematizar as incertezas do presente, jogou com as personagens com o intuito de manifestar seu posicionamento frente ao grande debate racial de seu período, e tentou convencer seus leitores de que suas ideias e propostas eram as mais pertinentes. A estratégia narrativa de criação de uma máquina que tudo vê não foi gratuita. Como veremos, ela representava as certezas da ciência, respondia aos questionamentos dos debates científicos sobre o bem da raça e assegurava o caminho certo a ser trilhado.

Assim, em $O$ Choque das Raças, Lobato delineia uma sociedade na qual a miscigenação é tratada como um infortúnio social e cuja solução para os Estados Unidos de 2228 é a esterilização dos negros, uma vez que se configuravam como inferiores e incapazes de aperfeiçoar a nação. Ao argumentar sobre a primazia do sangue puro e colocar como questão as más consequências da mistura de raças, o autor acabava por imaginar e esboçar uma sociedade perfeita de acordo com os moldes eugênicos. Cabia, portanto, cuidar da geração que estava por vir e, para isso, eram necessárias providências no campo da saúde, da educação, da política e da economia. Para Lobato, não bastava investir somente no setor econômico, era necessário também instruir e eugenizar o povo, contribuir para sua educação (eugênica), privilegiar alguns setores, como o industrial e petrolífero. O autor também

\footnotetext{
${ }^{15}$ STEPAN, Nancy Leys. op. cit., p. 9.
} 
defendeu o "industrialismo desenvolvimentista"16 em contraposição ao desenvolvimento agrário - caro à sociedade brasileira daquele período -, pois acreditava no progresso da nação, no "trabalho eficiente como forma de produzir riqueza"17 e no "desenvolvimento econômico como um elemento redentor"18.

Desta forma, convicto em teorias científicas e na eugenia, Lobato formulou hipóteses em seu romance. Foi incisivo e direto em seu posicionamento eugênico nacionalista até o fim, pois acreditava que somente com uma população saudável e bem selecionada, com tipos superiores, o Brasil conseguiria caminhar rumo ao progresso. Caso contrário, continuaria a sofrer as amarguras de um passado miscigenado e degenerado. Contudo, deixou em aberto o final para o leitor retirar suas próprias conclusões. A veia nacionalista da literatura lobatiana é vista por nós como historicamente determinada, pautada e influenciada pelas discussões de sua época. Portanto, entender o Lobato nacionalista é entender sua forma de escrita e seus posicionamentos frente aos debates de seu tempo.

O que levou o menino de Taubaté e o advogado de Areias a abandonar suas terras e se enveredar pelos caminhos tortuosos das letras? Como e por que o jornalismo se tornou um ofício? Como a literatura foi encarada por José Bento Monteiro Lobato? O que o levou a escrever um único romance para adultos em toda a sua carreira literária? Todos esses questionamentos, que dirigem a análise a ser desenvolvida no decorrer deste capítulo, nos parecem estar pautados pelo ideal nacionalista de Lobato, ideal cultivado ao longo de sua jornada como estudante de Direito, como fazendeiro, como escritor, jornalista e editor. A literatura não foi um acaso em sua vida, mas um meio que ele encontrou para dizer as suas "verdades" e "endireitar" o Brasil.

O discurso de progresso da nação de Lobato e de tantos outros intelectuais de sua época passou pelo debate cultural. Compreender a nação significava o mesmo que aceitar a sua cultura. Assim, entender as formas pelas quais Lobato imaginava e compreendia ser o Brasil parece-nos mais interessantes do que simplesmente julgá-lo. Longe de querer reproduzir a literatura que busca isentá-lo de um discurso racista, nossa intenção é entendê-lo

\footnotetext{
16 SANTOS, Elisângela da Silva. Monteiro Lobato e suas seis personagens em busca da nação. 2008. Dissertação (Mestrado) - Faculdade de Filosofia e Ciências, Universidade Estadual Paulista, Marília, 2008. p. 14. Disponível em:<http://www.marilia.unesp.br/Home/PosGraduacao/CienciasSociais/Dissertacoes/santos_es_me_mar.pdf $>$ Acesso em: 06 ago. 2011.

${ }^{17}$ Idem.

${ }^{18}$ Idem.
} 
como sujeito a partir de suas complexidades e de seu contexto social. Almejamos, antes de tudo, depreender os modos de apropriação do sentido de nação por ele ao longo de sua experiência pessoal e jornada literária até a produção do romance $O$ Choque das Raças.

Trilhar os caminhos que o levaram às teorias sanitaristas e eugênicas, e assimilar quais foram as suas influências, nos parece ser uma boa alternativa para entender seu único romance em pormenores e, consequentemente, seu ideal de nacionalismo. Afinal, Lobato foi nacionalista, mas que tipo de nacionalismo ele pregava? Assim, depreender a maneira pela qual esse conceito era aceito por Lobato nos leva, consequentemente, a desvendar $O$ Choque das Raças. Percorrer os "caminhos das pedras" trilhados pelo escritor paulista ao longo de sua trajetória literária nos remete a suas influências científicas e literárias. A questão central desse capítulo é entender a experiência pessoal de Lobato em suas concepções raciais num contexto mais amplo. Buscamos reconhecer os lugares nos quais ele circulava e o que o motivou a escrever o romance $O$ Choque das Raças.

\section{Monteiro Lobato}

Crítico em grau máximo; irônico por excelência; questionador de nascença; insaciável leitor; desmedido orgulhoso: eis Monteiro Lobato cujo sobrenome era confiança. Antes de se constituir como um dos maiores e mais influentes literatos brasileiro, o autor vivenciou experiências que o tornaram uma figura emblemática. Talvez o "mau hábito de dizer o que pens[ava]"19 e a vontade de alcançar a "borboleta de asa de fogo" ${ }^{20}$ o colocou em lugar de destaque no meio jornalístico e literário.

Juntar e organizar todas as peças do grande quebra-cabeça que foi a carreira deste escritor é tarefa difícil, pois, quando adentramos nos arquivos e registros deixados por ele, encontramos múltiplos Lobatos, cada um deles com uma personalidade forte e marcante, com cores vivas e sólidas. O escritor opinava sobre tudo e polemizava com todos. Seu

\footnotetext{
${ }^{19}$ LOBATO, Monteiro. O Brasil às Portas da Maior Crise da sua História. In: LOBATO, Monteiro. Prefácios e Entrevistas. São Paulo: Editora Brasiliense, 1964. p. 136.

20 "Nascemos para perseguir a borboleta de asas de fogo - se a não pegarmos, seremos infelizes; e se a pegarmos, lá se nos queimam as mãos. [...] há uma coisa que nos obriga a partir, a caçar a borboleta, embora certos de que o retorno será na barca de Gleyre. [...] Ser exceção e defendê-la [ser você mesmo] contra todos os assaltos da uniformização: isto me parece a grande coisa. E a tomarmos como programa, é possível que um dia apanhemos a borboleta de asas de fogo - e não tem a mínima importância que nos queime as mãos e a nossa volta seja como a do velho de Gleyre." (Correspondência enviada a Rangel em 15.11.1904. Conferir: LOBATO, M. A Barca de Gleyre... (t. 1), p. 81)
} 
inconformismo, sua mania de transformar o mundo ${ }^{21}$ e sua prepotência em se achar um dos poucos sábios aptos a mudar os rumos do Brasil o fizeram ser amado por muitos e abominado por tantos outros. Certa vez, perguntado quando começara a ter opinião própria respondeu: "'Não sei. Sempre fui tirânico. Eu sempre estava certo. Isso de êrro era com os outros'"22.

José Renato Monteiro Lobato foi um homem de personalidade forte. Deixou marcas por onde passou, cultivou grandes amigos, mas também grandes desavenças. Falou o que muitos receavam, e defendeu com unhas e dentes os seus ideais. Foi fiel aos diferentes Lobatos que existiram dentro de si. Venceu, mas também sofreu. Através de altos e baixos, diferentes linhas de pensamento foram construídas por Lobato. Assim, é por meio dessas linhas, por vezes tortuosas, que encontramos pistas e caminhos que nos fazem questionar e compreender o que levou esse literato a escrever apenas um romance para adultos em sua carreira e cujo tema central é a eugenia. Nosso objetivo é assimilar suas influências e o momento em que Lobato foi tão fortemente marcado pela descoberta da eugenia como uma forma de se pensar e encaminhar soluções para as mazelas da nação. Os modos de apropriação do que era nação e pátria por este escritor nos levam a compreender o programa nacional proposto por ele em $O$ Choque das Raças. Para isso, iremos atrás do menino Juca, nascido em Taubaté no século XIX (mais precisamente em 18 de abril de 1882), filho de José Bento Marcondes Lobato e de Olímpia Monteiro Lobato.

\section{De menino Juca ao fazendeiro do Buquira}

Divergir da opinião e "modus vivendi" geral era uma profissão de fé do literato ${ }^{23}$. Edgar Cavalheiros o define como exagerado e autêntico ${ }^{24}$. Não é para menos se pensarmos que desde pequeno Lobato apresentava-se convicto em suas tomadas de decisões. Aos cinco anos de idade, por exemplo, devido à bengala de seu pai, o menino Juca (apelido carinhoso com o qual seus parentes o chamavam) decide mudar de nome:

- Eu me chamava José Renato [...] Devia ter uns cinco ou seis anos. Meu pai chamava-se José Bento Marcondes Lobato, e tinha uma bengala que era o meu encanto: um unicórnio cor de âmbar, com castão de ouro todo granulado. Bem em

\footnotetext{
${ }^{21}$ AZEVEDO, C. L; CAMARGOS, M.; SACCHETTA, V. Monteiro Lobato: furacão na Botocúndia. $3^{\mathrm{a}}$ ed. São Paulo: editora SENAC São Paulo, 2001.p. 30.

${ }^{22}$ CAVALHEIRO, Edgard. Monteiro Lobato: vida e obra. São Paulo: Companhia Distribuidora de Livro, 1955. p. 23.

${ }^{23}$ Ibidem, p. 65.

${ }^{24}$ Ibidem, p. 102.
} 
cima, no topo do castão, numa parte lisa de metal, estavam as iniciais J.B.M.L. Essas iniciais estragavam-me tudo. Afinal, pensava eu, quando meu pai morrer não poderei usar essa bengala: eu me chamo José Renato; as inicias são J.B.; esse diabo de $\mathrm{B} .{ }^{25}$

Anos mais tarde, o nome de registro era deixado de lado e José Renato apresentava-se ao mundo como José Bento. Mais do que uma homenagem, o nome e a bengala tornaram-se objetos de recordação e herança, uma vez que aos 16 anos de idade, o menino Juca via-se órfão de pai e mãe ${ }^{26}$, e sob a tutela de seu avô materno José Francisco Monteiro, o Visconde de Tremenbé - rico proprietário de terras ${ }^{27}$.

Sua formação escolar se deu no Colégio Paulista de Taubaté e no Colégio Coração de Jesus, ambos da cidade de São Paulo. Já como estudante escreveu seus primeiros textos no jornal estudantil $O$ Guarani sob o pseudônimo de Josbém ${ }^{28}$. Em 1896,

Transferindo-se para a capital paulista, concluiu seus estudos preparatórios no Instituto de Ciências e Letras, onde se destacou por sua participação nos jornais $O$ Patriota e A Pátria e nas sociedades literárias que promoviam debates sobre temas diversos. $^{29}$

Desde cedo Lobato demonstrava o seu talento e afinidade para com as letras. Participou ativamente de grupos estudantis escrevendo textos sob pseudônimos variados. No entanto, sua grande paixão naquele instante era a pintura. Ao terminar os estudos, Lobato desejava matricular-se na Escola de Belas Artes, mas, por imposição do avô, em 1900, aos 18 $\operatorname{anos}^{30}$, acabou ingressando na Academia de Direito na Faculdade do Largo de São Francisco. A pintura foi, talvez, a um dos poucos sonhos que o jovem teve que deixar de lado $^{31}$.

Deste modo, a vida acadêmica do jovem Lobato foi marcada pela pouca importância ao currículo acadêmico e intensa atividade no grêmio literário. Cavalheiro aponta para o seu descaso com a Academia já que o "Direito pouco lhe interessava" ${ }^{32}$, e traz uma de suas confissões: "Fiz, diria mais tarde, ato de presença na Academia, no 'quantum satis' para obter

\footnotetext{
${ }^{25}$ LOBATO, M. A Barca de Gleyre... (t. 1). p. 170.

${ }^{26}$ CAVALHEIRO, Edgard. op. cit., p. 56

${ }^{27}$ AZEVEDO, C. L; CAMARGOS, M.; SACCHETTA, V. Op. Cit., p. 27.

28 FERREIRA, Marieta M. Monteiro Lobato. Cpdoc, p. 2. Disponível em: $<$ http://cpdoc.fgv.br/sites/default/files/verbetes/primeira-republica/LOBATO,\%20Monteiro.pdf > Acesso em fev. 2014.

${ }^{29}$ Idem.

${ }^{30}$ CAVALHEIRO, Edgard. op. cit., p. 6.

${ }^{31}$ AZEVEDO, Carmen L., et al. op. cit., p. 30.

${ }^{32}$ CAVALHEIRO, Edgard. op. cit., p. 62.
} 
diploma"33. Se a monotonia acadêmica lhe trazia insatisfação, a literatura o salvara dos males e preenchia os vazios existenciais do jovem Lobato.

Aos dezoito anos, já escrevia textos literários e se utilizava de formas e neologismos até então pouco empregadas ${ }^{34}$. Em 1900, escreveu o conto Café! Café! no qual ridicularizava a mentalidade obcecada e petrificada dos fazendeiros. Insensível e resistente à ideia de investir em outro mercado que não o café, Lobato compara a mentalidade conservadora do proprietário rural à do caboclo. Apegado e ressentido pelo passado afortunado, o fazendeiro é equiparado pelo autor às

famílias de caboclos que vegetam ao pé dos morros numa choça de palha, cercada de taquara, com um terreirinho, moenda e o chiqueiro e toda a imensidade azul e verde das serras e dos céus a insulá-las da civilização [...]. ${ }^{35}$

Lobato assemelha a mentalidade conservadora do sexagenário proprietário de terras aos modos e hábitos dos caboclos: rude, avesso ao progresso, isolados do mundo civilizado e resistente a mudanças. Essas características rapidamente pinceladas pelo literato em 1900 antecipam algumas perspectivas do caipira que, mais tarde, ganhou a alcunha de Jeca Tatu. Demonstram que a percepção lobatiana para com os mestiços e homens da terra já estava formada e impregnada de uma visão de fora e de homem privilegiado. Enquanto estudante, Lobato já anunciava os temas que o preocupavam e o levariam a produzir uma literatura "engajada", buscando revelar a "mentalidade 'atrasada' do campo, a monocultura, o caboclo e a construção da nacionalidade brasileira",36.

Café! Café! demonstra o quanto Lobato estava atento às questões de seu tempo, afinado literariamente e preocupado com um tipo de progresso (social e econômico), fosse ele no campo ou na cidade. De acordo com o biógrafo Edgar Cavalheiros ${ }^{37}$, a essa altura o estilo lobatiano era nítido, "ironia, sarcasmo, humor, fund[iam-se] na prosa já bem maleável". Lobato, portanto, já era "escritor feito"! ${ }^{38}$. Este artigo nos faz crer que a futura experiência do literato como fazendeiro apenas deu forma literária à figura do Jeca Tatu, uma vez que ela já vinha sendo gestada quatorze anos antes de seu completo nascimento.

\footnotetext{
${ }^{33}$ Ibidem.

${ }^{34}$ CAMPOS, André L. V. A República do Pica Pau Amarelo: uma leitura de Monteiro Lobato. São Paulo: Martins Fontes, 1986. p. 8.

${ }^{35}$ LOBATO, M. Café! Café! In:

${ }^{36}$ CAMPOS, André L. V. op. cit. p. 9. Cidades Mortas. $2^{\mathrm{a}}$ ed. São Paulo: Globo, 2009. p. 171.

37 Edgard Cavalheiro foi um escritor, crítico literário e biógrafo brasileiro. É reconhecido como o mais importante biógrafo de Monteiro Lobato.

${ }^{38}$ CAVALHEIRO, Edgard. op. cit., p. 71.
} 
Até o ano de conclusão do curso de Direito, Lobato e seus amigos do Cenáculo ${ }^{39}$ uma associação literária formada por jovens estudantes ligados por uma "misteriosa afinidade mental" ${ }^{40}$ - dedicaram-se à literatura de forma despretensiosa. O ponto de encontro do grupo era o Minarete, chalezinho amarelo e "toca do Rangel"41. De lá saiam as ideias (não tão) revolucionárias e acabou, mais tarde, servindo de nome ${ }^{42}$ para o jornal no qual os "oito cães" do grupo escreviam semanalmente.

Lobato e seus companheiros de sonhos não alteraram a ordem natural das coisas, nem construíram teorias científicas que revolucionassem os preceitos da física. Começaram a colaborar em um jornal de Pindamonhangaba [...]. Por sugestão de Lobato, o semanário também fora batizado de Minarete, onde os 'oito cães' [...] escreviam com absoluta liberdade, sempre brincando entre si, despidos de qualquer preocupação com o eventual leitor. ${ }^{43}$

O tom despretensioso e fanfarrão dos autores trouxe ao semanário alguns textos de difícil compreensão à população local, pois, como eles próprios assumiam, escreviam só para eles, não se preocupando muito com a interpretação dos demais leitores.

O Minarete foi um jornal sui generis, inteiramente fora dos moldes do jornalismo do interior. Escrevíamos para nós mesmos, para brincar uns com os outros, e os leitores pindamonhangabanos viviam tontos com aquelas incompreensibilidades. ${ }^{44}$

A brincadeira entre amigos deu certo e o Minarete, quatro anos depois, elevou Benjamim à Prefeitura ${ }^{45}$. Mais do que um espaço para bombardear a oposição política, o jornal proporcionou aos amigos do Cenáculo um espaço para grandes façanhas. Lá eles podiam dar espaço a criatividade e escrever o que bem entendiam, especialmente Lobato que chegou a escrever todo o jornal sozinho utilizando inúmeros pseudônimos.

Eu me divertia fazendo de longe o Minarete quase inteiro. Quantos números totalmente escritos por mim - o soneto, os contos, o 'humorismo', o rodapé, o artigo de fundo! Isso me forçava a um grande sortimento de pseudônimos, para dar ao público a impressão de que o jornal dispunha de um exército de colaboradores: Lobatoyewsy, Yewsky, Pascalon o Engraçado, Ruy d'Hã, Helio Bruma, Enoch Vila-

\footnotetext{
${ }^{39}$ Fazia parte do grupo: Ricardo Gonçalves, Godofredo Rangel, Cândido Negreiro, Tito Lívio Brasil, Albino de Camargo, Raul de Freitas, Lino Moreira e Monteiro Lobato. Conferir: LOBATO, M. A Barca de Gleyre...(t. 1), p. 25.

${ }^{40}$ Idem.

${ }^{41}$ Ibidem, p. 21. Alguns dos integrantes moraram no Minarete por diferentes períodos, incluindo Lobato.

42 "Minarete, o jornalzinho que Benjamim Pinheiro manteve em Pindamonhangaba de julho de 1903 a julho de 1907. Benjamim havia se formado em direito e como pretendesse derrubar a situação municipal dominante, tinha necessidade dum aríete demolidor. Discutimos o assunto. Surgiu o problema do nome. [...] 'Pois dê ao jornal o nome de Minarete, sugeri, no primeiro numero explicaremos aos povos o que é minarete - aquelas esguias torres das gentes islâmicas, de cujo topo, ao cair da tarde, os muezins convocam os fiéis á prece. Um jornal é um minarete de cujo topo o jornalista dá milho às galinhas da assinatura e venda avulsa. Fica muito bem esse nome e é nome que não está estragado." (Ibidem, p. 28)

43 AZEVEDO, Carmen L., et al. op. cit., p. 42.

${ }^{44}$ LOBATO, M. A Barca de Gleyre... (t. 1). p. 31.

${ }^{45}$ Ibidem, p. 28.
} 
Lobos, Matinho Dias, B. do Pinto, Osvaldo, P., N., Yan Sada Yako, Mem Bugalho, She, Antão de Magalhães, Nero de Aguiar, Bertoldo, Marcos Twein, Olga de Lima, etc. etc. E todos lá do Cenáculo nele escrevíamos. ${ }^{46}$

O Minarete abriu portas para todos do Cenáculo. Lobato, por exemplo, no mesmo período chegou a colaborar nos jornais Combatente e Povo, ambos de Caçapava (SP) ${ }^{47}$. Esse período de experiência de escritor/jornalista foi importante porque trouxe a Lobato toda a maturidade e perspicácia que foi colocada em prática tempos depois. Todo o conhecimento adquirido nos tempos de estudante foi profícuo ao escritor que veio a sacudir o mercado editorial brasileiro anos mais tarde.

1904. Acabava o ano e a vida acadêmica de Lobato. Com um diploma em mãos precisava regressar a sua terra natal e deixar para trás os amigos e as descontrações literárias. Voltar aos costumes e ócio interioranos parecia-lhe um exílio, e nada daquilo satisfazia seu espírito irrequieto e ávido pelo conhecimento.

Aqui no exílio a modorra é um mal ambiente que derruba até os mais fortes. Exílio, Rangel, pura verdade! Saltar da libérrima vida estudantina de S. Paulo e cair neste convencionalismo de aldeia, com trabalhos forçados... Sinto-me rodeado de conspiradores; todos tramam a meu achatamento. ${ }^{48}$

Bem adaptado à vida de metrópole, o tempo ocioso era-lhe um castigo. Reclamava que o ar da fazenda o tornava "burro" e que morar no interior era uma espécie de "suicídio mental" ${ }^{49}$. No entanto, foi durante o seu período de exílio que conheceu Purezinha, sua futura e eterna esposa. Em 1907, foi nomeado promotor público na cidade de Areias, onde viveu até 1911. No ano seguinte casou-se e, como alternativa para sair de lá e juntar dinheiro, começou a colaborar para grandes jornais de São Paulo e Rio de Janeiro. Passou a remeter desenhos e caricaturas para a revista Fon-Fon ${ }^{50}$ e textos para A Tribuna de Santos, O Estado de S. Paulo $^{51}$, e a Gazeta de Notícias.

Aos poucos Lobato começava a adentrar o mundo da imprensa brasileira e a garantir espaço para seus trabalhos. Escrever para os periódicos era uma forma de "neutralizar" sua insatisfação pessoal, profissional, e, além disso, um meio de também conseguir uma renda extra. A literatura, o jornalismo e as correspondências com os amigos eram as formas pelas

\footnotetext{
${ }^{46}$ Ibidem, p. 29

47 AZEVEDO, Carmen L., et al. op. cit., p. 46. Alguns desses textos foram mais tarde publicados no livro Cidades Mortas, no qual o autor busca descrever o marasmo do interior brasileiro e a ineficiência do aparelho estatal.

${ }^{48}$ LOBATO, M. A Barca de Gleyre... (t. 1). p. 84.

${ }^{49}$ Ibidem, p. 96.

${ }^{50}$ Ibidem, p. 255.

${ }^{51}$ Ibidem, p. 250. Inicialmente, Lobato enviava textos traduzidos do jornal australiano Weekly Times.
} 
quais travava contato com o mundo externo, já que em Areias "nem o gancho dum Shakespeare tirava sequer um título de drama" ${ }^{52}$. Acreditava que a criatividade do escritor advinha do meio no qual vivia: "Meio pífio, artista pífio - obra d'arte pífia" "53. Deste modo, somente o Rio de Janeiro produzia arte de prestígio, e ele, residente do interior, estaria condenado a "ser água panada" 54 , sem serventia alguma.

Entretanto, o período de morada em Areias não foi tão ruim e improdutivo como lamuriava Lobato. Além de colaborar com a Tribuna e outros periódicos e revistas, escreveu diversos contos que mais tarde (1919) foram reunidos e publicados no livro Cidades Mortas. Resultado das observações e experiências do autor nessa cidade, o conjunto de contos busca apresentar os motivos da decadência e atraso da região. A cidade fictícia Itaoca é representada como à margem da civilização, onde todos os grandes fazendeiros ricos da região haviam se mudado para o Rio de Janeiro, São Paulo e Europa. De acordo com o escritor, subsistiam apenas uma pequena quantidade de

caboclos opilados, de esclerótica biliosa, inermes, incapazes de fecundar a terra, incapazes de abandonar a querência, verdadeiros vegetais de carne que não florescem nem frutificam - a fauna cadavérica de última fase a roer os derradeiros capões de café escondidos nos grotões.

Restava apenas o "projeto de gente", o caboclo doente, desprovido de qualquer ímpeto de mudança. "Verdadeiros vegetais" que nada produziam, o caipira do conto Cidades Mortas (1906) era incompatível com o projeto social e nacionalista em fases de construção de Monteiro Lobato. Ele se adaptava ao meio igual a bicho, se conformava com a penúria e dela não mais saia porque não agia e se contentava com o minguado. Como podemos ver, a noção do caboclo como sujeito inferior e improdutivo, apesar de tímida (em comparação com o Jeca), já era uma ideia consolidada na mentalidade do escritor. No entanto, a imagem negativa do caboclo ganhou contornos mais nítidos e concretos quando Lobato se mudou para a fazenda do Buquira e se tornou o "Lobato-fazendeiro".

Assim, com a morte de seu avô, o Visconde de Tremembé, em 1911, Lobato transferese para a Serra da Mantiqueira para tornar-se um proprietário de terras. Agora, como administrador da fazenda herdada, não tinha mais tempo para dedicar-se à literatura como anteriormente, pois precisava cuidar das atividades e dos problemas do campo. Confessava ao amigo Godofredo Rangel que faltava-lhe tempo para escrever e ler, e que as obrigações como

\footnotetext{
52 Ibidem, p. 176.

${ }^{53}$ Idem.

${ }^{54}$ Ibidem, p. 177.
} 
proprietário e administrador ocupavam todo o seu tempo. $\mathrm{O}$ contato direto que ele travava com os caboclos e com as atividades do campo levaram-no a recrudescer suas hipóteses quanto aos problemas da fazenda e, consequentemente, da nação. Conforme ia se convencendo de que o caboclo era o grande obstáculo do desenvolvimento das colheitas, Lobato começava a elaborar a ideia de um conto no qual denunciaria suas inquietações. Relata a Godofredo Rangel que andava pensando na possibilidade de escrever um conto, "o Porrigo decalvans, em que considerarei o caboclo um piolho da terra, uma praga da terra" $"$.

Assim, à medida que cresciam as dificuldades econômicas e que se estendiam as queimadas nos campos e plantações, Lobato ia formulando e fortalecendo suas teorias sobre o homem da terra. A convivência diária com os caboclos alertava-o para o desrespeito destes homens para com a natureza que lhes fornecia alimentos, abrigo e subsistência. Revoltado com o descaso, queimadas e prejuízos provocados pelos caboclos, no ano de 1914 escreveu a crônica Uma Velha Praga, um violento protesto em forma de denúncia, enviado para a seção "Queixas e Reclamações" d'O Estado de S. Paulo, um dos mais importantes jornais da época. Deslocada da seção para o corpo principal do jornal, "a matéria é estampada com destaque em 12 de novembro de 1914 e alcança inesperada repercussão" ${ }^{" 56}$. A partir desse momento, Lobato ganhava voz e espaço na impressa nacional. O seu "estágio agrícola"57, embora causticante e aparentemente distante do universo literário, criou dentro de si "uma verdadeira usina de projetos literários" ${ }^{\text {"58 }}$, pois o meio que o cercava era sua grande fonte de inspiração.

\section{O Piolho da Terra}

Qual a causa da renitente calamidade? [...] A nossa montanha é vítima de um parasita, um piolho da terra, peculiar ao solo brasileiro como o Argas o é aos galinheiros ou o Sarcoptes mutans à perna das aves domésticas. Poderíamos, analogicamente, classificá-lo entre as variedades do Porrico decalvans, o parasita do couro cabeludo produtor da 'pelada', pois que onde assiste se vai despojando a terra de sua coma vegetal até cair em norma de decrepitude, nua e descalvada. [...]

Este funesto parasita da terra é o CABOCLO, espécie de homem baldio, seminômade, inadaptável à civilização, mas que vive à beira dela na penumbra das zonas fronteiriças. À medida que o progresso vem chegando com a via férrea, o italiano, o arado, a valorização da propriedade, vai ele refugindo em silêncio, com o seu cachorro, o seu pilão, a pica-pau e o isqueiro, de modo a sempre conservar-se

\footnotetext{
${ }^{55}$ Ibidem, p. 327. (correspondência datada em 09/0/1912)

${ }^{56}$ AZEVEDO, Carmen L., et al. op. cit., p. 56.

${ }^{57}$ LOBATO, M. Faz Vinte e Cinco Anos... In: LOBATO, M. Prefácios e Entrevistas... p. 188. Entrevista dada a Silveira Peixoto para "Vamos Ler".

${ }^{58}$ AZEVEDO, Carmen L., et al. op. cit., p. 54.
} 
fronteiriço, mudo e sorna. Encoscorado numa rotina de pedra, recua para não adaptar-se. 59

O caboclo e toda a sua geração são retratados em Uma Velha Praga como inadaptáveis à civilização, avessos ao desenvolvimento, uma "quantidade negativa" 60 que se alastrava pelos campos do país fugindo do progresso e civilização, causando a desordem natural. Nesta crônica, encontramos um grito aguerrido do Lobato fazendeiro cansado dos prejuízos causados pelo piolho da terra. Ao compará-lo a pragas, o escritor constrói uma imagem animalesca do caboclo, semelhante a dos parasitas que somente usufruem do seu meio e nada oferecem ou dão em troca. Contudo, o mais interessante a se observar é que essa imagem primitiva do homem da terra já estava bem estruturada na mentalidade do escritor anos antes (1912) de ser passado para o papel. Em carta ao amigo Rangel, Lobato comenta:

Já te expus a minha teoria do caboclo, como o piolho da terra, o Porrigo decalvans das terras virgens? Ando a pensar em coisas com base nessa teoria, um livro profundamente nacional, sem laivos nem sequer remotos de qualquer influência europeia. [...] Se não sair, será mais um casulo que seca sem dar borboleta. ${ }^{61}$

Em 1912, dois anos antes de escrever o manifesto contra o caboclo (Urupês), o escritor e então fazendeiro já havia formulado estereótipos a seu respeito. Se nos esforçarmos um pouco, lembraremos que nos contos Café!Café e Cidades Mortas, escritos respectivamente em 1900 e 1906, a figura do caboclo é introduzida. Embora sua imagem seja superficial e pouco delineada, Lobato já o apresentava como impenetrável e contrário à prosperidade e à civilização. Essa imagem negativa do homem da terra, já delineada na mentalidade do escritor, ganhou uma configuração mais nítida quando Lobato se tornou proprietário de terras. A experiência de fazendeiro fez aflorar ainda mais sua visão negativa sobre os caipiras. No entanto, foi apenas em 1914 que o escritor viu-se convicto de suas teorias sobre o caboclo parasita e, portanto, pronto para atacá-lo.

A aparição e o deslocamento do artigo Uma Velha Praga para o corpo central do jornal dava um lugar de importância ao tema ali discutido, e, principalmente, levava ao conhecimento dos leitores de $O$ Estado de S. Paulo a figura emblemática de Monteiro Lobato. Até então desconhecido do grande público leitor, Lobato passará de um simples escritor/fazendeiro a um literato/jornalista de pena forte. Embora já tivesse colaborado com outros jornais, ele ainda não havia se apresentado e assinado seus textos diretamente, nem escrito de forma tão causticante. Isso demonstra como Lobato tornou-se literato e como a

\footnotetext{
${ }^{59}$ LOBATO, M. Velha Praga. In: Urupês. $37^{\mathrm{a}}$ ed. São Paulo: Editora Brasiliense, 1994. p. 87-88.

${ }^{60}$ Idem.

${ }^{61}$ LOBATO, M. Barca de Gleyre... (t. 1). p. 326 (correspondência de 07.02.1912)
} 
imprensa teve papel fundamental nesse processo. Percebe-se que a partir de agora Lobato começa a produzir e publicar artigos próprios na imprensa de forma regular e sua alcunha passa a ser conhecida pelo público letrado.

Consciente da estreita relação entre jornalismo e literatura ${ }^{62}$, marca indelével daquele momento, o escritor paulista se aproveitou da boa maré ocasionada por seu artigo. Para termos uma noção do seu impacto, Uma Velha Praga chegou a ser publicada em 60 jornais em pouco tempo! $!^{63}$ Isso demonstra a boa receptividade do texto e como Lobato soube fazer uso de seu sucesso, explorando o mercado jornalístico e tornando seu nome conhecido. Nas primeiras décadas do século XX, os periódicos eram os centros para onde se convergiam escritores de diversos estilos e filiações, e lugar de discussão de ideias artísticas, literárias e também nacionalistas ${ }^{64}$. O jornal, portanto, dava condições para a existência do literato ${ }^{65}$, até então sem espaço significativo de divulgação. Olavo Bilac, por exemplo, testemunhava a importância do jornalismo para a literatura:

É mesmo o único meio do escritor se fazer ler. O meio da ação nos falharia absolutamente se não fosse o jornal - porque o livro ainda não é coisa que se compre no Brasil, como uma necessidade. ${ }^{66}$

Bilac foi um dos grandes nomes do meio literário que, apesar de suas ácidas críticas ao jornalismo, em especial sobre os efeitos nocivos dele para a literatura, não relutou em fazer uso dos periódicos para publicar incontáveis crônicas e garantir assim o seu prestígio como homem de letras. É fácil encontrar seus textos em diferentes jornais e revistas, com a Gazeta de Notícias e Kosmos, pois escrevia diariamente para cada um deles. Os jornais abrangiam grande parte das camadas populares e intelectuais da sociedade e por isso era o meio mais fácil para se atingir o público. O jornalismo tinha importância ímpar no Brasil semianalfabeto e pobre. Desta forma, de 1914 a 1918, Lobato passou a estampar as folhas dos periódicos paulistas e cariocas. Passou também a expor suas ideias sobre o país e sua composição

\footnotetext{
${ }^{62}$ A maioria dos literatos começava e desenvolvia sua carreira em jornais e revistas da época, pois eram os periódicos que tornavam os escritores conhecidos.

${ }^{63}$ MARTINS, Milena R. Quem conta um conto... aumenta, diminui, modifica: o processo de escrita do conto lobatiano. Campinas, SP, 1998. Tese (Mestrado), Universidade Estadual de Campinas, Instituto de Estudos da Linguagem. p. 13.

${ }^{64}$ Idem.

${ }^{65}$ Ibidem, p. 21.

${ }^{66}$ BILAC, O. apud MARTINS, MARTINS, Milena R. op. cit., p. 13.
} 
racial $^{67}$. Quer como jornalista quer como literato, pôs-se a condenar o caboclo e as misturas raciais.

Ao apresentar uma interpretação negativa do mestiço encarnado no caboclo, Lobato fazia eco a uma visão bastante difundida socialmente. Pois as primeiras décadas do século XX no Brasil estavam marcadas por um intenso debate racial. Falar sobre raça e miscigenação não era novidade. Talvez sua visão contrária a misturas raciais e pessimista sobre o caipira assomados ao tom e caráter denunciativo e crítico de suas palavras tenham sido novos naquela época. De qualquer forma, as teorias racialistas e racistas vindas da Europa e dos Estados Unidos estavam muito em voga e ganhavam cada vez mais espaço nos meios intelectuais e acadêmicos brasileiros ${ }^{68}$. Além disso, a maciça presença de negros e mestiços nas ruas, nos lares (como trabalhadores domésticos), na casa de detenção e de correção faziam das relações raciais aspecto cotidiano e tenso. Estava em jogo a busca de uma nação perfeita do ponto de vista social e hereditário, e para isso fazia-se necessário compreender sua composição racial. Monteiro Lobato, antenado a esses debates, colocou-se em posição de destaque e passou a julgar o caboclo como o grande mal da sociedade.

Assim, um mês depois da publicação de Uma Velha Praga, Lobato publica o conto Urupês. O caboclo aqui ganha nome e sobrenome, e sua análise parece mais profunda e cruel. Lobato não mede palavras para instituir o mestiço como o causador dos seus problemas, e, mais do que isso, dos problemas nacionais. Em missiva a Rangel em outubro de 1914, desabafa:

\begin{abstract}
Atualmente estou em luta contra quatro piolhos desta ordem - 'agregados' aqui das terras. Persigo-os, quero ver se os estalo nas unhas. Meu grande incêndio de matas deste ano a eles o devo. Estudo-os. Começo a acompanhar o piolho desde o estado de lêndea, no útero duma cabocla suja por fora e inçada de superstições por dentro. Nasce por mãos duma negra parteira, senhora de rezas mágicas de macumba. Cresce no chão batido das choças e do terreiro, entre galinhas, leitões e cachorrinho, com uma eterna lombriga de ranho pendurada no nariz. Vê-lo virar menino, tomar o pito e a faca de ponta, impregnar-se do vocabulário e da 'sabedoria' paterna, provar a primeira pinga, queimar o primeiro mato, matar com a pica-pau a primeira rolinha, casar e passar a piolhar a serra nas redondezas do sítio onde nasceu, até que a morte o recolha. Conta a obra de pilhagem e depredação do caboclo. A caça nativa que ele destrói, as velhas árvores que ele derruba, as extensões de matas lindas que ele reduz
\end{abstract}

\footnotetext{
${ }^{67}$ QUAGLINO, Maria Ana. Noções de Raça e Eugenia em Monteiro Lobato: vida e obra. In: XI Encontro Regional de História ANPUH-RJ - Democracia e Conflito. 2004. Disponível em: $<$ http://www.google.com.br/url?sa=t\&rct=j\&q=\&esrc=s\&source=web\&cd=1\&ved=0CFMQFjAA\&url=http $\% 3$ A $\% 2 \mathrm{~F} \% 2 \mathrm{Fwww} . \mathrm{rj}$.anpuh.org\%2Fresources \%2Frj\%2FAnais\%2F2004\%2FSimposios\%2520Tematicos\%2FMari a\%2520Ana\%2520Quaglino.doc\&ei=16UNUOmPGKPi0QH2usjWAw\&usg=AFQjCNG2OjH54AVU4c6HBwE 0AdS2BP4fpA > Acesso em: julho de 2012. p. 6.

${ }^{68}$ No terceiro capítulo nos deteremos mais e melhor nesse debate a fim de entender as formas de assimilação dessas teorias.
} 
a carvão. [...] Queima toda uma face de morra para plantar um litro de milho. E assim por diante. [...] O piolho, afugentado, vai parasitar um chão virgem mais adiante. $^{69}$

Lobato demonstra a Rangel os motivos que o levavam a lutar contra "o piolho da terra”. Essa imagem construída por ele é, aliás, um tanto quanto interessante, primeiro, porque traz novamente a ideia do caboclo como um bicho, um parasita que se aproveita dos bens que a terra oferece. O caipira só extrai e nada dá em troca. Desfruta dos benefícios do solo fértil e em troca transforma-o em "cinzeiro", queimando tudo, não reaproveitando ou produzindo algo sequer. Da mesma forma que um animal, segue seu instinto e passa a viver e reproduzir o mesmo ciclo desastroso das queimadas e da degradação ambiental. No lugar de cuidar e cultivar a terra para melhor proveito e cultivo, afugenta-se a "parasitar um chão virgem mais adiante", pois o trabalho não é seu aliado.

É certo que as queimadas do período de agosto a dezembro de 1914 acenderam a revolta de Lobato, no entanto, não podemos dizer que foi a partir dela que ele configurou a imagem negativa do caboclo, pois, como visto, ela já estava formada há muito tempo. Assim, nas palavras de Carmen Lúcia de Azevedo, Márcia Camargo e Vladimir Sacchetta, Uma Velha Praga "foi a faísca que faria alastrar o fogo da revolta lobatiana"70, pois o casulo de outrora virara borboleta que voara pelo Brasil de ponta a ponta, arrebanhando milhares de prosélitos. A partir daquele momento, com a boa aceitação e repercussão do texto, Lobato não mais se intimidou em escrever sobre o parasita da terra sob os holofotes da imprensa.

O conto Urupês ganhava vida e era apresentado ao mundo no dia 23 de dezembro daquele mesmo ano. A imagem do caboclo desprovido de força de vontade apresentada anteriormente foi ampliada nessa história.

A 15 de Novembro, troca-se um trono vitalício pela cadeira quadrienal. O país
bestifica-se ante o inopinado da mudança. O caboclo não dá pela coisa. [...] O
caboclo continua de cócoras, a modorrar... Nada o esperta. Nenhuma ferrotoada o
põe de pé. Social, como individualmente, em todos os atos da vida, Jeca, antes de
agir, acocora-se. Jeca Tatu é um piraquara do Paraíba, maravilhoso epítome de carne
onde se resumem todas as características da espécie.

A preguiça e a resignação do caboclo eram tão grandes que nem mesmo a Proclamação da República fora capaz de fazê-lo sair da inércia ou de mudar seu pensamento. O "sentimento de pátria lhe [era] desconhecido", não tinha sequer uma noção do país em que

\footnotetext{
${ }^{69}$ LOBATO, M. Barca de Gleyre... (t. 1). p. 363-364.

${ }^{70}$ AZEVEDO, Carmen L., et al. op. cit., p. 58.

${ }^{71}$ LOBATO, M. Urupês. In: Urupês. $37^{\mathrm{a}}$ ed. São Paulo: Editora Brasiliense, 1994. p. 92.
} 
vivia, e, por isso, de acordo com Lobato, nada o faria despertar para a vida. Faltava-lhe patriotismo e ação. Acentuadas a inferioridade e ignorância do homem do interior, o autor decide, então, batizá-lo de Jeca Tatu e desmistificá-lo. Personagem-símbolo das obras lobatiana, o Jeca aparece agora como o "sacerdote da Grande Lei do Menor Esforço"72, de cócoras e feio. "Pobre Jeca Tatu! Com o és bonito no romance e feio na realidade!"73. Ao alegar que era preciso enxergar o verdadeiro caboclo, o autor quis descrever como era "sua vida, seus hábitos, suas superstições e sua casa" ${ }^{74}$. Desenvolvia, assim, uma alegoria do homem do campo, símbolo do atraso nacional. Seu objetivo era, através da sua experiência como fazendeiro, demonstrar e confirmar suas teorias e modelos estabelecidos para a formação da nação brasileira.

\begin{abstract}
A nossa literatura é fabricada nas cidades por sujeitos que não penetram nos campos de medo dos carrapatos. E se por acaso um deles se atreve e faz uma 'entrada', a novidade do cenário embota-lhe a visão, atrapalha-o, e ele, por comodidade, entra a ver o velho caboclo romântico já cristalizado - e até vê caipirinhas cor de jambo, como o Fagundes Varela. O meio de curar esses homens de letras é retificar-lhes a visão. Como? Dando a cada um, ao Coelho, à Júlia Lopes uma fazenda na serra para que a administrem. Se eu não houvesse virado fazendeiro e visto como é realmente a coisa, o mais certo era estar lá na cidade a perpetuar a visão erradíssima do nosso homem rural. O romantismo indianista foi todo ele uma tremenda mentira; e morto o indianismo, os nossos escritores o que fizeram foi mudar a ostra. Conservaram a casca... em vez de índio, caboclo. ${ }^{75}$
\end{abstract}

Ora, era necessário mostrar o quanto a visão dos homens e mulheres das letras estava errada e enviesada. Sua experiência como fazendeiro dava-lhe respaldos para construir a figura do homem do interior como rudimentar e malicioso, pois tinha o certificado da convivência, resultado de sua observação. Ao ver de perto as mazelas causadas pelo caboclo, Lobato não pensou duas vezes em criticar todos aqueles que o romantizavam, assim como o faziam com os indígenas. Ao dar vida ao Jeca, o escritor pretendia enterrar o indianismo romântico da literatura regional ${ }^{76}$, pois acreditava ser preciso matar o caboclo fantasioso que evoluiu dos índios de Alencar e chegou até Coelho Neto ${ }^{77}$. Lobato trazia sua experiência da vida real com o propósito político e social de informar os leitores: os caboclos estariam estragando os campos e, com isso, a nação.

O dissabor de Lobato com o caipira fica cada vez mais evidente quando lemos suas correspondências e nos detemos em seus escritos. Ele assume para seu cunhado Heitor que,

\footnotetext{
${ }^{72}$ Ibidem, p. 93.

${ }^{73}$ Ibidem, p. 92.

${ }^{74}$ HABIB, Paula A. B. B. op. cit., p. 28.

${ }^{75}$ LOBATO, M. Barca de Gleyre...(t. 1). p. 364-365.

${ }^{76}$ AZEVEDO, Carmen L., et al. op. cit., p. 60.

${ }^{77}$ LOBATO, M. Barca de Gleyre...(t. 1). p. 364.
} 
depois que se meteu a literato "por forças das noites compridas na roça",78, pôs-se a escrever tragédias. Relacionava sua postura à incapacidade dos literatos brasileiros em "matar uma mosca, por sentimentalismo mulheril”. Essa visão romântica da vida não lhe parecia ser a mais aprazível e afirmava que sua "literatura não é de imaginação",79, era, pois, "pensamento descritivo" ${ }^{80}$. Não criava, mas, sim, copiava da vida real, do natural. Assim, dizia apresentar o caboclo tal como ele era, sem exageros e máscaras e que talvez por isso conseguia tanto seguidores e admiradores.

O inesperado sucesso desses artigos gerou polêmica pelo país de norte a sul. Reproduzidos em sessenta jornais ${ }^{81}$ e reunidos mais tarde em livro, os textos chamavam a atenção dos leitores não só para os problemas do campo, mas, também, para os problemas sociais do país. Ao denunciar de forma virulenta o Jeca Tatu e rebaixá-lo à categoria de animal inferior (ele é um tatu, mora na toca, e é inferior até mesmo no reino dos animais ${ }^{82}$ ), Lobato acabava por denunciar o descaso do governo com a formação social, cultural e econômica nacional. Como era de se esperar, acalorados debates surgiram em seguida. Muitos se recusavam a aceitar o diagnóstico pessimista do literato, o que acabou gerando algumas versões redentoras do povo, como o Mané Chique-Chique, de Ildefonso Albano, e o Juca Leão, de Rocha Pombo ${ }^{83}$.

Antítese do Jeca, o Mané Chique-Chique é proliferador, trabalhador e feliz. Não se "acorrenta a inércia pelo cego fatalismo, nem deixa cair a biboca de capé" ${ }^{84}$. Sua versão cearense ri, canta, ama, vive e chora. Ele reivindicava seu lugar no trabalho, sua postura de homem de ação, e "desacocorava" o Jeca Tatu ${ }^{85}$. Idelfonso Albano revelava o Brasil por intermédio de sua personagem, uma "rocha viva da nacionalidade", logo, extremo oposto do Jeca. Essa visão heróica de Chique-Chique se complementava com a de Juca Leão que era

\footnotetext{
${ }^{78}$ LOBATO, M. Cartas escolhidas. São Paulo: Brasiliense, 1959. v. 1. p. 155. (carta de 17.8.1916)

${ }^{79}$ LOBATO, M. apud AZEVEDO, Carmen L., et al. op. cit., p. 50.

${ }^{80}$ Idem.

81 "A Velha Praga não cessa a peregrinação. Já foi transcrita em sessenta jornais, conforme me informa o Sinésio Passos, redator dum jornal de Guaratinguetá. Acho muito, e se o consigo é para frisar a ignorância em que andamos de nós mesmo: a menor revelação da verdade faz o público arregalar o olho." Correspondência de 16/01/1915. Conferir: LOBATO, M. Barca de Gleyre. (t. 2). São Paulo: Brasiliense, 1961. p. 10.

${ }^{82}$ CASSAL, Sueli Aparecida T. B. O Brasil visto verticalmente: uma constelação chamada Monteiro Lobato. 2003. 269 f. Tese (doutorado) - Universidade Federal do Rio Grande do Sul, UFRGS. Porto Alegre, Rio Grande do Sul, 2003. p. 51.

${ }^{83}$ AZEVEDO, Carmen L., et al. op. cit., p. 61.

${ }^{84}$ Livros Novos: "Jeca Tatu e Mané Chique-Chique". Gazeta de Notícias. Rio de Janeiro, Ano XLV, n. 88, 1920, p. 4. Disponível em: <http://memoria.bn.br/DocReader/docreader.aspx?bib=103730_05\&PagFis=734> Acesso em dez. 2015.

${ }^{85}$ Idem.
} 
uma "figura cheia de virtudes e de nenhum defeito" 86 . Curioso notar que estes personagens foram esquecidos, tendo sido o Jeca o único a sobreviver, resistindo ao efeito devastador do tempo.

Essas personagens surgiram como interlocutoras daqueles contrários ao posicionamento de Lobato e sua caricatura da população rural. No entanto, independente dos burburinhos que surgiam, aumentavam os convites e possibilidades de trabalho para Lobato, e o "seu envolvimento com a produção intelectual e literária cresc[ia] na medida inversamente proporcional ao [seu] interesse pela fazenda, em franco declínio" ${ }^{87}$.

O "estágio agrícola" do nosso literato durou cerca de seis anos (1911 a 1917), tempo suficiente para ele se certificar de que o campo não era o seu lugar e firmar seu nome na imprensa. Lobato chegou a colaborar intensamente para grandes revistas e periódicos da época. A Revista do Brasil, O Estado de S. Paulo, Correio Paulistano, Tribuna, dentre outros, não paravam de pedir-lhe textos. Astuto, nosso escritor não perdia a oportunidade de fazer crescer seus tributos financeiros e, mais ainda, sua reputação como escritor/jornalista.

Dizes bem quanto á disseminação do nome por intermédio de outras folhas. Isto é
como eleitorado. Escrevendo no Estado, consigo um corpo de 80 mil leitores, dada a
circulação de 40 mil do jornal e atribuindo a média de 2 leitores para cada exemplar.
Ora, se me introduzir num jornal do Rio de tiragem equivalente, já consigo dobrar o
meu eleitorado. Ser lido por 200 mil pessoas é ir gravando o nome - e isso ajuda. Já
tirei a prova. Indo ontem falar com um médico do Instituto Paulista, Enjolras
Vampré, recebeu-me ele de dois modos: o primeiro, frio, indiferente, o modo de
receber aos que na vida não passam de números - mas depois que dei o meu nome, a
cara do homem clareou. [...] Veja você como para o mundo tem peso um nome que
assina artigos no jornal. A gente passa de servo da gleba á classe de senhores.

Lobato, a julgar pelo não disfarçado orgulho expresso nesse trecho, via a si mesmo como pessoa destacada, um senhor pertencente à classe de pessoa distinta. O termo, nunca é demais lembrar, servia para designar, ao longo do século XIX, os grandes senhores de terras e de gente. Assim, Lobato se via como uma versão moderna da classe senhorial oitocentista. Consciente dos significados sociais de se ter um nome público e escrever para jornais de grande vulto, Lobato aproveitou-se do espaço conquistado para produzir artigos que evidenciassem os problemas nacionais. Sabia que uma parte dos leitores compunha uma elite intelectualizada e que estava falando, principalmente, para eles. Isso fica evidente quando ele

\footnotetext{
${ }^{86}$ MORAES, Pedro R. B. de. O Jeca e a cozinheira: raça e racismo em Monteiro Lobato. Revista de Sociologia e Politica. n. 8, 1997. p. 104. Disponível em: <http://revistas.ufpr.br/rsp/article/view/39322>. Acesso em agosto 2015.

${ }^{87}$ AZEVEDO, Carmen L., et al. op. cit., p. 61.

${ }^{88}$ LOBATO, M. Barca de Gleyre... (t. 2). p. 20. (correspondência de 12/02/1915)
} 
declara: "Se os meus caboclos soubessem ler e soubessem como sou feroz..." ${ }^{\text {. }}$. Lobato não escrevia para os caboclos, mas, sim, para uma camada mais privilegiada da sociedade. Sua intenção era transparecer a "verdadeira" realidade dos homens da terra, parasitas e destruidores de plantações. A "preocupação em desvendar a realidade de um Brasil desconhecido" 90 , levou Lobato a colocar o dedo na ferida dos homens e mulheres brasileiros. Ao invés de apresentar um país bonito por natureza, escolheu desvelar as mazelas que assombravam a sociedade. O tom crítico e ácido apresentado em textos anteriores continuou presente e tornou-se sua marca registrada.

Lobato foi insistente em argumentar contra os estrangeirismos absorvidos e estimulados na cultura da época. Protestou e denunciou o imitativismo que impregnava a mentalidade brasileira, feliz em reproduzir de forma fajuta o modelo europeu. Em 1917, n'O Saci-Pererê: o resultado de um inquérito, criticava:

Tendes sede? No bar só há chopps, grogs, cocktails, vermouths. Tendes fome? Dãovos sandwichs de pão alemão e queijo suíço. Lá apita um trem: é a Inglesa. Tomais um bonde: é a Light. Cobra-vos a passagem um italiano. Desceis num cinema: É Íris, Odeon, Bijou. Começa a projeção: é uma tolice francesa de Pathé ou uma calamidade da Itália. ${ }^{91}$

Nacionalista à sua maneira, o literato foi contra toda e qualquer forma de apropriação estrangeira. Acreditava que o folclore, a cultura genuinamente nacional, seria capaz de trazer à tona a essência do povo brasileiro, tão almejada pela elite intelectual nas primeiras décadas do século XX. Julgava que devíamos nos espelhar nas civilizações mais evoluídas, mas jamais copiá-las a ponto de vivermos a cultura do outro.

O posicionamento crítico de Monteiro Lobato também estava permeado de aparentes contradições. Como entender a defesa de uma cultura folclorista em oposição ao homem mestiço do interior? Como analisar posturas tão díspares, mas complementares para Lobato? Qual era o Brasil a ser valorizado se parte importante do povo era o avesso do progresso? Essas aparentes contradições irão permanecer durante toda a trajetória literária lobatiana e nos levam a compreender alguns dos sentidos do nacionalismo eugenista almejado pelo escritor que terá o seu ápice em 1926. Lobato até aqui parece ser contrário a toda e qualquer forma de mistura racial. O caboclo representa não somente o resultado da hibridização entre brancos e indígenas, mas também o branco com negro. Acreditava que a miscigenação corrompia todas

\footnotetext{
${ }^{89}$ LOBATO, M. Cartas escolhidas...(v. 1). p. 155.

${ }^{90}$ AZEVEDO, Carmen L., et al. op. cit., p. 63.

${ }^{91}$ LOBATO, M. apud AZEVEDO, Carmen L., et al. op. cit., p. 63.
} 
as raças envolvidas, pois retirava os bons caracteres dos indígenas e dos negros, e, principalmente, sucumbia e deteriorava o sangue do branco.

Percebendo a urgência em se resgatar o elemento nativo nacional, Lobato propõe a busca das origens culturais, dos mitos e das lendas populares através de um inquérito. Assim, em 1917, nas páginas do Estadinho (suplemento de O Estado de S. Paulo), Lobato organizou um questionário e um concurso de pintura sobre a figura folclórica do Saci ${ }^{92}$. Propôs também aos leitores que enviassem cartas relatando tudo que soubessem sobre o menino negro de cachimbo na boca e uma perna só. A repercussão foi tão grande que Saci-Pererê: resultado de um inquérito tornou-se o primeiro livro publicado do autor, em 1918. Não assinou a obra, pois reconhecia não ter escrito uma única só palavra, apenas organizado os textos enviados pelos leitores. Lobato, então, por intermédio de um "molecote negro"93 questionava a apropriação dos costumes europeus insistentemente copiados pela burguesia brasileira, e buscava despertar a consciência pela cultura nacional.

Essa obra era fruto (mais uma vez) do investimento de Lobato em busca de um despertar de consciência nacional. Acreditava que conhecer as lendas, os mitos e fábulas brasileiras, traria à tona a cultura nacional adormecida. Diferentemente de outros intelectuais que acreditavam na apropriação do elemento estrangeiro como forma de acelerar o desenvolvimento cultural do Brasil, Lobato buscava colaborar para o debate nacionalista fundamentando-se nas características regionalistas do país. Aqui podemos ver que a suposta contradição do autor não se fundamenta, pois ele buscava descobrir o elemento nacional a partir da valorização da cultura brasileira e não do homem.

A Revista do Brasil, por exemplo, continha um manifesto-programa nacional muito parecido com as ideias desse literato e foi, portanto, uma das grandes disseminadoras dos contos e ideais pregados por ele. Desde o seu surgimento em 1916, o literato participou ativamente enviando contos e pequenos textos. Por insistência de Plínio Barreto ${ }^{94}$, então diretor do periódico, reuniu todos os contos publicados na Revista e em outros periódicos da época e organizou o livro Urupês. Lançado em 1918, a coletânea possui quatorze contos nos

\footnotetext{
${ }^{92}$ SANTOS, Elisângela da Silva. op. cit., p. 18.

93 AZEVEDO, Carmen L., et al. op. cit., p. 74.

94 "Em meio á produção pseudônima, foram vindo esses contos, muitos dos quais também eram desabafos. Publique-os em periódicos de maior vulto, como a 'Revista do Brasil', então dirigida por Plínio Barreto e Pinheiro Junior. Mas eu não alimentava a intenção de fazer livro. A primeira ideia de reunir aqueles contos em volume foi-me dada pelo Plínio. 'Publique!' disse ele. 'Conheço o público. Todos vão gostar'..." (LOBATO, M. Entrevista com Silveira Peixoto, da "Gazeta-Magazine”, In: LOBATO, M. Prefácios e Entrevistas... p. 172)
} 
quais busca denunciar os problemas e atrasos do Brasil. Para demonstrar sua tese, Lobato ressalta que uma parcela significativa de sua população não fazia a menor questão do progresso. Aqui, o Jeca Tatu aparece como a caricatura do povo brasileiro, bonito no romance e feio na realidade.

Da literatura dos contos de Lobato, emerge a imagem de um país devastado, roído, vicejando no atraso e na falta de caráter nacional. Na impossibilidade de aprofundarse na psicologia humana, Lobato foi um exímio caricaturista, talhando seus personagens à foice, com o corrosivo da água-forte. O conto lhe serviu para a fixação de tipos. No seu regionalismo não há lugar para o saudosismo. ${ }^{95}$

O livro Urupês, além de potencializar a figura negativa do homem do campo, traz o Jeca como estereótipo do povo brasileiro. Patife; piolho da terra; Porrigo decalvans; parasita; homem baldio; seminômade; inadaptável à civilização; fronteiriço; mudo; sorna; fazedor de sapezeiros; quantidade negativa; incapaz de evolução; feio; indolente; piraquara; epítome da carne; impenetrável ao progresso; preguiçoso; sacerdote da Grande Lei do Menor Esforço; soturno; morto-vivo; carrapato; lêndea; berne; erva-de-passarinho; mata-pau... Ora, o Jeca era um "parasita infestado de parasitas" 96 , que só atrapalhava o progresso da nação. É curioso observa-se que a desvalorização do caboclo somada à metáfora do parasita alcançava o povo brasileiro. Agora não é só o Jeca que é retratado de forma negativa, mas, sim, toda a "Jecatatuásia"97.

É importante compreendermos que por detrás da caricatura do caboclo existiam interesses de um fazendeiro lesado com as constantes queimadas, o que acabou marcando o lugar de fala de Lobato, no qual se evidencia mais a faceta do Lobato fazendeiro do que escritor $^{98}$. Assim, sem conseguir se aprofundar nas questões humanas e psicológicas do caipira, o autor denunciou apenas aquilo que o incomodava enquanto latifundiário: a improdutividade do trabalho do caboclo que estava diretamente relacionada à noção de atraso social e cultural ${ }^{99}$.

Rudimentar e malicioso, o Jeca é retratado como apático e o Brasil como um país em ruínas. O caipira é visto como um pobre, sem teto e marginalizado, o qual dependia da boa

\footnotetext{
${ }^{95}$ CASSAL, Sueli A. T. B. op. cit., p. 47.

96 Ibidem, p. 52.

${ }^{97}$ Ibidem, p. 137. Segundo Lobato, o "Brasil é uma Jecatatuásia de oito milhões de quilômetros quadrados." Cf.: LOBATO, M. Barca de Gleyre... (t. 2). p. 40.

${ }^{98}$ GOUVÊA, Luzimar Goulart. O homem caipira nas obras de Lobato e de Mazzaropi: a construção de um imaginário. Dissertação (mestrado) - Universidade Estadual de Campinhas, Instituto de Estudos da Linguagem UNICAMP. Campinas, São Paulo, 2001. p. 62.

${ }^{99}$ CAMPOS, André L. V. op. cit., p. 21.
} 
vontade dos senhores de terras para sobreviver. Era um agregado, e assim mantinha uma relação de parceria com os proprietários rurais, pois escolhia mear as terras no lugar de se submeter aos mandos e desmandos de seus superiores. Deste modo, os homens da terra eram vistos pelos patrões como preguiçosos e seminômades, que a qualquer sintoma de incompatibilidade podiam ser "tocados"100. A fúria de Lobato e o seu desejo de vingança acabaram por gerar uma visão simplista e superficial do caboclo. Criava uma imagem estereotipada, eivada de preconceitos do autor e com muitos sentidos.

\begin{abstract}
A recusa pelo trabalho e a opção pela parceria e meação, frente à necessidade premente dos fazendeiros de café, certamente fizeram gerar nestes últimos uma revolta cega contra aqueles que ousavam arrostar o seu poder de senhores. A pecha de preguiçosos e vadios recaiu sobre aquela população livre. Caipiras, então, são vistos como atrasados e refratários à evolução. É interessante notar que, naquele momento [período escravocrata], além dos escravos, os caipiras eram a única outra mão-de-obra disponível. Em suma, eles eram os trabalhadores nacionais, mas foram rejeitados pela classe patronal, chegando a haver mesmo uma recusa incondicional [...] desses trabalhadores. ${ }^{101}$
\end{abstract}

A imagem do Jeca Tatu foi, então, considerada como a mais contundente representação do homem caipira para uma parcela da população letrada daquele momento e continuou por muitos anos sendo o sinônimo do homem brasileiro. Para consolidar ainda mais a figura do Jeca e de seu autor, no dia 20 de março de 1919, no Teatro Lírico do Rio de Janeiro, Rui Barbosa, então candidato à presidência da República pela segunda vez, começava sua conferência perguntando:

Conheceis, porventura, o Jeca Tatu, do Urupês, de Monteiro Lobato, o admirável escritor paulista? Tivestes algum dia, ocasião de ver surgir, debaixo desse pincel de uma arte rara, na sua rudeza, aquele tipo de uma raça, que, 'entre as formadoras da nossa nacionalidade', se perpetua 'a vegetar, de cócoras, incapaz de evolução e impenetrável ao progresso? ${ }^{102}$

Na longa conferência, o candidato à presidência destrinçava a teoria do piolho da terra apresentada em Urupês e confirmava os inúmeros adjetivos dispensados ao caboclo e, consequentemente, a sociedade brasileira. Após o discurso de Rui Barbosa, crescia o prestígio da obra e a curiosidade em torna dela ${ }^{103}$. O reconhecimento do Ministro da Justiça não passara

\footnotetext{
${ }^{100}$ Em Uma Velha Praga Lobato sentencia um curioso preceito: "ao caboclo, toca-se. Toca-se, como se toca um cachorro importuno, ou uma galinha que vareja pela sala. E tão afeito anda ele a isso, que é comum ouvi-lo dizer: "Se eu fizer tal coisa, o senhor não me toca?" (LOBATO, M. Urupês... p. 89)

${ }^{101}$ GOUVÊA, Luzimar G. op. cit., p. 30.

102 BARBOSA, Rui. A questão social e política no Brasil. CDU, 869.0(81) Lobato 7.07. p. 1.

103 "Os meus 'Urupês' foram-se. O raio do Rui me criou uma revoada cá no escritório, é um sair de livros sem conta. Restam-me 150 de 7.000 tiradas de julho para cá, e a $4^{\text {a }}$ edição faz-se a galope. Sorte bêsta!" (correspondência enviada a Lima Barreto. Conferir: CAVALHEIROS, E. A correspondência entre Monteiro Lobato e Lima Barreto. Os cadernos de cultura: Ministério da Educação e Cultura, 1955. p. 37)
} 
despercebido, e, embora já tivesse certo prestígio ${ }^{104}$, Urupês era agora uma das obras literárias mais comentadas e publicadas no país.

O discurso do Ruy foi um pé de vento que deu nos Urupês. Não ficou um para remédio, dos 7.000! Estou apressando a quarta edição, que irá do oitavo ao décimo segundo milheiro. Tiro-as agora aos quatro mil e isto antes de um ano, hein? O livro assanhou a taba - e agora, com o discurso do Cacique-Mór, vai subir que nem foguete. $^{105}$

Fenômeno nacional, Urupês e Monteiro Lobato alçaram voo. Ainda que a intenção primeira do autor não fosse angariar tantos seguidores e sim desabafar e se vingar daquele que o prejudicara, Uma Velha Praga e Urupês abriram portas preciosas para seu autor. Durante o tempo em que cuidava de negócios aparentemente distantes e incompatíveis ao mundo das letras, Lobato ia "construindo dentro de si uma verdadeira usina de projetos literários"106. De fato, o meio havia lhe influenciado e servido como fonte de inspiração. Com tantas portas abertas, Lobato toma a decisão de vender a fazenda e investir num sonho antigo: abrir uma editora. Assim, o período de 1914 a 1918 foi marcante para a história de Lobato como literato e jornalista, pois a partir desse momento ele conseguiu ganhar espaço na impressa e se tornou literato de renome, um verdadeiro sucesso de crítica e de vendas.

\title{
0 renascimento do Jeca Tatu
}

\begin{abstract}
Nas diversas cruzadas e causas públicas em que se engajaria ao longo da vida, Monteiro Lobato sonhava transformar o Brasil em uma nação próspera [...]. Tornouse apóstolo das campanhas de saneamento, defendendo a aplicação da ciência médica - em lugar das rezas de bezendeiras - contra as doenças e parasitas que infestavam o organismo da população de baixa renda. E consciente da importância da comunicação e poder da palavra escrita, expandiu o mercado livreiro até as fronteiras mais remotas. Para Lobato, o atraso do país só seria superado pelo trabalho racional e aposta na modernização. ${ }^{107}$
\end{abstract}

O Lobato escritor, publicista, amigo, fazendeiro e intelectual esteve atrelado, mesmo que de forma ambígua, às lutas nacionalistas em prol de solucionar as questões sociais,

\footnotetext{
104 "Os Urupês vão se vendendo melhor do que esperei, e neste andar tenho de vir com a segunda edição dentro de três ou quatro semanas. Há livrarias que no espaço duma semana repetiram o pedido três vezes, e como os jornais ainda nada disseram, julgo muito promissora essa circinstância." (LOBATO, M. A Barca de Gleyre... (t. 2). p. 173. (correspondência de 08/07/1918)

105 LOBATO, M. A Barca de Gleyre... (t. 1).p. 194. (correspondência de 20/04/1919)

${ }^{106}$ AZEVEDO, Carmen L., et al. op. cit., p. 54.

107 AZEVEDO apud QUELUZ, Gilson Leandro. Eugenias Modernistas: O Presidente Negro de Monteiro Lobato e a República 3000 de Menotti Del Picchia. Revista Tecnologia e Sociedade, Curitiba, n. 2, $1^{\circ}$ semestre de 2006. Disponível em: <http://revistas.utfpr.edu.br/ct/tecnologiaesociedade/index.php/000/article/viewArticle/39> Acesso em: set. 2010.
} 
políticas e econômicas que assolavam o Brasil no início do século XX. Contudo, suas soluções estavam longe da imagem "idílica e conciliadora"108 que lhe foi construída tempos depois. Lobato, no mesmo ano em que publicou Urupês, livro no qual construiu a imagem do caboclo indolente, de cócoras, indiferente às mudanças e incapaz de evolução, toma conhecimento da Campanha Sanitarista. O contato com as teorias desse movimento o levou a repensar a imagem pessimista e negativa que havia construído sobre Jeca Tatu.

Liderada pelos médicos-sanitaristas Belisário Pena e Arthur Neiva, a Campanha PróSaneamento foi resultado do relatório da expedição que durante quatro anos (1912-916) fez pesquisas pelo interior das regiões centro-oeste e nordeste do Brasil. Neste relatório, os cientistas demonstravam ser precárias as condições de moradia, higiene e vida dos sertanejos. $\mathrm{O}$ volume já começa apresentando os dados concernentes às regiões percorridas. Informa e descreve o processo de desertificação no interior do país ocasionado pelos nativos. "Desmente o patriotismo garganteiro"109 que enaltece a riqueza da terra, e relata as perceptíveis áreas de pobre produtividade. Analisa meticulosamente a flora e fauna das regiões cursadas, e estuda as causas das doenças que infestam os homens dos sertões ${ }^{110}$.

Ao final, constatam que o grande problema do país era a falta de saneamento básico, e denunciam as más condições de vida e saúde da população rural. As casas são apresentadas pelos médicos-sanitaristas como reais focos de proliferação dos elementos patogênicos:

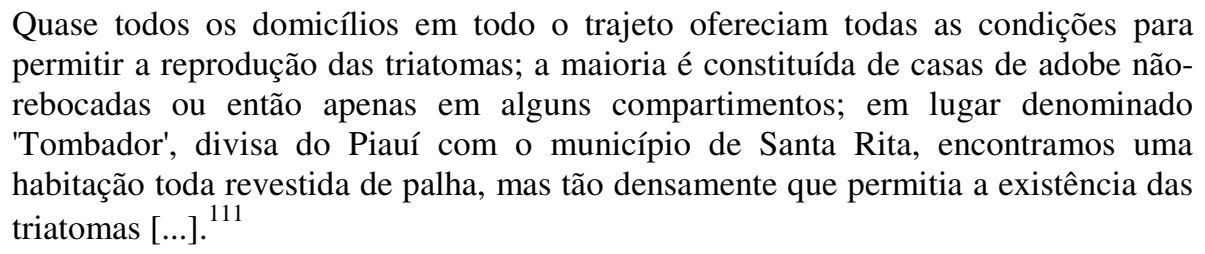

O problema de saúde do país não era só um problema da medicina, era também social. As epidemias que assolavam especialmente o nordeste eram reflexos da falta de estrutura sanitária e apoio governamental. A partir dessa expedição, Pena e Neiva passaram a defender a campanha de saneamento básico como primordial para a redenção social, moral e econômica da nação ${ }^{112}$. Com forte impacto sobre as elites intelectuais, o relatório dos

\footnotetext{
${ }^{108}$ Habib, Paula A. B. B. op. cit., p. 18.

109 NEIVA, Artur; PENA, Belisário. Viagem científica pelo norte da Bahia, sudoeste de Pernambuco, sul do Piaíu e de norte a sul de Goiás. Ed. fac-similar. Brasília: Senado Federal, 1999. p. V

${ }^{110}$ Doença de Chagas, bócio, febre amarela, ancilostomose, esquistossomose, malária, tuberculose, bouba, lepra, leishmaniose, moléstia de Heine Medin, difteria, filariose, carbúnculo e desinteria: são algumas das doenças estudadas pelos médicos nessa excursão.

${ }^{111}$ NEIVA, Artur; PENA, Belisário. op. cit., p. X.

${ }^{112}$ Cf.: <http://www.museudavida.fiocruz.br/brasiliana/cgi/cgilua.exe/sys/start.htm?infoid=157\&sid=5>
} 
médicos-sanitaristas incentivou, em 1918, à criação da Liga Pró-Saneamento do Brasil. O sertanejo seguia como um ser inferior e incapaz. A diferença, ou novidade, era a causa e, por conseguinte, a solução do problema.

Começava, assim, a ganhar força a teoria de que o caipira não era improdutivo e preguiçoso devido à raça, fruto da miscigenação, mas, sim, graças ao desamparo governamental e à falta de medidas profiláticas. A miséria e as doenças endêmicas, consequência da falta de saneamento, "passaram a assumir o primeiro plano como fatores determinantes" ${ }^{113}$ da inferioridade de homens e mulheres do campo.

A experiência que Lobato adquiriu enquanto fazendeiro em conjunto com as leituras filosóficas e científicas ${ }^{114}$ sobre raça trouxeram-lhe concepções racistas acerca da realidade do caboclo, levando-o a considerá-lo um pobre doente sem cura. Mais tarde, com acesso às pesquisas empreendidas pelos médicos-sanitaristas, Lobato se convenceu de que a tragédia maior estava nas doenças e que a melhor solução era o saneamento dos sertões ${ }^{115}$ e a "modernização das relações de trabalho"116. De agora em diante, o Jeca passa a ser compreendido por seu "pai" como consequência de uma infeliz causa. A doença era o que impedia o desenvolvimento de suas potencialidades física e mental, incapacitando-o para o trabalho eficiente. Assim, ciente que a indolência do Jeca não era mais uma característica congênita do homem da terra, e sim uma consequência da péssima realidade sanitária do país. E foi assim que Lobato pede desculpas ao Jeca e passa a polemizar sobre a questão do saneamento básico no Brasil ${ }^{117}$.

Em 1918, na segunda edição de Urupês, Lobato acrescenta uma Explicação necessária:

Entra nesse livro de contos uma caricatura que o não é, Urupês. Ela veio solver o tremendo problema batismal. E aqui aproveito o lance para implorar perdão ao pobre Jeca. Eu ignorava que eras assim, meu Tatu, por motivo de doença. Hoje é com

\footnotetext{
113 STANCIK, Marco Antônio. Os Jecas do Literato e do Cientista: Movimento Eugênico, Higienismo e Racismo na Primeira República. UEPG Ci. Hum.,Ci. Soc. Apl., Letras e Artes, Ponta Grossa, n. 13 (1), p. 45-62, jun. 2005. p. 50. Disponível em: <http://www.revistas2.uepg.br/index.php/humanas/article/viewFile/535/536> Acesso em: ago. 2011.

${ }^{114}$ De acordo com Edgard Cavalheiros, "o destino pusera-lhe nas mãos um livro do Le Bon”, Spencer, Comte, Darwin e tantos outros autores que o fizeram se enveredar pelos campos do evolucionismo e positivismo. Conferir: CAVALHEIRO, E. Monteiro Lobato: vida e obra... p. 77-78.

115 STANCIK, Marco Antônio. op. cit., p. 50.

${ }^{116}$ CAMPOS, André L. V. op. cit. p. 35.

${ }^{117}$ CHIARELLI, Tadeu. Um Jeca nos Vernissages: Monteiro Lobato e o desejo de uma Arte Nacional no Brasil. São Paulo: Editora da Universidade de São Paulo, 1995. p. 219.
} 
piedade infinita que te encara quem, naquele tempo, só via em ti um mamporreio de marca. Perdoas? ${ }^{118}$

Lobato ressuscita o Jeca e pede-lhe desculpas, pois ele não era assim, estava assim ${ }^{119}$. Sua inaptidão era reflexo de suas doenças até então ignoradas pelo escritor. Assim, na quarta edição de Urupês, de 1919, Monteiro Lobato inclui outra nota de pedido de desculpas:

\begin{abstract}
Cumpre-me, todavia, implorar perdão ao pobre Jeca. Eu ignorava que eras assim, meu caro Tatu, por motivo de doenças tremendas. Está provado que tens no sangue e nas tripas um jardim zoológico da pior espécie. É essa bicharia cruel que te faz papudo, feio, molenga, inerte. Tens culpa disso? Claro que não. Assim, é com piedade infinita que te encara hoje o ignorantão que outrora só via em ti mamparra e ruindade. Perdoa-me, pois, pobre opilado, e crê no que te digo ao ouvido: és tudo isso que eu disse, sem tirar uma vírgula, mas inda és a melhor coisa que há no país. Os outros, que falam francês, dançam o tango, pitam havanas e, senhores de tudo, te mantêm nessa gehenna [sic] dolorosa, para que possam viver folgada à custa do teu penoso trabalho, esses, caro Jeca, têm na alma todas as verminoses que tu só tens no corpo. Doente por doente, antes como tu, doente só do corpo... ${ }^{120}$
\end{abstract}

Esse pedido de desculpas revela como Lobato acolheu as ideias vindas do movimento sanitarista. Demonstra que o literato enxergou que havia acertado nos sintomas, mas errara na causa e, assim, na condenação do Jeca como incurável e destinado ao fracasso. Esse olhar misto apresentado nos prefácios das novas edições evidencia a nova forma de julgamento do literato para com a sua personagem. Mais do que isso, exprime a nova noção de raça e mistura racial adotada por ele. As ideias pregadas por esse movimento não versavam apenas sobre os meios profiláticos estruturais, mas também sobre a composição racial do país. Desta forma, parece que encontramos um Lobato mais brando que começa a vislumbrar no Jeca curado uma forma de progresso e símbolo nacional, porque "doente por doente, antes tu, doente só do corpo" e com sinal de cura.

Mais do que acolher os resultados da expedição sanitária de Arthur Neiva, Lobato, naquele momento, também passa a ter conhecimento das teorias eugênicas ${ }^{121}$. Mescladas uma na outra, eugenia e sanitarismo trazem uma nova percepção do caboclo e da miscigenação. Começa a vislumbrar na mistura racial um meio de aprimoramento racial, de dissolução dos elementos negativos dos "tipos humanos" e de branqueamento da população. O caboclo agora

\footnotetext{
${ }^{118}$ LOBATO, M. Urupês... p. 86.

${ }^{119}$ LOBATO, M. Problema Vital. In: LOBATO, M. Mr. Slang e o Brasil e Problema Vital. $11^{\text {a }}$ ed. São Paulo: Ed. Brasiliense, 1964. p. 22.

${ }^{120}$ MONTEIRO, L. apud GOUVÊA, L. op. cit., p. 66-67.

${ }^{121}$ No prefácio do livro Bio-perspectivas do médico sanitarista Renato Kehl, Lobato conta como ele se deparou com as ciências eugenia e o sanitarismo: "Vim a conhecer Renato Kehl no início de minha vida literária, certo ano em que, numa série de artigos de jornal [1918], me pus a entender de saneamento." Cf.: LOBATO, M. Prefácio. In. KEHL, Renato. Bio-Perspectivas: dicionário filosófico. Rio de Janeiro: Livraria Francisco Alves, 1938. p. 17.
} 
é encarado como apenas doente do corpo e passível de cura. Bastava tomar os remédios certos e voltaria a fazer parte da sociedade como um ente produtivo e ativo.

Agora o Jeca se tornava merecedor de desculpas e digno de ser reparado. Como se pode observar, Monteiro Lobato preconizou e incorporou o discurso por melhores condições de higiene sanitária como um dos caminhos para a restauração nacional. Além de sua preocupação nacionalista, Lobato ao retratar o "antes e depois" do Jeca, traz uma reflexão sobre o "homem brasileiro, ou, mais exatamente, sobre o homem trabalhador do campo"122. Vieira de Campos, por exemplo, acredita que a ressurreição do personagem traz a nova noção de Lobato quanto aos problemas sociais e raciais. Ao "deslocar o problema do atraso do Brasil de uma questão de raça para o campo da maior eficiência do trabalho" ${ }^{123}$, Lobato estaria por propor a intervenção da ciência médica atrelada a uma nova visão de organização e disciplina do trabalho ${ }^{124}$.

Paula Habib afirma que o pedido de desculpas ao Jeca representa mais do que uma autocrítica, "podemos ler também a comunhão entre Lobato e as teorias raciais que estavam em voga no Brasil"125. Teorias como o Evolucionismo, Darwinismo, Lamarckismo, Positivismo, Sanitarismo e Eugenia, eram alguns dos pensamentos científicos que vigoravam à época que influenciaram Monteiro Lobato a elaborar suas próprias concepções e suposições sobre o assunto. Ora, mais do que assimilar tais ideias, Lobato as incorporava de forma gradativa e as reproduzia em suas obras literárias.

No mesmo ano da publicação da segunda edição de Urupês, 1918, Lobato escreveu uma série de artigos para o jornal $O$ Estado de S. Paulo. Nestas publicações são contadas histórias que englobam os dados e a realidade apresentada nos relatórios da expedição sanitarista de Belisário Penna e Arthur Neiva. Assim, denominava o Brasil como "dezessete

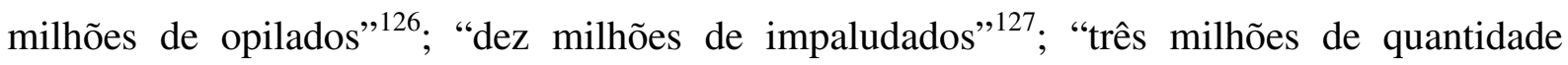
negativas, incapazes de produzir"128 e condenadas a serem "viveiros do parasito letal"129. O escritor paulista criticava a inação e a negligência das autoridades políticas e dos literatos das

\footnotetext{
${ }^{122}$ CAMPOS, André L. V. op. cit. p. 35.

123 Ibidem, p. 42.

${ }^{124}$ Ibidem, p 40.

${ }^{125}$ HABIB, Paula A. B. B. op. cit., p. 33.

${ }^{126}$ LOBATO, M. Problema Vital... p. 231.

${ }^{127}$ Ibidem, 248.

${ }^{128}$ Ibidem, p. 240.

${ }^{129}$ Idem.
} 
capitais que "bizantinizam sobre a colocação de pronomes e outras maravilhas" ${ }^{130}$, mentindo sobre a realidade dos brasileiros do interior do país. Acreditava que havíamos falido "como povo, como raça - e falimos moral, intelectual e fisicamente" ${ }^{\text {"131 }}$. No entanto, ainda restava uma solução: dar higiene à população do campo ${ }^{132}$.

O nosso problema, verificado que foi o mau estado da população nativa, é simples e uno: sanear. Para sanear é forçoso, preliminarmente, convencermos o país da sua doença; e em seguida fazer dessa ideia o programa de todos os governos, a ideia de todos os particulares. ${ }^{133}$

Entender o problema nacional para, em seguida, solucioná-lo: essa era a grande questão para Lobato. Sanear os sertões era mais do que necessário, era uma ação nacionalista e impreterível, pois acreditava que patriota era somente aquele que cumpria com "o seu dever, e trabalha[va], e produz[ia] riqueza material ou mental, e funciona[va] como a silenciosa madrepora[sic] na construção econômica e ética do seu país"134. A partir destas crônicas, Lobato explicitou o que entendia ser patriotismo. Exprimiu que sua preocupação maior não era mais com a pessoa do caboclo, personificado no Jeca, nem com os homens e mulheres dos sertões. Sua preocupação recaia, antes de tudo, nas questões financeiras, no lucro, na economia e no progresso nacional ${ }^{135}$. Ou seja, saneado e curado das mazelas que o assolavam, o caipira poderia trabalhar e contribuir para o aperfeiçoamento do país. Ser patriota, para Lobato, era "ser trabalhador e um trabalhador consciente de seu deveres e direitos, de forma a apresentar resultados para a economia e a política nacional”,136

Ao se redimir com o Jeca no conto Urupês, em o Problema Vital, o escritor transforma o medíocre caboclo e o torna em um opulento coronel. Proprietário de uma grande fazenda - e que fazenda! A mais moderna da região, Jeca progredia fisicamente e, principalmente, financeiramente. Em matéria de saúde, quem poderia ganhar do mais novo coronel? Ninguém! Pois ele havia atendido as recomendações médicas e, finalmente, se curado ${ }^{137}$. Assim, a pedido do médico eugenista Renato Kehl ${ }^{138}$ em nome da Sociedade de Eugenia de S.

\footnotetext{
${ }^{130}$ Ibidem, 242.

${ }^{131}$ Ibidem, p. 259.

132 Ibidem, p. 243.

${ }^{133}$ Ibidem, p. 272.

${ }^{134}$ Ibidem, p. 270.

${ }^{135}$ HABIB, Paula A. B. B. op. cit.,p. 39.

${ }^{136}$ Ibidem, p. 40.

${ }^{137}$ MONTEIRO, L. Problema Vital... p. 340.

${ }^{138}$ Monteiro Lobato faz essa declaração no prefácio do livro Bio-perspectivas de Kehl, em 1938. (Cf. LOBATO, M. Prefácio. In. KEHL, Renato. Bio-Perspectivas... p. 17)
} 
Paulo e da Liga Pró-Saneamento do Brasil ${ }^{139}$, as 16 crônicas de Problema Vital foram enfeixadas em volume. O objetivo era demonstrar que o país era um vasto hospital repleto de doentes, e a única solução seria a implementação de uma política de saneamento em todas as cidades $^{140}$.

Desta maneira, fica evidente como Lobato se apropriou dos debates raciais de sua época e de como se utilizou da literatura como ferramenta em prol da ciência e da nação. $\mathrm{Na}$ medida em que mudava, suas personagens também se transformavam. Segundo Marisa Lajolo, "Monteiro Lobato parece ter percorrido quase todas as posições ideológicas disponíveis para um intelectual do seu tempo"141.

Se retornarmos alguns anos e questionarmos quais foram as leituras que influenciaram Lobato e contribuíram para a construção de uma imagem e de uma teoria do mundo e do homem, iremos diretamente para os primeiros anos de graduação do autor, e nos depararemos - em meio à Machado de Assis, Zola, Camilo Castelo Branco, Balzac, Tolstoi, Anatole France - com Spencer (evolucionismo), Darwin (evolucionismo), Voltaire (iluminismo), Comte (positivismo), Nietzsche (filosofia), Gustav Le Bon (psicologia coletiva), Stuart Mill (empirismo) e Taine (determinismo) ${ }^{142}$. Essa lista de autores que, de certa forma, inspiraram o pensamento de Lobato, constituem também um rol de escritores que influenciaram uma boa parte da geração intelectual do início do século $\mathrm{XX}^{143}$.

Monteiro Lobato cresceu em meio aos livros e enciclopédias da biblioteca de seu avô, o Visconde de Tremembé. Já na sua fase adulta, os seus principais meios de informação eram os jornais, e, principalmente os livros importados de outros países. Educado em um ambiente intelectual, foi influenciado diretamente pelos pensamentos de grandes nomes de sua época, principalmente, por Gustave Le Bon ${ }^{144}$. Esse psicólogo social teorizava sobre as diferenças entre as raças humanas. Acreditava que as diversidades culturais, os modos de pensar e agir, as crenças e a moral de uma população eram características transmitidas hereditariamente.

\footnotetext{
${ }^{139}$ LOBATO, Monteiro. Problema Vital... p. 22.

${ }^{140}$ HABIB, Paula A. B. B. op. cit., p. 33.

${ }^{141}$ LAJOLO, M. apud SANTOS, Ricardo Augustos dos. Lobato, os Jecas e a questão racial no pensamento social brasileiro. p. 4. Disponível em: <http://www.achegas.net/numero/sete/ricardo_santos.htm> Acesso em: julho de 2012.

${ }_{142}$ CASSAL, Sueli A. T. B. op. cit., p. 118.

${ }^{143}$ Idem.

${ }^{144}$ CAMPOS, André. Raça ou doença? O Problema Vital do Brasil. Ipotesi: Revista de Estudos Literários, Juiz de Fora, vol. 1, no 2 - p. 47.
} 
A energia, a perseverança, o gosto pelo trabalho, a iniciativa e o sentimento de família são qualidades que a hereditariedade pode dar mais que qualquer instituição pode criar. ${ }^{145}$

As características que faltavam ao Jeca Tatu (energia, trabalho e iniciativa) e eram reivindicadas por Lobato, eram as mesmas consideradas por Le Bon como essenciais para o aperfeiçoamento das populações. Esse filósofo acreditava que as características de uma sociedade poderiam ser transformadas por intermédio da hibridização racial ${ }^{146}$, pois as qualidades da raça superior se assimilariam as de outra raça e formariam um todo homogêneo. Logo, quando analisamos as características dos Jecas, encontramos consonâncias com essas teorias e com aquelas pregadas pelo movimento sanitarista e eugenista brasileiro. Isso demonstra o engajamento de Lobato e a maneira pela qual ele utilizava destas teorias científicas como embasamento para escrever suas obras literárias. Além disso, comprova que o escritor não estava dizendo coisa nova, apenas corroborando algumas teses e ideias que lhe pareciam pertinentes naquele dado momento.

Ao ser convertido pelas ideias da eugenia e do sanitarismo, Lobato renovou suas ideias e rendeu-se à teoria da perfectibilidade humana. O discurso determinista e evolucionista foi introduzido no Brasil no final do século XIX para explicar e justificar não mais somente o atraso econômico brasileiro, mas, principalmente, o atraso social, moral e cultural da nação. Os "tipos humanos" perigosos ${ }^{147}$ (negros, africanos, ex-escravos, trabalhadores rurais, deficientes físicos, mentais, alcoólatras, doentes venéreos, etc.) geravam certa preocupação para uma parte das elites intelectuais, pois os degenerados traziam incerteza ao futuro do Brasil como nação próspera e sã. Deste modo, recrudescia a ideia de que o negro e os tipos miscigenados eram signo de atraso, o que culminou no desenvolvimento de teorias que visavam refrear o seu avanço no seio da sociedade. O que estava em jogo era qual tipo de cidadão seria mais apropriado do ponto de vista hereditário e genético para formar e servir de exemplo para a nação.

A eugenia, também conhecida como a ciência dos "bem nascidos" e dos "puros", afirmava-se, então, como negócio de Estado, pois constituía peça fundamental na construção da nacionalidade e do aperfeiçoamento da população ${ }^{148}$. Segundo os "cientistas", a cura encontrava-se no processo de higienização e limpeza social, ou seja, aspirava-se por uma

\footnotetext{
${ }^{145}$ LE BON apud. CAMPOS, André. Raça ou doença?... p. 47.

${ }^{146}$ Idem.

147 SANTOS, Gislene Aparecida dos. A Invenção do Ser Negro: um percurso das idéias que naturalizam a inferioridade dos negros. São Paulo: Educ/Fapesp; Rio de Janeiro: Pallas, 2002. p. 120-121

${ }^{148}$ Idem.
} 
"reconstrução" social, uma vez que a miscigenação, cara à sociedade brasileira, era vista como o principal fator da estagnação do país. Eram necessárias novas medidas de contenção do avanço daqueles que impossibilitavam o progresso da nação.

Para estes intelectuais, uma das principais razões da crise atravessada pelo regime
republicano encontrava-se nas condições 'naturais' constitutivas do Estado
brasileiro. O Brasil estava sacudido por revoltas sociais e crises econômicas, não por
questões históricas ou políticas, mas - segundo eles - por causa do clima tropical e
da constituição étnica do povo. O brasileiro não tinha podido promover o
desenvolvimento harmônico do país porque o calor e a mistura com 'raças
inferiores' tinham-no tornado preguiçoso, ocioso, indisciplinado e pouco inteligente.
Infelizmente nada podia ser feito contra o clima. Em contrapartida, o problema
racial ainda podia ser resolvido. ${ }^{149}$

A natureza se apresentava como ordenadora das desigualdades para por fim estabelecer uma igualdade. Era o clima, o solo, o meio ambiente, e os genes que afetavam, tanto para o bem como para o mal, o aperfeiçoamento social. O homem, desta forma, deveria, racionalmente, como afirmava Galton, tomar as rédeas e controlar o desenfreado desenvolvimento humano, visto que a natureza agiria lenta e desordenadamente, caberia ao homem adiantar todo o processo que seria, um dia, natural e inevitável ${ }^{150}$. Essa premissa teórica eugênica serviu, mais tarde, como base para estruturar $O$ Choque das Raças, e explica a noção do inevitável conflito racial no futuro apregoado no romance.

Assim, a eugenia e o movimento científico eugênico, criado e difundido pelo cientista britânico Francis Galton, representam "as possíveis aplicações sociais do conhecimento da hereditariedade para obter-se uma desejada "melhor reprodução", 151 , bem como aprimorar a raça humana a partir da preservação daqueles indivíduos "puros”. Segundo Galton,

Eugenics is the science which deals with all influences that improve the inborn qualities of a race; also with those that develop them to the utmost advantage ${ }^{152}$.

Com a defesa de uma melhoria das qualidades inatas da raça, a eugenia ganhou espaço tanto na Europa como na América. Países como a Argentina, os Estados Unidos e o Brasil, foram grandes propulsores dessa ciência. No Brasil, fomentado por Renato Kehl ${ }^{153}$, essas ideias conquistaram muitos admiradores e adeptos. Monteiro Lobato, ao se deparar com a

\footnotetext{
${ }^{149}$ COSTA, Jurandir Freire. História da Psiquiatria no Brasil: um corte ideológico. $3^{\mathrm{a}}$ ed. revisada. Rio de Janeiro: Editora Campus, 1980. p. 31.

${ }^{150}$ GALTON apud SANTOS, Ricardo Augustos dos. Lobato, os Jecas e a questão racial no pensamento social brasileiro. Disponível em: < http://www.achegas.net/numero/sete/ricardo_santos.htm> Acesso em: julho de 2012.

${ }^{151}$ STEPAN, Nancy Leys. op. cit., p. 33.

${ }^{152}$ GALTON, F. op. cit.. p. 35.

${ }^{153}$ Médico, precursor da eugenia no Brasil e amigo de Lobato, defendia a esterilização dos ditos degenerados como prática eugênica e solução social.
} 
aplicação das ideias de Galton à realidade brasileira empregada por Kehl, enviou-lhe uma carta na qual diz se lamentar em conhecer um "espírito tão brilhante" como o dele somente naquele momento e o conclama "pai da eugenia" ${ }^{154}$ no Brasil.

Ao reafirmar a importância do saneamento dos campos e da Liga Pró-Saneamento em conjunto com a Sociedade Eugênica de S. Paulo, Renato Kehl como objetivo angariar mais aliados para, na sua opinião, nobre causa: sanear o Brasil ${ }^{155}$. Na ótica dos eugenistassanitaristas ${ }^{156}$, como na de Lobato, se fazia necessário, primeiramente, convencer o país de sua doença para depois saneá-lo ${ }^{157}$. Para eles, essas medidas eram mais do que profiláticas, eram medidas patrióticas em sua essência.

Trabalhar em defesa da nação e para a nação era um dever de cada um, afirmava Lobato no Problema Vital. Desta forma, o escritor e os demais eugenistas se viam como patriotas, pois trabalham a favor do Brasil e de suas gerações presentes e futuras. É interessante destacar que Lobato, ao escrever a saga do Jeca Tatu, não estava se dirigindo aos caipiras e aos caboclos. Ao se levar em consideração que grande parte da população naquele momento era analfabeta e que somente uma pequena parcela da sociedade paulista tinha contato diário com os periódicos nos quais o pai do Jeca escrevia, podemos afirmar, igualmente como o faz Habib ${ }^{158}$, que Lobato escreveu para os seus pares com a intenção de convocá-los a empreender o saneamento sanitário e social. Afinal, mesmo reconhecendo ser sanitário, não genético, o problema dos tantos Jecas espalhados pelo país, eles seguiam inferiores até serem curados e educados.

O clamor do escritor paulista era muito mais do que um protesto em nome do caboclo e a favor do sanitarismo rural. Sua intenção não era salvar o homem da terra porque ele era símbolo nacional, mas, sim, reabilitá-lo, porque somente assim ele poderia afinal colaborar

\footnotetext{
${ }^{154}$ SOUZA, Vanderlei Sebastião de. "A Eugenia no Brasil: ciência e pensamento social no movimento eugenista brasileiro do entre-guerras". In: Anais do XXIII Simpósio ANPUH, Londrina, 2005. Disponível em: $<$ http://www.bioeticaefecrista.med.br/textos/eugenia\%20no\%20brasil_ciencia\%20e\%20pensamento\%20social.p df $>$ Acesso em abril 2015.

${ }^{155}$ HABIB, Paula A. B. B. op. cit., p. 3.

${ }^{156}$ No Brasil, a eugenia confundia-se com a higiene sanitária, com o pensamento social e político local. Era, nas palavras de Vanderlei Sebastião de Souza, uma "ciência poliforma, uma forma de conhecimento cuja constituição se processou a partir da relação direta com outros ramos do pensamento científico e social" (SOUZA, Vanderlei Sebastião de. Em nome da raça: a propaganda eugênica e as idéias de Renato Kehl nos anos 1910 e 1920. Revista de História Regional, 11(2): 29-70, 2006a. Disponível em: <http://www.revistas2.uepg.br/index.php/rhr/article/view/2230>. Acesso em abril 2015.)

${ }^{157}$ LOBATO, M. O Problema Vital... p. 272.

${ }^{158}$ HABIB, Paula A. B. B. op. cit., p. 38.
} 
com o progresso de seu país. Recuperar o trabalhador brasileiro, para Lobato, era o mesmo que integrá-lo à nação por intermédio do trabalho produtivo e um ato patriótico.

Como pode-se ver, a adesão de Lobato aos conhecimentos científicos em prol da nação foi gradual. Observa-se, primeiramente, um contato com as ideias higienistas do movimento sanitarista e, mais tarde, de forma nítida, encontra-se o escritor entregue a vertente mais negativa da eugenia ${ }^{159}$, para a qual todos os seres considerados inferiores e degenerados deviam ser segregados ou, então, banidos.

Parafraseando aqueles que compreendiam a miscigenação como um mal desnecessário, Monteiro Lobato cristalizou essas ideias por intermédio de suas personagens. As transformações do Jeca evidenciam o processo de conhecimento e transformação do seu então criador. Contudo, é no romance $O$ Choque das Raças onde encontramos a face mais aguda do movimento eugênico de Lobato. Essa obra nos revela o lado eugenista, sanitarista e, consequentemente, nacionalista do autor. Admirado com a civilização norte-americana ${ }^{160}$, Lobato não mede palavras para glorificar essa nação. Utiliza-a como modelo ideal de Estado organizado e bem-sucedido. Entretanto, havia algo que atrapalhava o melhor desempenho desta nação, isto é, "o erro inicial”, "o caroço no sapato", o negro.

Concluindo, o Jeca Tatu não foi fruto do acaso, "criado de improviso" ${ }^{161}$. É o resultado da revolta de um fazendeiro lesado e entusiasmado com a ciência sanitarista. O Jeca, mais do que denunciar um país atrasado à beira do abismo, revela um literato sujeito de seu tempo, que, da mesma forma que suas personagens, se transformou ao longo da trajetória. Seu posicionamento frente ao caboclo doente e depois ressuscitado tinha como princípio o trabalho. Vieira de Campos demonstra que Lobato construiu um discurso progressista que "tinha como eixo central a noção de trabalho"162 e saúde.

Essa concepção de trabalho organizado e disciplinado, insistentemente defendida pelo escritor até o final de sua vida, denota a sua verdadeira preocupação nacional: o progresso econômico do Brasil. Ele acreditava que somente mediante a sistematização do trabalho e do controle dos trabalhadores o Brasil conseguiria chegar perto de países avançados como os

\footnotetext{
${ }^{159}$ Ibidem, p. 44. Mais adiante essa característica será melhor explorada.

${ }^{160}$ Uma das críticas feitas pelo crítico literário Faria Neves Sobrinho, logo após o término da publicação do romance, foi sobre algumas falhas que, na sua opinião, eram inadmissíveis, considerando o romance uma "obra ilógica e impatriótica”. (Ibidem, p. 86-87).

${ }^{161}$ CAMPOS, André L. V. A República do Pica Pau Amarelo..., p. 19.

162 Ibidem, p. 21.
} 
Estados Unidos, que já praticavam a segmentação da produção ${ }^{163}$. Assim, a noção de nacionalismo de Lobato nesse momento estava diretamente relacionada à noção de trabalho e economia. O programa patriótico do saneamento sugerido por ele visava atender a melhora dos homens e mulheres que sofriam os percalços de um Estado negligente com o seu povo. $\mathrm{O}$ Jeca, símbolo da miséria e do atraso, podia agora, através do saneamento e da eugenia, tornarse forte, um excelente trabalhador e rico.

\section{O editor e proprietário da Revista do Brasil}

É inegável afirmar que uma parte da intelectualidade do início do século XX refletia sobre a constituição racial do Brasil. A visão de mundo elaborado por ela era resultado de um esforço que visava desvendar os problemas nacionais e encontrar as soluções em prol de uma sociedade mais homogênea. Sevcenko aponta que as principais exigências feitas pelos intelectuais daquele momento eram: a modernização das estruturas da nação tendo em vista o modo de vida europeu, com a integração do país em uma unidade internacional, e a elevação do nível cultural e material da nação ${ }^{164}$. Para se chegar a esse fim, inúmeras eram as alternativas e propostas, pois a corrida em prol das características genuinamente nacionais revelava algumas formas de apropriação e tentativa de "explicar a realidade nacional e de propor projetos que (re)colocariam o Brasil nos trilhos"165.

Assim, ao delegar para si essa tarefa, alguns intelectuais outorgavam-lhes o direito à verdade, pois, acreditavam que podiam, a partir daquele momento, estabelecer parâmetros que melhor lhes conviessem e representar o país da maneira que mais os interessassem. A busca pelos elementos estruturais da nação e o esforço para compreender as particularidades brasileiras eram reflexos de um contexto marcado por crises, desordens e transformações. Pensar sobre o país tornava-se "quase que uma compulsão"166, afirma Tânia R. de Luca.

\footnotetext{
163 Lobato nutria grande admiração não somente pelo Fordismo, modelo de produção e de vida, mas, especialmente, à própria pessoa do Henry Ford. Seu entusiasmo para com ele se demonstra pelas traduções e publicações, pela Companhia Editora Nacional, da autobigrafia de Ford, Minha Vida e Minha Obra, em 1926, e de Hoje e Amanhã, em 1927. Além da publicação de um opúsculo de sua autoria, em inglês, How Henry Ford is Regarted in Brazil, em 1926. (QUELUZ. op. cit., p.)

164 SEVCENKO, Nicolau. Literatura como missão: tensões sociais e criação cultural na Primeira República. $2^{\mathrm{a}}$ ed. São Paulo: Companhia das Letras, 2003. p. 97.

${ }^{165}$ Ibidem, p. 19.

${ }^{166}$ DE LUCA, Tânia R. op. cit., p. 18.
} 
A imagem de um país jovem, "em infância"167, em fase de amadurecimento, justificava o seu atraso e a sua falta de identidade. Éramos um edifício em construção, um gigante de mãos atadas, um laboratório social. Se, em termos industriais, econômicos e sociais, éramos deficitários, por outro lado, tínhamos um patrimônio geográfico belíssimo, o qual muitos tentaram enfatizar. No entanto,

a visão grandiosa fornecida pela geografia contrapunha-se uma história sem cor ou brilho, circunstância que causava uma sensação de profundo desconforto, tornada ainda mais incômoda na medida em que a essas disciplinas atribuía-se a nobre função de ensinar aos cidadãos a cartilha do patriotismo. ${ }^{168}$

Do que adiantava sermos bonito por natureza e feios como o Jeca? Nosso passado era sombrio e suas marcas estavam impregnadas em nosso sangue e imagem. Clamava-se por uma nova história com novos representantes, urgia-se por uma construção de identidade nacional. Rubens do Amaral ${ }^{169}$, por exemplo, dizia acreditar que o Brasil seria somente uma nação quando todos os indivíduos tivessem os mesmos ideais. Contudo, os ideais ainda não eram os mesmo porque não havia princípios unívocos que representassem a todos da sociedade $^{170}$. Por isso, dizia que existiam "diversos nacionalismos" ${ }^{\text {"171 }}$, onde cada um pensava a nação de uma forma diferente.

Neste gosto dos brasileiros pelas coisas brasileiras, percebe-se a reação do nacionalismo incipiente, que não é xenofobia porque não odeia o estrangeiro: é o mimetismo com que os povos defendem o seu caráter próprio. Devemos incentivar essa reação, procurando generalizá-la principalmente porque ainda tem feição muito reacionária. Se somos um País e um Estado, não somos ainda uma Nação. Nação é um conjunto de homens da mesma raça ligados pela mesma língua, pelas mesmas tradições, pelos mesmos interesses e pelos mesmos ideais. ${ }^{172}$

O mimetismo não era de todo recriminado por Amaral. No entanto, acreditava que somente importar ideias não transformaria o país numa nação. Para ele, nação era um conjunto de homens interlocutores de uma mesma língua, de costumes e interesses semelhantes. A realidade do Brasil era bem heterogênea, pois de norte a sul falava-se uma língua diferente e cultuavam-se interesses distintos.

\footnotetext{
${ }^{167}$ Ibidem, p. 40.

${ }^{168}$ Ibidem, p. 86.

169 Rubens do Amaral foi um importante jornalista e escritor brasileiro que também fez parte da Academia Paulista de Letras

${ }^{170}$ AMARAL, Rubens do. Manifestações do nacionalismo. Revista do Brasil. São Paulo, Volume XII. Setembro - Dezembro, 1919. Ano IV ( $\left.{ }^{\circ} 45-48\right)$, p. 220.

${ }^{171}$ Idem.

172 Idem.
} 
Por outro lado, Antônio Sampaio Dória, um jurista e educador alagoano, julgava ser a pátria "uma realidade universal e perene" ${ }^{173}$, porém, difícil de ser definida com precisão. Admitia que pátria era um conjunto harmônico entre povo, território, unidade de governo soberano, tradições culturais, língua e aspirações nacionais. O Brasil, segundo ele, não era "a mais brilhante de todas as pátrias" 174 , mas era "a melhor de todas"175, bastava comparar todos os seus elementos constitutivos com os das pátrias estrangeiras. No entanto, faltava apenas "a intensa e extensa educação popular" ${ }^{, 176}$ para evidenciar a potencialidade da raça em produzir bons e grandes homens.

Desta forma, vários "nacionalismos" surgiam, alguns mais pessimistas, outros mais positivos e confiantes, como aquele pregado por Dória. Parte dos intelectuais que levou à frente essa missão de cunho nacionalista aproveitou-se da imprensa como meio de divulgação para disseminar os ideais nacionais por eles estabelecidos. Jornalistas, literatos, médicos, educadores, cientistas e políticos encheram as páginas dos jornais e revistas da época com manifestos, propagandas e textos que visavam à propagação de ideias salvadoras da pátria. Ora, a imprensa era o único veículo de informação de ampla divulgação ${ }^{177}$, no início do século. O jornalismo, portanto, absorvia quase toda a atividade intelectual e dava abrigo a grande parte do grupo de literatos brasileiros. ${ }^{178}$

Foi dessa forma que surgiu, em 1916, a Revista do Brasil. Periódico preocupado com os rumos do país e, especialmente, com os rumos da literatura nacional, a Revista tinha um objetivo claro: o "redespertar da consciência nacional"179. No número inaugural, os editores começavam explicando os objetivos do veículo e conclamavam a elite burguesa brasileira:

O que há por trás do título desta Revista e dos nomes que a patrocinam é uma coisa
simples e imensa: o desejo, a deliberação, a vontade firme de constituir um núcleo
de propaganda nacionalista. Ainda não somos uma nação que se conheça, que se
estime, que se baste, ou, com mais acerto, somos uma nação que ainda não teve o
ânimo de romper sozinha para a frente numa projeção vigorosa e fulgurante da sua
personalidade. Vivemos desde que existimos como nação, quer no Império quer na
República, sob a tutela direta ou indireta, senão política ao menos moral do
estrangeiro. Pensamos pela cabeça do estrangeiro, vestimos pelo alfaiate
estrangeiro, comemos pela cozinha estrangeira e, para coroar essa obra de servilismo

${ }^{173}$ DORIA, A. de Sampaio. Pátria. Revista do Brasil. São Paulo, Volume VII. Janeiro - Março, 1918. Ano III. $\left(n^{\circ} 26-28\right)$, p. 230.

${ }^{174}$ Idem.

175 Idem.

176 Idem.

177 SEVCENKO, Nicolau. op. cit. p. 274.

${ }^{178}$ Ibidem, p. 125.

${ }^{179}$ Ibidem, p. 35. 
coletivo, calamos, em nossa pátria, muitas vezes, dentro dos nossos lares, a língua materna para falar a língua do estrangeiro. [...]

Desapego á vida, lume no espírito e generosidade no coração tudo isto nos sobra. Tudo isto, porém, de nada, ou de muito pouco nos vale porque, até hoje, ora mais, ora menos, nos tem faltado uma coisa que é a mola real de todos os triunfos, assim dos indivíduos como das nações: a consciência do nosso valor. [...]

O nosso povo precisa aprender, ou recordar, que há, no seu sangue e na sua tradição, essa força imponderável que nos leva naturalmente, insensivelmente para os cimos, que nos reserva ao pé dos nossos semelhantes, sem violências, como um direito indisputado, um lugar especial e honroso, e que tem sido em todos os tempos e em todos os pontos do mundo, a marca inconfundível das raças adultas, emancipadas e sadias. [...]

A 'Revista do Brasil', desejando contribuir para que Ela se acenda de novo, com uma luz mais viva e duradoura, na alma abatida do país, entendeu que podia realizar essa obra de patriotismo, provocando estudos do passado, que nos desvendarão, nas coisas e nos homens, uma larga fonte de inspiração, de amor e de orgulho, e estimulando todas as energias atuais para um trabalho de observação e criação científica e literária, que nos patenteie a todos a profundez e a riqueza dos nossos tesouros intelectuais. [...]

O nacionalismo desta revista visa até, pelas suas tendências e pelas raias do horizonte que se traçou, um fim mais humano que regional. [... $]^{180}$

Peço, primeiramente, desculpas pela extensa citação, mas acreditamos que ela resume muito bem a intenção da Revista e a maneira pela qual ela entendia o nacionalismo. Ao propor um veículo de comunicação que promovia a identidade nacional e o seu despertar, os diretores do periódico estavam por definir seus conceitos de nação, de nacionalidade e de Brasil. Contra os estrangeirismos exacerbados e a favor da cultura brasileira, a Revista e seus colaboradores pretendiam trazer à tona um sentimento de pertencimento e conhecimento das raízes do povo brasileiro, pois, acreditavam que o desconhecimento de si mesmo acarretava na aceitação e na "imitação subserviente de tudo o que vinha de fora"181. A intenção não era negar a importância do elemento estrangeiro, mas "estimular estudos sobre o país e formas a se revitalizar seu imenso potencial artístico e intelectual" ${ }^{182}$.

Nascia, assim, a Revista do Brasil, proveniente de uma sociedade anônima paulista composta por sessenta acionistas, em sua maioria políticos, intelectuais e jornalistas ligados ao grupo do Estado de S. Paulo. Era então dirigida por Júlio Mesquita, Alfredo Pujol e Luiz Pereira Barreto. Seu redator-chefe era o Plínio Barreto e o secretário-gerente o J. M. Pinheiro Júnior. Pela proposta ousada e destoante das demais revistas, a Revista do Brasil usufruiu de grande prestígio na sociedade desde suas primeiras edições.

\footnotetext{
${ }^{180}$ Grifos nossos. Nota de abertura da Revista: "Revista do Brasil". In: Revista do Brasil. Vol. I. Janeiro - abril, 1916. Ano I. (n 1 ao 4). p. 1-5.

${ }^{181}$ DE LUCA, Tânia R. op. cit., p. 47.

182 AZEVEDO, Carmen L., et al. op. cit., p. 110.
} 
Diferentemente das outras revistas em circulação, nas quais o entretenimento era carro chefe, a Revista do Brasil tinha um caráter mais teórico e seus textos eram mais analíticos e eruditos $^{183}$. Fotografias ou ilustrações não eram recorrentes. Com exceção das caricaturas (sempre na seção "As Caricaturas do Mês"), pouco ou nenhum desenho aparecia, pois o objetivo não era entreter, mas, sim, instruir e instigar a consciência política e nacional. Outra característica que a diferenciava das demais revistas era a sua estrutura física muito semelhante ao livro. Com brochura para suportar a numerosa quantidade de páginas ${ }^{184}$ dos volumes, sua capa (em tom verde escuro) era formal, sem nenhuma imagem, contendo apenas o seu nome, bem ao estilo dos livros daquele período.

As semelhanças com os livros extrapolavam as questões físicas:

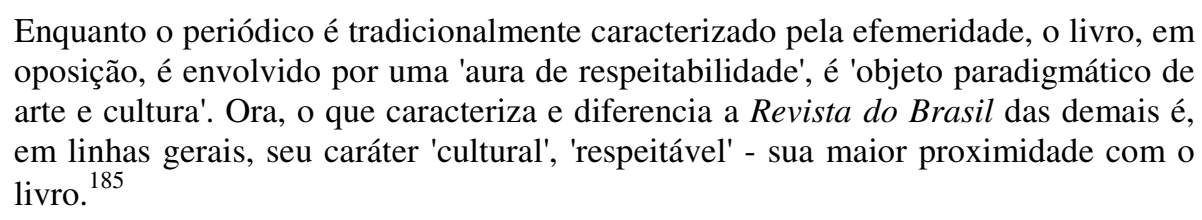

Em atividade de 1916 até meados de 1925, a Revista do Brasil apresentava solidez em suas publicações, seus artigos tinham teor teórico profundo e repleto de fortes opiniões. A interdisciplinaridade era marca do periódico, pois apresentava textos de diferentes áreas, indo da literatura à medicina, das artes plásticas à economia. Apesar de apresentar temáticas de diferentes áreas do saber, seu conteúdo central era sempre o mesmo: a nação e sua identidade.

Compartilhando do mesmo projeto social nacional, Monteiro Lobato participou ativamente da Revista desde o seu início com contos, resenhas e textos de crítica literária e de artes. Acreditava que o elemento estrangeiro, especialmente o francês, apresentava-se como obstáculo à visão da população brasileira, fazendo-a ter olhos e admiração somente para o que vinha do outro lado do Atlântico. Poder escrever em uma revista em que compartilhava a mesma visão de mundo e que se propunha a apresentar um país até então desconhecido e/ou esquecido era, para Lobato, "caso de tomares assinatura"186.

Antes de se tornar diretor e dono da Revista, o escritor chegou a publicar nove contos da coletânea Urupês nas páginas desse periódico ${ }^{187}$. Sua admiração por essa revista e pelo seu

\footnotetext{
${ }^{183}$ MARTINS, Milena R. op. cit., p. 19.

${ }^{184}$ Cada volume tinha em média cerca de 400 páginas.

${ }^{185}$ Ibidem, p. 22.

${ }^{186}$ LOBATO, M. Barca de Gleyre... (t. 2), p. 64.

${ }^{187}$ Em todos eles teorizava sobre a indolência e inadaptabilidade à civilização do caboclo.
} 
manifesto era grande antes mesmo de sua aquisição, e Lobato não media esforços em divulgála para os amigos.

Já viste a Revista do Brasil? É caso de tomares uma assinatura. Nasceu de boa estirpe, está bem aleitada pelo Estado, é a única nesse gênero em todo o país - e é nossa. Já no segundo número devo ocupar-lhe dez páginas com um conto de monjolos e monjoleiros, coisa muito buquirana, daqui - Chóó-pan. ${ }^{188}$

O conto inaugural do autor, sobre monjolos e monjoleiros, foi A vingança do Peroba, inspirado na sua vivência como fazendeiro. Depois dele, Lobato chegou a publicar 29 contos na revista entre 1916 e 1923, todos eles posteriormente publicados nos livros Urupês, Cidades Mortas, Negrinha, O Macaco que se fez homem, e Na Antevéspera. Assim, de colaborador assíduo, Monteiro Lobato passou a ser o proprietário da Revista em $1918^{189}$.

Cansado da vida no campo e consciente do seu sucesso como escritor, Lobato resolve vender a fazenda do Buquira (que estava em decadência) por cerca de 40 mil dólares ${ }^{190}$ e mudar-se para São Paulo. A proposta inicial, conta Lobato, era substituir o então diretor Plínio Barreto, mas revela a Rangel uma mudança de curso: "minha ideia é substituir-me à

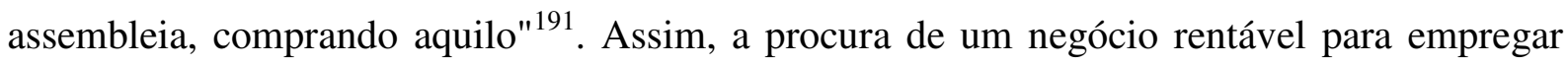
seu dinheiro ${ }^{192}$, Lobato decide comprar o periódico.

Mais do que algo lucrativo, investir na Revista lhe garantia "o estabelecimento de outras relações econômicas e sociais por outros mecanismos"193 que não fossem somente colaborar em diferentes periódicos ou comprar outra fazenda (e ter que lidar com a "pior peste do mundo"). Dessa maneira, o escritor, além de se tornar proprietário da Revista do Brasil em 1918, se tornava também editor e diretor ${ }^{194}$. Mais tarde, empreenderia novamente abrindo a sua primeira editora. Lobato iniciava assim não só mais um negócio, mas uma revolução editorial.

\footnotetext{
${ }^{188}$ Idem.

${ }^{189}$ HABIB, Paula A. B. B. op. cit., p.31.

${ }^{190}$ CASSAL, Sueli A. T. B. op. cit., p. 71.

${ }^{191}$ LOBATO, M. Barca de Gleyre... (t. 2), p. 159-160.

${ }^{192}$ LOBATO, M. Prefácios e Entrevistas... p. 253.

193 VALENTE. Thiago A. Monteiro Lobato nas páginas do jornal: um estudo dos artigos publicados em $\mathrm{O}$ Estado de S. Paulo (1913-1923). São Paulo: Cultura Acadêmica, 2010. p. 51-52,

194 "A direção da Revista muda em 1918, ano em que ela é comprada por Monteiro Lobato, que assume a direção. De junho a dezembro de 1919, a Revista é dirigida por Lobato e Lourenço Filho. A partir de janeiro de 1921, n 61, os diretores são Afrânio Peixoto e Amadeu Amaral. Em julho do mesmo ano, n 67, Afrânio Peixoto e Monteiro Lobato. Em janeiro de 1922, Monteiro Lobato e Brenno Ferraz. Em abril de 1922, $\mathrm{n}^{\circ} 76$, Ronald de Carvalho também ingressa na direção. Em janeiro de 1923, n 85, Monteiro Lobato e Paulo Prado são os diretores. E, a partir de fevereiro de 1924, Sérgio Milliet é Secretário." (MARTINS, Milena. op. cit., p. 25)
} 
Agora, sob nova direção, a Revista dobrava o número de assinantes. Em setembro do mesmo ano, Lobato anuncia que o periódico ia bem:

Quando me fiquei com ela, entravam em media 12 assinaturas por mês. Hoje entra isso por dia. Nesta primeira quinzena de agosto registrei 150 assinantes novos. Meu processo é obter em cada cidade o endereço das pessoas que lêem e enviar a cada uma o prospecto da revista, com uma carta direta e mais coisas - iscas. E atiço em cima o agente local. Estou a operar sistematicamente pelo país inteiro. ${ }^{195}$

O aumento repentino do número de assinantes não deve ser visto apenas como resultado da mudança da direção da revista. Durante a década de 1910 e 1920, o nome de Lobato estava estampado em diversos jornais e revistas, mas foi, sobretudo, com a publicação dos artigos Uma Velha Praga e Urupês que o escritor conquistou a imprensa e um número considerável de leitores. Assim, a sua popularidade foi apenas um dos condicionantes que levou ao aumento do número de assinantes da Revista. Outro fato de suma importância foi a campanha publicitária ${ }^{196}$ empreendida por Lobato. A partir desse momento, Lobato levará mais a sério o seu ofício de escritor e passará a ter um olhar para literatura mais de empreendedor. Agora o escritor via na literatura também uma forma de ganhar dinheiro e de fazer "psicologia comercial"197.

Ao se dar conta que o mercado literário brasileiro era diminuto e que grande parte do que se produzia circulava apenas no eixo Rio-São Paulo, o literato, e agora também diretor e editor, encontrara novas formas de impulsionar o mercado livreiro. Por meio da elaboração de uma pequena pesquisa, Lobato descobriu que havia apenas 40 livrarias por todo o país e teve a seguinte ideia:

- 'Isso está errado'[...]. 'Impossível um negócio desse jeito - assim privado de varejo.
Mercadoria que só dispõe de quarentas pontos de vendas está condenada a nunca ter
peso no comércio de uma nação. Temos de mudar, fazendo uma experiência em
grande escala, tentando a venda do livro no país inteiro, em qualquer balcão que
exista e não somente em livraria'. Mandamos uma circular a todos os agentes do
correio pedindo a indicação de uma casa, de uma papelaria, de um jornalzinho, de
uma farmácia, de um bazar, de uma venda, de um açougue, de qualquer banca, em
suma, em que também pudesse ser vendida uma mercadoria denominada 'livro'. [...]
Conseguimos mil e duzentos nomes de casas comerciais recomendadas como
relativamente sérias. ${ }^{198}$

Monteiro Lobato iniciava uma revolução no mercado brasileiro de livros. Até aquele momento ninguém havia empreendido uma campanha de tamanho vulto. Os resultados foram

\footnotetext{
${ }^{195}$ LOBATO, M. Barca de Gleyre... (t. 2), p. 179-180.

196 "Editar é fazer psicologia comercial" (Ibidem, p. 298). Thiago Valente explora bem a personalidade publicitária de Monteiro Lobato Cf.: VALENTE. Thiago A. op. cit.

${ }^{197}$ LOBATO, M. Barca de Gleyre... (t. 2), p.

${ }^{198}$ LOBATO, M. Prefácios e Entrevistas... p. 190.
} 
impressionantes, "um abalo no país inteiro"199. A procura de livros aumentara consideravelmente. As edições passaram de 400 exemplares para uma média de três mil exemplares $^{200}$. Lobato encarava o livro e a literatura como mercadoria. Assim sendo,

O novo proprietário imprimiu reformulações nos critérios de seleção do corpo de artigos, como indica o fato de haver desaparecido da contracapa, a partir do número 34, a informação de que a revista só publicava trabalhos inéditos. Também é notória a preocupação em se tornar o mensário mais leve e atraente, aumentando o espaço dedicado à criação literária. ${ }^{201}$

Acreditamos que essa nova postura foi fruto da experiência que o literato obtivera ainda como estudante. Ao colaborar quase que integralmente para o jornaleco Minarete como escritor, jornalista e publicista, Lobato criara uma mentalidade voltada para o público leitor. Uma simples análise do público era reveladora de suas intenções e desejos. A elite erudita brasileira era quem mais assinava a Revista e desejava ler os artigos sobre a "verdadeira" cara da nação disseminada por outros intelectuais. Era um círculo restrito, ainda mais se pensarmos que a população alfabetizada brasileira que tinha acesso ao periódico era diminuta. Lobato, integrante dessa elite, fez pequenas e importantes reformulações na Revista. Mas, não se engane, tudo foi em prol de lucros, e não só de um projeto nacionalista.

O ano de 1918 foi bastante produtivo para o pai do Jeca, como podemos ver. Além de todos os empreendimentos e publicações já ditos, ele desenvolveu, numa pequena sala da Revista do Brasil, o "embrião de uma seção editora" ${ }^{202}$. Com a experiência bem-sucedida das publicações autofinanciadas de Saci-Pererê: resultado de um inquérito e de Urupês ${ }^{203}$, no ano seguinte, juntamente com Olegário Ribeiro, formou a sociedade mercantil de responsabilidade limitada Olegário Ribeiro, Lobato e Cia, dissolvida no mesmo ano. Em 1920, com Octalles Marcondes, montou a Monteiro Lobato \& Cia. Com a grande demanda e crescimento dos negócios, surgia em 1924 a Cia Gráfico Editora Monteiro Lobato ${ }^{204}$. Com as crises de energia, alta dos preços do papel importado e o movimento-político tenentista em São Paulo, falia a empresa em 1925. Contudo, Lobato não desistiu do sonho editorial e abriu a Companhia Editora Nacional que teve vida mais estável a partir de 1926.

\footnotetext{
${ }^{199}$ Ibidem, p. 191.

${ }^{200}$ Idem.

${ }^{201}$ DE LUCA, T. op. cit., p. 66.

${ }^{202}$ DE LUCA, T. op. cit., p. 122.

${ }^{203}$ A primeira edição desse livro, com mil exemplares, saiu em pouco menos de um mês.

204 BIGNOTTO, Cilza. Monteiro Lobato em construção. p. 8. Disponível em: <http://www.unicamp.br/iel/monteirolobato/outros/cilza01Lobato.pdf $>$. Acesso em jan. 2014.
} 
Agora Lobato pensava e agia como homem de negócio e não mais apenas como escritor. Além de aplicar uma nova dinâmica no sistema de compra e venda de livro no Brasil, ele promoveu uma melhoria no padrão gráfico dos livros por intermédio de uma programação visual mais sofisticada e tipografia mais elegante ${ }^{205}$. A apresentação física importava tanto quanto o seu conteúdo. O trabalho de editor ia além da reprodução de livros, era, para Lobato, um trabalho cheio de artimanhas que requeria psicologia comercial e "iscas", isto é, publicidade.

Livro é sobremesa: tem que ser posto debaixo do nariz do freguês, para provocar-lhe a gulodice. [...] Deve-se enfiar o livro nas mãos do possível comprador, meio à força, como fazem os cambistas sabidos com os bilhetes de loteria. ${ }^{206}$

Essa visão de negócio fez com que Lobato se tornasse um dos precursores em sua área e conquistasse sucesso. Vale ressaltar que no Brasil, até o lançamento dos primeiros livros editados pelo escritor, havia poucos editores profissionais e um mercado editorial ainda incipiente. Lobato trouxe uma visão diferenciada para esse negócio, inovou porque lançava escritores novos e pagava direitos autorais compensadores ${ }^{207}$. Buscou novas formas de divulgação e de vendas dos livros. Ocupou o primeiro lugar entre as empresas brasileiras dedicadas exclusivamente à edição de livro com a Companhia Editora Nacional ${ }^{208}$. O Lobato Editor não inventou um mercado editorial, todavia, contribuiu para que o já existente se ampliasse e incorporasse novas formas de funcionamento. Proporcionou aos escritores publicados maiores margens de lucros e aos leitores, caras e nomes diferentes do circuito habitual.

Com o então crescente triunfo, Lobato planejava ser daquele momento em diante, apenas "negociante"209, pois dispunha do "mais moderno parque gráfico da época", transformando-se na "maior e mais importante empresa do ramo no país" ${ }^{210}$. Em entrevista, Oswald de Andrade pergunta a Lobato sobre o seu próximo livro, e ele responde: "Qual livro!

\footnotetext{
${ }^{205}$ AZEVEDO, Carmen L., et al. op. cit., p. 131.

${ }^{206}$ MONTEIRO, L. apud AZEVEDO, Carmen L., et al., idem.

${ }^{207}$ HALLEWELL, Laurence. O livro no Brasil: sua história. São Paulo: Editora da Universidade de São Paulo, 1985. p. 250. Hallewell conta que embora muitos livros viessem estampados com nomes de editora, na maioria das vezes, era o próprio autor que arcava com os custos da impressão do livro.

${ }^{208}$ Ibidem, p. 254

209 "A minha obra literária, Rangel, está cada vez mais prejudicada pelo comercio. Acho que o melhor é encostar a literatura e enriquecer; depois de rico e, portanto, desinteressado do dinheiro, então desencosto a coitadinha e continuo. E não será longo o encostamento - um três anos, a avaliar pela violência com que este negócio cresce." (MONTEIRO, L. A Barca de Gleyre...(t. 2), p. 231)

${ }^{210}$ AZEVEDO, Carmen L., et al. op. cit., p. 137
} 
Pretendo ser apenas negociante" ${ }^{211}$. De fato, podemos observar que houve uma diminuição nas produções literárias e a ausência temporária de Lobato na direção da Revista do Brasil, no entanto, não houve um total abandono para uma exclusiva dedicação à editora. Ele continuava a colaborar com textos curtos para periódicos paulistas e cariocas.

O crescimento e prosperidade da marca Monteiro Lobato era grande, mas "não se assentavam em bases sólidas" 212 . Apesar dos lucros, muitas dívidas foram contraídas para a instalação da moderna oficina gráfica. Ademais, a conjuntura histórica não o favoreceu em nada. Revolução de 1924; política deflacionária do governo Bernandes; seca; crise no sistema de abastecimento de energia elétrica; foram só alguns dos problemas que surgiram no meio do caminho e que levaram Lobato à falência. Em 1925, chegava ao fim a Companhia GráficoEditora Monteiro Lobato e, consequentemente, a Revista do Brasil ${ }^{213}$.

Apesar dos lucros obtidos com a Revista e com a editora, Lobato não conseguira quitar seus empréstimos com o banco e foi à bancarrota ${ }^{214}$. Alguns dos seus colegas creditavam o ocorrido ao fato do escritor/editor ser um sonhador ${ }^{215}$ e não ter dado a devida importância ao contexto histórico crítico daquele momento. Embora soubesse que o cenário econômico e político era desfavorável, o Lobato empresário não se esmoreceu e não deixou de investir em novas máquinas e tecnologias. Acreditava que a maré baixa seria passageira, e confiava em suas negociações editoriais complementadas com as suas colaborações em jornais e revistas.

Embora falido, o Lobato sonhador continuava sua trajetória sem desanimar. Associouse novamente a Octalles Marcondes e reabriu a Companhia Editora Nacional. Declarava a Rangel que, "Decididamente temos estrela, porque é difícil conseguir, a quem sai duma

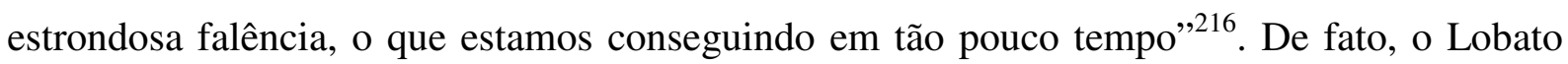
não parava de idealizar. Já imaginava para a editora recém-inaugurada até cinco filiais, e "uma livraria em casa capital do Brasil" $" 217$. Entretanto, o que vimos foi outro quadro. Embora a empresa seguisse firme, ele possuía menos ações e rendimentos que anteriormente, e sabia

\footnotetext{
${ }^{211}$ Ibidem, p. 129.

${ }^{212}$ DE LUCA, Tânia R. op. cit., p. 76

${ }^{213}$ Seu último número saiu em maio de 1925. Ao total, foram 113 edições mensais ininterruptas.

${ }^{214}$ Vale ressaltar que o banco no qual Lobato fez os empréstimos para comprar os novos maquinários da editora foi o London Bank. Por coincidência ou não, o romance $O$ Choque das Raças se inicia com um diálogo entre colegas na fila do mesmo banco.

${ }^{215}$ CASSAL, Sueli A. T. B. op. cit., p. 69.

${ }^{216}$ LOBATO, M. Barca de Gleyre... (t. 2), p. Carta de 1925

${ }^{217}$ Idem.
} 
que somente com isso não conseguiria se manter. Precisava se enveredar novamente pelo caminho da literatura e fazer sucesso como outrora.

Escrever poderia ser uma saída para pagar as dívidas até então contraídas. Já com ideias a muito sendo "gestadas", eis que Monteiro Lobato tem a ideia de colocar no papel um romance futurista a la Wells, com pitadas de realidade que seriam travestidas de invenção e criatividade. O escritor, como visto, acreditava que arte era sinônimo de vida, uma “objetivação do sujeito"218. Ferramenta de trabalho, a realidade (observada por ele) era reproduzida com intensidade e ardor com propósitos patrióticos. Dessa forma, além de buscar uma saída para os infortúnios econômicos, $O$ Choque das Raças também tinha uma intenção social e pedagógica: ensinar e convencer os seus leitores de um tipo específico de eugenia.

Lobato se fez literato por força de uma denúncia injusta e superficial, na qual apresentava apenas suas versões, sem nunca ouvir o seu Jeca. Apenas os homens da ciência conseguiram se fazer ouvir por ele. A partir deste momento, testemunhamos um Lobato simpatizante da ciência e que quer se redimir com sua criação. Essas transformações, como visto, demonstram mais do que uma nova visão para com o Jeca, demonstram as mudanças intelectuais vivenciadas pelo autor. Apresentam como ele se apropriou da ciência para fazer literatura. Revelam o caráter nacionalista do Lobato que vislumbrava nas letras um eficaz instrumento de transformação social.

Com as suas futuras obras não será diferente. O caráter nacionalista permanecerá, a única coisa que irá mudar são as formas de se conseguir sucesso financeiro e prestígio social. Analisaremos, a seguir, como o romance $O$ Choque das Raças expõe um debate nacionalista e como Monteiro Lobato se apoderou dos discursos raciais e eugênicos em defesa de uma nação perfeita e, especialmente, branca. Será evidenciada a experiência e a formação de Lobato a fim de entender a proposta por ele apresentada. O nacionalismo pregado por Lobato nessa primeira fase de sua vida esteve pautado no trabalho e no saneamento estrutural. Agora, em $O$ Choque, veremos que ele vestira uma nova roupagem, ainda mais ousada.

\footnotetext{
${ }^{218}$ CAVALHEIRO, E. Monteiro Lobato: vida e obra... p. 72.
} 


\section{Capítulo 2: O Choque das Raças: "A imaginação a serviço da lógica"219}

Certa vez, Monteiro Lobato comparou sua produção literária a uma gestação, na qual gestava ideias até ficaram maduras e prontas para serem colhidas. Esse processo não tinha tempo certo, nem características próprias, precisava apenas ficar alojado em seu íntimo, numa espécie de tumor ${ }^{220}$. Por isso reclamava com o seu confidente e amigo Godofredo Rangel dos inúmeros pedidos de textos dos periódicos para os quais colaborava ${ }^{221}$. Dizia ser impossível "parir",222 quando não estava "grávido",223, e, por isso, mais abortava do que procriava.

Essa metáfora nos remete a mais uma faceta do Lobato literato e nos ajuda a encaixar algumas peças soltas do imenso quebra-cabeça lobatiano. Mais do que uma sátira de si próprio, Lobato acreditava que o ofício de escritor requeria uma certa obsessão pelos temas. O Jeca Tatu é um excelente exemplo disso, pois, para a concepção de sua personalidade, foi necessária uma gestação de anos, e, mesmo depois de moldado, foi modificado. Grande parte dos contos e crônicas escritos entre 1914 e 1918 tinha uma relação direta ou indireta com a imagem do caboclo, que somente ganhou contornos definidos em Urupês.

Com $O$ Choque das Raças não foi diferente. Esse romance, único de sua carreira, expressa outro período de gestação. Nele enxergamos um aprimoramento das ideias já então gestadas anteriormente e seladas na figura do Jeca. Inegavelmente de caráter eugenista, essa obra demonstra o posicionamento científico e político do Lobato nacionalista. Traz à tona o que um dos seus lados mais pessimistas. O Lobato editor dava espaço agora ao Lobato racista e romancista.

Nesta obra, o escritor empenha-se em lidar com conceitos e teorias eugênicas. Para isso, cria uma máquina do tempo cujo objetivo é enxergar o futuro, definido por ele como já pré-determinado. A partir dessa "engenhoca" denominada Porviroscópio, traz conceitos, teorias, e explicações que, segundo os partidários da eugenia, poderiam levar a sociedade à evolução plena. A obra de Lobato explora bem os debates a respeito das teorias racialistas

\footnotetext{
${ }^{219}$ O Choque das Raças ou o Presidente Negro. O Jornal. Rio de Janeiro, 5 de janeiro 1927, Ano IX, n. 2.477, p. 3. Disponível em <http://memoria.bn.br/DocReader/DocReader.aspx?bib=110523_02\&PagFis=29994>. Acesso em julho de 2015.

${ }^{220}$ LOBATO, M. A Barca de Gleyre... (t. 1), p. 56. Carta de 23.10.1915.

221 "Aquilo [Revista do Brasil] está se tornando um Moloch insaciável. Querem dar um conto meu em cada número, como se eu fosse uma máquina.” Cf.: Ibidem, p. 136. Carta de 22.4.1917.

222 Idem.

${ }^{223}$ Idem.
} 
daquele momento e as questões que alimentavam os debates acadêmicos. Reproduz a premissas de Galton, o criador da eugenia, de que a natureza se encarregaria de ordenar as desigualdades raciais, uma vez que previa a luta pela sobrevivência dos mais aptos. Essa premissa teórica serviu de base para estruturar O Choque das Raças, e explica, de modo preciso, a sua opção de um romance futurista. Se o conflito racial era inevitável no futuro, fazia-se necessário adiantar o processo que, no Brasil, seria mais complexo do que nos Estados Unidos, tendo em vista a mistura racial.

O autor estrutura seu romance num caráter reflexivo, e nos apresenta algumas possibilidades de sentido para a miscigenação e para os problemas sociais do país. $O$ Choque das Raças - que mais tarde virá a ser chamado de O Presidente Negro - trabalha com uma narrativa inserida em duas temporalidades e em dois lugares bem marcados e distintos. $\mathrm{O}$ Brasil do presente, espécie de incerteza e questionamento; e o futuro dos EUA, lugar de afirmação e de certeza. Suas personagens Ayrton Lobo, Professor Benson (inventor da máquina do tempo) e sua filha Miss Jane, se deslocam no espaço-tempo a fim de persuadir o leitor aos conhecimentos ali apresentados. Esse jogo temporal é um artifício do qual o autor se utiliza para sugerir um certo tipo de ação eugênica e induzir o leitor a tirar conclusões próprias, fundadas nas teorias raciais que defende ${ }^{224}$.

Categoricamente intrigante, $O$ Choque foi publicado diariamente ${ }^{225}$ ao longo de vinte e uma edições seguidas nas páginas do jornal carioca $A$ Manhã. Numa espécie de folhetim, definindo uma leitura a conta gotas, estimulando a curiosidade e a reflexão dos leitores, Lobato procura educar os leitores conforme os princípios eugênicos. Constrói uma ficção que se passa nos Estados Unidos para apresenta determinadas soluções para o embate racial, que culmina no extermínio da raça negra. Nesse ínterim, as personagens dialogam entre si expondo os debates científicos da época, e exprimem o discurso das mulheres e negros do futuro, para então conduzir os leitores a refletirem sobre o Brasil do presente, ou seja, daquele ano de 1926.

Apesar de uma parte dos pesquisadores da atualidade alegar que esse romance foi escrito para dialogar com a realidade dos Estados Unidos, sabemos e temos evidencias suficientes para dizer o contrário. O Choque das Raças foi, sim, escrito sobre o Brasil e para o

\footnotetext{
${ }^{224}$ Ao longo do capítulo exploraremos melhor essa questão de espaço e tempo apresentada no romance.

${ }^{225} \mathrm{O}$ romance foi publicado diariamente no mês de setembro, iniciando-se no dia cinco. Contudo, nos dias 18/09, 28/09 e 30/09 não houve edição dos capítulos. Não sabemos os porquês, mas presumimos que nos dias finais da obra, Lobato e/ou diretores d'A Manhã decidiram causar mais suspense, pois os desfechos são instigantes e impulsionam a continuar a leitura.
} 
Brasil. Nosso objetivo aqui, mais do que relacionar as interlocuções do romance aos acontecimentos históricos, é compreendê-lo e analisa-lo a partir de seu primeiro meio de publicação. Quais as peculiaridades de se publicar um romance em um periódico? Uma vez que Lobato ainda estava gerindo a Companhia Editora Nacional, por que escolheu publicar a obra primeiramente em um jornal? Ler o romance n'A Manhã nos possibilita encontrar novos sentidos e novas interpretações sobre o romance. A partir dessa experiência conseguimos entender uma certa organização e lógica estrutural que só existe no jornal e que tem um sentido de ser: convencer os leitores à proposta final. As pausas diárias, por exemplo, demonstram como e onde Lobato escolheu parar a narrativa para deixar um gostinho de quero mais, estimulando a curiosidade e a reflexão, pois o leitor somente poderia dar continuidade a leitura no dia posterior.

O Choque das Raças reflete muitas das questões e debates políticos, científicos e literários de uma sociedade recém-egressa da escravidão que se via às voltas com um conjunto renovado de dilemas sócio-raciais. É também resultado de uma jornada pessoal nacionalista de Lobato orientada por padrões ideológicos vigentes a sua época ${ }^{226}$. Nessa perspectiva, inserimos o romance num contexto social e político mais amplo para entender a lógica interna da obra, suas personagens e enredo, ou seja, toda a estrutura literária que faz com que $O$ Choque seja uma obra tão inquietante.

Em toda a trajetória literária de Lobato conseguimos visualizar planos e modelos de uma sociedade ideal. Segundo Paula Habib, podemos vislumbrar dois paradigmas, o "que encontramos em $O$ Choque das Raças e na saga do Sítio do Pica-Pau Amarelo" ${ }^{\text {227. No }}$ entanto, como não nos cabe aqui analisar esses dois modelos, esboçaremos algumas possibilidades de sociedade aspirada por Lobato, tendo em vista os diálogos empregados pelo autor em $O$ Choque.

Homem de negócios, com visão de publicitário, Lobato não se preocupava apenas com a aparência e estrutura física de seus produtos literários. Preocupava-se, também, com a compreensão e receptividade de seus leitores. Percebemos que essa obra apresenta uma linguagem mais coloquial, diferentemente das anteriores, recheadas de neologismos e linguagem culta. Acreditamos, portanto, que a publicação num jornal com uma linguagem mais simples e um enredo de cunho social e político tinha como pretensão atrair e convencer

${ }^{226}$ Segundo Antônio Cândido toda obra literária sofre influência dos fatores socioculturais. Cf.: CÂNDIDO, Antônio. Literatura e sociedade. $9^{\circ}$ ed. Rio de Janeiro: Ouro sobre azul, 2006, p. 30.

${ }^{227}$ HABIB, Paula A. B. B. op. cit., p. 16. 
mais do que cientistas, literatos, jornalistas e intelectuais de uma forma em geral. A intenção, nos parece, era alcançar a todos, e, sobretudo, homens e mulheres das camadas mais baixas.

A forma como foi construída a trama do romance demonstra seu caráter didático e seu intuito em explicar e convencer que a eugenia fora a melhor solução para os Estados Unidos e, por conseguinte, seria da mesma forma o melhor caminho para o Brasil. Essas teorias ecoaram fortemente entre as camadas mais intelectualizadas e não tiveram grande repercussão entre as camadas mais modestas da sociedade. A eugenia, a grande protagonista dessa narrativa, se apresenta como símbolo de respeito e amor pela pátria, de grande importância social, sendo de responsabilidade de $\operatorname{todos}^{228}$, e por essa razão deveria ser amplamente difundida.

Assim, do mesmo modo que a personagem Miss Jane analisa os diferentes períodos históricos da humanidade na engenhoca inventada por seu pai, o Porviroscópio, denominando cada época de "cortes anatômicos",229 , utilizaremos essa mesma terminologia para comentar as diferentes passagens e temáticas do livro. Utilizaremos recortes específicos, que serão analisados em conjunto com a obra e com outras referências que foram necessárias e pertinentes. Desta forma, desvelamos uma estrutura na qual é possível entender a lógica comparativa entre presente e futuro do romance. Do mesmo modo, tentamos evidenciar as diferenças e implicações presentes no conteúdo apresentado tanto no livro como no jornal. Mas, tomemos fôlego, partiremos agora rumo ao caminho de $O$ Choque das Raças a fim de destrinchar sua história passo a passo. Não queremos quebrar o encanto da narrativa sem antes descrevê-la.

\section{O Choque das Raças na A Manhã}

O 'romance americano' de que A MANHÃ adquiriu os direitos de publicação não
lembra nenhum outro. O professor Benson, velho sábio residente num misterioso
'castelo' na serra de Friburgo, descobre o meio de captar a onda que resume a vida
universal do momento. Envelhece no cronizador essa onda, produzindo assim o
tempo artificial. Por este meio consegue descerrar as cortinas do futuro e ver o que
vae dar-se no porvir com precisão absoluta. Do muito que viu no futuro da
humanidade coisa nenhuma o impressionou tanto como o choque das raças na
América, drama ocorrido, ou que ocorrerá no ano 2228 . Os negros são cem milhões
e os brancos duzentos. Sobrevém o inevitável conflito e a raça branca resolve o

${ }^{228}$ Lobato, provavelmente, não alcançou as camadas mais pobres da sociedade. Ele e todos os demais intelectuais empreendidos na campanha pró-saneamento e eugenista embora escrevessem para periódico de grande vulto na época, acabaram falando mais para os seus pares, tendo poucos ecos nos meios mais humildes.

${ }^{229}$ LOBATO, M. O choque das raças. Jornal A Manhã: Rio de Janeiro, 5 de setembro 1926, ano II, n. 215 , p. 5. 
binômio racial por uma forma inteiramente imprevista. O romance de Monteiro Lobato [...] vem agitar os mais sérios problemas da espécie humana. É um hino á Eugenia, às leis espartanas revividas na América e é um brado d'armas em prol do princípio mágico que está fazendo da América do Norte um mundo dentro do mundo - a Eficiência. ${ }^{230}$

O Choque das Raças começou a ser publicado no periódico A Manha $\tilde{a}^{231}$ no dia cinco de setembro de 1926. Ao longo de vinte e um dias, as palavras de Monteiro Lobato tomaram conta das páginas desse diário. A exclusividade da publicação fez com que A Manhãa, nos dias que precederam o início da publicação do romance, anunciasse diariamente o inédito romance lobatiano, além de lhe conceder espaço privilegiado em suas páginas ${ }^{232}$. Tanto que no primeiro dia de publicação, o romance apareceu estampado e centralizado na primeira página do jornal e ainda ganhou lugar de destaque na página cinco, inteiramente dedicada a ele.

Muito esperado pela direção do jornal, cinco foram as chamadas (propagandas) sobre o romance, todas estrategicamente bem localizadas. No primeiro dia do mês de setembro a primeira chamada aparecia na segunda página, no canto superior esquerdo da folha. No dia seguinte, surge centralizada na parte superior da página. Na sexta-feira, terceiro dia consecutivo, a chamada aparece novamente na primeira página, porém centralizada na parte inferior $^{233}$. No sábado, o texto é curto e encontra-se no canto inferior esquerdo da página dois. No quinto e último dia, também dia da publicação do romance, o redator lança outra chamada/resumo desta obra. Essas propagandas contêm indícios do que estava por vir, buscavam instigar a curiosidade e despertar o interesse pela obra, artifício para divulgar e promover a mais nova empreitada de Lobato.

Ao celebrar a personalidade de Monteiro Lobato e trazer breves resumos de sua nova obra, A Manhã jogou com a curiosidade e com as expectativas do leitor. Não bastavam as propagandas do romance, nem mesmo a obra em si. Era preciso também informar aos

\footnotetext{
${ }^{230}$ LOBATO, M. O choque das raças. A Manhã: Rio de Janeiro, 3 de setembro 1926, ano II, n. 213, p. 1.

231 Matutino versátil, com uma média de doze páginas em tamanho standart, A Manhã foi lançado no Rio de Janeiro em 29 de dezembro de 1925 por Mário Rodrigues. O tom virulento e agressivo do periódico se contrastava com a linguagem bem-humorada e descomplicada. Seu programa de atuação era claro: confrontar e denunciar as irregularidades das oligarquias da República Velha, bem como apoiar as causas populares. Foi uma "típica folha oposicionista", contrária ao governo de Washington Luís e ao prefeito do Rio, Antônio Prado Jr. (cf.: HABIB, Paula A. B. B. op. cit., p. 60; e A Manhã (Rio de Janeiro, 1925), s/a. Disponível em: $<$ https://bndigital.bn.br/artigos/a-manha/>. Acesso em janeiro de 2015).

${ }^{232}$ No primeiro dia de publicação, o romance aparece centralizado na parte superior da primeira página do jornal e na página 5, dedicada exclusivamente para ele. Durante os demais dias, o romance apareceu na página 5, com exceção para dois dias nos quais o romance foi lançado na página 4. Em todos os dias o espaço dedicado à obra de Lobato era um pouco menos da metade da página, sempre na parte inferior. O Choque das Raças dividia espaço com a seção artística e com textos de assunto corriqueiros e levianos do jornal, como, por exemplo, com a seção Nos Teatros, Na Feira das Vaidades e Cinematográficas.

${ }^{233}$ Esta é a chamada citada no corpo do texto.
} 
desavisados e relembrar aos atentos quem era Monteiro Lobato e quais eram seus trabalhos mais celebrados. Assim, cinco dias após a publicação do romance, o jornal passou a divulgar textos do famoso crítico literário Agrippino Grieco sobre o escritor ${ }^{234}$. No total foram cinco artigos sobre Urupês, Jeca Tatu, Cidades Mortas, Bocatorta e Negrinha. A intenção, ao que parece, era reafirmar a importância da façanha literária lobatiana, pois ele havia desaparecido do cenário em razão, segundo Grieco, da sua aventura pelo mundo dos negócios. Para ele, a paixão pela editora e a ganância pelos $\operatorname{lucros}^{235}$ foram os principais motivos que levaram o literato à bancarrota. No entanto, Lobato regressava com um "grande livro moderno"236 para todos os gostos, "para intelectuais e também para homens do povo"237, anunciava o crítico.

$\mathrm{O}$ romance, a princípio, surgia como uma tentativa de triunfo às adversidades econômicas e representava, em última instância, a aspiração do autor em permanecer no topo do mercado literário e nas mentes dos brasileiros. Em correspondência ao cunhado Heitor, Lobato revela que contraíra tantas dívidas com a editora e que precisava pagá-las escrevendo e trabalhando ${ }^{238}$. Desejava que $O$ Choque pudesse ser sua salvação, pois acreditava fielmente em seu estrondoso sucesso. Desta forma, A Manhã teve papel fundamental na reconstrução da figura de Lobato que, desde o dia $01.01 .1926^{239}$, passou a integrar o corpo de literatos e jornalistas do matutino.

Não sabemos ao certo como Lobato conheceu o então diretor d’A Manhã, Mário Rodrigues, ou como era relação dos dois. No entanto, as laudatórias e enaltecedoras propagandas deixam evidente que a redação do jornal carioca tinha, no mínimo, uma admiração e grande interesse financeiro por Lobato, caso contrário, não investiria tanto na divulgação de sua obra. Por outro lado, Lobato alegava que havia abandonado $O$ Estado de $S$. Paulo e optado pel'A Manhã porque este último tinha maior tiragem: "Passei-me para A

${ }^{234}$ Cf.: HABIB, Paula A. B. B. op. cit., p. 82; e GRIECO, Agripino. Monteiro Lobato: "Urupês". Jornal A Manhã: Rio de Janeiro, 10 de setembro 1926, ano II, n. 219, p. 2.

${ }^{235} \mathrm{Em}$ carta endereçada a Godofredo Rangel, Lobato reconhece como a editora estava atrapalhando sua produção literária: "A minha obra literária, Rangel, está cada vez mais prejudicada pelo comércio. Acho que o melhor é encostar a literatura e enriquecer; depois de rico e, portanto, desinteressada do dinheiro, então desencosto a coitadinha e continuo. E não será longo o encostamento - uns três anos, a avaliar pela violência com que este negócio cresce." (Carta de 30.5.1921 - LOBATO, M. A Barca de Gleyre... (t. 2), p. 231)

236 Idem.

237 Idem.

238 "Os tempos estão maus para todos, digo, para os que perderam tudo quanto tinham e têm de recomeçar a vida como eu. [...] Eu estou recém-saído de uma falência e ainda além de perder tudo o que possuía, caí na asneira de constituir dívidas. Saí devendo o que não recebi. É o cúmulo do sentimentalismo, digo, burrice. E tenho de trabalhar para pagar juros de uma dívida assim - de dinheiro que não tomei para mim e foi aplicado em ações de nossa companhia, de que eu era apenas um diretor! Mas quem burro nasce, burro morre. Vou pagando pela vida afora o imposto de minha burrice." (Cf.: LOBATO, M. Cartas escolhidas..., p. 189)

${ }^{239}$ Com seus artigos, sempre na página 3. 
Manhã do Mario Rodrigues, que está com a maior tiragem do Brasil. Cada número é um estouro de bomba., 240 .

Questionamos se essa união estabeleceu-se apenas por interesses individuais e comerciais. Ora, tanto o diretor como o literato pensavam no lucro, especialmente, Lobato, recém-saído de um cataclisma financeiro. Essa relação, a princípio, parecia benéfica para ambos os $\operatorname{lados}^{241}$. Lobato publicaria seus textos e seria pago por seu trabalho ${ }^{242}$, enquanto Mário Rodrigues, estamparia em seu periódico o nome de uma das figuras mais emblemáticas do início do século XX. Também não descartamos a ideia do escritor paulista ter financiado a publicação do romance e, principalmente, as suas propagandas. Paula Habib questiona se o sucesso d'A Manhã poderia ter incentivado Lobato a querer publicar seu romance nesse periódico, ou "será que Mário Rodrigues ofereceu mais dinheiro pelos direitos de publicação? Ou, talvez, a hipótese mais provável, todas essas suposições juntas ajudaram na decisão?"243

O fato é que, infelizmente, temos poucas fontes para responder esses questionamentos. Sabemos, por exemplo, que A Manhã, embora recente na praça, era um dos periódicos de maior tiragem do Rio de Janeiro, e, o mais importante, que Lobato era um homem articulador, com visão de negócios. O que nos leva a acreditar que ele, provavelmente, não estava jogando com a sorte, mas, também, empreendendo. Por mais que tivesse inúmeras dívidas, é provável que ele possa ter financiado as propagandas de $O$ Choque com o objetivo de colher os frutos como outrora o fizera em Urupês e O Inquérito do Saci. Assim, da mesma forma que Lobato escolheu A Manhã por interesse, é possível que este periódico também o tenha acolhido por interesse próprio.

Lobato, a essa altura, já possuía uma reputação consolidada no mundo das letras, como podemos observar nas inúmeras referências produzidas nos jornais da época. A Gazeta de Notícias, por exemplo, periódico carioca de grande vulto na sociedade brasileira de 1920,

\footnotetext{
${ }^{240}$ LOBATO, M. A Barca de Gleyre... (t. 2), p. 283.

${ }^{241}$ Paula Habib observa que o nome de Monteiro Lobato não aparece na lista da edição comemorativa de um ano do jornal, na qual aparecem os nomes e caricaturas dos colaboradores. O que pode demonstrar um certo distanciamento do escritor com a redação do jornal. (Cf.: HABIB, Paula A. B. B. op. cit., p. 77)

${ }^{242}$ Não sabemos o valor real que Lobato recebia por cada texto n'A Manhã. Contudo, com base em suas remunerações anteriores, podemos estimar que era um valor considerável. Vejamos: em 1909, Lobato diz que $O$ Estado de S. Paulo lhe pagava $10 \$ 000$ por cada artigo. Ainda no mesmo ano, revela que numa série de artigo para a Tribuna consegui 40\$000, o necessário para pagar "dois meses do aluguel da casa”. Já, em 1915, famoso pelo conto Urupês, diz que o Estado de S. Paulo iria pagar-lhe $25 \$ 000$ por cada artigo que escrevesse. Esses valores são relativos ao período em que o autor começava a ganhar fama, o que nos leva a pensar que em 1926 seu ordenado era consideravelmente maior. Cf.: LOBATO, M. A Barca de Gleyre... (t. 1), p. 273; e LOBATO, M. A Barca de Gleyre... (t. 2), p. 19.

${ }^{243}$ HABIB, Paula A. B. B. op. cit., p. 81-82.
} 
exalta Lobato em toda e qualquer oportunidade. Seus livros, crônicas e contos são sempre comentados e reverenciados. Em 1921, Lobato foi homenageado com um banquete por um grupo de intelectuais paulistas e o jornal não deixou de tomar nota ${ }^{244}$.

A Manhã parecia, então, confiar na importância e notoriedade do escritor, caso contrário não faria tanto alarde em torno de $O$ Choque das Raças. Além de prestigiar Lobato, as propagandas sobre seu novo romance, que logo ocuparia as bombásticas páginas do diário de Mário Rodrigues, trazem em seu texto o perfil de cada personagem e explica o sentido da obra anunciando o seu tema: o choque entre as raças branca e negra. O propósito era contextualizar o enredo do romance com os problemas sociais e políticos vigentes não só nos Estados Unidos, mas, especialmente, no Brasil.

O objetivo de Lobato era "descerrar as cortinas do futuro"245. Ao narrar o inevitável choque das raças ocorrido nos Estados Unidos de 2228, apresenta aos seus leitores os "mais sérios problemas da espécie humana"246, e traz à tona, indiretamente, o embate racial vivenciado pela sociedade brasileira do momento. Assim, o autor recorria à "Imaginação, sempre firme na Lógica" 247 com o intuito de criar uma "visão de futuro onde grande número dos sonhos" daquela época apareciam "plenamente realizados". O romance coloca em voga as práticas e incertezas das teorias eugênicas sobre as misturas raciais, sobretudo, alerta quanto os problemas trazidos pelo elemento negro.

Consciente desse delicado tema para uma sociedade miscigenada, A Manhã lança, em sua última chamada, uma nota justificando o enredo de $O$ Choque. Diz que esse romance foi escrito para o público norte-americano e que cabia ao leitor não julgar a obra sob o ponto de vista brasileiro, mas, sim, sob o olhar de lá2 ${ }^{248}$. Embora Lobato estivesse falando da sociedade brasileira e propondo algumas soluções para os problemas nacionais, podemos enxergar como

\footnotetext{
244 "Homenagem ao escritor Monteiro Lobato - banquete oferecido pelos intelectuais paulistas: Realizou-se hoje, no Palace Hotel o grande banquete oferecido pelos intelectuais de S. Paulo ao escritor Sr. Dr. Monteiro Lobato. Durante o banquete foram trocados vários brindes." Cf.: Homenagem ao escritor Monteiro Lobato: banquete oferecido pelos intelectuais paulistas. Gazeta de Notícias: Rio de Janeiro, 07 de agosto de 1921, ano XLVI, n. 216, p. 5.

${ }^{245}$ O Choque das Raças: romance americano de Monteiro Lobato. A Manhã: Rio de Janeiro, 03 de setembro de 1926, ano II, n. 213, p. 1.

${ }^{246}$ Idem.

${ }^{247}$ O Choque das Raças: romance americano de Monteiro Lobato. A Manhã: Rio de Janeiro, 02 de setembro de 1926, ano II, n. 212, p. 1.

248 "Cumpre, todavia, não perder-se de vista que 'O Choque' foi escrito especialmente para o público americano, e pois havemos de julgá-lo não do nosso ponto de vista, mas do ponto de vista do grande povo da Norte América. Isso aliás não exige grande esforço do leitor inteligente." (Cf.: O Choque das Raças: romance americano de Monteiro Lobato, adquirido pela "A Manhã". A Manhã: Rio de Janeiro, 05 de setembro de 1926, ano II, n. 215, p. 2.
} 
estratégica essa nota. Ela lança luz sobre o caso norte-americano e dissimula sobre o brasileiro, da mesma forma que o romance faz, o que nos leva a questionar se o autor dessas chamada não teria sido o próprio Lobato. Sua trajetória como literato evidencia seu posicionamento frente ao debate racial da época, que já havia denunciado as mazelas da sociedade brasileira e condenado abertamente os problemas inerentes ao cruzamento entre raças. Agora, mais maduro e convicto de suas ideias, vinha dar o golpe final.

Defendemos a hipótese que $O$ Choque é um romance de tese, ou seja, que tem uma essência um princípio norteador, um propósito de ser. Sua intenção primeira é educar seus leitores da mesma forma com que Miss Jane faz com o personagem principal e narrador, Ayrton Lobo. Concordamos, igualmente com Habib, Thiago Valente e Emerson Tim ${ }^{249}$, que essa obra, como todas as demais de Lobato, possui um caráter didático. O Choque, embora aparentemente seja direto e explícito em suas propostas e ensinamentos, é dissimulado e perspicaz - um artifício narrativo bastante significativo, que será comentado mais adiante. $\mathrm{O}$ autor não usa meias-palavras para dizer o que quer, mas se utiliza de metáforas sutis para expor suas teorias. De forma simples, porém enigmática, Lobato propõe uma saída para o binômio racial de sua época e dialoga com os leitores por intermédio de suas personagens.

Provavelmente, o fácil acesso e constituição simples do jornal foram também essenciais na escolha do autor em publicar $O$ Choque n'A Manhã. Utilizando-se deste meio, Lobato seria capaz de abranger um maior número de leitores não-intelectuais ${ }^{250}$ e divulgar os seus ideais eugênicos. Os limites da publicação do periódico obrigavam os leitores a fazerem pausas diárias, trazendo momentos de reflexão e gerando uma situação propícia para “ensinar" e convencer o público das ideias propostas. Além disso, as crônicas de Agripino Grieco e as chamadas anteriores do romance contribuíram muito para a divulgação da imagem de Lobato, principalmente, porque introduziram as demais obras do autor para o seu público.

No entanto, como já sabemos, a obra não teve o sucesso esperado e não tirou o nosso literato do sufoco financeiro. Lobato hoje é reconhecido por inúmeras obras, menos pelo $O$ Choque. O que aconteceu? Por que há um silêncio em torno dessa obra ao longo de décadas?

\footnotetext{
${ }^{249}$ HABIB, Paula A. B. B. op. cit., p. 15; VALENTE. Thiago A. op. cit., p. 85; TIN, Emerson. Anedota ou doutrinação? A interpretação equivocada em três contos de Monteiro Lobato. Intersecções: revista de estudos sobre práticas discursivas e textuais. Ano 3, n. 1, abril, 2010.

${ }^{250}$ De acordo com Maria Alice R. de Carvalho, o início do século XX é caracterizado pela urbanização acelerada, crescimento da população e concentração de homens pobres e pouco escolarizados nas cidades. Esses fatos justificam a emergência de uma nova imprensa, e um novo tipo de jornal: "mais barato, redigido de forma simples e recheado de informações sobre crimes e esportes". Conferir: CARVALHO, Maria Alice R. de. Irineu Marinho: imprensa e cidade. São Paulo: Globo Livros, 2012, p. 39.
} 
Talvez a conjuntura social da época, o conteúdo do romance, bem como as propagandas que antecederam e sucederam a publicação do romance consigam explicar uma parte desse questionamento, mas acreditamos que não sejam suficientes. Além disso, o tema extrapola as intenções da presente pesquisa. Nosso objetivo é, antes de tudo, entender a lógica narrativa do romance e ressaltar as características exclusivas de sua publicação em periódico. Acreditamos que assim é possível compreender os sentidos internos da obra e dialogar com algumas fontes de sua época.

\title{
Um romance em prol de uma "sábia ciência"
}

\begin{abstract}
Ponho-me às vezes a imaginar como seriam as coisas cá na terra se um sábio eugenismo desse combate à desonestidade por meio da completa eliminação dos desonestos. Que paraíso! ${ }^{251}$
\end{abstract}

À espera de sua vez, no "London Bank",252, Ayrton Lobo se encontra e conversa com um corretor de negócios conhecido seu o qual lhe faz ponderar, "com os olhos parados de quem pela primeira vez reflete numa ideia" ${ }^{, 53}$, sobre as práticas e efeitos de uma "sábia ciência”: a eugenia. Personagem principal e narrador, Ayrton Lobo é uma espécie de espelho de homens brasileiros. Ele personifica uma camada da população que não tinha acesso aos ensinamentos eugênicos, mas que era passível de doutrinação. Sabiamente, Lobato usa Ayrton Lobo para acolher os desinformados do debate racial, coloca em suas falas questionamentos que poderiam surgir de qualquer leitor leigo no assunto. Submete-o a um processo de iniciação aos saberes eugênicos e, logo, descreve um processo de educação. Quase adepto aos conhecimentos ali pregados, a personagem questiona e duvida inicialmente de algumas informações. Desta forma, Ayrton Lobo representa ser mais um representante da camada média pouco educada.

O autor dá o tom da história e fisga seus leitores logo no início quando diz que um "sábio eugenismo" seria uma solução capaz de acabar com a desonestidade do país e, consequentemente, com as diversas burocracias então existentes. O tema, aliás, já fora

\footnotetext{
${ }^{251}$ Grifos nossos. LOBATO, M. O Choque das Raças. A Manhã: Rio de Janeiro, 05 de setembro de 1926, ano II, n. 215 , p. 1.

${ }^{252}$ Banco no qual Lobato contraiu empréstimos para tentar se salvar da falência. Mais uma evidência de que Lobato se utilizou de muitos elementos de sua realidade para escrever esse romance. Cf.: AZEVEDO, Carmen L., et al. op. cit., p. 149.

${ }^{253}$ Grifos nossos. LOBATO, M. O Choque das Raças. A Manhã: Rio de Janeiro, 05 de setembro de 1926, ano II, n. 215 , p. 1.
} 
apresentado pelo jornal nos anúncios ao romance. Quando Ayrton reflete pela primeira vez sobre o assunto, podemos questionar se muitos dos leitores também não fizeram o mesmo lendo o romance, e se de fato a intenção do autor era construir uma espécie de simbiose entre o público e o personagem principal.

Desta forma, nosso primeiro "corte anatômico" neste capítulo é sobre o processo de modernização cultural, social e moral empreendido pelos adeptos da eugenia. Monteiro Lobato foi adepto, partidário e interlocutor destes ideais, ora como escritor, jornalista, empreendedor, adido financeiro ou como cidadão. O Choque das Raças surge num ato nacionalista, no qual Lobato almeja moldar a sociedade brasileira de acordo com os padrões estabelecidos pela ciência.

Escrito em vinte dias ${ }^{254}$, "ao correr da pena", o romance futurista é, se assim podemos dizer, o palco no qual Monteiro Lobato expõe, de forma simples e pragmática, suas ideias sobre miscigenação, feminismo, ciência, política e eugenia. $\mathrm{O}$ autor, acreditando nas teorias científicas de Galton, "resolveu traduzi-las e popularizá-las em um romance",255. Aproveitando o ensejo, lançou mão das ideias futuristas do escritor britânico Herbert George Wells (1866-1946), considerado o pai da ficção moderna, por quem nutria grande admiração. Seu fascínio para com este escritor era antigo, assim como a vontade de escrever algo que o intitulasse o "Wells de Taubaté". Por isso, confessando-se a Godofredo Rangel, seu fiel amigo de longas datas e inúmeras missivas, disse, em 1905, que estava se preparando para uma produção futurista. No entanto, não tinha pressa, pois tempo era o que menos lhe importava naquele momento.

Ando com ideias dumas coisas à Wells, em que entrem imaginação, a fantasia possível e vislumbres do futuro - não o futuro próximo de Júlio Verne, futurinho de 50 anos, mas um futuro de mil anos. Vou semear essas ideias e deixá-las se desenvolverem livremente por dez ou vinte anos - e então limito-me a fazer a colheita, caso a plantação subsista até lá. Se a terra dos meus canteiros mentais não

\footnotetext{
${ }^{254}$ Lobato conta a seu amigo Godofredo Rangel da facilidade em se escrever esse romance: "Nunca me julguei capaz de conduzir um romance até o fim, e no entanto lá o pari em 20 dias. Como é 'canja' escrever um romance! Disse-o ontem ao Coelho Neto e ele amoitou. Saiu um romance inteiramente desligado da minha velha literatura regional. Veio coisa do futuro - lá do ano 2228." (carta de 07.02.1927; LOBATO, M. A Barca de Gleyre... (t. 2), p. 287). Em outra correspondência endereçada ao médico-sanitarista Arthur Neiva, Lobato comenta sobre seu feito, e pede sua opinião: "Fi-lo em 20 dias, ao correr da pena, e aproveitando muitas ideias que um dia lhe comuniquei. Quero dedicar esse livro ao Dr. mas antes desejo sua opinião. Vou mandar-lhe uma cópia logo que a copista me entregar o que lhe pedi. Peço-lhe que leia e sugira-me mais alguma coisa aproveitável." (Carta s/d. LOBATO apud HABIB, Paula A. B. B. op. cit., p. 91).

${ }^{255}$ HABIB, Paula A. B. B. op. cit., p. 89.
} 
for propícia a essas sementinhas, então é que não estou destinado a ser o H. G. Wells de Taubaté, e paciência. ${ }^{256}$

Vinte e um anos depois, Lobato vem colher os frutos da semente de outrora. Somando Galton a Wells ${ }^{257}$, Monteiro Lobato escreveu um romance futurista-eugenista. Construiu uma narrativa que dialoga com o presente e o futuro, na qual os EUA estão trezentos e dois anos à frente do Brasil de 1926. Desta forma, propôs-se a traduzir e popularizar essas ideias e teorias acreditando ser esta ciência a única opção inteligente para a cura da doença do país, isto é, a miscigenação e sua consequente inferioridade racial, moral, social e econômica. De quebra, não perdeu a oportunidade de combater o feminismo em voga no Brasil e alhures.

Assim sendo, a narrativa começa com Ayrton Lobo descrevendo seu primeiro contato com a "sábia ciência", apresentada rapidamente por um colega corretor no "London Bank", e longamente esmiuçada por seus futuros amigos. A partir desse momento, os cinco primeiros $\operatorname{capítulos}^{258}$ (todos lançados no primeiro dia de publicação) irão se ocupar em descrever as personagens Ayrton, Professor Benson e Miss Jane. A breve descrição de cada uma delas nos oferece um panorama geral da história e alguns subsídios para dialogar personagem e criador $^{259}$.

O Professor Benson é apresentado, inicialmente, como "positivamente misterioso"260, "um magico que vê através do futuro" 261 , que joga na Bolsa de Valores e nunca perde. O segredo em torno de sua figura começa a ser desvelado já no final do primeiro capítulo, quando, numa obra do acaso, encontra-se com Ayrton, que acabara de sofrer um acidente de carro, e o hospeda em sua casa. A partir desse encontro, Professor Benson irá revelar seu grande mistério, mas não antes de fazer mais suspense e colocar uma pulga atrás da orelha do leitor. Ao longo dos cinco capítulos do primeiro dia de publicação, somente os leitores mais atentos e que acompanharam as chamadas do jornal, sabem sobre a existência de uma máquina do tempo.

\footnotetext{
${ }^{256}$ LOBATO, M. A Barca de Gleyre... (t. 1), p. 113. Carta de 17.12.1905.

${ }^{257}$ Monteiro Lobato traduziu e publicou pela Companhia Editora Nacional algumas obras desse escritor britânico na década de 30: O Homem Invisível, A Ilha das Almas Selvagens, História do Futuro, O Destino da Espécie Humana, A Construção do Mundo.

${ }^{258}$ O desastre; A minha aurora; O capitão Nemo; Miss Jane e Tudo éter que vibra são, respectivamente, os capítulos 1, 2, 3, 4 e 5 .

${ }^{259}$ Segundo Forster, as personagens de um romance são, grosso modo, "porção de massas verbais" que o escritor se utiliza para se descrever: "Elas não chegam frias à sua mente, podendo ser criadas em delirantes excitações. Sua natureza, no entanto, está condicionada pelo o que o romancista imagina sobre outras pessoas e sobre si mesmo, e, além disso, é modificada por outros aspectos de seu trabalho." (Cf.: FORSTER, E. M. Aspectos do romance. Trad. Maria Helena Martins. $2^{\mathrm{a}}$ ed. Porto Alegre: Editora Globo, 1974. pp, 34).

${ }^{260}$ LOBATO, M. O Choque das Raças. A Manhã: Rio de Janeiro, 05 de setembro de 1926, ano II, n. 215 , p. 1.

${ }^{261}$ Idem.
} 
Ayrton Lobo segue, nesse primeiro momento, se descrevendo como "um pobre diabo para toda a gente" ${ }^{, 62}$, que vivia do seu trabalho como servidor da firma Sá, Pato \& Companhia, e recentemente "curado de jogatinas" ${ }^{263}$. Ele sempre sonhara em comprar um automóvel, pois via a humanidade divida em duas castas, a dos pedestres e rodantes. Pertencente à classe dos pedestres, almejara ascender a dos rodantes. Desta forma, juntou certa quantia e conseguiu elevar-se "socialmente", comprou a máquina que mudara sua situação social, um Ford.

Os efeitos dessa compra foram decisivos na minha vida. Ao verem-me chegar ao escritório fonfonando, os patrões abriram as maiores bocas que ainda lhes vi e vacilaram entre porem-me no olho da rua ou dobrarem-me o ordenado. Por fim, dobraram-me o ordenado, quando demonstrei o quanto lhes aumentaria o renome da firma o terem um auxiliar possuidor de automóvel próprio. ${ }^{264}$

A posse do automóvel trouxera-lhe prestígio no trabalho e uma certa "ascensão social"265. Assim, orgulhoso de sua conquista e progresso, adquire a "mentalidade dos rodantes, passando a desprezar o pedestre como coisa vil e de somenos importância na vida" ${ }^{266}$. Porque agora, rodante, podia desfrutar do $\operatorname{status}^{267}$ que ele próprio designara aos possuidores de automóvel, "homem superior que não anda, mas desliza veloz"268. Curioso observar que tal mudança, de fato, ocorreu com o próprio Monteiro Lobato, confirmando a tese de Antônio Cândido e Forster de que muitas vezes as personagens refletem a personalidade de seu criador $^{269}$. Em carta endereçada a Rangel, três anos antes da publicação do romance, o autor conta que comprou um Ford e descreve sua sensação diante de sua mais nova aquisição.

Depois da mudança meti-me em automobilismo. Comprei um Ford e já ando a perturbar o trânsito da cidade. Ontem dei o primeiro tranco numa carroça, mas ainda não esmaguei nenhum pedestre. Curiosa a mudança de mentalidade que o automóvel ocasiona. O pedestre passa a ser uma raça vil e desprezível, cuja única função é

\footnotetext{
${ }^{262}$ Idem.

${ }^{263}$ Idem.

264 Idem.

${ }^{265}$ De acordo com H. U. Gumbrecht, os automóveis grandes de 1926 podiam servir como símbolo de status social "porque se parec[ia] com uma versão levemente modificada de uma carruagem a cavalo particular - isto é, com uma relíquia de dias menos igualitários". (Cf. GUMBRECHT, Hans Ulrich. Em 1926: vivendo no limite do tempo. Tradução de Luciano Tiago. Rio de Janeiro: Record, 1999. pp. 45-46)

${ }^{266}$ LOBATO, M. O Choque das Raças. A Manhã: Rio de Janeiro, 05 de setembro de 1926, ano II, n. 215 , p. 1.

${ }^{267}$ Segundo as propagandas da Ford, em 1920, um "Coupelet" de partida elétrica e rodas desmontáveis custava 4:820\$000; um "Double Phaeton" para 5 pessoas, 3:690\$000; e um "Voiturette" para 2 pessoas, 3:30\$000. (Cf. Ford: o automóvel universal. Correio da Manhã: Rio de Janeiro, 01 de janeiro de 1920, ano XIX, n. 7.612, p. 16. Disponível em: <http://memoria.bn.br/DocReader/docreader.aspx?bib=089842_03\&PagFis=1>. Acesso em janeiro 2015.

${ }^{268}$ LOBATO, M. O Choque das Raças. A Manhã: Rio de Janeiro, 05 de setembro de 1926, ano II, n. 215 , p. 1.

${ }^{269}$ FORSTER, E. M. op. cit. p. 51; CÂNDIDO, Antônio. A Personagem do Romance. In: CÂNDIDO, Antônio [et. Al]. A Personagem de Ficção. São Paulo: Perspectiva, 1968, p. 65.
} 
atravessar as ruas. Quem adquire auto promove-se de 'pedestre' a 'rodante' - e passa a desprezar os miseráveis pedestres que se arrastam pelas superfícies, como lagartas. Quando estropia um pedestre, a sensação do rodante é de que libertou o mundo de um embaraço. ${ }^{270}$

Essa declaração, primeiramente entre amigos, vai de encontro com a visão formulada por Ayrton em $O$ Choque. Demonstra que Lobato se valia, de alguma forma, da sua experiência pessoal para escrever suas obras literárias. Note que não queremos com isso dizer que toda obra literária é $100 \%$ real, inteiramente baseada nas experiências pessoais do autor, nem que todo escritor, poeta ou literato é simplesmente um "foco refletor" de sua sociedade. Almejamos demonstrar que há um processo de "gestação" de ideias, no qual o escritor vivência e analisa seu contexto social para depois formular suas ideias a partir de sua visão individual. Essa consciência, que o leitor de Lobato em princípio desconhecia, pode sugerir ser o narrado uma espécie de álter ego do próprio Lobato, alguém também convertido à eugenia. A sugestão do nome também dá substância a essa hipótese.

Assim, ainda no primeiro capítulo, Ayrton Lobo conhece o Professor Benson e sua filha, Miss Jane, a partir de um inusitado encontro, fruto das "injunções do acaso",271. Encarregado de ir "liquidar pessoalmente certo negócio com um freguês morador perto de Friburgo" "272, e distraindo-se com os "formosos quadros da natureza", Ayrton Lobo sofre um acidente de carro. Por ironia do destino (ou não), o senhor de quem Ayrton e seu amigo corretor, no início do romance, conversavam - o velho jogador de câmbio implacável - é quem the socorre e lhe dá abrigo. Inicia-se, assim, um relacionamento que o levará ao processo de introdução - do mesmo modo que os leitores - às teorias eugênicas. $\mathrm{O}$ caráter pedagógico se fará desde o início, mas é, sobretudo, a partir desse encontro que ele fica mais evidente. Começa agora os ensinamentos de professor Benson a Ayrton Lobo.

A passagem do acidente de automóvel nos faz pensar no primeiro indício apresentado sobre a capacidade de Ayrton Lobo conseguir progredir e de saber economizar. Ele era um "um pobre diabo",273 que sobrevivia com um pequeno salário, mas que, durante quatro ano, poupou e conseguiu comprar um Ford ${ }^{274}$. Mais do que sugerir pistas sobre a personalidade deste personagem, esse trecho chama atenção porque encontrarmos centenas de notícias nos jornais da época sobre a "popularização" dos automóveis e os diversos acidentes ocorridos

\footnotetext{
${ }^{270}$ LOBATO, M. A Barca de Gleyre... (t. 2), p. 259. Carta de 10.09.1923.

${ }^{271}$ LOBATO, M. O Choque das Raças. A Manhã: Rio de Janeiro, 5 de setembro 1926, ano II, n. 215 .p. 5.

${ }^{272}$ Idem.

273 Ibidem, p. 1.

${ }^{274}$ Idem.
} 
desde então. Podemos questionar se Lobato escolheu propositalmente o acidente como catalisador do encontro entre as personagens. Estaria ele apontando para mais um assunto corriqueiro (os acidentes de automóveis), ou o fez de forma inconsciente, sem pensar numa leitura crítica por parte dos seus leitores?

Os números chamam atenção: na Gazeta de Notícias há, só no mês de agosto de 1926, 76 ocorrências; e no Correio da Manhã, no mesmo período, são 143 ocorrências. A Manhã, por outro lado, apresenta um número menor de ocorrências entre o período de julho e setembro: 35. Os textos variam entre propagandas, notícias de acidentes e informações automobilísticas. Na Gazeta há uma Seção denominada Automobilismo, a qual é dedicada aos apaixonados por carro. Há textos sobre os cuidados que devem ser tomados ao lavar o automóvel, inovações tecnológicas, corridas automobilísticas, venda de carros usados, dentre outros. Para nós, se destacam as notícias de acidentes que, segundo Gumbrecht ${ }^{275}$, se davam, na grande maioria das vezes, devido à "desproporção entre a tração e o desempenho do motor", tornando, assim, os automóveis daquela época perigosos. Os jornais e revistas de outros países também estavam repletos de relatos de acidentes de automóveis. O que, mais uma vez, demonstra que Lobato até no aparente e simples acidente de carro traz acontecimentos do contexto social para o romance. Essas passagens comprovam o fascínio do literato com os automóveis e seu conhecimento sobre preço e acidentes com carros. Ao que parece, a ideia de Lobato era chamar atenção (mesmo que em forma de sátira) à crescente disseminação dos veículos entre as camadas sociais e, consequentemente, ao aumento de acidentes nas cidades.

Lobato cria uma situação aparentemente catastrófica para unir as personagens. Assim, ocorrido o acidente, Ayrton é socorrido pelos empregados de Benson e chega a ficar durante "quinze ou vinte dias" 276 em seus aposentos. Ao se recuperar do acidente, pede ao proprietário que lhe dê um emprego, pois, afastado de sua firma todos esses dias e agora sem automóvel, era provável que seus patrões tivessem diminuído o seu ordenado, caso ainda não o tivessem demitido. Professor Benson, sensibilizado com o pedido e consciente de seu estado crítico de saúde e breve morte, decide tomá-lo como confidente, pois acreditava que a sua inesperada "visita" tinha algum sentido de ser. Acreditando na obra do destino, Benson decide revelar-lhe seu grande segredo. Diz preferir ter em seu lugar um sábio como confidente, mas decide não

\footnotetext{
${ }^{275}$ GUMBRECHT, Hans Ulrich. op. cit., p. 46.

${ }^{276}$ LOBATO, M. O Choque das Raças. A Manhã: Rio de Janeiro, 5 de setembro 1926, ano II, n. 215 .p. 5.
} 
ir contra ao "Acaso",277, pois já que "Ele o trouxe ao meu encontro, seja pois o meu confidente" 278 .

Professor Benson decide, então, levar Ayrton, "homem comum" e "inocente"279, para conhecer o seu laboratório e sua principal descoberta: o Porviroscópio. Segundo o professor, a história e o tempo já estavam pré-determinados, pois, segundo ele, eram como um livro já escrito e aberto $^{280}$ : a página aberta, o presente; as páginas passadas, o passado; as subsequentes, o futuro. Uma vez que o tempo e a vida já estavam escritos e predestinados, o Porviroscópio conseguia ler as páginas do futuro.

Essas revelações são expostas de forma simples e pedagógica, por meio de exemplos e questionamentos de fácil compreensão. Afinal, a figura do sábio, representava também um artifício do autor para doutrinar os leitores d'A Manhã. Conforme o professor apresenta seu gabinete e laboratório, e expõe as ideias filosóficas e científicas que o inspiraram a construir sua máquina do tempo, Ayrton começa a se deparar com alguns conflitos internos. A áurea científica e superior que pairava em torno de tudo e de todos naqueles aposentos, e a enxurrada de novos conhecimentos, começavam a mexer com o seu íntimo, trazendo-lhe um novo horizonte de expectativas.

Afeito que estava a viver em cidade e, sobretudo, nas ruas, aquele silêncio e aquela solidão punham-me novidades n'alma. Senti no cérebro um referver de ideias novas, a saírem da casca como pintos. ${ }^{281}$

Entendemos esse "referver de ideias novas" como um despertar de consciência. Ayrton começava a dar atenção a coisas, aparentemente, pequenas, como o silêncio. O contato com ideias diferentes daquelas reproduzidas pelos seus patrões e amigos começava a fazer sentido. Ao longo da narrativa iremos perceber que esse personagem sofrerá uma transformação psicológica, e pouco a pouco irá incorporar os preceitos eugênicos. Ayrton, em um primeiro momento, se encontra na história na mesma posição que alguns leitores: leigo no assunto, porém curioso e questionador. Ledo engano se acharmos que sua transformação se dará de forma espontânea. Benson e Miss Jane são as personificações dos eugenistas, os intelectuais conhecedores da ciência, e, portanto, os instrutores rumo ao caminho da

\footnotetext{
${ }^{277}$ Idem.

${ }^{278}$ Idem.

${ }^{279}$ Idem.

${ }^{280}$ GIROLDO, R.; SANTOS, R. C.Z. Transfigurações utópicas em O Presidente Negro de Monteiro Lobato. Disponível em<http://www4.pucsp.br/revistafronteiraz/numeros_anteriores/n4/download/pdf/lobato.pdf $>$. Acesso em janeiro de 2016.

${ }^{281}$ LOBATO, M. O Choque das Raças. A Manhã: Rio de Janeiro, 5 de setembro 1926, ano II, n. 215. p. 5.
} 
emancipação social. É pela identificação do leitor com essas personagens que Monteiro Lobato pretende convencer o público às ideias eugênicas.

É grande a quantidade de informação nos primeiros capítulos, Ayrton (e os leitores) chega a ficar cansado e confuso com o desenrolar da narrativa. Até o capítulo V - ainda no primeiro dia de publicação -, Benson não chega a revelar de fato a sua invenção. Lobato termina o longo primeiro dia de publicação com Benson revelando que descobriu um jeito de prever o futuro. Os leitores, portanto, tiveram que dormir com essa inquietação. Afinal, o que será que o Professor tinha descoberto? Lobato soube explorar muito bem as pausas diárias do romance para instigar a curiosidade do leitor. Em cada desfecho traz um clímax, alguma ideia fica solta no ar, podendo ser captada somente no próximo dia.

Somente nos capítulos seguintes (VI e VII) ${ }^{282}$, com o desenvolvimento da narrativa e dos diálogos, Professor Benson vai, aos poucos, desvelando e explicando sua engenhoca. O Porviroscópio, por intermédio de alguns procedimentos e cálculos, permitia que qualquer um lesse e enxergasse o futuro, então já pré-determinado. Boquiaberto, Ayrton ouvia atento o seu falatório, porém, foi outra novidade que veio lhe roubar a atenção. Entre as conversas e indagações com Benson, eis que surge em cena sua filha, Miss Jane. Loira, de olhos azuis e com uma beleza estonteante, Ayrton se encanta com tamanha graciosidade em forma de mulher. Até agora nenhuma informação científica ou filosófica tinha conseguido chamar tanto a sua atenção como a bela moça. A entrada de Miss Jane é triunfal e arrebatadora para Ayrton. Se ele já estava confuso com tantos conhecimentos novos, agora seu coração era tomado pela paixão e sua mente perturbava-se ainda mais.

Até o capítulo VIII, A luz que se apaga, será o Professor Benson - modelo de eugenista, o "Deus humanizado" exaltado por Ayrton e Miss Jane como o tipo ideal de homem sábio, inteligente, simples, humilde e benevolente ${ }^{283}$ - que fará o doutrinamento de Ayrton. Ele testa e atesta as capacidades intelectuais de seu novo pupilo diante de um turbilhão de novos conhecimentos. O professor somente revela novas informações conforme a personagem ia demonstrando interesse e compreensão por aquilo que estava sendo dito.

Parece que o professor Benson mudou de ideia que formava de mim. Viu que o discípulo aprendia depressa e, voltando atrás, como se valesse a pena instruí-lo mais a fundo, passou a explicar-me dezenas de coisas do seu laboratório, na intenção de

\footnotetext{
${ }^{282}$ O Tempo Artificial e Futuro e Presente.

283 "Diante do comendador Pato eu tremia e balbuciava; mas diante do professor Benson, um deus, sempre em senti como em face de um igual. Compreendo hoje o fenômeno e sei que a verdadeira superioridade num homem não o extrema dos 'inocentes', como dizia o professor [...].”. Idem.
} 
confirmar-me nos princípios que o levavam à dedução da fórmula: Éter + Interferência $=$ Vida. ${ }^{284}$

Uma pausa necessária. Esse princípio, segundo Benson, regia a vida humana na terra, e, também constituía o padrão de funcionamento de sua máquina do tempo. Ela resumia o modo operacional do universo. O Interferente (Deus) interviu só uma vez, e, a partir disso, o "fenômeno vida, que também podemos denominar universo, desenvolveu-se por si, automaticamente, por determinismo",285. Assim, as coisas iam "se determinando...,286. Pela leitura do romance, Monteiro Lobato deixa entrever que essa fórmula podia sofrer outras ingerências, porque, embora o primeiro Interferente já tivesse atuado, o homem havia corrompido a lei regente desse paradigma. Ao cruzar raças distintas sem levar em consideração a prática da seleção natural, o homem maculou sua espécie. Para retornar ao equilíbrio inicial, a proposta é intervir novamente por meio da ciência. Amparados pelos saberes da razão, cabia ao homem tomar o controle do princípio Éter + Interferência = Vida e reestabelecer a harmonia. A ciência, portanto, podia alterar o futuro, a Vida, e, principalmente, os rumos do Brasil.

Em doses homeopáticas, Benson instrui o leigo Ayrton sobre os princípios e as teorias científicas que estavam em voga no início do século XX e que constituíam os pilares básicos da eugenia. Até mesmo a concepção da máquina e seu funcionamento expressavam as ideias deterministas, em consonância com a lógica eugenista. Encontramos nesse trecho, por exemplo, a crença no determinismo, um dos preceitos da ciência do dia. Característica principal do movimento eugenista brasileiro, a adesão às teses de Lamarck, o neolamarckismo ${ }^{287}$, foi preponderante no pensamento científico latino-americano. $\mathrm{O}$ determinismo geográfico - teoria que via o desenvolvimento cultural de uma nação completamente condicionado ao meio em que se vive - constitui apenas uma das correntes que ganharia espaço no Brasil no final do século XIX e início do século $\mathrm{XX}^{288}$. Buscando

\footnotetext{
${ }^{284}$ Idem.

285 Idem.

${ }^{286}$ Idem.

287 Depois das descobertas de Mendel, em 1900, o lamarckismo passou a significar uma teoria sobre o funcionamento da hereditariedade. Nancy Stepan descreve muito bem esse movimento científico e suas transições, analisa sua repercussão na América Latina e, especialmente, no Brasil. (Cf.: capítulo 3, "Venenos raciais e a política da hereditariedade na América Latina na década de 1920”. Nancy Leys Stepan. A Hora da Eugenia: raça, gênero e nação na América Latina. RJ: Fiocruz, 2005)

${ }^{288}$ SCHWARCZ, Lilia Moritz. O espetáculo das raças: cientistas, instituições e questão racial no Brasil, $1870-$ 1930. São Paulo: Companhia das Letras, $7^{\mathrm{a}}$ reimpressão, 2007, p. 58.
} 
explicar as diferenças sociais internas no país, o discurso determinista, juntamente com o evolucionista, passava a explicar o atraso e a inferioridade brasileira ${ }^{289}$.

As teses deterministas juntamente com as evolucionistas foram utilizadas para tentar explicar o atraso e a inferioridade brasileira ${ }^{290}$. As diferenças sociais começaram a ser analisadas a fim de entender e justificar a sujeição de algumas personificações (negros e deficientes, por exemplo). Os argumentos científicos utilizados outrora para justificar algumas políticas que visavam acabar com as diferenças internas, por fim corroboravam conceitos racistas e legitimavam os discursos em prol de uma superioridade racial, dando corpo assim aos preceitos das teorias e crenças eugênicas.

Pautado nessas premissas, Lobato se dispõe a corroborar algumas dessas concepções em $O$ Choque das Raças. Atribuiu às personagens intelectualmente superiores a missão de doutrinação de Ayrton Lobo que passa por uma espécie de processo de seleção artificial empreendido pelo professor e sua filha. Por essa razão, e também para garantir que os leitores acompanhassem a lógica do argumento, os conhecimentos sobre eugenia são lançados à conta gotas. Conforme o seu interlocutor demonstrava compreender as ilustrações, Benson seguia revelando novos conhecimentos. Observe que Ayrton já se vê como discípulo de seu novo mestre, o homem mais sábio que já conhecera. Importante também considerar que outrora Ayrton era visto pelo professor como um "homem simples" e sem estudos. Agora, porém, constatava que o seu aprendiz conseguia e podia ir além do que inicialmente podia supor:

- Muito bem, está compreendendo. Vejo que o nosso amigo possui uma inteligência natural, embora inculta. ${ }^{291}$.

O aprendizado rápido e o senso crítico do rapaz passam a chamar a atenção do professor que começa a admirá-lo. Ora, Ayrton era inteligente, só não tivera a oportunidade dos estudos e tampouco de explorar seu intelecto da melhor maneira possível ${ }^{292}$. Suas aptidões e habilidades estavam adormecidas, e era necessário despertá-lo ao conhecimento por meio do ensino. A eugenia servia também para revelar esses tipos de homens comuns,

\footnotetext{
${ }^{289}$ Idem.

${ }^{290}$ Segundo Lilian Schwarcz, “A eugenia não apenas representava a política social desse modelo determinista, como revelava as incompatibilidades existentes entre evolucionismo cultural e darwinismo social". Ibidem, p. 61.

${ }^{291}$ LOBATO, M. O Choque das Raças. A Manhã: Rio de Janeiro, 5 de setembro 1926, ano II, n. 215 . p. 5.

292 Como veremos adiante, a eugenia positiva acreditava que todos tinham um tipo de inteligência. Uns eram mais inteligentes que outros, porém a falta de acesso à educação e à informação acabava por não despertar a semente da sabedoria. Cabia, portanto, aos eugenistas, descobrir e aflorar o intelecto das pessoas ditas superiores racionalmente. Ayrton, como pode-se ver, era um desses, tinha a inteligência adormecida, e, com a ajuda de Benson e Miss Jane, irá revelar-se um homem sábio.
} 
porém superiores. Deste modo, aos poucos, o sábio professor vai desvelando os mistérios de sua invenção e ensinando-lhe como era possível transitar entre o passado e o futuro.

No capítulo VIII, Professor Benson começa a se sentir fraco. Muito atarefado e enfraquecido, não consegue acompanhar Ayrton em sua jornada ao futuro, e delega a sua filha a tarefa de prosseguir os ensinamentos até então ministrados por ele sobre o Porviroscópio. Pede para que Miss Jane se atenha mais aos relatos do futuro do que as explicações em si sobre o funcionamento da máquina. Assim, a moça conta histórias do que viu no futuro, como o desaparecimento dos automóveis e da roda, e o surgimento do rádio-transporte.

- [...] quantas revelações curiosas! Outra que muito me impressionou foi a transformação das ruas que se nota no ano $2.200 \mathrm{em}$ diante. Cessa a era dos veículos. Nada de bondes, automóveis, aeroplanos.

- Como pode ser isso, Miss Jane? É quase um absurdo.

- Pois para lá caminhamos. Em cortes sucessivos que fiz de dez em dez anos observei a diminuição rápida dos veículos atuais. A roda, que foi a maior invenção mecânica do homem e hoje domina soberana, terá o seu fim. O homem voltará a andar a pé. O que se dará é o seguinte: o radio transporte tornará inútil o corre-corre atual. $^{293}$

Segundo Miss Jane o surgimento do rádio-transporte tornaria obsoletos alguns mecanismos de transportes. A roda, por exemplo, seria artigo de curiosidade em museus. "Filha da raça mais nobre do mundo, oriunda do sangue mais puro"294, a personagem começa a desempenhar um papel de destaque na narrativa. Ganha respeito e admiração de Ayrton não só pela beleza, mas, também, pela inteligência e postura sábia. Diferente das mulheres daquela época, possuía "frieza de sábio"295, era igual ao pai. Ela é a personificação da ciência, e, mais especificamente, da eugenia.

Enquanto relatava os acontecimentos do futuro a Ayrton Lobo, seu pai destruía a máquina do tempo. O sábio acreditava que a humanidade não encontrava-se em condições para lidar com a maior invenção de todos os tempos, o Porviroscópio. Assim, no capítulo $A$ luz que se apaga, o Professor Benson vem a falecer ${ }^{296}$, deixando a Miss Jane a tarefa de narrar os fatos vistos e estudados por ela ao seu pupilo. Deste modo, encerra o quinto dia de publicação do romance. A morte do professor e a destruição da máquina do tempo, provavelmente, ficaram na mente dos leitores. Afinal, o que poderia acontecer de agora em

\footnotetext{
${ }^{293}$ LOBATO, M. O Choque das Raças. A Manhã: Rio de Janeiro, 9 de setembro 1926, ano II, n. 218. p. 5.

${ }^{294}$ Idem.

${ }^{295}$ Capitulo 14

${ }^{296}$ A morte do Professor Benson é repentina. Sentindo-se fraco, decide destruir o Porviroscópio e, em sequência, morre. Lobato não explora as causas de sua morte, Benson simplesmente vem a falecer para dar lugar e espaço a história de Ayrton Lobo e Miss Jane.
} 
diante? Por que o professor não confiou em deixar sua invenção como legado a Miss Jane? Será por que ela era uma mulher? Se Ayrton ainda tivera o prazer de ver os seus "cortes anatômicos", como prosseguiria a história depois dessa notícia alarmante?

Nos dias seguintes, sem o seu mestre, Ayrton vê-se na necessidade de retornar a sua antiga vida. Miss Jane, embora de luto, diz que dará sequência a tarefa que lhe foi outorgada. Assim, além de contar sobre as curiosidades do futuro, a nossa sábia e racional jovem, começa a, de forma sutil, comparar o Brasil com as visões que tivera do porvir norteamericano, e, de forma ainda incipiente, começa a falar sobre raça e as teorias racialistas. Em sua concepção, um dos fatores que contribuiria para o sucesso futuro do Brasil seria a divisão do país pelo clima. Dizia que em 2228, o Brasil havia segregado-se em dois países, "um centralizador de toda a grandeza sul-americana, filho que era do imenso foco industrial” ${ }^{, 297}$, e “outro, uma república tropical, [que] agitava-se ainda nas velhas convulsões políticas e filológicas" ${ }^{, 298}$. Na região Centro-sul ficariam os mais instruídos e evoluídos, para o Norte seriam levados todos aqueles que apresentavam algum tipo de degeneração genética e/ou social, pois essa região era "reflexo do desequilíbrio sanguíneo consequente à fusão de quatro raças distintas, o branco, o negro, o vermelho e o amarelo" ${ }^{299}$. Miss Jane, a encarnação da eugenia, tenta convencer Ayrton de que a divisão do país havia constituído a melhor solução possível:

- Acho até que a divisão do país constituiu uma solução ótima, a melhor possível,
dado o erro inicial da mistura das raças. A parte quente ficou a sofrer o erro e suas
consequências; mas a parte temperada salvou-se e pôde seguir o caminho certo. A
sua tristeza vem da ilusão territorial. Mas reflita que a muita terra não é que faz a
grandeza de um povo e sim a qualidade dos seus habitantes. ${ }^{300}$

A revelação do futuro de um país dividido em trópicos chocara Ayrton, até então ingênuo quanto às questões eugênicas. "Não pude deixar de estremecer diante da revelação que miss Jane fazia do futuro do meu país" ${ }^{301}$. Contudo, a moça não via motivos para tamanha desconsolação do rapaz. A qualidade sobrepujava a quantidade. O "erro inicial", a miscigenação, seria solucionado pela divisão da sociedade a partir do clima e dos modelos sociais. Apesar do processo de "restauração" da sociedade brasileira ser inevitável, cabia aos sanitaristas e eugenistas racionalizar e apressar esse acontecimento. O brado era agir com

\footnotetext{
${ }^{297}$ LOBATO, M. O Choque das Raças. A Manhã: Rio de Janeiro, 14 de setembro 1926, ano II, n. 222 . p. 5.

${ }^{298}$ Idem.

${ }^{299}$ Idem.

${ }^{300}$ Idem.

${ }^{301}$ Idem.
} 
antecipação, "fazer a eugenia e não esperar pela seleção natural" ${ }^{302}$, tendo em vista que o meio era determinante na constituição física e moral do homem.

O conteúdo racista, eugenista e misógino vai se revelando ao longo da narrativa, principalmente, a partir do capítulo XI, No ano 2228. Miss Jane decide, então, narrar detalhadamente o fato apresentado pelo Porviroscópio que mais lhe surpreendeu Descreve ao seu aluno o "formidável" choque das raças branca e negra nos Estados Unidos, no ano 2228. No entanto, havia um preço para a revelação. Ayrton Lobo precisava relatar sobre tudo o que lhe seria revelado. Tinha, portanto, a missão de escrever um livro.

Ora, eu fornecerei os dados dessa novela e o senhor Ayrton terá oportunidade ótima
para apresentar-se ao mundo das letras com um livro que a crítica julgará ficção,
embora não passe da simples verdade futura. ${ }^{303}$

O seu romance futurista estava fadado a ser julgado por seu público como uma mera ficção. De alguma maneira, o destino literário de Lobato e de Ayrton pareciam convergir para o mesmo caminho. A manifestação do choque entre as raças pelas lentes da eugenia certamente causaria incredibilidade. Por essa razão, o literato utilizou-se de uma fórmula narrativa pautada no determinismo, pois, assim, estaria apenas revelando a "verdade futura" e inevitável para os seus leitores.

Feito o acordo, todos os domingos Miss Jane revelava a Ayrton uma parcela da "dramática"304 história do conflito entre a raça branca e negra. O relato da personagem é longo e detalhista, portanto, iria requer inúmeros encontros. Nesse momento da narrativa, os desfechos diários do jornal trazem certas tensões e curiosidades. No dia doze de setembro de 1926, por exemplo, a narrativa encerra quando Miss Jane começa a explicar as consequências da ciência de Galton nos EUA. O leitor, certamente, fica curioso para saber desses resultados. Ora, esse assunto era alvo de discussões naquele tempo. $\mathrm{O}$ debate em torno das questões raciais e da miscigenação estavam a todo vapor, mobilizando pessoas de diferentes áreas do saber e de diferentes camadas sociais, ocupando, assim, destaque em vários periódicos.

Ao contar a história do choque das raças em 2228, Lobato utiliza Miss Jane para demonstrar ao seu leitor o quão nefasta foi a inserção do elemento negro naquele país e, consequentemente, no Brasil. “- Entrou o negro e foi esse o único erro inicial, cometido

\footnotetext{
${ }^{302}$ KEHL apud SOUZA, Vanderlei Sebastião de. Em nome da raça... p. 56.

${ }^{303}$ LOBATO, M. O Choque das Raças. A Manhã: Rio de Janeiro, 14 de setembro 1926, ano II, n. 222 . p. 5. ${ }^{304}$ Idem.
} 
naquela feliz composição"305. Trechos inquietantes como este, bem como outras passagens do romance, nos levam a refletir sobre o grande "problema" social das primeiras décadas do século XX. Fica evidente nessa passagem que Miss Jane acreditava ser a miscigenação prejudicial para o futuro de uma nação, e que estava respaldada por ideais da eugenia negativa.

Cada período relatado por Miss Jane pode ser associado a diferentes "cortes anatômicos". Todos os temas se relacionam uns aos outros, levando os leitores a refletirem sobre o futuro das sociedades que colocam em prática a "sábia ciência", e daquelas que persistem cometendo o mesmo erro inicial, não implantando a verdadeira solução que curava a semente do presente para então germinar o futuro. $O$ processo de restauração social, aplicado na narrativa por Monteiro Lobato, visava o aprimoramento e conservação dos bons caracteres e a eliminação dos degenerados.

Uma construção literária é fruto de um contexto social e reflexo da personalidade de seu autor, o que acaba por constituir e moldar as personagens de um romance. O Choque das raças, assim sendo, dialoga com as tensões e conflitos sociais e políticos dos nada calmos anos $1920^{306}$. Da maneira mais geral, $O$ Choque trata da promoção e implementação da "ciência do dia", isto é, das ideias eugênicas, da higienização do povo e do país, de um movimento científico e social. De forma emblemática, adjetivos como "bem nascido", "tipo bom", degenerado e raça superior, são lançados ao longo da narrativa por Lobato como sementes que precisam germinar para florescer. As formas de apropriação do aprimoramento racial são discutidas pelas personagens na narrativa a partir de um modelo: os Estados Unidos. Esse país, na realidade e na ficção de Lobato, era o grande precursor da eugenia na América. O sucesso dessa ciência por lá era tanto que, em 1903, foi fundada a primeira sociedade eugênica norte-americana: a Associação Americana de Reprodução ligada à Associação Americana de Agricultura, sediada em Saint Louis ${ }^{307}$. De acordo com Diwan, a eugenia ganhou poder e foi utilizada como "arma política de discriminação social e limpeza étnica"308 nesse país, bem como em diversos outros da Europa.

Valendo-se da experiência deste país, Monteiro Lobato, na voz de Miss Jane, almejava convencer os leitores dos benefícios empreendidos pela eugenia. A partir do capítulo XIV,

\footnotetext{
${ }^{305}$ LOBATO, M. O Choque das Raças. A Manhã: Rio de Janeiro, 23 de setembro 1926, ano II, n. 230. p. 5.

${ }^{306}$ QUELUZ, Gilson Leandro. op. cit., p. 242.

307 DIWAN, Pietra. Raça Pura. Uma história da eugenia no Brasil e no mundo. Editora Contexto: São Paulo, 2007.p. 44

${ }^{308}$ Idibem, p. 46.
} 
Ayrton, já então convencido, não mais questiona a história contada por sua encantadora professora, como o fez ao longo dos primeiros capítulos. Já persuadido dos ideais eugênicos e das soluções encontradas pela raça branca, passa agora a se questionar da lentidão e do esmorecimento da sociedade brasileira em implementar os preceitos da ciência do dia.

Mais do que convicto dos ideais eugênicos, Ayrton Lobo transforma-se psicologicamente e desenvolve um senso crítico semelhante ao de Miss Jane em relação à realidade brasileira. Ao retornar a sua rotina de servidor, não mais consegue se identificar com a figura fanfarrona, capitalista e egoísta de seus patrões como outrora. O moço começa a sentir as transformações íntimas e pessoais geradas com os novos conhecimentos adquiridos sobre o futuro. Da mesma forma, um novo olhar para o presente começa a ganhar força.

Parece incrível a transformação que se operava em mim! Vinte dias antes não
passava de humilde empregado de rua, e estava agora na iminência de tornar-me
autor de um livro capaz de assombrar os pósteros com as suas revelações e de
imortalizar meu nome séculos mais tarde! $!^{309}$

De um simples servidor da firma Sá, Pato \& Cia, Ayrton passara a deslumbrar seu futuro como escritor de um livro "capaz de assombrar os pósteros". Não nos parece descabido imaginar a figura de Lobato nas falas de Ayrton. É bem provável que Lobato acreditava no sucesso de $O$ Choque e na forma positiva como ele seria recebido pelo público. Ora, como ele mesmo dizia, não estava falando de "futurinho de 50 anos", mas sim de mais trezentos anos, repletos de revelações e acontecimentos capazes de abalar o presente. Essa sensação do já conhecido seria capaz de criar um sentimento de identificação nas mentes e corações de seus leitores. A narrativa desse romance trabalha esse aspecto de forma muito interessante. Toca nos pontos nevrálgicos da sociedade brasileira de forma sutil e, ao mesmo tempo, abrupta.

Lobato construiu uma história na qual brancos e negros lutam em defesa da primazia de seu sangue, a favor da eugenia e em proveito próprio. O enredo, além de ser composto por espaços temporais duplos (presente e futuro) se desenvolve em dois países americanos, o Brasil e os Estados Unidos. Essa escolha de narrativa foi muito bem delineada a fim de incitar um debate entre os brasileiros. Ela tem uma razão de ser e é pura determinação do autor. Ao colocar Miss Jane no papel de "educadora”, Lobato concede-lhe o poder da verdade e certeza. A história fictícia, repleta de curiosidades e fantasias criativas de Lobato, traz em sua trama elementos da realidade brasileira e dos contextos histórico, político e social vivenciados no momento.

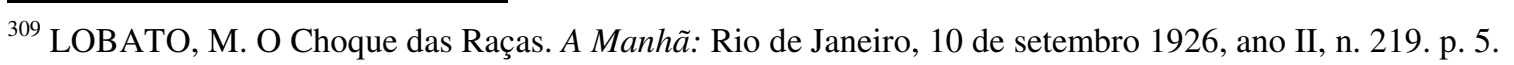


Nessa parte, na descrição dos Estados Unidos do presente de 1926, Miss Jane faz Ayrton Lobo refletir também sobre o presente do Brasil. Embora vanglorie a todo o tempo os americanos e suas políticas sociais, reconhece a existência de um infortúnio histórico. Ainda que modelo ideal de Estado organizado e bem-sucedido, havia um elemento que prejudicava o desempenho dos EUA. Era "o erro inicial”, “o caroço no sapato": o negro.

- Erro impossível de ser corrigido - aventurei [Ayrton]. - Nós aqui também tivemos
igual problema, mas a tempo acudimos com a solução prática - e por isso, Miss
Jane, penso que somos inda mais pragmáticos do que os americanos. A nossa
solução foi admirável. Dentro de um século ou dois o nosso negro terá desaparecido
completamente, em virtude de cruzamentos sucessivos com o branco. Não acha que
fomos felicíssimos na nossa solução? [...]
- Não acho - disse ela. - A nossa solução foi medíocre. Estragou duas raças,
fundindo-as. O negro perdeu as suas admiráveis qualidades físicas de selvagem e o
branco sofreu a inevitável depressão de caráter, consequente a todos os cruzamentos
entre raças díspares. Caráter racial é uma cristalização que lentamente se vai
operando através dos tempos. O cruzamento perturba essa cristalização, liquefá-la,
torna-a instável. A nossa solução deu um resultado gris: somos um povo nem lá nem
cá... 310

A citação acima nos remete diretamente a um dos grandes debates sociais brasileiros das primeiras décadas do século XX, a miscigenação - um dos principais e mais debatidos temas do pós-abolição -, e nos demonstram como as teorias eugênicas se apropriaram deste assunto e propuseram soluções para o seu contingenciamento, de forma complementar, e, muitas vezes, divergentes. Nesta passagem é possível constatar a presença de duas das três principais teorias eugênicas: a positiva e a negativa ${ }^{311}$.

Ledo engano imaginar que o movimento eugênico possuiu apenas uma única vertente, com a qual todos consentiam sem questionamentos. Franco Reis ${ }^{312}$ classifica o movimento distinguindo três correntes diferentes. Segundo esse autor, havia, de um lado, o grupo mais conservador, os "racistas ortodoxos", "gobinistas de carteirinha", para o qual o branqueamento da raça era a única solução, e, portanto, propunham a esterilização dos "tipos degenerados". A segunda corrente, julgava ser o branqueamento um "processo natural e irreversível, sendo a própria miscigenação já a garantia e a visibilidade de seu bom andamento"313; já a terceira corrente acreditava que o saneamento e a educação eram

\footnotetext{
${ }^{310}$ LOBATO, M. O Choque das Raças. A Manhã: Rio de Janeiro, 12 de setembro 1926, ano II, n. 221. p. 5.

${ }^{311}$ No Brasil vemos a eugenia se ramificar e se dividir em três vertentes: a) preventiva - que via o saneamento e a educação como primordiais para o progresso e desenvolvimento brasileiro, devendo o governo investir e intervir nesses dois processos.; b) positiva - acreditava ser o embranquecimento um processo natural e irreversível, viam na miscigenação a garantia de um "futuro branco"; e c) negativa -"racistas ortodoxos", os quais viam o branqueamento da raça como a única solução do problema brasileiro, propunham, então, a esterilização dos "tipos degenerados". STEPAN, Nancy Leys. op. cit., 60.

${ }^{312}$ Apud HABIB, Paula A. B. B. op. cit., p. 46.

${ }^{313}$ Idem.
} 
primordiais para o progresso e desenvolvimento da nação, e o governo deveria investir e intervir nessas duas áreas. Este último grupo não acreditava que a raça negra era degenerada, apenas que estava entregue ao abandono das políticas do Estado. Uma boa educação, bons hábitos de higiene e cuidados médicos seriam suficientes para que a parcela opilada da população fosse salva.

Um movimento social e científico ${ }^{314}$, a eugenia ganhava espaço nos diferentes núcleos sociais e se adaptava aos anseios de cada um. A apropriação e amadurecimento dessas ideias fez com que Lobato assumisse uma nova postura em $O$ Choque. Percebemos que o caráter sanitarista e preventivo, evidentes na concepção do Jeca Tatu e reproduzido novamente na fala de Ayrton, não mais representará a sua expressão máxima. Aqui o controle, a exclusão, e, muitas vezes, o extermínio dos caracteres disgênicos dos não-aptos, dos "imperfeitos", dos "degenerados" e dos negros, ganha voz em suas palavras.

$\mathrm{Na}$ citação anterior, tanto a eugenia positiva pregada por Ayrton Lobo, como a negativa defendida por Miss Jane, compactuava com a ideia de que a raça branca era pura e superior à negra e à amarela. Embora considerem a inferioridade inata às "gentes de cor", cada um, à sua maneira, via na miscigenação uma alternativa diferente. Ayrton acreditava que a miscigenação era um mal necessário para se alcançar o embranquecimento racial, pois dentro de alguns anos ou séculos o cruzamento das diferentes raças tornaria a sociedade cada vez mais branca. Isso parecia inevitável tendo em vista os princípios das leis evolucionistas, nas quais os mais fortes sobrepujam os mais fracos. Já os eugenistas negativos acreditavam que a miscigenação extinguia as qualidades das raças, enfraquecendo a prole amalgamada. A professora era, portanto, contrária à mistura das raças e a favor de uma intervenção catalisadora a fim de acelerar o processo de branqueamento da sociedade e exclusão dos tipos degenerados.

Miss Jane estava convencida de que a única forma de se edificar um "caráter racial" era por meio de sucessivas medidas de exclusão racial, sobretudo, no que concerne ao não cruzamento entre as raças branca e negra. A mistura perturbava e dissolvia o melhor de cada linhagem. A instabilidade era, portanto, a principal característica da população brasileira, porque encontrara como solução para os seus problemas a miscigenação. Por isso, "somos um povo nem lá nem cá...”.

${ }^{314}$ STEPAN, Nancy Leys. Eugenia no Brasil, 1917-1940. In: HOCHMAN, Gilberto, ARMUS, Diego. Cuidar, controlar, curar: ensaios históricos sobre saúde e doença na América Latina e Caribe. Rio de Janeiro: Editora Fiocruz, 2004. p. 331. 
Enquanto os portugueses não hesitaram em misturar-se aos negros, com risco de produzir filhos mestiços, os anglo-saxões, zelosos da pureza de sua linhagem, guardaram o negro à distância, e somente o usaram como instrumentos de trabalho. É curioso e digno de nota que nem a passagem do tempo nem qualquer outro fator foi capaz de alterar essa primeira atitude dos norte-americanos, que mantêm a raça negra separada da branca até os nossos dias. O Brasil agiu diversamente. Os brancos estabeleceram uma raça de mestiços, que se encontra, hoje, espalhada por uma vasta extensão de território. ${ }^{315}$

Percebe-se que há certa consonância entre as falas de Miss Jane e de Batista de Lacerda no tocante à supremacia dos norte-americanos, resultado da não mistura entre raças. Essa falsa comparação era, segundo Skidmore, comum nos discursos de intelectuais do início do século XX a fim de explicar o processo de embranquecimento da população brasileira comparando com os Estados Unidos ${ }^{316}$. A interpretação equivocada estava no fato do não reconhecimento dos mestiços, conferindo-lhes a "categoria inferior dos "negros""317. A miscigenação nos EUA não era admitida por seus compatriotas e demais observadores porque todos qualificavam os mestiços como inferiores e os inseriam no grupo de somenos prestígio social. Ao levarmos em conta o posicionamento de Miss Jane diante as fervorosas discussões, e como a personagem assenhorou-se das teorias já pronunciadas por diversos autores, constatamos que Lobato estava em dia com as discussões raciais e sociais de sua época, e, principalmente, evidenciamos a sua postura pessoal frente ao debate eugênico. Isso demonstra que Lobato estava construindo um argumento sobre o intricado debate por meio da literatura.

A escolha dos Estados Unidos como modelo de inspiração para o romance não foi gratuita. Primeiramente, ela evidencia a admiração nutrida pelo escritor por esse país e sugere também que a eugenia nessas terras estava sendo colocada em prática. Por fim, aponta para um desejo lobatiano em publicar o romance por lá com vistas a colher os frutos de seu trabalho em dólares. De fato, em 1926, a eugenia era pauta política e prática médica nos EUA. Charles Benedict Daverport, o principal representante eugenista do país, era favorável à vertente negativa da eugenia e vinha implementando experiências na Cold Spring Harbor, Long Island. A partir de estudos sobre hereditariedade e evolução, incluía todos os tipos de comportamento e condições físicas patológicas numa estrutura altamente redutiva ${ }^{318}$.

\footnotetext{
${ }^{315}$ LACERDA, Batista de. apud SKIDMORE, T. E. Preto no branco. Tradução Donaldson M. Garschagen. $1^{\mathrm{a}}$ e. São Paulo: Companhia das Letras, 2012. p. 118.

${ }^{316}$ Ibidem, p. 117.

${ }^{317}$ Ibidem, p. 118.

${ }^{318}$ STEPAN, Nancy Leys. A hora da Eugenia... p. 188.
} 
Davenport acreditava que cada raça "tinha sua própria identidade biológica fixa", e que a mistura racial preservava as más características dos indivíduos inferiores ${ }^{319}$.

Além de corroborar com essas práticas, Lobato acreditava que, por compactuar com as mesmas ideias eugênicas norte-americanas, também obteria sucesso literário com a tradução de seu romance. Os constantes elogios às terras do Tio Sam revelam a esperança de Lobato em publicar o romance neste país, considerado por ele como exemplar das ideias eugênicas, e um verdadeiro exemplo nacionalista. Mais do que uma admiração, havia um desejo pessoal do literato em propagar seus trabalhos e a "certeza" de publicação do $O$ Choque nos Estados Unidos. Monteiro Lobato escreveu essa obra antes de sua nomeação como Adido Comercial $^{320}$ do governo brasileiro nas terras do Tio Sam. Porém, já ambicionava sua publicação nas terras norte-americanas antes mesmo de sua efetiva produção:

Sabe o que ando gestando? Uma ideia-mãe! Um romance americano, isto é, editável
nos Estados Unidos. Já comecei e caminho depressa. Meio à Wells, com visão de
futuro. O clou será o choque da raça negra com a branca, quando a primeira, cujo
índice de proliferação é maior, alcançar a branca e batê-la nas urnas, elegendo um
presidente negro! ? $^{321}$

Lobato já tinha pronta a sua história e contava ao seu amigo Rangel dois meses antes de sua publicação. A "inteligência do branco" é uma das grandes protagonistas dessa obra, e a solução branca, a heroína nacional. A escolha dos Estados Unidos para ser o palco de apresentação das teorias eugenistas vai além de seu papel de destaque como executor máximo dessas medidas profiláticas. O desejo de publicação nas terras norte-americanas também se fazia presente. As próprias chamadas do romance no jornal já anunciavam o interesse de um Publisher americano pela obra.

'O choque das raças' aparecerá, daqui a quatro meses, simultaneamente, nos Estados Unidos, na Inglaterra, na França, na Alemanha, e na Espanha. ${ }^{322}$

O Choque das raças será o primeiro livro nosso que vai transpor as nossas fronteiras e que apresenta uma feição mundial. Sairá em cinco línguas simultaneamente, á A MANHÃ cabendo à primazia de dá-lo a público de primeira mão ${ }^{323}$.

O romance de Monteiro Lobato, escrito para um editor americano que assegura ao autor uma daquelas tiragens astronômicas que nos embasbacam, vem agitar os mais sérios problemas da espécie humana. [...] Obra de pensador sob capa da ficção, e

\footnotetext{
${ }^{319}$ Idem.

${ }^{320}$ Em 1927 é nomeado, por Washington Luís, adido comercial nos Estados Unidos, onde permanece até 1931.

${ }^{321}$ LOBATO, M. A Barca de Gleyre... (t. 2), p. 293-294). Carta de 08.07.1926.

322 O Choque das Raças: 'A Manhã' adquire os direitos de publicação do primeiro romance de Monteiro Lobato. A Manhã: Rio de Janeiro, 1 de setembro 1926, ano II, n. 211. p. 2.

${ }^{323}$ O Choque das Raças: Romance americano de Monteiro Lobato. A Manhã: Rio de Janeiro, 2 de setembro 1926, ano II, n. 212. p. 1.
} 
capaz de influenciar seriamente os espíritos de elite - os que conduzem o rebanho imenso, é de crer que a estreia de Monteiro Lobato cause no Brasil a mesma impressão que o Publisher ianque prevê nos Estados Unidos. ${ }^{324}$

O seu Publisher de Nova York, conhecedor da obra apenas por um resumo, escreve ao autor com entusiasmo muito compreensível, acenando com a possibilidade de uma tiragem de proporções astronômicas, caso o livro não se veja com a circulação proibida no território da grande república. ${ }^{325}$

Como se vê, $A$ Manhã proclamava que $O$ Choque não era um romance qualquer. Era uma obra ambientada nas terras do Tio Sam, escrita para um "editor ianque", e com uma proposta de publicação estrangeira. Tudo isso era motivo de saudação para Lobato e para os editores do periódico, e, mais do que isso, era um artifício publicitário do qual A Manhã se utilizou para chamar a atenção dos seus leitores. Pelo que nos conta as elogiosas propagandas diárias n'A Manhã e as cartas de Lobato ao seu amigo Godofredo Rangel, o romance seria publicado no Brasil, nos Estados Unidos e depois na Inglaterra. A margem de tiragem do livro seria "astronômica", uma média de 20.000, segundo o autor. ${ }^{326}$

Um romance americano, isto é, editável nos Estados Unidos. [...] Já tenho um bom tradutor, o Stuart ${ }^{327}$, e em New York um agente que se entusiasmou com o plano e tem boa percentagem no negócio. Imagine se me sai um best seller! Um milhão de exemplares... 328

De acordo com Carmen L. Azevedo, Marcia Camargos e Vladimir Sacchetta, a tiragem chegou à casa dos dezesseis mil exemplares, contudo, temos ciência de que os desejos lobatianos não se concretizaram. Somente em 1945 o livro foi reeditado, o que demonstra a pouca saída se comparado aos livros anteriores ${ }^{329}$. Assim, em maio de 1927, Lobato é nomeado Adido Comercial ${ }^{330}$ do governo brasileiro em Nova York, pelo então Presidente da

\footnotetext{
${ }^{324}$ O Choque das Raças: Romance americano de Monteiro Lobato. A Manhã: Rio de Janeiro, 3 de setembro 1926, ano II, n. 213. p. 1.

${ }^{325}$ O Choque das Raças: Romance americano por Monteiro Lobato, adquirido pela 'A Manhã'. A Manhã: Rio de Janeiro, 5 de setembro 1926, ano II, n. 215. p. 2.

326 "O meu Reino Louro ou $O$ Choque das Raças ou $O$ Presidente Negro (ainda não o batizei definitivamente) vai sair com 20.000 no mínimo. E soltamos a avalanche de papel sobre o publico como se fosse uma droga de farmácia, um Biotônico.” LOBATO, M. A Barca de Gleyre... (t. 2), p. 298. Carta de 07.02.1927.

${ }^{327}$ Em 1926, Lobato escreveu para o O Jornal uma série de artigos sobre Henry Ford que mais tarde foi compilada e editada em inglês por Aubrey Stuart (Cf.: AZEVEDO, Carmen L., et al. op. cit., p. 216). Não sabemos como eles se conheceram, mas, certamente, podemos imaginar que as intensões de Lobato era expandir o acesso de suas obras para, mais tarde, também expandir seu mercado editorial. Era uma chance de superar uma crise financeira pessoal e conquistar os Estados Unidos, tão admirado e bem quisto pelo autor.

${ }^{328}$ LOBATO, M. A Barca de Gleyre... (t. 2), p. 293-294. Carta de 08.07.1926.

${ }^{329}$ Em entrevista, Monteiro Lobato conta que na primeira edição de Urupês, em 1918, cerca de mil exemplares foram impressos e rapidamente esgotados, tanto que em 1919 já estava na quinta edição. Cf.: LOBATO, M. Prefácios e Entrevistas... p. 191 e LOBATO, M. A Barca de Gleyre... (t. 2), p. 206.

330 "A 27 de abril sigo de mudança para os Estados Unidos, para onde fui nomeado Adido Comercial. Verei se lanço lá a edição inglesa do Choque das Raças e estudarei a hipotese do transplante da nossa segunda empresa editora. Se for possivel chamar-se-á Tupy Publishing Co. E há de crescer mais que a Ford, fazendo-nos a todos milionarios - editores e editados. O Brasil é uma coisa perrengue demais para os planos que tenho na cabeça.
} 
República, Washington Luís. Essa ocasião the parecia mais do que propicia para publicar $O$ Choque, era, aliás, uma oportunidade única para viabilizar a construção de uma nova editora, a Tupy Publishing Company. "Talvez ingênuo, talvez megalômano, as duas coisas talvez. Os projetos de Lobato em pouco tempo revelam-se inviáveis. Os editores lhe fecham as portas, a editora não vinga" ${ }^{331}$.

Meu romance não encontra editor. Falhou a Tupy Company. Acham-no ofensivo á dignidade americana, visto admitir que depois de tantos séculos de progresso moral possa este povo, coletivamente, combater a sangue frio o belo crime que sugeri. Errei vindo cá tão verde. Devia ter vindo no tempo em que eles linchavam os negros. $^{332}$

Nessa correspondência, Lobato esbraveja o que há de mais obscuro em seus pensamentos em relação aos negros, pois não admitira que suas ideias fossem refutadas daquela maneira. Em missiva a Gastão Cruls ${ }^{333}$, Lobato revela que seu romance, um "ovo de escândalo", fora recusado por cinco "editores conservadores e amigos de obras bem comportadas", mas que um editor judeu se entusiasmara com a obra, pedia apenas que ele refizesse algumas partes e colocasse "mais matérias de exasperação".

O meu judeu acha que com isto até uma proibição policial obteremos - o que vale um milhão de dólares. Um livro proibido aqui sai na Inglaterra e na boothegued [sic] com o whisky e outras implicâncias dos puritanos. ${ }^{334}$

Seu romance havia sido impedido de ser publicado porque os editores norteamericanos acharam-no "ofensivo à dignidade americana" devido ao tenebroso passado desse país com os linchamentos de pessoas de cor em praça pública. No entanto, um judeu havia se interessado pelo $O$ Choque. Não sabemos ao certo quem foi esse editor judeu, nem mesmo se essa declaração é verossímil, dado que o romance jamais foi publicado no estrangeiro, e, tampouco, há outras menções ou correspondências sobre o assunto. Indignado, Lobato revelava como a realidade havia superado negativamente às suas expectativas. Infelizmente, os linchamentos, bradados por Lobato, foram constantes nos Estados Unidos durante o século XIX e início do XX. De acordo com Gibson,

In the last decades of the nineteenth century, the lynching of Black people in the Southern and border states became an institutionalized method used by whites to

[...] America, a terra de Henry Ford, o Jesus Cristo da Indusria!” (LOBATO, M. A Barca de Gleyre... (t. 2), p. 300. Carta de 23.03.1927).

${ }^{331}$ LAMARÃO, Sérgio. Os Estados Unidos de Monteiro Lobato e as respostas ao "atraso" brasileiro. Lusotopie. 2002/1: 51-68. p. 63. Disponível em <http://www.lusotopie.sciencespobordeaux.fr/lamarao.pdf $>$. Acesso em fevereiro de 2016.

${ }^{332}$ LOBATO, M. A Barca de Gleyre... (t. 2), p. 304. Carta de 05.09.1927.

${ }^{333}$ LOBATO, M. Cartas escolhidas...(v. 1). p. 218.

${ }^{334}$ Idem. 
terrorize Blacks and maintain white supremacy. In the South, during the period 1880 to 1940 , there was deep-seated and all-pervading hatred and fear of the Negro which led white mobs to turn to lynch law as a means of social control. Lynchings open public murders of individuals suspected of crime conceived and carried out more or less spontaneously by a mob seem to have been an American invention. In LynchLaw, the first scholarly investigation of lynching, written in 1905, author James E. Cutler stated that lynching is a criminal practice which is peculiar to the United States. $^{335}$

Considerado como a "mancha da civilização norte-americana" 336 , os linchamentos em praça pública de homens e mulheres negros constituem um passado macabro que assombrou o país por um longo período. No dia 25 de outubro de 1925, o Correio da Manhã lançou um artigo denunciando a então permanência dos linchamentos nos Estados Unidos, à despeito da criação de leis que o proibiam. Em A barbárie dos linchamentos nos Estados Unidos ${ }^{337}$, apresenta uma denúncia feita pela Associação Nacional Protetora da Raça Negra. De acordo com o texto, tudo levava a crer que

mesmo obtida legislação especial contra os linchamentos, em certos Estados norteamericanos, as autoridades subalternas, identificadas com o preconceito popular dos brancos, não defenderam eficazmente, seriamente, os da raça negra contra as execuções arbitrarias, deliberadas pela turba enfurecida. ${ }^{338}$

A pátria se apresentava aos homens de cor como uma "terrível madrasta e não [como] mãe carinhosa"339. Os linchamentos estampados orgulhosamente em cartões postais demonstravam como o desejo branco se sobrepujava ao negro. Para sensibilizar os leitores e ilustrar tamanha crueldade, o texto traz um relato do jornal Memphis Press $^{340}$ de um linchamento em praça pública:

Polegada a polegada, o negro foi assado até morrer. De minutos a minutos, ajuntavam-se novas folhas ao fúnebre montão, para que as chamas ultrapassassem a altura do negro. Quando elas lhe lambiam o ventre, um homem se destacou do meio do grupo e derramou benzina no corpo em contorções. Mesmo depois de se lhe ter a carne destacado das pernas e de lhe terem as chamas atingido o rosto, o negro estava consciente; mas não se lhe ouvia um só gemido. Uma ou duas vezes ele tentou agarrar as cinzas quentes e chegá-las á boca, para apressar a morte. Mas, de cada vez, alguém afastava as cinzas para que ele não as alcançasse. Depois, lançaram-lhe

\footnotetext{
335 GIBSON, Robert A. The negro holocaust: lynching and race Riots in the United States, 1880-1950. Disponível em < http://www.yale.edu/ynhti/curriculum/units/1979/2/79.02.04.x.html $>$. Acesso em fevereiro de 2016. p. 2

${ }^{336}$ MORAES, Evaristo de. A barbárie dos linchamentos nos Estados Unidos. Correio da Manhã: Rio de Janeiro, 25 de outubro de 1925, ano XXV, n. 9.432, p. 4. Disponível em <http://memoria.bn.br/DocReader/docreader.aspx?bib=089842_03\&PagFis=22850 > Acesso em junho de 2015. ${ }^{337}$ Idem.

${ }^{338}$ Idem

${ }^{339}$ Idem.

${ }^{340}$ Linchamento datado de 27 de janeiro de 1921.
} 
benzina no peito e na cabeça. Em poucos minutos estava reduzido a cinzas. A multidão dispersou. ${ }^{341}$

A maioria dos linchamentos se dava por enforcamento ou execução a tiros, e, da mesma forma, outros tantos eram de natureza horrenda: queima na fogueira, mutilações, castração e outros métodos brutais de tortura física. Essa prática, segundo Gibson, "foi uma combinação cruel do racismo e sadismo, que foi utilizado principalmente para sustentar o sistema de castas do Sul"342. As notícias dos linchamentos eram de conhecimento da população brasileira. Diversos periódicos comentavam a seu respeito e as notícias se disseminavam pelos portos e estradas do país ${ }^{343}$. Quando vemos Lobato proclamar a favor dos linchamentos para conquista própria, pensamos não somente na imagem generalizante que faz dos Estados Unidos, mas, também e, sobretudo, sobre o argumento negativo que constrói no romance de que os negros não eram confiáveis. Traiçoeiros por natureza, os negros surgem em $O$ Choque como representantes de um mal irremediável. Embora todo esse contexto, o romance de Lobato não foi aceito pelo país dos linchamentos, pois ia de encontro com o "novo" espírito norte-americano de esconder algumas manchas do passado.

Além deste romance, algumas correspondências apontam e corroboram seu posicionamento excludente, classista e preconceituoso. Suas confissões sobre o Brasil e os Estados Unidos revelam ainda mais o Monteiro Lobato racista e intolerante.

País de mestiços, onde branco não tem força para organizar uma Kux-Klan [sic], é
país perdido para altos destinos. (...) Um dia se fará justiça ao Ku-Klux-Klan:
tivéssemos aí uma defesa desta ordem, que mantém o negro em seu lugar, e
estaríamos hoje livres da imprensa carioca - mulatinho fazendo jogo do galego e
sempre demolidor porque a mestiçagem do negro destrói a capacidade
construtiva.

A obsessão por este país extrapolava as questões profiláticas eugênicas, e convergia para as mais diversas e cruéis ideologias contra o movimento negro. Nenhuma outro de suas obras foi tão clara nesse sentido como $O$ Choque das Raças. Embora empreendesse campanhas patrióticas em prol de uma nação autônoma e evoluída, Lobato demonstrava um total desapego e uma certa repulsa pelo povo brasileiro e pelas terras tropicais. O seu nacionalismo caminhava junto com o seu desprezo pelo povo brasileiro.

\footnotetext{
${ }^{341}$ Idem.

${ }^{342}$ Tradução livre. GIBSON, Robert A. op. cit., p. 3.

343 SLENES, Robert W. "O Horror, O Horror". O contexto da formação de identidades mestiças no Rio de Janeiro dos anos 1920. In: GOMES, Tiago de Melo. Um espelho no palco: identidades sociais e massificação da cultura no teatro de revista dos anos 1920. Campinas, SP: Editora da Unicamp, 2004. p. 18

${ }^{344}$ Missiva enviada a Arthur Neiva em 10 de abril de 1928. Cf.: Monteiro Lobato. BRAVO! Revista. Maio de 2011, ano 13, n. 165, p. 25.
} 
Que vontade de mudar de terra - ir viver num país vivo, como o dos americanos! Isto não passa dum imenso tartarugal. Tudo se arrasta."345

Não ficarei muito tempo nesta terra. O calor!... Já te disse que não tenho o trópico no sangue. Detesto os verdes eternos, o calor quase eterno, a tal primavera eterna que não passa da mais eterna e desesperante monotonia. Verde, verde, o ano inteiro! ${ }^{346}$

Rangel: eu sou um peixe que esteve fora d'água desde 1882, quando nasci, e só agora caiu nela. Isto aqui [Nova York] é o mar do peixe Lobato. Tudo como quero, como sempre sonhei. ${ }^{347}$

Sinto-me encantado com a América. O país com que sonhava. Eficiência! Futuro! Ninguém andando de costas! [...] Passarinho aqui é gente, Rangel. Todos os bichos aqui são gentes - cães, gatos, esquilos... E há hospitais para os bichinhos como não os há aí para os Jecas. ${ }^{348}$

Nas terras norte-americanas Lobato havia encontrado o seu novo lar. O seu único arrependimento era "ter acordado tão tarde, ter [ido] tão velho para este maravilhoso país"349 . Pensava que era uma "estupidez infinita ter estragado uma vida inteira" $" 350$ no Brasil, porque, embora tenha tido o seu romance negado, ainda estava convencido que os estadunidenses eram "o único povo inteligente que h[avia] no mundo" 351 . Apesar de seu deslumbramento inicial, Lobato entendia que a história deste país poderia servir como um parâmetro de evolução social a ser seguido pelo Brasil. Nessa empreitada, passa a estudar os modos de produção industrial dos Estados Unidos, principalmente, o modelo fordista. Acreditava que o desenvolvimento da indústria do combustível e do ferro era o caminho a ser seguido rumo à emancipação econômica brasileira.

As contradições presentes nos discursos de Lobato demonstram que ele era, como qualquer outro indivíduo, um sujeito histórico, e, portanto, suscetível aos mais variados sentimentos e paixões. Todavia, esse fato não inocenta Lobato de suas atitudes racistas e preconceituosas. Percebe-se que até agora sua trajetória foi sempre rumo à evolução nacional do Brasil e assim o seria até o fim. Nota-se que sua admiração pelos Estados Unidos oi alimentada ao passar dos anos, porém, tem o seu ápice em 1927, quando ele se muda para $1 a^{352}$. Do fascínio com a industrialização (fordismo) até a idolatria da eugenia negativa, nos

\footnotetext{
${ }^{345}$ LOBATO, M. A Barca de Gleyre... (t. 2), p. 243. Carta de 25.01.1922.

${ }^{346}$ LOBATO, M. A Barca de Gleyre... (t. 2), p. 292. Carta de 07.05.1926.

${ }^{347}$ LOBATO, M. A Barca de Gleyre... (t. 2), p. 302. Carta de 17.08.1927.

${ }^{348}$ Idem.

${ }^{349}$ LOBATO, M. Cartas escolhidas..., p. 214. Carta de 26.10.1927.

${ }^{350}$ Idem.

${ }^{351}$ LOBATO, M. Cartas escolhidas..., p. 219. Carta de 10.12.1927.

${ }^{352}$ Em 1909, Lobato mandava artigos traduzidos do Weekly Times para A Tribuna e O Estado de S. Paulo. Essa pode ser uma das formas pelas quais o autor tinha acesso aos noticiários dos EUA e por isso estava por dentro dos fatos desse país. LOBATO, M. A Barca de Gleyre... (t. 1), p. 250. Carta de 01.07.1909.
} 
deparamos com um Lobato pessimista e extremista, o qual não hesitava em erguer a bandeira da exclusão e da segregação.

Expressando sua maravilhamento pelas terras ianques, Monteiro Lobato não titubeou em reverenciar, elogiar e engrandecer os Estados Unidos em $O$ Choque. Sua tarefa era convencer Ayrton, e, consequentemente, todos os seus leitores, de que esse país seria o verdadeiro modelo de sociedade eugênica. A adoção de políticas de "restauração" social mostrava ao mundo a melhor solução para se perpetuar uma boa linhagem, tendo em vista a necessidade de reparação do infeliz cruzamento entre as raças branca e negra. A eugenia e o "princípio da Eficiência" foram suficientes para resolver os problemas morais e materiais dos Estados Unidos. Personificação da eugenia, Miss Jane relata como os norte-americanos conseguiram se livrar do caroço no sapato, em 2228, quando a situação do país chegou em um momento crítico e inédito em sua história. Com esse objetivo, retornemos à narrativa para compreendermos a realidade política e social deste país no futuro.

\section{Associação Negra, Partido Masculino e Partido Feminino: os três partidos norte-americanos de 2.228}

Com a morte de seu pai, Miss Jane toma o posto de professora e passa a educar o seu mais novo pupilo. Cada diálogo é uma oportunidade para apresentar os mecanismos e funções do Porviroscópio e convencer Ayrton dos benefícios da eugenia. Ressaltava a todo o momento a visão determinista, segundo a qual o futuro já estaria pré-definido e o destino fadado a se concretizar. Com o passar dos dias e dos capítulos, Miss Jane revela os conceitos e reforça as teorias bases da doutrina eugênica, analisa quais foram as suas implicações e efeitos nos Estados Unidos do presente e do futuro. Como uma excelente instrutora, gradualmente avança nos relatos e conteúdos, busca saber antes todas as convicções de Ayrton para, assim, testar seus conhecimentos sobre o assunto. Quando, no capítulo X, Ayrton comenta: “- Povo sem ideais, o mais materialão da terra. A gente do the biggest..."353, Jane não vê outra saída a não ser explicar como ele acabara de cometer um grande engano a respeito dos norte-americanos.

- Essa ideia não pode ser sua, senhor Ayrton. Soa-me a frase feita, das que recebem no ar sem exame. A um povo que rompe com o álcool acho o senhor sem ideias?

\footnotetext{
${ }^{353}$ LOBATO, M. O Choque das Raças. A Manhã: Rio de Janeiro, 11 de setembro 1926, ano II, n. 220 . p. 4.
} 
Poderá haver maior idealismo que o sacrifício de formidáveis interesses materiais do presente, em vista de benefícios que só as gerações futuras poderão recolher? Se o senhor Ayrton observar um pouco a psique americana verá, ao contrário, que é o único povo idealista que floresce hoje no mundo. Único, vê? Apenas se dá o seguinte: o idealismo dos americanos não é o latino que nós importamos com o sangue. Possuem-no de forma especial, próprio e de implantação difícil em povos não dotados do mesmo caráter racial. ${ }^{354}$

Devemos dar uma especial atenção à esse diálogo, pois Miss Jane trata Ayrton da mesma forma que Lobato trata o leitor: um leigo no assunto, possuindo apenas o senso comum sobre os Estados Unidos e suas políticas públicas e sociais. Ao repetir uma frase feita de seus patrões, Ayrton demonstrava total desconhecimento do país de que Miss Jane tanto comentara. De fato, até então ele nunca havia demonstrado curiosidade sobre esse país, uma vez que sua realidade estava tão distante dele. Atenta a esse fato, Jane descreve a "verdadeira" situação daquele país, exemplo de idealismo e "caráter racial”.

Reparem que, para exaltar os americanos, Miss Jane deprecia o Brasil. Ora, aqui, o idealismo era frouxo e frágil, lá, era especial, de difícil penetração naqueles que não possuíam o mesmo "caráter racial superior". Em 1920, os EUA haviam implementado a Lei Seca com o intuito de salvar o país do alcoolismo, e estabelecia a proibição de produção e comercialização de bebidas alcoólicas. Por aqui, o álcool continuava a destruir a vida de homens e mulheres dos campos e das cidades, aumentando o número de dependentes do álcool. De acordo com Miss Jane, a implementação de leis como essa tinham por traz um idealismo pragmático, com objetivos certeiros e factuais. Assim, esse país conseguia vencer o bom e velho "bom senso",355 e restaurar parte da sociedade.

Essa comparação (sempre negativa), Brasil versus Estados Unidos, está presente em toda a narrativa do romance. A intenção do autor era fazer com que os leitores refletissem sobre a situação nacional do país, tendo como parâmetro de análise a exitosa história americana e suas conquistas políticas e sociais no presente e, principalmente, no futuro. Os EUA são, de acordo com o autor, o maior exemplo de como as ideias eugênicas foram podiam ser bem sucedidas a curto e longo prazo. Precisamente a partir do capítulo X, Céu e Purgatório, Lobato passa a expor as teorias eugênicas nas páginas de $O$ Choque, a partir desse momento defende com unhas e dentes os motivos pelos quais a raça branca deveria ser considerada superior entre os seres humanos.

\footnotetext{
${ }^{354}$ Idem.

${ }^{355}$ LOBATO, M. O Choque das Raças. A Manhã: Rio de Janeiro, 12 de setembro 1926, ano II, n. 221 . p. 5.
} 
A eugenia resumia-se, tanto no romance como nas teorias dos cientistas, num ato de solidariedade e de prosperidade para as gerações presente e vindoura. Era um movimento em prol do bem em comum da sociedade, onde não havia lugar para o egoísmo e o esmorecimento. Segundo Renato Kehl,

\begin{abstract}
A Eugenia é uma ciência incompatível com o egoísmo. Ela não germina e dá frutos para o gozo completo e imediato do semeador. É uma árvore que quase só frutifica e beneficia a posteridade. Não sejamos, pois, doutrinários do "Ego", do desejo exclusivista de só cuidar de si, daqueles que, dispensando egoisticamente os potenciais da vida, costumam legar aos filhos, em vez de patrimônio de saúde, que é a mais rica das heranças, dívidas muitas vezes pagas com a decadência e o sacrifício dos descendentes. ${ }^{356}$
\end{abstract}

Plantar e semear no presente para as próximas gerações colherem os frutos no futuro, esse era o lema dos eugenistas. Miss Jane compactuava deste mesmo ideal, tanto que durante a narrativa dá exemplos de intelectuais e como suas ações haviam interferido na sociedade como um todo. Henry Ford é citado por ela como um grande exemplo de homem visionário que pensava o futuro. Ele era como um "martelo trepidante"357 que desobstruía do pensamento ideias falsas e ressoava com o princípio da eficiência. Os Estados Unidos se destacavam, ainda de acordo com a moça, pelo seu passado admirável, pelos seus colonizadores ingleses ${ }^{358}$ e pelos homens que trabalhavam em prol do futuro da nação, como Ford. Ayrton Lobo, depois das justificativas e argumentos de Miss Jane, é convencido da superioridade deste país: “ - Realmente!... [...] Vejo agora que fazemos uma ideia falsa desse povo",359.

Então persuadido da superioridade do povo estadunidense e da necessidade da implementação da eugenia negativa, Ayrton Lobo começa a ter conhecimento da situação política e social dos EUA de 2228. Somente a partir do nono dia de publicação, no capítulo XIII, Política de 2228, que o leitor consegue saciar sua curiosidade sobre o tão falado e consagrado choque das raças. A disputa presidencial de 2228 é revelada por Miss Jane. Diferentemente do presente, onde somente havia os Partidos Republicano e Democrático, no futuro três partidos estavam na briga eleitoral. O Partido Masculino representava todos os

\footnotetext{
${ }^{356}$ KEHL, Renato. Eugenia e medicina social (problemas da vida). $2^{\text {a }}$ edição, Livraria Francisco de Assis: Rio de Janeiro. 1923. Arquivo AEL, Coleção Paschoal Lemme, obras raras. Primeira edição lançada em 1920. p. 177 ${ }^{357}$ LOBATO, M. O Choque das Raças. A Manhã: Rio de Janeiro, 12 de setembro 1926, ano II, n. 221. p. 5. 358 "Os primeiros colonos, quais foram eles? A gente do May-flower, quem era ela? Homens de tal tempera, de caráter tão firme, que entre abjurar das convicções religiosas e emigrar para o deserto, para a terra vazia e selvagem onde tudo era inospitalidade e dureza, não vacilaram um segundo. Emigrar ainda hoje vale por alto expoente de audácia, de elevação do tônus vital. Deixar sua terra, seu lar, seus amigos, sua língua, cortas as raízes todas que desde a infância nos prendem ao solo pátrio, haverá maior heroísmo? Quem o faz é um forte, e por esse simples fato já revela um belo índice eugênico." (Idem.)

${ }^{359}$ Idem.
} 
homens brancos do país, tendo Kerlog - presidente em exercício e candidato à reeleição como líder e figura ativa no processo de embate entre as raças branca e negra. Do outro lado, encontramos Miss Astor, representante do Partido Feminino, que lutava pelas causas feministas. Por fim, há Jim Roy, “o negro de gênio",360 , o representante legítimo da raça negra e líder da Associação Negra.

Os rumos da eleição daquele ano encontravam-se, então, nas mãos de Jim Roy, pois, segundo Miss Jane, os antigos partidos

\begin{abstract}
Democrático e Republicano, haviam-se coligado num forte bloco sob a denominação do Partido Masculino. Mesmo assim não se viam seguros da vitória, porque o partido contrário, o Feminino, dispunha de maior número de vozes. Estava, pois, em jogo o prestígio político do homem, batido pelo da mulher em todos os campos de atividade e a defender agora o seu último reduto - a presidência da República. [...] Miss Astor insistia de novo na sua candidatura, e agora com mais probabilidades de vencer, visto como era mito possível que o grande líder [sic] negro se deixasse levar pela sedução dos seus argumentos. Do outro lado o senhor Kerlog, presidente em exercício e candidato à reeleição, só via possibilidade de êxito se obtivesse o concurso de Jim, como sucedera no pleito anterior. ${ }^{361}$
\end{abstract}

Desta forma, o posicionamento do líder negro era imprescindível nos resultados das eleições daquele ano. Tanto Kerlog como Miss Astor lutavam pelo apoio eleitoral de Jim Roy, e cada um, a sua maneira, buscava uma forma de persuadi-lo. A líder feminina acreditava em seus poderes de sedução para fisgar o homem negro. Kerlog, por sua vez, confiava que o orgulho masculino faria Jim apoiá-lo como antigamente, porque unir-se ao Partido Feminino, segundo o líder branco, era o mesmo que ferir o "prestígio político do homem". O embate histórico entre homens e mulheres da raça branca aparece no romance como um fator decisivo para o desenrolar do choque das raças. Por isso, aqui vale uma breve pausa, pois de instigante reflexão é a figura da mulher encontrada nessa obra literária.

$\mathrm{O}$ "corte anatômico" feito nesta digressão refere-se à representação da mulher em $O$ Choque. Vamos começar com Miss Jane, filha do Professor Benson, pois ela é a primeira figura feminina que encontramos na narrativa. Cabelos louros, olhos azuis e elegante, essas são as primeiras características que chamam a atenção do personagem principal, Aryton Lobo, e o fazem suspirar já em seu primeiro encontro ${ }^{362}$. Ao longo da narrativa, Lobato nos

\footnotetext{
${ }^{360}$ LOBATO, M. O choque das raças. A Manhã: Rio de Janeiro, 14 de setembro 1926, ano II, n. 222. p. 5.

${ }^{361}$ LOBATO, M. O choque das raças. A Manhã: Rio de Janeiro, 15 de setembro 1926, ano II, n. 223. p. 5.

362 "Mas cabelos louros como aqueles, olhos azuis como aqueles, esbelteza e elegância de porte, como as de Miss Jane, eram ingredientes fortes demais para que não produzissem a ruptura do meu equilíbrio nervoso [...] criatura finamente educada e generosa." Cf.: LOBATO, M. O choque das raças. A Manhã: Rio de Janeiro, 5 de setembro 1926, ano II, n. 215. p. 5.
} 
apresenta, de forma fragmentada, as características dessa personagem, deixando-nos muitas vezes inquietos e receosos quanto a algumas descrições.

Companheira de seu pai até na paixão pelos estudos e pesquisas, Miss Jane era diferente da maioria das mulheres. Sua formação científica e "frieza de sábio"363 eram resultados de seu "convívio com um homem superior" que a afastou de "todas as preocupações do coquetismo, próprias da mulher comum"364. Nela, de feminino só havia o aspecto físico, segundo Ayrton. Sua figura, sua fala e sua postura eram próprias de homens sábios, podendo ser confundidas com a postura dos eugenistas da década de 1920. Miss Jane "é a expressão mais bem acabada de uma eugenista que acredita firmemente na ciência em questão" "365 . É pela voz dessa doce moça que Lobato traduz as doutrinas eugênicas vigentes no contexto histórico de 1926. Ela é a sua porta-voz no processo de iniciação de Ayrton - e dos leitores - às reflexões e doutrinas eugênicas.

A figura emblemática de Miss Jane faz Ayrton Lobo questionar-se ao longo de toda a narrativa sobre a sua postura de sábia e mulher., que, de acordo com ele, não eram compatíveis.

- Sábia também ela, mas, ai! bem pouco feminina... O Amor que ardia em meu peito não a contagiava. Talvez nem sequer o percebesse. Ou percebera desde o início ou dissimulava?

A misteriosa Miss Jane resumia-se, para ele, numa dupla divindade, num "misto de Afrodite e Minerva" ${ }^{, 366}$, onde amor e razão se confrontavam a todo momento. O sentimento de estar sendo enganado pela impassibilidade e quietude de Miss Jane confundia a mente e os sentimentos deste homem. Diversas vezes o encontramos se questionando quanto ao afeto dela para com ele. Não era possível que ela não captava e nem, ao menos, compreendia os seus sentimentos. Estaria ela a dissimular e a enganá-lo? Afinal, ela era uma mulher e, por isso, deveria ser intuitiva e entender as intenções e emoções deste homem.

Interessante ressaltar que a figura da mulher simbolizada primeiramente na figura de Miss Jane traz em si algumas convicções pessoais de Monteiro Lobato. Em uma correspondência, ele declarou que na mulher reside o melhor e o pior da humanidade, "elas

\footnotetext{
363 "Minha filha, senhor Ayrton, possui mais frieza de sábio do que eu. Não perde tempo em formular hipóteses quando tem meios de verificar experimentalmente." Idem.

${ }^{364}$ LOBATO, M. O choque das raças. A Manhã: Rio de Janeiro, 7 de setembro 1926, ano II, n. 216. p. 5.

${ }^{365}$ HABIB, Paula A. B. B. op. cit., p. 95.

${ }^{366}$ LOBATO, M. O choque das raças. A Manhã: Rio de Janeiro, 5 de setembro 1926, ano II, n. 215. p. 5.
} 
levam até ao grau 100 qualidades ou vícios"367. Para o escritor paulista, não existia meio termo para elas, quando boas, o são em grau máximo, e quando ruins, são terríveis. Esse binômio, muitas vezes favorecia o caráter cambiante das mulheres, o que vem a corroborar e justificar o jargão lançado em $O$ Choque nas falas de Kerlog: "She was false as water",368. Essa célebre frase shakespeariana nos leva a pensar sobre o caráter "ondeante" e “dissimulador" associado por Lobato às mulheres de sua época.

Bela, racional, independente e inteligente, Miss Jane arrebatava o humilde coração de Ayrton. Certa vez, quando perguntou se ela já havia pensado em casamento, Jane fez uma pausa e refletiu dizendo ser aquela a primeira vez que tal palavra soava em sua casa. "Amor! Que é amor, senhor Ayrton? O seu vocabulário é tão novo para mim como deve ser para o seu

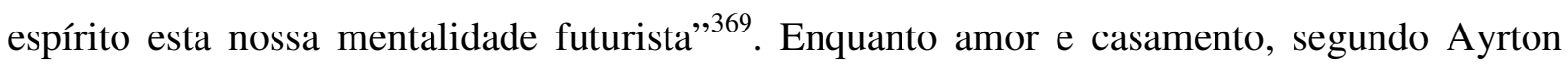
Lobo, constituíam uma obsessão para todas as mulheres de 1926, existia Miss Jane, uma mulher alheia a tudo isso. Ao fazer uma análise de si mesma, ela chegava a conclusão que "não só pensava em amor e casamento, mas a qual tais palavras ressoavam como vozes inéditas" ${ }^{370}$. Esses trechos parecem querer mostrar que razão e emoção não andavam juntas, e que, talvez por isso, Miss Jane era "fria como sábio".

Também é importante ressaltar as características físicas da filha de Benson: os belos olhos azuis e os luminosos cabelos louros. Acreditamos que Lobato exalta esses atributos com a intenção de demonstrar que, além de sábia, ela possuía sangue superior da melhor estirpe e não era mestiça ${ }^{371}$. Curioso observar que no texto da Revista do Brasil: Qual a mulher que sabe amar mais o homem? $?^{372}$, encontra-se uma análise "científica" que determina as características físicas como decisivas na constituição da personalidade das mulheres. Seu autor (desconhecido) afirma serem os sentimentos femininos resultados dos caracteres fenotípicos.

\footnotetext{
${ }^{367}$ LOBATO, M. A Barca de Gleyre... (t. 2) p. 235. Carta de 25.07.1921.

${ }^{368}$ LOBATO, M. O choque das raças. A Manhã: Rio de Janeiro, 21 de setembro 1926, ano II, n. 226. p. 4.

${ }^{369}$ LOBATO, M. O choque das raças. A Manhã: Rio de Janeiro, 9 de setembro 1926, ano II, n. 218. p. 5.

${ }^{370}$ Idem.

${ }^{371}$ Professor Benson era filho "de um mineralogista norte-americano" que veio ao Brasil para estudar algumas zonas auríferas. Gostou tanto do país que por aqui ficou, se casou com uma filha de fazendeiro de São Paulo e teve Benson como único filho. Enviado à Europa ainda jovem, Benson por lá "se dedicou a estudos científicos", se casou com uma jovem e teve Miss Jane. Sua mãe, segundo Miss Jane, "morreu muito moça, aos 29 anos". A partir de então, Benson decidiu retornar e se estabelecer no Brasil. Cf.: LOBATO, M. O choque das raças. $A$ Manhã: Rio de Janeiro, 21 de setembro 1926, ano II, n. 228. p. 4.

${ }^{372}$ Resenha do mês: Qual a mulher que sabe amar mais o homem? Revista do Brasil. São Paulo, Volume XVII. Maio - Agosto, 1921. Ano VI (n 65-68), p. 461-462.
} 
Os estados de alma, a hora simpática da mulher, com as suas alternativas violentas ou brandas, estão na razão direta da cor de sua tez, de seus cabelos, de seus olhos, na correção de suas linhas e contornos, na harmonia de seus gestos. A sentimentalidade feminina tem tanta diversidade na aparência como nos temperamentos, como tem demonstrado os estudos mais profundos das mulheres loiras e morenas, para saber qual delas sabe melhor amar e ser constante. ${ }^{373}$

O autor comenta que, de acordo com essas pesquisas, era possível delinear o perfil das mulheres loiras e morenas. A coloração da pele, dos olhos e dos cabelos, eram determinantes para a formação do temperamento feminino. "A loira é a mulher-sensação, a morena é a mulher-sentimento" 374 . Haveria, portanto, grande diferença na composição orgânica entre loiras e morenas, o que refletia diretamente na concepção da índole de cada uma. Essa diferença, segue o artigo, se dava em função da glândula pineal. Assim, por trás dos cabelos claros estavam a razão e o pragmatismo, a mulher loira ajudava mais e melhor o seu marido "na luta pela vida em que há completa ausência de sentimentalismo"375. A morena, resultado da miscigenação, amava mais o seu marido pelo fato de estar totalmente ligada às paixões e aos prazeres da carne. Levava-se em consideração que o clima temperado não exigia "lutar com denodo para viver" e que, por isso, a mulher morena conseguia ser mais sentimental. Talvez a postura indiferente de Miss Jane às paixões e sentimentos seja reflexo das leituras de Lobato na Revista do Brasil. Esse texto foi publicado em 1921, no volume XVII, cinco anos antes da publicação de $O$ Choque. É muito provável que ele tenha tido conhecimento deste e de outros artigos que chegavam a conclusões semelhantes.

Leitor atento e curioso que era, Monteio Lobato não deixaria essa discussão passar despercebida. Certamente outras literaturas informaram-no sobre a personalidade das mulheres, além, é claro, de suas próprias observações e convicções pessoais. Por isto, Miss Jane não é a única mulher da sua narrativa. $\mathrm{O}$ autor também criou as personagens Miss Astor e Miss Elvin, representantes do Partido Feminino em 2228. A partir delas podemos traçar outro perfil de mulher apresentado pelo autor. "Independentes", ambas são mulheres fortes e inteligentes, porém, cometem um erro crucial, divorciam-se do homem, seu "marido milenar". Se nos questionávamos sobre a personalidade fragmentada de Miss Jane, com Miss Astor e Miss Elvin não seria diferente. Há mais lacunas e peças soltas na construção dessas personagens. Elas aparecem pouco e suas características psicológicas são bem superficiais. Quando o autor fala de Miss Astor o que se sobressai, mais uma vez, são as suas belas características físicas:

\footnotetext{
${ }^{373}$ Idem.

${ }^{374}$ Idem.

${ }^{375}$ Idem.
} 
uma mulher habilíssima na qual há todos os dotes da inteligência, da cultura e da maquiavélica sagacidade feminina se juntava um elemento perturbador e novo no jogo politico presidencial: a sua rara beleza física. ${ }^{376}$

Seus atributos físicos desnorteavam a todos de 2228, Miss Astor hipnotizava a todos com sua beleza e inteligência. Miss Elvin, por outro lado, é apresentada por Lobato como a escritora de A simbiose desmascarada, e expressão máxima do movimento feminista de 1926, e é, portanto, uma mulher masculinizada. Perceba que a beleza física das mulheres constitui elemento fundamental na descrição de cada uma das personagens femininas. Miss Elvin, entretanto, por levantar a bandeira do feminismo é caricaturada como anti-feminina. Em consequência disso, nota-se uma crítica de Lobato ao manifesto feminista no início do século $\mathrm{XX}$.

Miss Elvin era a representante máxima do movimento feminista da época e havia encabeçado uma ação separatista entre homens e mulheres. Suas teorias ${ }^{377}$ recrudesciam e $^{2}$ assim solidificavam ainda mais as fronteiras que separavam os dois gêneros. Esse movimento não é visto com bons olhos por Miss Jane, a narradora dos "dramáticos" acontecimentos de 2228.

Quando no mundo surgiu o feminismo, toda a gente supôs que a solução do
problema da mulher estava em nivelá-la ao homem pela cultura e igualdade de
direitos. Erro cascudo, demonstrou Miss Elvin. A cultura como a criara o homem
não se adaptava ao cérebro da mulher, de funcionamento especialíssimo e sempre
influenciado por certas glândulas misteriosas. Falhou por isso o feminismo. De toda
a sua agitação só veio a resultar uma coisa: a feminista, a odiosa mulher-homem,
que pensava com ideias de homem, usava colarinhos de homem, conseguindo com
isso apenas...
-... não ser homem nem mulher [...].

A postura de Miss Jane contrária ao movimento feminista não só nos remete ao contexto político e social de 1926, mas, sobretudo, nos informa sobre o posicionamento de Lobato frente a este caloroso debate. As mulheres adeptas ao feminismo são, consequentemente, ridicularizadas como "odiosa mulher-homem" que não conseguia ser uma

\footnotetext{
${ }^{376}$ LOBATO, M. O choque das raças. A Manhã: Rio de Janeiro, 15 de setembro 1926, ano II, n. 223. p. 5.

377 "Miss Glória Elvin era a autora de uma obra arrojadíssima, A Simbiose desmascarada. Graças à vivacidade do estilo e ao fulgor dos argumentos, esse livro causara uma verdadeira revolução nos Estados Unidos. A ideia central de Miss Elvin cifrava-se em que a mulher não era a fêmea natural do homem, como a leoa o é do leão, a galinha do galo, a delfina do delfim. A fêmea natural do homem ele a repudiara em época recuadíssima - e tudo levava a crer na extinção desse pobre animal. Repudiara-a e tomara para si, como os antigos romanos fizeram às sabinas, a fêmea de um outro mamífero de vagas semelhantes anatômicas com o homo. Supunha Miss Elvin que seriam marinhos esses 'sabinos' pré-históricos e anfíbios, assim romanamente despojados das suas fêmeas. E, recriando a imaginação com um pouco de fantasia, chegou a descrever num segundo livro, de igual sucesso o massacre dos sabinos quando do seio das ondas acudiram às praias em defesa das raptadas metades. Vinha daí o caráter ondeante da mulher. 'She was false as water', já o dissera Shakespeare." Idem.

${ }^{378}$ LOBATO, M. O choque das raças. A Manhã: Rio de Janeiro, 19 de setembro 1926, ano II, n. 227. p. 4.
} 
coisa nem outra, apenas uma aberração. A busca pela igualdade de direitos é tida como incoerente dado que homens e mulheres eram, em sua essência, diferentes, e os mecanismos do cérebro feminino tinha um "funcionamento especialíssimo" influenciado por "glândulas misteriosas". Com essas análises, chegava-se a conclusão que o feminismo falhara porque era insensato.

Fica evidente a linha de raciocínio utilizada por lobato para construir suas personagens femininas quando nos deparamos com diversos textos e artigos da época que discutiam o debate feminista. O feminismo vinha ganhando vozes pelo mundo a fora e no Brasil começava-se a questionar a regulamentação do voto feminino. As diárias reportagens sobre o sufrágio feminino e sobre assuntos gerais pertinentes ao movimento feminista brasileiro nos periódicos Gazeta de Notícias, Correio da Manhã e A Manhã, certificam que o autor estava se posicionando frente a esse debate.

Esses jornais publicavam os mais diversos posicionamentos possíveis sobre o assunto. Encontramos várias entrevistas nas quais as mulheres se declaram contrárias ao sufrágio feminino por acreditarem que elas não estavam preparadas para tamanha responsabilidade, ou então, porque lhes faltavam um "espírito de agremiação"379. Bidú Sayão, uma das maiores cantoras de ópera do Brasil, acreditava que somente "devia ser concedido o voto às mulheres cultas" ou àquelas "que tivessem, pelo menos, um curso qualquer" 380 .

Bem localizada, ao centro da primeira página da edição d'A Manhã do dia 03 de julho de 1926, consta a reportagem, O Voto Feminino - fala-nos o deputado Azevedo Lima. Nela o político, grande partidário das causas femininas, diz lutar pelo sufrágio universal, mas reitera ao dizer que essa conquista, embora grande e difícil, não significava muito, tendo em vista a gama de fatores que ainda separavam e distinguiam os dois sexos. Interessante notar que o diário de Mário Rodrigues não era contra nem a favor do voto feminino, pois não se proclamava favorável a nenhuma causa, uma vez que publicava divergentes opiniões sobre o assunto.

\footnotetext{
${ }^{379}$ Perguntada pelo jornal A Manhã se era a favor do voto feminino, a poetisa Sra. Laurita Lacerda Dias responde: "Ainda não! O triunfo individual da mulher brasileira é um fato incontestável. A sua capacidade, de trabalho, a sua competência se vem revelando em todos os ramos de atividade [...]. Apesar de tudo isso ainda não se acha em condições de obter o direito do voto! Falta-lhes, ainda, o espírito de agremiação, de coordenação nos atos sociológicos". Cf.: O voto feminino no Brasil. A Manhã: Rio de Janeiro, 4 de julho 1926, ano II, n. 160, p. 2.

${ }^{380}$ Uma palestra com Bidú Sayão. A Manhã: Rio de Janeiro, 6 de julho 1926, ano II, n. 162, p. 2.
} 
Essas são algumas (entre muitas) visões encontradas em nossas fontes, que demonstram como os jornais da época davam destaque ao debate feminista, especialmente, no que diz respeito a luta pelo voto das mulheres. O que vem comprovar, mais uma vez, o íntimo diálogo entre a narrativa de $O$ Choque e o contexto social e político brasileiro. A crítica "ferina" e "ácida" que Monteiro Lobato faz às feministas ganha forma acabada no erro cometido pelas mulheres brancas ao se divorciarem do homem branco, seu legítimo parceiro. Essa atitude teve como consequência o fortalecimento do grande inimigo da raça branca, Jim Roy. Cabe mencionar que a questão de gênero se colocava apenas para os homens e mulheres brancos. No caso da população negra, Lobato parece entender não haver qualquer distinção.

Nesse sentido, a existência de um cenário político fragmentado contribui para a associação integral dos representantes da raça negra sob a bandeira de um único partido. Essa conquista fez com que Jim Roy ganhasse representatividade e espaço na sociedade de tal forma que o futuro dos Estados Unidos passou a depender de seu posicionamento político. Em lados opostos, os Partidos Masculino e Feminino brigavam pelo seu apoio. A coligação da Associação Negra iria definir o grande vencedor, pois, segundo as estatísticas: Kerlog contava com 51 milhões de vozes, Miss Astor com 51 e meio, e Jim Roy com 54 milhões. “A próxima eleição dependeria pois exclusivamente da atitude do grande negro"381.

Tanto Kerlog como Miss Astor prontificaram-se para obter o suporte de Jim Roy, e, certos de sua colaboração, cada partido anunciava a sua eminente vitória. O Partido Feminino confiava no apoio do partido negro por ver em Kerlog o principal opositor do homem negro, o "inimigo tradicional da sua raça" ${ }^{382}$. O líder branco, por outro lado, tinha esperanças de que Jim Roy jamais se inclinaria à facção do sexo oposto, posto que o que estava em jogo era "o prestígio político do homem"383 independente de sua raça. Nesse contexto, Jim Roy passa a pressionar o Partido Masculino. Queria o líder negro, em troca do seu apoio político, algumas concessões. Uma delas se referia diretamente à atenuação da Lei Owen. Promulgada pelo Ministério da Seleção Artificial, essa lei era resultado das ideias pregadas por Walter Owen em seu livro $O$ direito de procriar, no qual lançou os fundamentos do "Código da Raça". Este Código "promoveu a esterilização dos tarados, dos malformados mentais, de todos os

\footnotetext{
${ }^{381}$ LOBATO, M. O choque das raças. A Manhãa: Rio de Janeiro, 15 de setembro 1926, ano II, n. 223. p. 5. De acordo com o censo demográfico relativo à população afro-americana nos EUA, em 1920, existiam cerca de 10,5 milhões de negros nesse país, ou seja, 9,9\% da população. Cf.: Statistical Abstract of the United States: 2003, e We, The American Blacks, U.S. Census Bureau, 1993. Disponível em: $<$ http://www.infoplease.com/ipa/A0922246.html>, acesso em janeiro de 2016.

${ }_{382}^{38}$ LOBATO, M. O choque das raças. A Manhã: Rio de Janeiro, 15 de setembro 1926, ano II, n. 223. p. 5. ${ }^{383}$ Idem.
} 


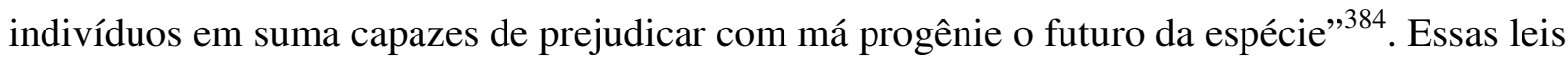
e restrições visavam à restauração do homem por meio do aperfeiçoamento da raça. No entanto, seus rigores tinham se agravado no ano anterior, e, como consequência, havia a perceptível diminuição dos índices de crescimento da população negra no país. O que contrariava a política protecionista racial do líder negro, "resumida em favorecer a expansão de seu povo",385.

Essa lei representava, nas palavras de Miss Jane, o ressurgimento da "sábia lei espartana".

\begin{abstract}
- Se o senhor Ayrton visse, como eu vi, o resultado dessa e de outras leis semelhantes, só se admiraria da estupidez do homem em retardar por tanto tempo a adoção de normas tão fecundas. Entre cortar no início o fio da vida a uma posta de carne sem sombra de consciência e deixar que dela saia o ser consciente que vai vegetar anos e anos na horrível categoria dos 'desgraçados', a crueldade está no segundo processo. A lei espartana reduziu praticamente a zero o número de desgraçados por defeito físico. Restavam os desgraçados por defeito mental. ${ }^{386}$
\end{abstract}

A teoria que dizia ser a lei espartana uma sábia legislação não era propriedade exclusiva de Monteiro Lobato. Os eugenistas também acreditavam que a civilização ideal seria aquela que vivesse de acordo com as antigas leis gregas. O culto ao corpo espartano e à inteligência ateniense pareciam-lhes pertinentes. Para Renato Kehl e seus prosélitos, e, mais tarde, para Hitler, o ideal de beleza física almejada era o grego ${ }^{387}$. No entanto, os eugenistas já haviam analisado suas falhas enquanto civilização, e não queriam cometer os mesmos erros.

\begin{abstract}
Mas, como faz notar judicioso comentador, a organização espartana pecava por dois erros fundamentais: o espartano era um guerreiro e não um trabalhador e, conquanto rude e honesto, um aristocrata. Com desprezo abandonava o trabalho aos escravos ou hilotas. Desse modo, fortificavam-se estes, enquanto eles próprios se enfraqueciam. Não compreendiam ainda o valor fortalecedor do trabalho para o cérebro e para o corpo... todos os seus esforços eram dirigidos para a força muscular, destreza corporal, coragem, honestidade e simplicidade de costumes, mas, nunca para a elevação da inteligência e dos sentimentos ${ }^{388}$.
\end{abstract}

A admiração para com os gregos tinha suas ressalvas. Era necessária uma adaptação. A eugenia acreditava que o erro dessa civilização estava associada à procrastinação do trabalho. Era indispensável a união das atividades braçais e mentais em prol da eficiência e evolução da sociedade. Trabalho era sinônimo de eficiência e evolução social. O modelo ideal

\footnotetext{
${ }^{384}$ Idem.

${ }^{385}$ Idem.

${ }^{386}$ LOBATO, M. O choque das raças. A Manhã: Rio de Janeiro, 14 de setembro 1926, ano II, n. 222. p. 5.

${ }^{387}$ HABIB, Paula A. B. B. op. cit., p. 145.

${ }^{388}$ KEHL, Renato. O homem puro-sangue: a possibilidade da sua criação. Gazeta de Notícias: Rio de Janeiro, 13 de abril de 1923, ano XLVIII, n. 87, p. 1. Disponível em: <http://memoria.bn.br/DocReader/docreader.aspx?bib=103730_05\&PagFis=8463> Acesso em janeiro 2016.
} 
seria aquele que combinasse a estética corporal espartana com o culto ao intelecto ateniense. Trabalhadas e estimuladas separadamente, tanto as leis espartanas como as atenienses, não teriam resultados profícuos e acabariam, em longo prazo, por sucumbir como outrora.

Há uma linha tênue entre ficção e realidade. O debate em torno das leis e restrições impostas nos Estados Unidos de 2228 era uma realidade almejada pelos eugenistas brasileiros de 1926. Renato Kehl publicou na Gazeta de Notícias um artigo sobre o assunto no qual examina que

Licurgo, legislador de Esparta, foi o campeão da obra selecionadora, a avaliar pelo seu capricho obstinado e selvagem, por que determinava fossem lançadas ao Eurotas as pobres e infelizes crianças cuja desdita lhe ditara a sina de virem ao mundo rechiticas [sic] e degeneradas. Esse tirano, que viveu no $9^{\circ}$ século antes da era cristã, não concebia a hipótese de entes cacogênicos perpetuarem sua monstruosidade, fealdade ou doença. O Eurotas era para ele o remédio radical contra a degeneração, o tumulo da anormalidade. ${ }^{389}$

O "sapiente e precavido",390 Licurgo em tempos remotos, sem auxílio da ciência moderna, seria uma espécie de eugenista avant la lettre, de acordo com Kehl. O "critério selecionista" praticado por seu povo poderia servir de exemplo para a solução dos problemas sociais brasileiros. Reformulações se faziam necessárias, mas o princípio de beleza e de saúde espartana deveria ser mantido em prol do bem comum. Compartilhando desses ideais, Monteiro Lobato utiliza-se de Miss Jane para dar voz às suas palavras e vida às teorias eugênicas.

Dado o exposto, a professora continua a contar a Ayrton os Estados Unidos de 2228 haviam se progredido após colocarem em prática os preceitos eugênicos. Além do controle e consequente eliminação dos disgênicos, a sábia ciência, com o passar do tempo, trouxe consigo avanços imensuráveis para nação norte-americana. Não mais existiam automóveis, pois o rádio transporte tomara seu lugar; as antigas ruas transformaram-se em largar calçadas onde as pessoas passeavam livremente; existia a cidade do amor, Erópolis, para onde os casais em lua de mel iam a fim de desfrutar dos prazeres e para conceber nobres herdeiros. Crimes e delinquências eram coisas do passado. Tudo isso graças à Lei Owen que havia feito desaparecer

[...] os surdos-mudos, os aleijados, os loucos, os morféticos, os histéricos, os criminosos natos, os fanáticos, os gramáticos, os místicos, os retóricos, os vigaristas,

\footnotetext{
${ }^{389}$ Idem.

${ }^{390}$ Idem.
} 
os corruptores de donzelas, as prostitutas, a legião inteira de malformados no físico e no moral, causadores de todas as perturbações da sociedade humana. ${ }^{391}$

Todos esses "tipos degenerados" haviam sido eliminados da sociedade com a prática da eugenia. A classe dos gramáticos aparece nessa lei por opção de Lobato, avesso que era aos padrões linguísticos de sua época. Desde os tempos de estudante anunciava sua repugnância às normas e estruturas da língua. Dizia-se um ignorante do "portuguêsgramática"392 e admitia que guiava-se "pelo faro, como o pescador que sente que ali naquelas pedras há garoupas" ${ }^{\prime 393}$. Devido a isso, muitos dos seus textos eram revisados por Godofredo Rangel e pela redação dos jornais para os quais escrevia. Assumia, portanto, completo horror pela gramática e, consequentemente, pelos gramáticos.

Embora também estivesse submetida ao código da Lei Owen, a raça negra continuou a apresentar alto índice de crescimento, o que alimentava o temor da raça branca em ser sobrepujada. Entrava em ação a fase do grande enigma: "resolve-me ou devoro-te",394. Diante disso, Kerlog via-se obrigado a frear o desenvolvimento da raça negra para a sobrevivência de sua raça. Podemos dizer que, ao elencar os tipos indesejáveis à sociedade norte-americana, Lobato acabava para os perfis sociais brasileiros que precisavam, em sua opinião, ser contidos, quando não exterminados.

Os capítulos que se seguem exploram bem esse olhar pessimista e eugênico do autor. No desfecho da publicação do capítulo XIII, Política de 2228, Miss Astor e Jim Roy encontram-se em uma conferência. A líder feminina deseja seduzir o negro para então obter seu apoio. No entanto, ao perceber a desenvoltura e grandiosidade do líder, decide tocar no seu ponto fraco.

[Miss Astor] Percebeu que tinha diante de si uma força insubornável e inseduzível. E compreendendo a inutilidade dos volteios de onda em torno de rocha tão dura, abordou o assunto de frente:

- O choque das duas raças vai dar-se. Precipita-se, ${ }^{395}$

Com uma frase pela metade e um diálogo apreensivo, Lobato interrompe a sua história na quarta-feira, dia quinze de setembro de 1926. Ora, certa de que seu jogo de sedução não surtiria efeito em Jim Roy, Miss Astor decide jogar sujo a seu favor. Ciente de suas fraquezas, tenta sensibilizar o seu opositor e persuadi-lo com o seu grande temor: o choque das raças.

\footnotetext{
${ }^{391}$ LOBATO, M. O choque das raças. A Manhã: Rio de Janeiro, 14 de setembro 1926, ano II, n. 222. p. 5.

${ }^{392}$ LOBATO, M. A Barca de Gleyre... (t. 1). p. 39. Carta de 03.07.1915.

${ }^{393}$ Idem.

${ }^{394}$ LOBATO, M. O choque das raças. A Manhã: Rio de Janeiro, 14 de setembro 1926, ano II, n. 222 . p. 5.

${ }^{395}$ LOBATO, M. O choque das raças. A Manhã: Rio de Janeiro, 15 de setembro 1926, ano II, n. 223. p. 5.
} 
Entretanto, o leitor fica a ver navios, termina sua leitura diária com mais dúvidas do que certezas. Será que depois dessa Jim Roy irá se render aos argumentos da formosa líder feminina? Por que o choque das raças nas falas de Miss Astor? Até então nada se sabe, mas tudo se imagina. Apenas no dia seguinte a trama iria ser revelada.

Ao décimo dia, seguia o romance:

\begin{abstract}
Será um conflito tremendo - mas só no caso de estar no poder o homem branco, criador do ódio do negro. Tudo mudará se em vez desse implacável inimigo comum, estivermos nós.

Jim Roy franziu os sobrolhos.

- "Inimigo comum, sim, prosseguiu miss Astor. Inimigo da raça negra e inimigo de nós mulheres. Ambas somos suas escravas, mas a escravização dos teus, Jim Roy, data de séculos e a nossa data de milênios. Se o poder supremo vier ter as nossas mãos o choque se atenuará, porque saberemos ser conciliantes. ${ }^{396}$
\end{abstract}

Miss Astor propunha uma aliança com Jim. Entendia que ambos compartilhavam um passado marcado pela opressão e pela escravidão, e, por isso, deveriam somar esforços. Assim, forjava um inimigo em comum por acreditar que a união entre os dois líderes não era só necessária, mas, sobretudo, conveniente. Dessa maneira, tenta chantagear o representante da raça negra, ao sugerir que caso ele não colaborasse com a sua candidatura, as mulheres brancas não iriam apoiá-los nesse inevitável conflito.

Com propostas tentadoras de ambos os lados, a "Pantera Negra",397 para desespero geral da raça branca, decide então "mostrar as suas garras". Jim Roy, consciente do seu poder frente aos dois partidos, toma uma decisão que jamais fora cogitada por seus opositores. Poucas horas antes das eleições, anunciava no Capitólio ${ }^{398}$ as palavras que a raça branca não queria ouvir nem acreditar, "O candidato da raça negra é Jim Roy" ${ }^{, 399}$ ! A surpresa foi enorme. Tanto brancos como negros foram surpreendidos pela notícia. A inesperada decisão de Jim iria elevar ainda mais a temperatura do conflito.

Os Estados Unidos de 2228 entravam em clima de tensão. Nessa encruzilhada, restava para homens e mulheres brancos apenas uma saída, eles teriam que se aliar para conter o avanço dos negros e, consequentemente, preservar a sua supremacia racial. Partido Masculino

\footnotetext{
${ }^{396}$ LOBATO, M. O choque das raças. A Manhã: Rio de Janeiro, 16 de setembro 1926, ano II, n. 224. p. 5.

${ }^{397}$ LOBATO, M. O choque das raças. A Manhã: Rio de Janeiro, 22 de setembro 1926, ano II, n. 229. p. 5.

398 “As eleições do século 23 em nada lembravam as antigas, consistentes na mobilização e reunião dos votantes em pontos prefixado, onde se operava o registro dos votos. Tudo mudara. O eleitor não saía de casa - radiava simplesmente os seus votos com destino à estação central receptora de Washigton. Um aparelho engenhosíssimo recebia-os e apurava-os automática e instantaneamente, imprimindo os totais definitivos na fachada do Capitólio.” LOBATO, M. O choque das raças. A Manhã: Rio de Janeiro, 17 de setembro 1926, ano II, n. 225. p. 5.

${ }^{399}$ LOBATO, M. O choque das raças. A Manhã: Rio de Janeiro, 19 de setembro 1926, ano II, n. 227. p. 4.
} 
e Feminino se uniram novamente em prol da sobrevivência de sua espécie e de seu sangue. “Sim, porque já não se trata de um mero choque político entre duas facções da raça branca. Trata-se da luva que nos acaba de lançar em rosto a raça negra." ${ }^{400}$ Os mecanismos de controle político e social instaurados pela raça branca cairiam por terra abaixo. A eleição de Jim Roy aflorava o ódio dos líderes brancos e despertava a fúria da "águia branca"401.

\section{Razão de sangue}

Lobato parecia trazer questões até então impensáveis, como dissera outrora alguns dos seus biógrafos. Um negro e uma mulher como candidatos à presidência; feminismo; eugenia; Estados Unidos. Isso poderia soar muito estranho para os leitores brasileiros de 1926, certo? Sim e Não! As reportagens e textos da A Manhã, Gazeta de Notícias, Correio da Manhã e da Revista do Brasil revelam que a distância que separava o mundo real daquele ano do mundo ficcional de 2228 não era assim tão grande.

A inesperada candidatura e vitória de Jim Roy as eleições daquele ano atenuaram ainda mais o clima de tensão e de incertezas, foram as faíscas necessárias para acender e explodir o barril do pólvora então formado entre as fronteiras sociais das duas raças. $\mathrm{O}$ sucesso do líder negro é contado no capítulo XVI, O titã apresenta-se. Nele, Miss Jane narra como a segregação política havia contribuído para o triunfo social dos negros e como aconteceu a restauração da aliança entre homens e mulheres brancos em prol da permanência de seu sangue. Juntos, buscavam meios para reprimir o avanço negro que representava perigo à sua raça.

Miss Jane conta que a "loucura das mulheres" em abandonar os homens havia alimentado o grande temor do século, o poderio da raça negra ${ }^{402}$. Elas eram as grandes culpadas pela "revolução negra". O anúncio de Jim Roy despertou em Miss Astor um sentimento de culpa. Ora, se ela não tivesse se separado do homem branco certamente essa catástrofe não teria acontecido. Assim, redescoberto o "sentimentalismo amoroso pelo homem branco" 403 , a primeira medida tomada pelo Partido Feminino foi reconhecer a estupidez em

\footnotetext{
${ }^{400}$ Idem.

${ }^{401}$ LOBATO, M. O choque das raças. A Manhã: Rio de Janeiro, 21 de setembro 1926, ano II, n. 228 . p. 4.

${ }^{402}$ LOBATO, M. O choque das raças. A Manhã: Rio de Janeiro, 19 de setembro 1926, ano II, n. 227. p. 4.

${ }^{403}$ Idem.
} 
ter abandonado seu "velho companheiro sexual"404. Apesar de mau, injusto e opressivo, assumiam que o homem branco sempre fora seu eterno marido; "mal com ele, pior sem ele" ${ }^{\natural 05}$, de agora em diante esse seria o brado das mulheres brancas (com exceção de Miss Elvin, que não abdicou de suas teorias, permanecendo sozinha, sem nenhuma seguidora).

Sentindo-se envergonhada e julgando-se responsável pelo eminente conflito racial, Miss Astor vai ao encontro de Kerlog. Em seu escritório, implora-lhe perdão. Chora, ajoelhase e humilha-se ao homem que outrora considerava era seu maior inimigo.

Ah, Kerlog, que injusta fui contigo recusando a fusão partidária que me propunhas!
E como fui cruel respondendo às tuas leais palavras com anfiguris em linguagem
Sabina! Vejo bem claro agora o nosso erro e, embora reconheço as queixas que a
mulher tem do macho, também reconheço que sem o concurso dele nada valeríamos
no mundo. Bastou um momento de divórcio para que a raça branca se visse nesta
horrível situação: apeada do domínio e à mercê de uma raça de pitecos que, essa
sim, tem contas terríveis a ajustar conosco...

Desta forma, a mulher retorna ao lugar que outrora negara, por livre e espontânea vontade vai ao encontro do homem opressor e subjugador, pois percebera que o caos havia se instaurado devido às suas levianas e ilusórias atitudes de mulher "comum". Infere-se com essas passagens que, para Lobato, a mulher poderia, bem como deveria, ser inteligente e racional, contando que não se intrometesse na política e que se posicionasse sempre a favor do homem, seu milenar e eterno marido. Os fragmentos da personalidade de cada personagem feminina do romance refletem uma posição patriarcal de seu criador, bem como o modo de pensar de uma parcela da sociedade brasileira daquele momento.

O posicionamento irrefletido e irracional das mulheres do Partido Feminino resultara na ascensão de Jim Roy, exclamavam os homens brancos. Almejando acabar de vez com o conflito racial, a Associação Negra havia sugerido apoiar o Partido Masculino caso o líder branco atenuasse a Lei Owen ou dividisse o país entre as duas raças. Propunham uma alternativa, chamada por Miss Jane de "Solução Negra"407.

Queriam a divisão do país em duas partes, o sul para os negros e o norte para os brancos. Alegavam que a América era tanto de uma raça como de outra, visto como saíra do esforço de ambas, e já que não podiam gozar juntas, da obra feita em comum, o razoável era dividir-se o território em dois pedaços. Mas como os brancos

\footnotetext{
${ }^{404}$ Idem.

${ }^{405}$ Idem.

406 Idem.

${ }^{407}$ LOBATO, M. O choque das raças. A Manhã: Rio de Janeiro, 14 de setembro 1926, ano II, n. 222. p. 5.
} 
preferiam continuar no status-quo a resolver o caso por esse processo, o problema racial permanecia de pé, cada vez mais ameaçador. ${ }^{408}$

Essa proposta foi considerada como inadmissível pelo Partido Masculino, que já vislumbrava outra saída. A "Solução Branca" 409 era expatriar homens e mulheres negros para o Vale da Amazônia, para que pudessem se livrar de uma vez por todas de seu maior problema. "Ou expatriamos os negros já, ou dentro de meio século seremos forçados a aceitar a solução negra, asfixiados que estaremos pela maré montante do pigmento."410

Com a vitória de Jim Roy à presidência, cresceu então o entusiasmo entre os negros, que enfim poderiam ter suas aspirações realizadas. Por outro lado, só aumentava a preocupação entre os brancos, que temiam as consequências das ações do líder opositor. Desta forma, surgia uma esfera de tensão nos Estados Unidos de 2228. Inconformados com o resultado das eleições, Kerlog e seus aliados ${ }^{411}$, decidem se reunir na "Convenção Branca" para buscar soluções rápidas e práticas que pudessem resolver o alarmante problema que se apresentava de forma tão escabrosa.

Desta forma, na edição do dia vinte e dois de setembro, décimo quinto dia da publicação do romance, o desfecho é apreensivo. Na Convenção, com exceção do Ministro da Paz, todos concordavam com o seu líder de que a sobrevivência e a supremacia da raça sobrepunham-se a qualquer questão de justiça ou moral. Era imprescindível encontrar uma saída rápida para conter o avanço do elemento negro. Reunidos em assembleia, a "raça branca elaborava o seu voto decisivo..."412 e, assim, determinava qual havia sida a sentença do dia.

Mais uma vez, o leitor iria dormir sem saber quais eram os rumos da história norteamericana do futuro. Repare que Lobato decide, na maioria das vezes, encerrar os dias de publicação em pontos cruciais do enredo. Normalmente, as questões que ficavam em aberto eram aquelas relativas à raça e à eugenia. $\mathrm{O}$ autor, sabiamente, deixava para o final da trama momentos de reflexão e assuntos polêmicos, como é o caso da publicação da conferência entre Miss Astor e Jim Roy. A perspicácia do autor explica mais do que o simples desejo em fisgar o leitor e persuadi-lo a ler no próximo dia. Ela sugere que a intenção maior do romance com os seus desfechos era suscitar questionamentos e reflexão. Ao apresentar os Estados

\footnotetext{
${ }^{408}$ Idem.

${ }^{409}$ Idem.

${ }^{410}$ Idem.

${ }^{411}$ Embora tenha reatado as alianças com o Partido Feminino, nenhuma mulher participa dessa assembleia. O que indica a perda de poder e de voz das mulheres no meio político.

${ }^{412}$ LOBATO, M. O choque das raças. A Manhã: Rio de Janeiro, 23 de setembro 1926, ano II, n. 230 . p. 5.
} 
Unidos eugenizado em 2228, Lobato abria um debate acerca da realidade do Brasil de 1926. Os encerramentos diários são artifícios utilizados pelo autor para não só incitar a curiosidade mas, principalmente, para contribuir com a repercussão e reflexão das ideias ali expostas. Percebe-se, portanto, que nada nesse romance é por acaso. No caso, a dúvida que deveria atazanar o leitor era sobre a solução a ser empreendida. Uma vez declarada a guerra racial pelos brancos, como ela seria travada? Sangue seria derramado? A tensão na história aumentava e, junto com ela, as hipóteses sobre o desdobramento da história.

O clima de tensão seguia o seu curso no dia seguinte. Depois de algumas horas de discussão, a Convenção Branca encontrava uma solução final para o problema do choque das raças. No entanto, essa decisão não nos é conhecida. Miss Jane diz que o sigilo em torno dessa decisão foi tão grande entre os integrantes que nem mesmo o Porviroscópio conseguira decifrá-lo. Ao final da reunião, John Dudley, o homem das 72 invenções, não acreditando na eficácia do recurso escolhido, diz a Kerlog que o comunicasse caso uma dor de cabeça aparecesse:

\begin{abstract}
- Faço votos para que o senhor presidente descubra a solução prática com a mesma facilidade com que o senhor Leland descobriu a solução teórica. Isso lhe trará, talvez, uma certa dorzinha de cabeça. Se por acaso essa dor de cabeça se agravar e não ceder a nenhum sedativo, lembre-se deste seu criado e chame-o. Quero ter a honra de curar uma dor de cabeça histórica... ${ }^{413}$
\end{abstract}

Dudley já tinha em mãos a sua $73^{a}$ invenção. Apesar de confiante de sua infabilidade, esperou que Kerlog viesse a seu encontro para revelar-lhe. Dito e feito. O líder branco, preocupado com o fim de sua raça, não conseguia pensar em outra coisa. Sua cabeça, como adivinhara Dudley, doía cada vez mais, pois a solução encontrada na Convenção Branca não lhe agradava muito, tendo em vista que era mais teórica do que prática. "Será que John Dudley possui, como septuagésima terceira invenção, uma superaspirina?" ${ }^{214}$, questionava-se. Decidido a se livrar dos negros, buscou o remédio de John Dudley. "- A cabeça estala-me e a dor não cede a sedativo nenhum. Acuda-me com a sua ultra-aspirina...”, implorou Kerlog. Ao ouvir as explicações da nova invenção do cientista, as dores cessaram no mesmo instante e um sorriso surgiu em seu rosto.

Convencido da eficácia da "aspirina" do inventor, Kerlog convoca novamente os demais líderes brancos para apresentar a nova e brilhante solução para a pedra no sapato americano. Ainda sem saber maiores detalhes, o leitor caminha para o final da publicação

\footnotetext{
${ }^{413}$ LOBATO, M. O choque das raças. A Manhã: Rio de Janeiro, 24 de setembro 1926, ano II, n. 231. p. 5. ${ }^{414}$ Idem.
} 
quando o homem das $72^{\mathrm{a}}$ invenções revela sua nova descoberta. No capítulo XXI, Uma dor de cabeça histórica, Miss Jane começa a anunciar a "ultra-aspirina" de 2228. No entanto, relata poucos detalhes dessa invenção, faz suspense com Ayrton e com o leitor. Conta apenas que John Dudley vinha se dedicando há alguns anos ao estudo dos cabelos "carapinhas" e ao desenvolvimento de uma fórmula para o seu alisamento. Nos dois dias que se seguem, as publicações dos capítulos XXI e XII, não explicam de fato qual seria a função da invenção de Dudley. Sabe-se apenas que eles têm o poder de alisar o cabelo encaracolado, no entanto, não explica como e porque poderiam solucionar os problemas e conflitos entre as raças.

Importante ressaltar que, naquela época, o negro tinha uma aparência surpreendente, de modo que Jim Roy, por exemplo, "apesar de ter o cabelo carapinha, [era] horrivelmente esbranquiçado" 415 . No vislumbre de Ayrton Lobo, o líder negro era um tipo "barata descascada". Igualmente, todos os negros tinham passado pelo processo de despigmentação da pele, e por procedimentos cirúrgicos a fim de afinar lábios e narinas. Todavia, ainda restava o cabelo liso para se tornarem fisicamente semelhante aos brancos. Desta forma, a $73^{\mathrm{a}}$ invenção, os Raios Ômegas, surgia como uma benção para a raça branca, pois com o pretexto de alisar os cabelos carapinhas acabavam por esterilizar completamente os negros. O leitor curioso podia finalmente descansar. A solução final para o choque das raças foi exatamente essa: após a eleição de um candidato negro (Jim Roy) como presidente dos Estados Unidos, a liderança branca se viu diante de uma única alternativa para o impasse, a esterilização dos negros e seu consequente extermínio.

Sem dor, sem lesão, e, o principal, sem que o paciente sequer suspeitasse, assim era como agiam os Raios Ômegas. Com propriedades de modificar o "cabelo africano", "o mais rebelde pixaim,"416, em liso e sedoso com apenas três aplicações, o produto deixava o cabelo do negro com o aspecto "do mais apurado tipo branco". Desejosos em se igualar à raça superior (branca) os negros, ao saberem da mais nova descoberta, se empolgaram de tal forma que os postos de aplicação não conseguiam acompanhar a demanda. Miss Jane conta que os Raios Ômegas foram vistos pelos negros como um "aperfeiçoamento físico da raça”. Todos, sem exceções, se "omegaram", até mesmo Jim Roy, o homem "símbolo da força", representante da raça negra contra a branca.

Mal repostos ainda da emoção consequente à vitória de Jim Roy, uma outra os empolgava agora - e esta mais fecunda, pois redundaria num aperfeiçoamento real

\footnotetext{
${ }^{415}$ LOBATO, M. O choque das raças. A Manhã: Rio de Janeiro, 14 de setembro 1926, ano II, n. 222. p. 5.

${ }^{416}$ LOBATO, M. O choque das raças. A Manhã: Rio de Janeiro, 29 de setembro 1926, ano II, n. 234 . p. 5.
} 
da raça, num grande passo no caminho de aproximá-los do branco. Já o pigmento fora destruído e, embora o esbranquiçado da pele não se revelasse cor agradável à vista, tinham esperança de, com o tempo, obter a perfeita equiparação cutânea. Vir agora e assim de chofre o resto, o cabelo liso, a supressão do teimoso estigma de Cam, era, não havia dúvida, sinal de um fim de estágio. Reduzidas desse modo as duas características estigmatizantes da raça, o tipo áfrico melhorava a ponto de, em numerosos casos, provocar confusão com o ariano. Entre a miss naturalmente branca e loura e a negra despigmentada e omegada pelo processo Dudley a diferença faziase quase nula. 417

Sem imaginar os resultados desastrosos, a raça negra deleitava-se com o seu mais novo visual ${ }^{418}$, pois o ideal de beleza almejado contemplava as características natas da raça branca. Tanto que todos os negros e negras de 2228 haviam passado por procedimentos que os tornavam fisicamente parecidos, quando não idênticos, aos brancos. A noção de fealdade era atribuída ao pigmento da pele, aos traços largos do rosto e aos cabelos encaracolados. Ter a tez branca era sinônimo de superioridade e beleza. No entanto, o problema aqui apresentado não recaia por completo na aparência física, mas, sim, na essência do ser. Somente o "sangue puro" possuía a verdadeira hegemonia, e, por isso, ambas as raças digladiavam entre si.

A esterilização e o consequente extermínio dos negros, portanto, foi a grande jogada de mestre de Kerlog e John Dudley. Essa solução, no mínimo controversa, nos faz, mais uma vez, refletir e questionar a postura de Monteiro Lobato diante do problema racial e social que se apresentava no momento histórico de criação e concepção de sua obra. Como se constata, o caráter eugenista é latente, é a inteligência "branca" destinada a vencer e se sobrepujar a “negra”. É um hino de louvor à "eugenia negativa”. Os EUA de 2228 apresentava-se como o grande modelo de prática eugênica a ser seguido.

Embora no Brasil a eugenia apresentasse características peculiares, como a predominância dos ideais positivos e preventivos, havia também aqueles que pregavam a prática da eugenia negativa. Renato Kehl, por exemplo, era um dos maiores representantes dessa linha. Para ele,

A esterilização dá resultados na redução dos degenerados; estes resultados, porém, não são imediatos e só se farão sentir após muitos anos de uma execução perfeita e permanente [...] a esterilização é um auxiliar poderoso da redução dos degenerados,

\footnotetext{
417 Idem.

418 Outro ponto em comum entre o romance e os noticiários de 1926, é a solução encontrada pelos brancos de 2228 para acabar com o problema negro: a esterilização através do alisamento de cabelos. Não encontramos nenhuma referência à esterilização de pessoas por intermédio de produtos capilares. Encontramos, porém, propagandas n'A Manhã sobre o produto Antikink, o qual anunciava: "Todos os cabelos podem ser lisos - por mais crespo que seja o Cabelo, por mais rebelde e enrolado, ficará liso e macio usando o "Antikink'”. (cf. Todos os cabelos podem ser lisos. A Manhã: Rio de Janeiro, 8 de agosto 1926, ano II, n. 187. p. 5.) Essas notas sugerem que o cabelo liso era o tipo ideal de beleza e deixam claro que Lobato não estava inovando ou inventando algo. Comprova que ele era um homem informado e que estava por dentro das novidades e inovações de seu tempo.
} 
mas isoladamente não resolve o problema da eugenização da espécie [...]. Em sumo, para melhora física, moral e intelectual dos nossos semelhantes, é necessário lançar mão da esterilização, sem prescindir, porém, da prática dos demais preceitos ditados pela eugenia positiva, preventiva e negativa. ${ }^{419}$

A esterilização, implementada no romance como uma solução para o "problema étnico", era vista por alguns eugenistas como uma importante medida de profilaxia racial para combater os criminosos, os anormais, os inaptos e degenerados, os indicados para os exames $^{420}$. Ainda que a esterilização se apresente como uma medida preventiva para o melhoramento racial, não encontramos nenhuma proposta direta de esterilização dos negros como existe no romance. No entanto, Paula Habib acredita que

a questão do elemento negro na população brasileira preocupava eugenistas,
intelectuais, como Lobato, sob o ponto-de-vista da miscigenação. A necessidade era
classificá-los, sempre tendo como parâmetro o elemento branco, para que pudessem
justificar práticas de exclusão e dominação. Para esses homens da ciência pensar a
identidade nacional era a mesma coisa que pensar a identidade racial e vice-versa.
Procurar realizar o ideal do branqueamento, buscar o indivíduo eugenicamente
perfeito, física e moralmente falando, significava necessariamente excluir o
elemento negro.

O desejo de uma sociedade racialmente homogênea encontrava na esterilização uma via rápida e de fácil acesso. Os tipos a serem saneados eram aqueles que causavam incômodos sociais e algum tipo de degenerescência racial. Embora o negro não apareça nos compêndios eugênicos diretamente relacionados aos perfis a serem eliminados, ele se encontra elencado como uma das espécimes negativas. A preocupação com o negro se encontrava especilamente na miscigenação. $\mathrm{O}$ cruzamento racial era, sobretudo, o fator degenerante da raça porque estragava todas as raças envolvidas. Assim, imbuídos de valores hierárquicos, o estereótipo branco era o parâmetro a ser seguido para se classificar, excluir e dominar o negro.

O romance $O$ Choque das Raças vem demonstrar um posicionamento político de Monteiro Lobato contrário aos negros e seguramente eugenista. Acreditava que enquanto não se praticasse uma política eugenista mais severa e eficiente, o problema da miscigenação continuaria a existir. Embora todas as medidas preventivas e positivas da eugenia tivessem

\footnotetext{
${ }^{419}$ KEHL apud SANTOS, Ricardo Augusto dos. "Eugenia, Saneamento e Educação. O Eugenismo de Renato Kehl (1917-37)”. In: Anais do XI Encontro Regional de História - 2004, Rio de Janeiro, 2004. p. 8. Disponível em:<http://www.rj.anpuh.org/resources/rj/Anais/2004/Simposios\%20Tematicos/Ricardo\%20Augusto\%20dos\%2 OSantos.doc > Acesso em março 2014.

${ }^{420}$ SOUZA, Vanderlei Sebastião de. A “eugenia negativa” nos trópicos: a política biológica e a construção da nacionalidade na trajetória de Renato Kehl (1928-1932). XII Encontro de História Regional. Rio de Janeiro, 2006b.

Disponível

em: $<$ http://www.rj.anpuh.org/resources/rj/Anais/2006/conferencias/Vanderlei\%20Sebastiao\%20de\%20Souza.pdf> Acesso em abril 2015.

${ }^{421}$ HABIB, Paula A. B. B. op. cit., p. 103.
} 
sido colocadas em práticas, foi somente com a execução máxima da eugenia negativa que o problema norte-americano da história de Lobato foi enfim resolvido. No Brasil, o problema social tinha características próprias. A escravidão, embora abolida, ainda estava presente. Não nos moldes do trabalho servil e da subjugação do negro pelo branco, mas, sobretudo, na negação de uma identidade social miscigenada, e na visão racialista de que o negro era degenerado e que precisava ser eliminado da sociedade. A cultura política de outrora (escravagista) ainda se fazia presente nas mentalidades de homens e mulheres do início do século XX.

Portanto, não é difícil imaginar que muitas pessoas daquela época compactuavam com esses princípios eugênicos e desejavam um porvir mais branco e mais eugenizado. $\mathrm{O}$ extermínio da raça negra apresentado n'O Choque ao mesmo tempo em que podia causar espanto e indignação, podia ganhar apreciadores. As falas de Kerlog são significativas para se compreender esse ideal, uma vez que, para o líder branco, os Raios Ômegas não constituíram uma traição, mas, sim, uma razão de sangue ${ }^{422}$.

No capítulo XXIII, A derrocada de um titãa, o líder branco encontra-se com o líder negro para "friamente assassinar com a palavra que mata o negro que há em Jim Roy...". Kerlog, num encontro apreensivo e carregado de simbolismo, revela a Jim a verdadeira ação dos Raios Ômegas.

- Tua raça foi vítima do que chamarás a traição do branco e do que chamarei as razões do branco.

O líder negro pôs-se de pé.

- Traição... E o presidente Kerlog justifica a traição!...

- Não justifico; consigno. Não há traição quando é preciso vencer.

Jim sorriu com desprezo.

- A moral branca!...

- Não há moral entre raças, como não há moral entre povos. Há vitória ou derrota. Tua raça morreu, Jim...

O negro imobilizou-se. Seus olhos se arregalaram. Suas narinas entraram a tremer. $[\ldots]$

- [...] Os raios de John Dudley possuem virtude dupla. Ao mesmo tempo que alisam os cabelos... [...]

$-\ldots$ esterilizam o homem. ${ }^{423}$

A implacável frieza e orgulho com que Kerlog anuncia a "morte" da raça negra são impactantes. Trazem à tona uma perspectiva que extrapola a visão científica, pois era uma questão moral atinente à integridade da raça branca, o que valeria a sua sobrevivência.

\footnotetext{
${ }^{422}$ LOBATO, M. O choque das raças. A Manhã: Rio de Janeiro, 22 de setembro 1926, ano II, n. 229. p. 5

${ }^{423}$ LOBATO, M. O choque das raças. A Manhã: Rio de Janeiro, 29 de setembro 1926, ano II, n. 234 . p. 5.
} 
Justiça, nesse caso, no combate entre raças, não existia e muito menos interessava. O que havia era vitória ou derrota, e dessa vez a raça negra sucumbia: “[...] o Sangue está acima da justiça. O Sangue tem a sua justiça." ${ }^{424}$. Acima da América estava o "sangue”. A traição da raça branca é, então, redimida pela moral do sangue e da raça, nas palavras de Kerlog.

Os parágrafos finais desse dia de publicação não apresentam clímax, mas a perturbadora revelação em si já cria uma grande expectativa para o dia seguinte. Nas vésperas da posse do novo presidente, Jim Roy aparece morto em seu gabinete, tudo indica que cometera suicídio. Novas eleições são feitas e Kerlog se reelege assumindo o posto de $88^{\circ}$ Presidente da República dos Estados Unidos. A esterilização da raça negra nunca foi revelada, entretanto, para justificar a diminuição das taxas de natalidade, Kerlog anunciou a inclusão "do pigmento negro camuflado" 425 entre as taras que implicavam esterilização por meio da Lei Owen.

Se no desfecho de seu romance Lobato sugeria para os Estados Unidos a esterilização de homens e mulheres negras como uma medida eugênica factível, qual seria, então, o seu conselho para o Brasil? Como proceder se aqui as raças não haviam se separado, mas sim se imiscuído uma na outra? Esse final, que chocou muitos e que por isso é digno de um silêncio quase secular, tem por trás de si uma interpretação aparentemente complexa, mas possível. A lógica narrativa na qual o futuro era lugar de verdade e de certeza, e o presente espaço de dúvida e questionamento, é compreendida em sua totalidade neste último capítulo. A incerteza no presente do Brasil miscigenado de 1926 serviria como lugar de reflexão porque era passível de interferência humana e científica. Assim, Lobato sugere para o seu país uma medida diferente daquela empregada nos Estados Unidos. O beijo final entre Miss Jane e Ayrton Lobo sugere mais do que um mero enlace. Sem grandes detalhes, ele constitui um enigma a ser decifrado pelos leitores. Portanto, no capítulo seguinte, veremos que o encerramento do romance foi uma estratégia inteligentemente arquitetada por Lobato e que possui alguns sentidos. Como já visto, $O$ Choque das Raças não tem nada fora do lugar ou sem uma intenção primeira de ser e com o beijo não seria diferente.

\footnotetext{
${ }^{424}$ LOBATO, M. O choque das raças. A Manhã: Rio de Janeiro, 22 de setembro 1926, ano II, n. 229. p. 5

${ }^{425}$ LOBATO, M. O choque das raças. A Manhã: Rio de Janeiro, 1 de outubro 1926, ano II, n. 237. p. 5. Disponível em: <http://memoria.bn.br/DocReader/docreader.aspx?bib=116408\&PagFis=1215>. Acesso em dezembro 2015.
} 


\section{Capítulo 3: 0 beijo}

Os múltiplos Lobatos estiveram atrelados, mesmo que de forma às vezes dúbia, às lutas que buscavam solucionar as questões sociais, políticas e econômicas que assolavam o Brasil. Em sua máquina de escrever, atacou, maldisse e acusou os responsáveis pela desfiguração do povo brasileiro. Com o Jeca, seu primogênito, denunciou os atrasos da medicina e a negligência do governo. Pediu-lhe perdão por tê-lo julgado tão mal sem saber as reais causas de seus problemas. O pedido, contudo, não significou a aceitação do Jeca e do brasileiro em geral, pois ele continuou atacando a composição racial do Brasil. Se o que perturbava o desenvolvimento do Jeca era a falta de higidez, em $O$ Choque a miscigenação será devidamente condenada porque era vista como a grande causa da degeneração racial da população. Se antes proclamava a favor do saneamento, agora só havia um meio para modernizar o país, a eugenia! Lobato se valeu de um romance futurista-eugenista para divulgar a "ciência do dia", e convencer a população da urgente necessidade de pôr em pratica as ideias eugênicas. Para tanto, se utilizou do meio de comunicação mais comum e prático para atingir as camadas sociais mais populares. Publicou $O$ Choque das Raças no vespertino carioca $A$ Manhã e propagou, em dose homeopáticas, a doutrina que tinha como finalidade "o aperfeiçoamento físico e moral da espécie humana"426.

$O$ Choque trouxe à tona questionamentos relacionados à realidade brasileira, bem como discutiu fundamentos e teorias aplicáveis ao seu contexto histórico. Embora tenha introduzido a ciência por meio de visões futurísticas de uma máquina do tempo, Monteiro Lobato criou um mundo aos moldes de uma "sábia ciência". Nesta obra ele propôs-se a divulgar um modelo ideal de eugenia, tendo em vista a existência de múltiplas interpretações sobre o tema. Didaticamente, o autor ensinou a sua personagem principal e a seus leitores os preceitos da vertente eugênica que lhe parecia mais plausível. Demonstrou que, mais do que a união entre as eugenias preventiva e positiva, urgia-se a necessidade de executar a negativa, a única capaz de resolver os problemas nacionais e colocar o país nos trilhos do progresso e do aprimoramento racial. Para ele, assenhorar-se desse debate, mais do que um dever, era, sobretudo, um ato genuinamente nacionalista, pois a eugenia sugeria um porvir melhor para as seguintes gerações e, consequentemente, para o país como um todo.

\footnotetext{
${ }^{426}$ BARRETO, L. P. Resenha do mês - Eugenia. Revista do Brasil: São Paulo, Volume VII. Janeiro - Março, 1918. Ano III ( $\left.{ }^{\circ} 26-28\right)$, p. 415.
} 
Ao sugerir a eugenia negativa, o autor também propôs modos e meios para sua implementação. Como um "evangelista da harmonia social" 427 , pôs-se a pregar a doutrina eugênica como a única solução possível para o dilema racial brasileiro. Nesse contexto, o objetivo desse capítulo é delinear as propostas do autor, e entender como elas foram apresentadas aos leitores em seu único romance. A construção de uma narrativa permeada pelo presente e futuro constitui um dos artifícios utilizados pelo escritor, pois, de forma sutil e dissimulada, ele propõe uma alternativa radical para uma questão tão controversa. O beijo final entre Miss Jane e Ayrton Lobo sugere mais do que um desfecho feliz e romântico. De forma ambígua, a conclusão do romance é suscetível a diferentes interpretações. Os últimos capítulos, Crepúsculo e $O$ Beijo de Barrymore, de forma apressada, encerram a história com a descrição do desfecho do choque das raças e do enlace entre Ayrton Lobo e Miss Jane. Em $O$ Beijo de Barrymore, Miss Jane decide ceder-se ao seu aprendiz com um enigmático beijo. Esse aparente desfecho romântico tem por trás uma intenção doutrinária que exploraremos melhor a seguir.

Assim, o propósito fundamental deste capítulo é esclarecer porque o beijo é um enigma a ser decifrado. Para tanto, faz-se necessário compreender o desfecho de $O$ Choque à luz das teorias raciais do período, bem como elencar possíveis interpretações para a obra. Importante ressaltar que o termo raça, aqui analisado, não é um conceito "fechado, fixo e natural". Antes, trata-se de um conceito multifacetado com sentidos e significados os mais diversos, moldados em contextos históricos específicos, ou seja, a definição de raça é uma invenção do tempo, é um fenômeno histórico ${ }^{428}$.

\section{Os "evangelistas da harmonia social"}

Incumbida de solucionar os problemas raciais, a eugenia ganhou terreno e voz nas terras tropicais no início do século XX. A missão de uma parcela dos intelectuais era propor e identificar as diferenças inerentes de sua população. Os negros, os indígenas e os mestiços passaram a ser vistos como a escória do povo brasileiro e a sua inferioridade era entendida como resultado das determinações geográficas. Os eugenistas almejavam sanear o país e viam na eugenia o "meio mais rápido e eficiente para 'moldar o plástico organismo humano',

\footnotetext{
${ }^{427}$ KEHL, Renato. Eugenia e medicina social (problemas da vida)... p. 18-19.

${ }^{428}$ SCHWARCZ, Lilia Moritz. op. cit., p. 17.
} 
protegendo 'as gerações futuras da delinquência' e encurtando 'as arestas da imperfeição",429. Nesse sentido, a implementação da "ciência do dia", expressava o verdadeiro caminho rumo à regeneração racial e social do país. Em busca de um caráter genuinamente nacional, a ciência de Galton ganhou espaço e voz nas terras tupiniquins.

No entanto, sabemos que essa ciência não pode ser definida em um único paradigma e que, tampouco, conforma um sistema de pensamento homogêneo e uniforme. Sua relação com o movimento sanitarista foi tão simbiótica que um confundia-se com o outro quando o assunto era penetrar o pensamento social e político local. Uma "ciência poliforma"430, a eugenia era uma "forma de conhecimento cuja constituição se processou a partir da relação direta com outros ramos do pensamento científico e social" ${ }^{\prime 31}$. Orientada pelos conhecimentos biomédicos, sociológicos, pedagógicos, geográficos, demográficos e antropológicos, era classificada como uma "ciência bio-social", isto é, mesclava, especialmente, as áreas biológicas e sociais. Assim, o movimento eugênico promoveu amplas discussões sobre projetos de reforma social, mobilizou diversos setores da sociedade, e conquistou diversos seguidores, entre os quais havia intelectuais, jornalistas, literatos, advogados, médicos e políticos atrelados aos discursos médicos e sanitaristas. Com perspectivas diferentes e complementares, a eugenia apresentava-se aos brasileiros como alternativa para se alcançar o sucesso do aprimoramento racial.

Monteiro Lobato participou de forma ativa nesse debate. Utilizou a literatura como instrumento de divulgação e doutrinação das teorias que considerava importantes para a ressureição do país. Deste modo, se apropriou das letras para informar, justificar e apresentar ideias e razões lógicas para salvar o Brasil. O Choque das Raças é o exemplo mais bemacabado dessa, nem sempre lembrada, faceta lobatiana. Nesse romance, ele se dispõe tanto a ensinar os leigos e ignorantes no assunto, como a convencer os já conscientes do debate sobre qual seria a mais "sábia" eugenia. O texto literário permitia uma abordagem peculiar sobre o problema, como visto no capítulo 2. Na narrativa, Ayrton Lobo incorpora o papel do leitor leigo. Inicialmente, o próprio termo eugenia soara-lhe estranho, pois jamais cogitara a sua existência. Mais adiante, a partir do capítulo X, passa a demonstrar certo conhecimento no assunto e se a sentir seguro para expressar suas opiniões. Contudo, seus conhecimentos, de acordo com Miss Jane, ainda eram típicos de um "homem comum", daquele que ouve e

\footnotetext{
${ }^{429}$ SOUZA, Vanderlei Sebastião de. Em nome da raça..., p. 36

${ }^{430}$ Ibidem, p. 40.

${ }^{431}$ Idem.
} 
acredita como verdade sem antes refletir e criticar. A professora deveria, portanto, seguir firme na sua missão de conduzir seu aprendiz na jornada da razão.

Ao refletirmos sobre os recursos narrativos empregados por Lobato em seu romance, uma série de questionamentos surge para tentar explicar o porquê de suas escolhas. Como já foi dito, está claro que o literato buscava divulgar a eugenia e torná-la mais acessível às camadas excluídas do debate acadêmico, sendo essa a razão de ter ele optado por publicar $O$ Choque num jornal de grande circulação. No entanto, se Ayrton representa a população de uma forma geral, quando ele passa a demonstrar interesse no debate racial, mesmo que inicialmente contrário ao posicionamento de Miss Jane, questionamos se, de fato, a eugenia era uma teoria circunscrita apenas ao meio intelectual. Caso contrário, o que poderia tê-lo informado sobre esse debate? Lobato estaria reproduzindo de forma planejada ou seria o debate um assunto comum entre homens daquele período? O literato estaria inovando ao se utilizar do periódico como o meio mais eficaz para a divulgação dos ideais eugênicos?

Não, o escritor paulista, mais uma vez, não estava inovando nem sendo um homem a frente de seu tempo, como muitos gostam de ilustrar. Sabemos que muitos dos debates científicos daquela época ficavam restritos a uma pequena parcela intelectualizada da população, permanecendo circunscritos aos meios acadêmicos, tais como os congressos e conferências nacionais das Faculdades de Medicina e Direito da Bahia e São Paulo ${ }^{432}$. Todavia, é possível também encontrar, sem grandes dificuldades, o debate racial nas páginas da grande imprensa. Pietra Diwan demonstra como os temas médicos eram comuns no cotidiano dos paulistas ${ }^{433}$ e como a Sociedade Eugênica de São Paulo se apropriou da esfera pública para divulgar suas ideias. O Estado de S. Paulo, por exemplo, em 27 de junho de 1919, comemorou a fundação dessa Sociedade:

É digno de nota o que se passou ontem na Sociedade Eugênica de São Paulo. Devia entrar em discussão uma das questões mais apaixonadas e mais debatidas de que temos notícia em São Paulo, nestes últimos tempos: a consanguinidade e o casamento. [...] Uns e outros sustentando os respectivos pontos de vista discutiram o assunto sem paixão e sem intolerâncias, mas com calma, com serenidade, com vontade de acertar. [...] foi uma noite memorável a de ontem. ${ }^{434}$

O interesse da imprensa pelas causas médicas contribuiu diretamente para a propagação do assunto, especialmente em São Paulo. Os textos eram lidos pelas camadas

\footnotetext{
${ }^{432}$ SCHWARCZ, Lilia Moritz. op. cit., p. 191.

${ }^{433}$ DIWAN, Pietra. op. cit., p. 99.

${ }^{434}$ Idem.
} 
letradas de múltiplos setores da sociedade, e ganhavam grande repercussão e credibilidade ${ }^{435}$. Contudo, Diwan considera que O Estado de S. Paulo teve um "certo beneficiamento de informação no que diz respeito à Sociedade Eugênica de São Paulo" ${ }^{\text {"46, }}$, graças ao grau de parentesco existente entre Viera de Carvalho e Júlio Mesquista, respectivamente diretores do vespertino e da associação.

A preocupação com as questões de consanguinidade, casamento, miscigenação não foi exclusiva deste periódico. A Gazeta de Notícias e o Correio da Manhã também estamparam em suas páginas textos de grandes nomes da eugenia, assim como disseminaram propagandas de livros e encontros da Sociedade Eugênica de São Paulo e da Liga Brasileira de Higiene Mental. Constatou-se que ambos boletins apresentam inúmeras citações e ocorrências relativas às questões higienista e sanitarista ${ }^{437}$. Mais do que isso, verificou-se que por trás dos diversos pontos de vista emitidos sobre o assunto, existe um mesmo núcleo essencial: a limpeza social.

Durante o ano de 1923, semanalmente, Renato Kehl escreveu para a Gazeta de Notícias. É nítida a intenção do autor em divulgar e ensinar os preceitos da eugenia. Por intermédio de textos simples e objetivos, o autor buscava demonstrar que a ciência poderia ser aliada do desenvolvimento do homem e, consequentemente, da nação. Em março publicou o texto Hominicultura ${ }^{438}$ no qual ele comparava a ciência do melhoramento genético dos animais (puericultura) com os seres humanos, e demonstrava ser possível em alguns séculos sua implementação nas sociedades. Um mês depois, escreveu outro artigo, O homem purosangue 439 , explicando como e porque a eugenia era o "estudo e aplicação das questões de hereditariedade, descendência e evolução", que tratava igualmente das questões "relacionadas à influência do meio, do estado econômico, da legislação, dos costumes". Para atingir um certo grau de aperfeiçoamento social, ele acreditava na necessidade de selecionar os indivíduos que necessitavam ser eliminados daqueles que mereciam ser conservados. $\mathrm{O}$ homem puro-sangue, "equilibrado, normal, eugenicamente perfeito" era o tipo ideal a ser seguido e disseminado na sociedade. Segundo Kehl, naquele momento a eugenia era "a

\footnotetext{
${ }^{435}$ Idem.

${ }^{436}$ Idem.

${ }^{437}$ Infelizmente, todas essas ocorrências não foram possíveis de análise devido ao pequeno espaço de tempo de pesquisa. Segundo o portal online da Biblioteca Nacional, o jornal Gazeta de Notícias apresenta cerca de 4.375 ocorrências sobre higienismo entre 1920 e 1929. O Correio da Manhã, mais de 8.000.

${ }^{438}$ KEHL, Renato. Hominicultura. Gazeta de Notícias: Rio de Janeiro, 15 de março de 1923, ano XLVIII, n. 62, p. 1. Disponível em: <http://memoria.bn.br/DocReader/docreader.aspx?bib=103730_05\&PagFis=8263 >. Acesso em janeiro de 2016.

${ }^{439}$ KEHL, Renato. O homem puro-sangue: a possibilidade da sua criação... p. 1.
} 
doutrina a ser esposada", porque não era apenas "uma questão de interesse individual [...], mas, sobretudo humano, e de ordem social, nacional e internacional". Digno de nota é a localização privilegiada desses textos, todos centralizados na parte inferior da primeira página do jornal, o que denota a importância dispensada ao assunto pela redação da folha.

Apesar da publicação do romance $O$ Choque das Raças n'A Manhã, constatamos poucos textos que corroboravam os preceitos eugênicos nesse diário. Deparamo-nos principalmente com chamadas pequenas, como as dos congressos sobre Higiene e Sanitarismo em Buenos Aires, pequenos relatos sobre os encontros da "Liga de Higiene Mental", e mais frequentemente notas sobre postos de vacinação contra a varíola. Há também algumas matérias que reivindicam a assistência governamental para desenvolver o sistema de saneamento básico nos subúrbios. No dia 23 de abril de 1926, em $O$ descalabro sanitário no Brasil $^{440}$, o autor Maurício de Medeiros revelava as péssimas condições de inspeção sanitária realizadas pela diretoria da secretaria de Saúde Pública do Rio de Janeiro e as ações suspeitas do médico Carlos Chagas e da Instituição americana Rockefeller. Demonstra o total abandono de causa frente às epidemias que se alastravam no país.

A febre amarela está matando brasileiros no interior do país, e o Sr. Chagas, depois
de ter concordada com a cruel doutrina de extinção automática dos foco, sorrirá
certamente de novo... Os brasileiros, que estão morrendo, são pobres jecas, talvez
papudos ou cretinos, cuja vida se fez apenas para aureolar a glória do Sr. Chagas, e
cuja morte é uma colaboração à sua promessa de próxima extinção da mitológica
doença de Chagas. Quando o mal chegar até nós - 'quo Deus avertat' - então sim,
chegará a hora do ajuste de contas, e talvez, se o Sr. Chagas não estiver deleitando-
se em Paris, não lhe sobre tempo para sorrir... Força é convir, porém, que detestável
é o sistema de governo no qual o menor dos parasitas da casta governamental tanto
pode contra interesses tão respeitáveis de toda a Nação. ${ }^{441}$

O médico e jornalista denunciava o abandono das cidades do interior do país, o descaso do sistema de saúde e as falsas promessas do governo. Delatava o médico Carlos Chagas e a Instituição Rockefeller por haver desamparado as pequenas cidades. De acordo com a Instituição, regiões com menos de 19.000 habitantes não precisavam de assistência contra a febre amarela, pois "os focos infecciosos em localidades menos populosas extinguem-se por si [...] e extinguem-se pela morte dos que terá de morrer e pela imunização dos que sobrevivem" ${ }^{442}$. Essa e outras justificativas não poderiam ser aceitas, bradava Medeiros. A morte de brasileiros em nome da saúde de outros não se justificava. A Manhã

\footnotetext{
${ }^{440}$ MEDEIROS, Maurício de. O descalabro sanitário no Brasil. A Manhã: Rio de Janeiro, 23 de julho de 1926, ano II, n. 177, p. 3.

${ }^{441}$ Idem.

${ }^{442}$ Idem.
} 
apoiou essa e outros tipos de denúncias. Publicou também cartas de descontentamento emitidas pela população. Em agosto do mesmo ano, com a chamada Defendamos os subúrbios: calçamento, água e higiene para a avenida Suburbana ${ }^{443}$, um leitor denunciou a falta de saneamento básico na região suburbana e reivindicou por maiores ações governamentais. Vê-se, portanto, que nesse periódico os aportes estruturais relacionados ao sanitarismo e à eugenia preventiva tinham maior proeminência em relação à Gazeta de Notícias, por exemplo.

Contudo outras matérias d'A Manhã nos chamaram a atenção. Embora não abordem questões eugênicas propriamente ditas, demonstram como a direção e a redação poderiam tomar partido no polêmico debate racial. Com repercussão por três dias consecutivos no mês de julho de 1926, o caso do Jockey Club expressa bem o que queremos dizer. O autor (desconhecido) em tom denunciatório, critica o posicionamento preconceituoso do diretor da instituição que se negara aceitar "como empregados homens de cor!"444. Interessante é o tom do texto, no qual o delator, indignado, denuncia o estabelecimento e o seu diretor, Sr. Linneu Machado. A denúncia foi estampada e centralizada na primeira página do jornal, com destaque para a seguinte chamada: “O Jockey-Club não admite, como empregados, homens de cor! Uma injúria cuspida à face de milhares de brasileiros”, e continua:

\begin{abstract}
No Brasil não deve, não pode haver seleção de cor. A morte do preconceito de raça entre nós é a nossa mais gloriosa conquista espiritual. Porque por ela é que revelamos a profundeza da nossa consciência. Por ela é que contraprovamos a rijeza de nossa individualidade moral. Quando dizemos que o homem de cor é nosso irmão genuíno, não estamos fazendo vã retórica. Ele sofreu conosco, sofreu por nós e para nós. Tem sido, ao nosso lado, o lutador infatigável, a cujo concurso devemos muito do que somos. 445
\end{abstract}

Esse trecho demonstra que dissertar sobre preconceito em 1926 não é anacronismo. Embora o Brasil fosse, nesse momento, um país recém-saído da escravidão, com um passado pulsando de forma latente e viva, encontramos discursos em prol dos negros e a favor da miscigenação figurando ao lado de hinos dos mais eloquentes racismos. Falar sobre raça naquele momento também significava pensar em diferentes possibilidades de interpretação e, algumas delas eram positivas e favoráveis aos homens de cor e à mistura entre raças. Mas, é de se notar que a denúncia é em prol da reivindicação do espaço do negro como servidor

\footnotetext{
443 Defendamos os subúrbios! Calçamento, água e higiene para a avenida Suburbana. A Manhã: Rio de Janeiro, 21 de agosto de 1926, ano II, n. 202, p. 5.

${ }^{444}$ O Jockey-Club não admite, como empregados, homens de cor! A Manhã: Rio de Janeiro, 01 de julho 1926 , ano II, n. 158. p. 1.

${ }^{445}$ Idem.
} 
braçal e não como usuário privilegiado daquele recinto. Assim, "nem negro, nem mulato" "446 eram bem-vindos como trabalhadores daquele espaço de gente branca.

Outra história que nos interessou foi a de um menino negro de 15 anos que fugiu do Instituto Profissional João Alfredo ${ }^{447}$ e foi até a redação do jornal denunciar "as pancadas dos maiores e os outros sofrimentos" ${ }^{448}$. Essa reportagem nos leva a refletir sobre as formas de acesso ao jornal, os diferentes perfis de seus leitores, os diversos posicionamentos perante o debate racial do momento, e as múltiplas formas de recepção deste controverso assunto. Ora, esperto como foi, depois de fugir, Waldemiro Caldas temeria contar a sua história para qualquer um. A partir do ponto de vista crítico, podemos questionar por que o menino não procurou imediatamente a ajuda da polícia. Mas, se pararmos para refletir um pouco melhor, algumas incertezas surgirão, tais como: qual punição o estatuto da Instituição previa para os internos fugidos? A polícia o ampararia da mesma forma como o fez A Manhã $?^{449}$ Por que o jornal acolheu o Waldemiro? ${ }^{450}$ Provável seja que o menino soubesse do acolhimento de sua causa por parte desse periódico, uma vez que suas matérias demonstravam apoio aos menos favorecidos da sociedade.

Apesar de Lobato ter publicado n'A Manhã um romance eugenista, também podemos encontrar nesse jornal textos com ideias contrárias ao preconceito na sociedade, como as mencionadas acima. A ambiguidade que provoca a existência de textos com discursos tão distintos não nos permite estabelecer uma característica ideológica específica para A Manhã. Embora advogasse ao lado dos negros e dos menos favorecidos, isso não significava que o periódico e os seus diretores concordassem com a igualdade racial. Ao denunciar a atitude preconceituosa do Jockey-Club e ao defender os meninos do Instituto Profissional João Alfredo, o diário estava apenas reivindicando o lugar de cada um na sociedade, bem como os

\footnotetext{
${ }^{446}$ Idem.

447 "O IPJA foi, anteriormente, o Asilo de Meninos Desvalidos, um estabelecimento pensado e estruturado para funcionar como casa, escola e oficina, tendo como propósito abrigar, educar e profissionalizar meninos pobres ou órfãos em regime de internato, na faixa etária compreendida entre seis e doze anos de idade. Funcionou de 1875 a 1894, na Chácara dos Macacos, na cidade do Rio de Janeiro. Em 1894, com o objetivo de dar ênfase à profissionalização de seus alunos, passou a denominar-se Instituto Profissional." Para mais informações, conferir: SOUZA, Maria Zélia M de S. Governo de crianças: o Instituto Profissional João Alfredo (1910-1933). Hist. Educ. (Online). Porto Alegre, v. 16, n 38, set./dez. 2012. p. 151.

${ }^{448}$ A vida trágica dos pequeninos párias! Farto de maus tratos, fugiu do Instituto 'João Alfredo'. A Manhã: Rio de Janeiro, 28 de julho de 1926, ano II, n. 181.p. 7.

${ }^{449}$ Vale lembrar que depois desse caso outros surgem e o jornal começa a querer investigar o IPJA.

450 Dois dias depois, aparecerá outra publicação sobre a "vida trágica dos pequenos párias". A Manhã empreendeu uma campanha contra o Instituto João Alfredo, denunciando os maus tratos e péssimas condições da infraestrutura do local. Cf.: Uma jaula de feras para os pássaros indefesos. A Manhã: Rio de Janeiro, 06 de agosto de 1926, ano II, n. 189. p. 1; e Ainda o Instituto João Alfredo e a sua história escabrosa. A Manhã: Rio de Janeiro, 11 de agosto de 1926, ano II, n. 193. p. 1-2.
} 
direitos salvaguardados e previstos em lei. Apesar de se posicionar contrário às injustiças raciais e sociais, A Manhã também lutava em causa própria. A publicação de $O$ Choque das Raças em suas páginas não significava que esse periódico possuía um caráter eugenista, mas pode nos indicar que Mário Rodrigues visava angariar um maior público com as polêmicas que poderiam se constituir em torno do romance lobatiano.

De fato, o tema eugenia, propriamente dito, não foi debatido de forma direta por esse periódico carioca, entretanto, temas correlatos como sanitarismo e preconceito racial, ocuparam frequentemente as suas páginas. Paula Habib não descarta a possibilidade de que os redatores d'A Manhã estivessem de comum acordo com as ideias pregadas no romance, e complementa dizendo ser plausível a ideia de que as chamadas publicitárias da obra tenham sido escritas e financiadas pelo próprio Lobato ${ }^{451}$. Não desconsideramos nenhuma dessas alternativas, pois já demonstramos a proeminência e a importância deste debate e a maneira pela qual Lobato se apropriou de suas múltiplas facetas para alavancar sua carreira de literato.

Como pode-se ver, a imprensa, de alguma forma, deu espaço para os debates sobre a eugenia e, mais do que isso, "elogiou e registrou a formação dessa área de saber, e acompanhou a discussão sobre os problemas nacionais acerca da composição racial da população brasileira" ${ }^{452}$. Todavia, nos questionamos sobre as formas de acesso à informação no início dos anos 1920 e sobre o perfil do público leitor que acompanhava os noticiários jornalísticos. Nos primeiros anos do século XX, o Rio de Janeiro tinha aproximadamente 1,4 milhões de habitantes, e destes mais ou menos $20 \%$ eram alfabetizados ${ }^{453}$. De acordo com Maria Alice R. de Carvalho ${ }^{454}$, havia cerca de vinte jornais diários para informar toda essa gente. Não podemos discriminar a condição social desses vinte por cento, porém, estes dados nos levam a crer que a maior parte do público destes periódicos era composto por indivíduos letrados e com certo nível de esclarecimento. No entanto, não podemos deixar de lado um grupo de "leitor", ou melhor, de ouvinte. Importante lembrar da existência de rodas e reuniões onde um ou mais leitores liam em voz alta para aqueles que não sabiam ler e escrever, informando-o dos ocorridos e, principalmente, colocando-os a par das histórias de folhetins. Sem evidências disso, não podemos mensurar o público leitor de $O$ Choque das Raças nem as maneiras pelas quais foi interpretado.

\footnotetext{
${ }^{451}$ HABIB, Paula A. B. B. op. cit., p. 90.

${ }^{452}$ DIWAN, Pietra. op. cit., p. 99.

${ }^{453}$ DE LUCA, Tânia R. op. cit., p. 159.

${ }^{454}$ Em São Paulo, 24\% da população sabia ler e escrever. CARVALHO, Maria Alice R. de. op. cit., p. 72.
} 
Sabe-se, portanto, que os jornais tinham grande circulação entre as camadas pobres da sociedade brasileira, pois eram de fácil acesso, mais baratos, e, principalmente, porque incorporavam temas populares ${ }^{455}$, tais como os resultados do jogo do bicho e as notícias de assuntos variados sobre o cotidiano da sociedade. Por atingir um número considerável de leitores, muitos viam no jornal um meio de divulgação propício à disseminação de suas ideias. Por isso, havia em alguns autores e textos um anseio pela "domesticação das classes pobres" 456 , um desejo de doutrinação desse estrato social. A eugenia, por exemplo, apropriouse da imprensa a fim de atingir uma parcela da população cada vez maior.

Todavia, sua eficácia ainda é incompreensível em alguns âmbitos, do mesmo modo que a eugenia.

\begin{abstract}
Sabe-se que é de grande importância a adesão da imprensa, pois os maiores representantes da comunidade médica publicavam nos jornais de grande circulação (Jornal do Comércio, O Estado de S. Paulo, Correio Paulistano etc). Esses artigos eram lidos pela elite em diferentes setores da sociedade com imensa repercussão e credibilidade. $^{457}$
\end{abstract}

Embora encontremos muitos textos que abordam essa temática, não podemos delimitar o seu raio de acesso, nem como foram lidos e interpretados. Apesar da ampla divulgação do tema nos jornais da época, não conseguimos mensurar quais dos leitores eram eruditos e quais não. Contudo, Nancy $\operatorname{Stepan}^{458}$ diz que as discussões eugênicas não atingiram todas as camadas sociais do Brasil, e que as elites intelectualizadas estavam muito mais informadas sobre o caminhar científico europeu, o que lhes possibilitou uma rápida assimilação das teorias $\operatorname{racistas}^{459}$ e, consequentemente, da eugenia. Essas evidências sugerem que, provavelmente, $O$ Choque das Raças teve maior repercussão entre o público intelectualizado do que nas camadas sociais mais pobres.

Contudo, a divulgação do movimento eugênico para além dos círculos acadêmicos fica evidente quando encontramos textos em diferentes jornais e revistas do início do século XX. Desejando ampliar o alcance de suas teses, nomes importantes desse grupo, como Renato Kehl, Belisário Penna e Oliveira Viana, publicaram textos introdutórios na imprensa como forma de popularizar seus preceitos. A linguagem acessível demonstra mais do que uma intenção em ampliar o debate, mas, principalmente, em apresentar a norma de conduta

\footnotetext{
${ }^{455}$ Ibidem, p. 15.

${ }^{456}$ Idem.

${ }^{457}$ DIWAN, Pietra. op. cit., p. 99.

${ }^{458}$ STEPAN, Nancy Leys. A hora da Eugenia... p. 106.

${ }^{459}$ HABIB, Paula A. B. B. op. cit., p. 50.
} 
proposta pelo movimento de uma forma geral e exposta pelo médico Belisário Penna aos eugenistas:

\begin{abstract}
A linguagem deve ser simples, as expressões empregadas têm de ser as que o povo usa, e as únicas que conhece; as comparações e as imagens, vulgares e frisantes; as gravuras e fotografias, impressionantes, sem fugir á realidade de fatos, que ele conhece, mas não sabe observar; as ligações entre o seu modo de vida, o sistema de alimentação os defeitos da habitação, e as doenças, que o atacavam, acarretando-lhe serias perturbações, e a miséria, afinal, devem ser descritas com simplicidade, clareza e verdade. $^{460}$
\end{abstract}

A finalidade era conquistar também as massas populares e fazê-las compreender a importância da ciência do aprimoramento racial. A realidade serviria como fundo de pano para introdução dos ensinamentos eugênicos, pois entendiam que o aprendizado comparativo seria muito mais eficiente. Como se vê, os cuidados higiênicos e eugênicos requeriam campanhas rigorosas para que se instituíssem como uma "medida de educação, de salvação pública, de reabilitação da raça e de segurança nacional" ${ }^{\prime 61}$. Lobato correspondia como os anseios desse movimento científico ${ }^{462}$, uma vez que se utilizou de uma narrativa de fácil compreensão e de uma forma acessível de publicação (jornal), com o objetivo de recrutar as classes sociais de baixa renda em prol da limpeza social, bem como consolidar a sua imagem e suas ideias entre as camadas mais abastadas da sociedade.

Em $O$ Choque, o escritor delineia uma sociedade na qual a miscigenação é tratada como problema social e cuja solução é a esterilização dos seres disgênicos, sobretudo, dos negros. Ao argumentar sobre a primazia do sangue puro e colocar como questão as más consequências das misturas raciais, Lobato imaginava e arquitetava uma sociedade perfeita aos moldes dos eugenistas mais ortodoxos. Seu empenho em elaborar uma síntese da realidade social e traduzi-la em uma linguagem acessível, confirma o quanto ele estava afeito ao movimento eugênico.

A Revista do Brasil, da qual Monteiro Lobato foi proprietário durante o período de 1918 e 1925, foi um espaço privilegiado de discussão e fonte de grande prestígio social no

\footnotetext{
${ }^{460}$ PENNA, Belisário. Pequenos cuidados higiênicos. Revista do Brasil. São Paulo, Volume IX. Setembro Dezembro, 1918. Ano III. (n 33-36). p. 8.

${ }^{461}$ Ibidem, p. 13.

${ }^{462}$ Importante salientar que parte dos nomes dos personagens vem de inspirações de pessoas reais. Miss Astor e professor Benson se referem respectivamente a "Jean-Jacob Astor (1763-1848, mentor da Biblioteca Pública de Nova Iorque, e a um dos filhos do arcebispo de Canterbury, professor em Eton, tradicional escola inglesa". Walter Owen, ao socialista utópico inglês Robert Owen. (Cf.: AZEVEDO, Carmen L., et al. op. cit., p. 220). Já o presidente dos EUA e líder do Partido Masculino, Kerlog, tem quase que o mesmo nome do médico e higienista norte-americano John Harvey Kellogg. O nome do porta-voz da raça negra, Jim Roy, se assemelha às leis de segregação racial "Jim Crow".
} 
meio intelectual brasileiro devido ao seu posicionamento em prol do nacionalismo e das campanhas sanitarista/eugênica. Seu manifesto inaugural já denunciava sua "vontade firme de constituir um núcleo de propaganda nacionalista" 463 , pois admitia que éramos "uma nação que ainda não teve o ânimo de romper sozinha para a frente numa projeção vigorosa e fulgurante da sua personalidade", cabendo, portanto, descobrir e promover a personalidade do povo brasileiro. Contudo, esse processo deveria ser autêntico e legítimo, sem influências de estrangeirismos. Esse meio de comunicação tinha, portanto, uma missão genuinamente nacional. Desta forma, os intelectuais da Revista do Brasil promoveram o debate racial, e se apossaram da ideia de que as teorias de composição étnica eram cruciais, pois conformavam um fator decisivo "que subordinava todos os demais aspectos da vida nacional" 464.

Encontra-se nesta revista muitos artigos, resenhas, notícias e contos de renomados doutores sanitaristas e eugenistas da América Latina. Na seção Resenha do mês, por exemplo, eram transcritos textos e notícias de jornais e revistas nacionais e internacionais. O objetivo principal, como destaca Tânia R. de Luca, era debater questões da atualidade e não somente informar o leitor a respeito dos acontecimentos. Um dos temas mais abordados na primeira fase desta revista (1917 a 1925) era a questão racial atrelada ao sanitarismo e eugenismo. A heterogeneidade racial do continente americano foi motivo de especial atenção dos organizadores e diretores da Revista, o que denota como o tema era assunto de interesse da elite intelectualizada, uma vez que este veículo de informação era considerado um dos mais eruditos de sua época ${ }^{465}$.

Já em 1916, no texto A mestiçagem das raças na América ${ }^{466}$, o médico e político argentino Lucas Ayarragaray afirmava que a composição étnica de uma população era de importância "transcendente para o futuro social-político" 467 de qualquer país. Uma sociedade bem constituída era aquela derivada de uma boa prole, composta majoritariamente de tipos homogêneos da raça branca e minoritariamente de mestiços bem selecionados. Sujeito à epilepsia, “à debilidade mental, à idiotia, ao alcoolismo", o mestiço revelava "tendências

\footnotetext{
${ }^{463}$ Nota de abertura da Revista: "Revista do Brasil". Revista do Brasil. Volume I. Janeiro - abril, 1916. Ano I. (n ${ }^{\circ}$ $1-4)$, p. 1.

${ }^{464}$ DE LUCA, Tânia R. op. cit., p. 132.

${ }^{465}$ Para mais informações sobre a Revista do Brasil, conferir: DE LUCA, Tânia R. op. cit. e MARTINS, Milena R. Lobato edita Lobato: história das edições dos contos lobatianos. 2003. 418 f. Tese (doutorado) Universidade Estadual de Campinas, Instituto de Estudos da Linguagem, UNICAMP. Campinas, São Paulo, 2003.

${ }^{466}$ AYARRAGARAY, Lucas. Resenha do mês: Ciências sociais e políticas: a mestiçagem das raças na América. Revista do Brasil: São Paulo, Volume I. Janeiro - abril, 1916. Ano I. (n 1- 4). p. 349.

${ }^{467}$ Idem.
} 
criminosas e imorais"468. Sua maior deficiência, a mental, incapacitava-o de viver em civilização e, por isso, era visto como a causa principal dos problemas sociais.

Na mesma linha, a Dra. Paulina Luizi, também argentina, corroborava as proposições de Ayarragaray e de tantos outros eugenistas brasileiros. No texto A raça humana, também publicado em 1916, diz que cabe ao Estado tomar medidas "sanitárias tendentes a proteger a reprodução d[a] raça contra a degenerescência física e mental"469. Essas medidas profiláticas, em sua opinião, deviam ser limitadas aos indivíduos "atacados de enfermidades produtoras de distrofias hereditárias e degenerescências mentais" ${ }^{\text {"40 }}$. Cabia também à máquina do Estado ditar severas leis de repressão ao alcoolismo, de proibição do uso de substâncias entorpecentes, como a cocaína, o éter e a morfina, e de combate às doenças venéreas - outro fator importantíssimo e fundamental para o controle da futura prole -, como a sífilis, tão disseminada no Brasil ${ }^{471}$.

Embora esses textos sejam de doutores estrangeiros, eles dialogam com a realidade brasileira e, principalmente, com os princípios e doutrinas da eugenia na América Latina como um todo - um fenômeno estritamente "especializado com tendências conservadorasreformadoras" ${ }^{472}$. Como vimos, o Brasil foi o primeiro país latino-americano a criar uma sociedade eugênica. Na Argentina, por exemplo, somente em 1932 foi criada a Associación Argentina de Biotipologia, Eugenesia y Medicina Social que teve, diga-se de passagem, grande influência e ajuda da Sociedade Eugênica de São Paulo e de Renato Kehl ${ }^{473}$ na formatação de seus ideais. Percebe-se que a imagem de inferioridade e degenerescência do mestiço estava intrinsicamente relacionada à sua constituição física, aparentemente, debilitada. Os fatores degradantes e as condições sociais do meio no qual viviam não são colocados em debate por esses autores citados nem por tantos outros, pois era mais conveniente acreditar apenas na constituição genética e na pré-disposição à inferiorização mental dos ditos mestiços do que aceitá-los e inseri-los na sociedade exemplarmente branca e superior.

\footnotetext{
${ }^{468}$ Idem.

${ }^{469}$ LUIZI, Paulina. Resenha do mês: A raça humana. Revista do Brasil: São Paulo, Volume III. Setembro dezembro, 1916. Ano I. (n 10-13). p. 307-308.

${ }^{470}$ Idem.

${ }^{471}$ No jornal A Manhã encontramos diversas notas de publicidade de remédios e doutores que se propunham a cuidar e controlar essa doença, o que vem demonstrar como a sífilis tornara-se um problema social.

${ }^{472}$ STEPAN, Nancy Leys. A hora da Eugenia... p. 55.

${ }^{473}$ Idem, p. 62.
} 
No entanto, nos deparamos igualmente com notícias e artigos que retratavam o saneamento do Brasil como uma "reforma constitucional" ação (microbiologia; parasitologia; imunoquímica; quimioterapia; dietética; fisioterapia, eugenia $)^{475}$. Na edição de dezembro de 1918, Belisário Penna discorria sobre os Pequenos cuidados higiênicos com a finalidade de orientar os leitores quanto à necessidade urgente de uma limpeza social.

A causa primordial do atraso, da deficiência econômica, e da desorientação política do Brasil, é a decadência orgânica do seu povo, desde algumas décadas ocasionadas por doenças endêmicas evitáveis, cujos fatores são favorecidos pelo nosso clima, tão somente pela ausência de educação higiênica de governantes e governados. Por parte dos governantes tem sido notável e impressionante o descaso, e mesmo o desprezo com que, em geral, têm eles encarado os assuntos de saúde publica, e a fobia que sempre revelaram pela higiene e pelos higienistas, desprezando os seus conselhos, negando-lhes recursos para cabal desempenho dos seus encargos, criando-lhes toda sorte de embaraços, e considerando de nenhuma importância as suas funções. ${ }^{476}$

Atraso, deficiência, decadência, descaso, desprezo, entre outros, eram palavras recorrentes no vocabulário daqueles que se propunham a explicar a situação nacional brasileira através das lentes da eugenia e do sanitarismo. O texto de Penna, resultado de sua investigação pelo nordeste e centro-oeste do país, vinha comprovar as então conhecidas teorias de degeneração racial, acrescentando, contudo, a importância do saneamento básico e dos hábitos de higiene na formação constitucional e moral dos cidadãos. As doenças endêmicas, favorecidas pelo clima e descaso governamental, podiam ser evitadas por intermédio de práticas higiênicas, restaurando, assim, o brasileiro doente.

Encontramos, no mesmo ano, praticamente o mesmo manifesto sanitarista no texto de Lobato, Saneamento e higiene: as novas possibilidades das zonas cálidas. Nele o autor esclarece, novamente, os prejuízos do clima quente na composição orgânica da sociedade posto que o calor auxiliava o "desenvolvimento de vermes e doenças que aflig[iam] os homens". A higiene tinha, então, o poder de reverter ou atenuar a ação dos trópicos, pois ela era

a defesa artificial que o civilizado criou em substituição da defesa natural que perdeu. [...] Ela, só ela, permitirá criar na terra brasileira uma civilização digna deste nome. O nosso estado profundo de degenerescência física e decadência moral, provém exclusivamente disso: desaparelhamento de defesa higiênica. O nosso povo, transplante europeu feito em época de magros conhecimentos científicos, foi

\footnotetext{
${ }^{474}$ Resenha do mês: Livros e publicações. Revista do Brasil: São Paulo, Volume VII. Janeiro - Março, 1918. Ano III. (n $\left.{ }^{\circ} 26-28\right)$. p. 171.

${ }^{475}$ PEIXOTO, Afrânio. A antiga e a nova medicina: a higiene. Revista do Brasil: São Paulo, Volume VIII. Maio - Agosto, 1918. Ano III. (nº 29 - 32). p. 353-361.

476 PENNA, Belisário. Pequenos cuidados higiênicos... p. 3.
} 
invadido pela microvida tropical, e verminado intensamente, sem que nunca percebesse a extensão da mazela. Só agora se faz o diagnóstico seguro da doença, e surge uma orientação científica para a solução do problema da nossa nacionalidade, ameaçada de desbarato pelo acúmulo excessivo de males curáveis, evitáveis, e jamais curados ou evitados - porque sempre ignorados, quando não criminosamente negados. Desfeitos todos os véus de ufania, livres para sempre da mentira ditirâmbica, o caminho está desempeçado para a cruzada salvadora. Sanear o país deve ser a nossa obsessão de todos os momentos. É a grande fórmula do patriotismo que se não contenta com o jogo malabar do palavreado sonoro. ${ }^{477}$

Com o diagnóstico da doença e com as orientações científicas para "a solução do problema da nossa nacionalidade" em mãos, para Lobato, carecia ainda sanear o país num ato glorioso e patriótico. Em um período marcado pelo debate nacionalista, "aliado à percepção de que era necessário regenerar a população", a crença no sanitarismo e nas teorias de Lamarck da transmissão dos caracteres adquiridos, trazia uma aproximação com as ideias do saneamento-eugênico $^{478}$. Desta forma, o cruzamento racial passava a ser visto, por alguns estudiosos, como o responsável por todos os males da sociedade e, não obstante, passível de controle.

Na seleção humana deve-se ter, pois, como insofismável, um primeiro princípio: o afastamento sistemático das raças inferiores pela proibição severa de qualquer união entre brancos e amarelos ou negros. Para Richet a mestiçagem é um mal quase irremediável, os mestiços 'foram sempre seres medíocres e nada foi inventado por eles'. A posição dos brancos em relação aos indivíduos das outras raças é definida; 'Não se trata de martirizá-los, nem de combatê-los; não! É necessário, muito amigavelmente, muito simpaticamente, mantê-los á distância. Eis tudo"". 479

De acordo com o médico Miguel Osório de Almeida, a mistura racial deveria ser abolida, pois ela era o motivo do "mal quase irremediável" e formadora de seres medíocres e inferiores. Assim, dizia caber aos brancos, "amigavelmente" e "simpaticamente", manter a distância desses tipos degenerados e não constituir com eles laços matrimoniais. Esse e tantos outros textos, além de compartilharem o mesmo teor, demonstram como a elite intelectualizada temia o "outro", especificamente o negro e o mestiço. Expressam ainda como uma parte desse grupo se propôs a denunciar as mazelas causadas por esse "incidente" social, e como o tema era discutido no âmbito público (embora restrito à camada letrada). Além do mais, evidenciam como Monteiro Lobato estava sendo informado sobre os debates científicos raciais daquele período.

\footnotetext{
${ }^{477}$ LOBATO, M. Saneamento e higiene: as novas possibilidades das zonas cálidas. Revista do Brasil: São Paulo, Volume VIII. Maio - Agosto, 1918. Ano III. (n 29 - 32). p. 3 - 8.

${ }^{478}$ HABIB, Paula A. B. B. Saneamento, Eugenia e Literatura: os caminhos cruzados de Renato Kehl e Monteiro Lobato (1914-1926). XXIV Simpósio Nacional de História - ANPUH, 2007. p. 2.

${ }^{479}$ Grifos nossos. ALMEIDA, Miguel Osório de. A seleção humana. Revista do Brasil: São Paulo, Volume XV, Setembro - Dezembro, 1920. Ano V. $\left(n^{\circ} 57\right.$ - 60). p. 5
} 
Preocupados com as dificuldades e necessidades de se arquitetar uma nação, os eugenistas ao mesmo tempo em que tentavam explicar o país, buscavam transformá-lo. Isso significa que, a partir de então, cada um, ao seu modo, começava a imaginar uma nação nos moldes da ciência. $\mathrm{O}$ modo de definir, projetar e imaginar a pátria por eles estava diretamente relacionado à ideia de uma sociedade geneticamente saudável, ariana e economicamente estável. Por isso, condenavam a composição racial heterogênea, uma vez que estudos comprovavam a estreita relação entre fracasso social e mistura racial.

Mais do que preservar os caracteres superiores e controlar os disgênicos, era necessário também dar a devida atenção a outro grande problema que se apresentava: o político. Renato Kehl e alguns eugenistas acreditavam que somente eles, autoproclamados "evangelistas da harmonia social" ${ }^{480}$, conseguiriam colocar ordem na miscelânea de problemas sociais, econômicos, raciais e genéticos que assolavam o Brasil porque possuíam um raciocínio científico realmente capaz de tratar as questões coletivas. Assim sendo, eram os mais capacitados para conjecturar a sociedade em toda a sua complexidade e para implementar políticas públicas que atendesse a nação em toda a sua abrangência. Consideravam-se os mais preparados para dirigir a nação e acreditavam que a implementação de políticas públicas de caráter eugênico, tais como na área da educação, medicina, segurança e controle social, eram as mais apropriadas para conduzir o país na busca do bem em comum $^{481}$. Nesse sentido, afirmavam que as ideias pregadas pela eugenia só encontrariam terreno fértilonde reinasse a saúde e convivessem indivíduos superiores. Cumpria "pois, sanear fisicamente para em seguida fazer o saneamento político"482.

Constatados o peso histórico da miscigenação, bradavam a urgência de uma reforma social. A ciência dos bem nascidos ganhava importância e espaço na medida em que parte das elites intelectuais preconizava a importância da articulação entre ciência e interpretação social. Essa elite entendia que, para a composição de uma sociedade perfeita, era imprescindível atrelar a questão de hereditariedade com a questão racial ${ }^{483}$, bem como dar destaque às questões nacionalista. O médico-sanitarista Belisário Penna, atribuía aos negros à degradação moral e física dos mestiços porque, "relegados a coisa de abaixo dos animais,

\footnotetext{
${ }^{480}$ KEHL, Renato. Eugenia e medicina social (problemas da vida)... p. 18.

${ }^{481}$ Idem.

482 Idem.

483 SCHWARCZ, L. M. Espetáculo da Miscigenação. Estudos Avançados. 8(20), Universidade de São Paulo, 1994. 147p. p. 138
} 
espalharam-se por toda parte" ${ }^{484}$, não só contraíram doenças das quais não se protegeram, mas também constituíram-se o próprio foco de propagação.

Foi sobretudo a partir da data em que demos ao negro a liberdade de adoecer, sem se tratar; de se alcoolizar, sem corretivo; de conviver com os barbeiros e os mosquitos, sem sombra de assistência; de levar a vida de judeu errante, a poluir por toda a parte as terras e as aguas, à vontade, que as doenças se intensificaram, se alastraram e se tornaram endêmica. ${ }^{485}$

De acordo com Penna, a liberdade sem supervisão relegada aos homens de cor acarretou na proliferação de focos de enfermidades e epidemias que devastavam a sociedade mestiça e pobre. A doença de Chagas, o tifo, a esquistossomose, a sífilis, a varíola e o alcoolismo eram algumas das doenças que aniquilaram grande parte da população brasileira e que foram responsáveis pela criação de alguns mitos sociais, como a preguiça e a delinquência dos caboclos. Os negros, para esse médico, "contaminaram toda a população, vingando-se assim inconscientemente dos brancos" ${ }^{486}$. Como pode-se ver, a culpa era sempre do "outro" (negro) e jamais do branco. Aquele sempre atrapalhara, mesmo que despropositadamente, o progresso deste e, consequentemente, da nação em geral. Os adeptos do pensamento de Belisário Penna, bem como de Renato Kehl, disseminavam a ideia de que não éramos um país desenvolvido social e economicamente igual às demais sociedades europeias porque fatores como o clima e a mistura racial haviam produzido uma "população preguiçosa, indisciplinada e pouco inteligente" ${ }^{, 487}$. A inferioridade biológica era, portanto, o principal motivo da "inadaptabilidade à sociedade moderna e industrial"488 deste povo.

Muitas dessas teorias sanitaristas e eugênicas apresentadas na Revista do Brasil ${ }^{489}$ podem ser encontradas nas falas das personagens de Lobato. Acreditamos que a aquisição desse periódico oportunizou um espaço de experiência de real importância na vida do escritor, principalmente, porque ele sofreu diretamente as influências de tudo aquilo que foi publicado. Todavia, questionamos se as suas afinidades científicas e intelectuais foram preponderantes nas escolhas dos textos ali divulgados, ou se foram os próprios artigos que lhe introduziram nessa jornada científica, agregando-lhe novos conhecimentos. Acreditamos que tanto a simpatia de Lobato por algumas matérias, como a publicação de textos aparentemente

\footnotetext{
${ }^{484}$ PENNA, Belisário. Pequenos cuidados higiênicos... p. 5.

${ }^{485}$ Idem, p. 6.

486 Ibidem, p. 5.

${ }^{487}$ SANTOS, Ricardo Augusto dos. Eugenia, Saneamento e Educação... p. 4.

488 Idem.

${ }^{489}$ Nas edições do ano de 1919 foram publicadas pequenas biografias sobre Afrânio Peixoto, Oliveira Vianna e Belisário Penna, todos representantes do movimento sanitarista, nas quais são apresentados como grandes homens símbolo da ciência, do progresso e futuro da nação.
} 
desconhecidos na Revista, induziram a formação do pensamento racial deste autor. Se a finalidade deste periódico era construir um sentimento de nacionalidade e criar ícones que a representasse, Lobato certamente encarregava-se de selecionar tudo o que seria publicado.

Visto que a intenção em doutrinar o público não era algo exclusivo de Monteiro Lobato e que suas ações eram, recorrentes entre os adeptos do movimento eugênico, vamos agora entender como o literato se apropriou desses conhecimentos e transformou-os em narrativa literária. O objetivo será desvendar o enigma final do romance, o beijo entre a bela Miss Jane e o então doutrinado Ayrton Lobo.

\section{"A escola não faz o homem"490}

Para a eugenia, as mulheres tinham um papel primordial no processo de fortalecimento da raça e, por isso, eram denominadas de "Sacerdotisas da Eugenia",491. A reprodução, segundo Nancy Stepan, "definia o papel social das mulheres" 492 porque elas eram mais "vulneráveis e socialmente dependentes do que os homens" 493 . Essa circunstancia "fazia com que a administração de suas vidas reprodutivo-hereditárias parecesse mais urgente e mais factível" ${ }^{\text {"494 }}$. Nesse sentido, a procriação era responsável pela modificação e transmissão dos fatores hereditários, por isso os eugenistas acreditavam que o êxito das futuras gerações recaía diretamente sobre a figura da mulher. Sua função social estava relacionada, portanto, à concepção e educação dos seus herdeiros. Não bastava carregar durante nove meses o seu rebento, à mãe cabia todos cuidados e ensinamentos dos primeiros anos de formação da criança ${ }^{495}$. "Educadora do lar" ${ }^{496}$, cabia a ela tarefas diárias, como educar, alimentar, vigiar e

\footnotetext{
${ }^{490}$ KEHL, Renato. Bio-Perspectivas... p. 60.

491 OLIVEIRA, William Vaz de. Intolerância étnica e racial: o pensamento eugenista no Brasil e o ideal de "purificação" das raças. Cadernos de Pesquisas do CDHIS, n. 36/37, ano 20, p. 75-82, 2007. p. 79. Disponível em: <http://www.seer.ufu.br/index.php/cdhis/article/viewFile/1219/1163> Acesso em agosto 2014.

${ }^{492}$ STEPAN, Nancy Leys. A hora da Eugenia... p. 116.

${ }^{493}$ Idem.

${ }^{494}$ Idem.

${ }^{495} \mathrm{O}$ aleitamento fazia parte do processo de fortalecimento da prole eugenicamente perfeita, no entanto, não era o único meio que merecia especial atenção. Kehl afirmava que: "A amamentação, o aleitamento artificial, tudo o mais é muito e muito importante porém, a condição principal, repetimos, é a criança ser um produto da conjugação de boas taras ou melhor, de bons pro-núcleos, ou mais simplesmente, ser gerada de Pais fortes e sadios.” (Cf. KEHL, Renato. Eugenia e medicina social (problemas da vida)... p. 111)

${ }^{496}$ HABIB, Paula A. B. B. Eis o Mundo Encantado que Monteiro Lobato Criou... p. 159.
} 
medicar, pois a saúde da família e da raça dependeria do desempenho dessas atividades ${ }^{497}$, então sobrepujada pelo movimento feminista.

Para tanto, Renato Kehl declarava ser necessária a existência de leis que protegessem as mulheres: "pois para elas o trabalho extenuante além de ser desumano representa um terrível fator de degeneração" ${ }^{, 498}$. Se a progenitora estivesse doente, certamente sua prole também herdaria seus males. Isto posto, numa sociedade patriarcal, incumbia-se às mulheres a missão do lar: procriar, criar e educar bons filhos. Assim sendo, ela era "biologicamente mais valiosa que o homem na conservação da espécie"499.

Acima da mulher estava a família, unidade social básica e relevante na luta em prol de uma sociedade eugenicamente perfeita. Aos homens também competiam determinado esforço em prol da linhagem, pois eles seriam encarregados de supervisionar as atitudes de seus filhos, a fim de evitar um comportamento desregrado e mórbido, tão presente nas raças inferiores. Logo, "homem e mulher seriam o complemento ideal para a regeneração da espécie; ela a força ativa, ele a força potencial ${ }^{\circledR 500}$. O casamento, desta forma, era visto como um fator crucial que poderia levar tanto ao sucesso como ao fracasso da ciência do dia. A escolha do cônjuge determinava a qualidade da prole do casal. De nada adiantava apenas um indivíduo possuir bons caracteres se o outro era degenerado e doente. Fazia-se necessário o controle as comunhões para que as novas gerações viessem ao mundo realmente saudáveis.

Em virtude disso, o casamento ganhou especial atenção para os eugenistas. Várias foram as discussões acerca da normatização dos matrimônios e produção de projetos de leis como a que propunha o certificado pré-nupcial, apresentado à Câmara dos Deputados na década de 1920. A intervenção direta nas uniões conjugais refletia o desejo em controlar a a "qualidade" dos recém-nascidos do país (já praticado em outros países, como os EUA). Pregava-se a racionalização da reprodução, assim, os "casais fortes" seriam estimulados a terem um maior número de filhos, haja vista a preservação das qualidades superiores da "raça ariana" ${ }^{, 01}$. Miss Jane, no capítulo XIX (Burrada), ao contar o episódio ocorrido nos EUA em

\footnotetext{
${ }^{497}$ De acordo com Renato Kehl, "Até os dez primeiros anos de idade, as crianças vivem quase exclusivamente sob as vistas maternais, portanto, às mães cabe uma enorme responsabilidade nos óbitos, que se dão nessa primeira fase da vida". Cf.: KEHL, Renato. Eugenia e medicina social (problemas da vida)... p. 68.

${ }^{498}$ Ibidem, p. 194.

${ }^{499}$ CARVALHO, Arnaldo V. de. Resenha do mês: A biologia e a mulher. Revista do Brasil: São Paulo, Volume VII. Janeiro - Março, 1918. Ano III (nº 26-28), p. 296.

${ }^{500}$ HABIB, Paula A. B. B. Eis o Mundo Encantado que Monteiro Lobato Criou... p. 159.

${ }^{501}$ SOUZA, Vanderlei Sebastião de. A Eugenia no Brasil: ciência e pensamento social no movimento eugenista brasileiro do entre-guerras... p. 4.
} 
2228, faz Ayrton perceber a "burrice" cometida pelo governo brasileiro de não colocar em prática o código de controle de natalidade:

\begin{abstract}
- Mas realmente parece incrível, Miss Jane [...], que ainda hoje tenha o direito de ser pai quem quer! Morféticos há ali na roça que botam no mundo anualmente pequeninos lázaros. E ninguém vê, ninguém diz nada, todos acham que está tudo direito...

Eu sentia-me a ferver, com ímpetos de pular para a rua e berrar para todos os ventos: - Burrada!...

Miss Jane acalmou-me a fúria e prosseguiu:

- E não parava aí a intervenção seletiva. Se um 'pai autorizado' pretendia casar-se, tinha de apresentar-se com a noiva a um Gabinete Eugenométrico, onde lhes avaliavam o índice eugênico e lhes estudavam os problemas relativos à harmonização somática e psíquica. Caso um deles não atingisse o índice exigido, poderiam contrair núpcias, mas sob a condição de infecundidade. ${ }^{502}$
\end{abstract}

A administração das relações conjugais apresentada por Miss Jane também era um dos tão almejados projetos dos eugenistas, pois enxergavam no controle reprodutivo dos disgênicos e no incentivo da procriação dos "bem dotados" uma forma de atingir o aprimoramento racial. Para Galton, eram necessárias mudanças rápidas e concretas nesse meio, e chegou a sugerir a criação de um "sistema de registro de casamentos" integrado "a um projeto de saúde em que as partes contratantes chegariam a um certo padrão de higiene exigido" ${ }^{204}$. Seguindo as doutrinas do pai da eugenia, Renato Kehl, preconizava uma "política biológica nacional", cujas medidas deveriam ser:

1) registro de pedigree das famílias; 2) segregação dos deficientes criminais; 3 ) esterilização dos anormais e criminosos; 4) neo-malthusianismo com os processos artificiais para evitar a concepção nos casos especiais de doença e miséria (controle do nascimento); 5) regulamentação eugênica obrigatória nas escolas secundárias e superiores; 7) propaganda popular de preceitos e conceitos eugênicos; 8) luta contra os fatores disgenizantes por iniciativa privada e pelas organizações oficiais; 9) testes mentais das crianças entre 8 e 14 anos; 10) regulamentação dos filhos ilegítimos; 11) estabelecimento de cuidados pré-natais das gestantes e pensões para as mulheres pobres; 12) regulamentação da imigração sobre a base da superioridade médio dos habitantes do país, estabelecidos por testes mentais; 13) estabelecimento dos defeitos hereditários disgênicos que impedem o matrimônio e os que podem servir de base à pleitação [sic] do divórcio. ${ }^{505}$

Essas propostas tinham como fim a formação de uma sociedade eugenicamente perfeita. Apesar de não terem encontrado terreno fértil para se desenvolver na sociedade brasileira, esses preceitos tiveram certo impacto, tanto que na Constituição Brasileira de

\footnotetext{
${ }^{502}$ LOBATO, M. O choque das raças. A Manhã: Rio de Janeiro, 19 de setembro 1926, ano II, n. 227 , p. 4.

${ }^{503}$ ROCHA, Simone. A educação como ideal eugênico: o movimento eugenista e o discurso educacional no boletim de eugenia 1929-1933. Cadernos de pesquisa, v. 6, n. 13, 2011. p. 116.

${ }^{504}$ Idem.

${ }^{505}$ KEHL apud SOUZA, Vanderlei Sebastião de. A “eugenia negativa” nos trópicos... p. 6.
} 
$1934^{506}$ foi inserida a proposta dos eugenistas de tornar responsabilidade do Estado a promoção da educação eugênica. Outro sucesso, apontado por Nancy Stepan ${ }^{507}$, foi a introdução da "cláusula nubente", a qual exigia dos casais nubentes um atestado de saúde física e mental para que contraíssem o matrimônio. Apesar de suas limitações, a legislação pré-nupcial demonstra o lugar privilegiado que a ciência e a eugenia ocupavam no discurso político e social do país.

O exame pré-nupcial era obrigatório, mas a lei foi qualificada por declarações de que sua aplicação levaria em consideração as condições regionais do país (um reconhecimento da ausência de qualquer aparato administrativo que pudesse supervisionar a aplicação da lei e, de fato, a ausência de números adequados de autoridades de saúde em qualquer outra parte que não as grandes cidades). ${ }^{508}$

Homens e mulheres deviam ser submetidos aos exames pré-nupciais para comprovar ao Estado que não eram disgênicos e para garantir à sociedade a constituição de famílias salutares. Porém, o passado patriarcal ainda refletia sobre as mulheres, incumbindo-lhes as grandes responsabilidades da reprodução e criação dos tipos perfeitos. Nancy Stepan nos alerta para estudos historiográficos que enfatizam algumas características reformadoras, sugerindo uma eugenia de força progressista e, às vezes, "protofeminista", onde a mulher tem total autonomia para desempenhar seu papel social sem as amarras da figura masculina. Com a inserção da mulher no mercado de trabalho e a ascensão do feminismo, algumas mulheres, de acordo com esses estudos, encontravam nas sociedades eugênicas um novo espaço para ação social, desempenhando papéis na defesa do controle de natalidade, e no registro e tratamento das doenças venéreas, por exemplo. No Brasil, o movimento feminista

foi domesticado e até banalizado: a 'ubíqua influência da Igreja Católica Romana (...) ajudou a manter o movimento feminista dentro de limites aceitáveis, evitando as tentativas feministas de vincular a opressão das mulheres à maternidade, à família ou à religião. ${ }^{509}$

\footnotetext{
${ }^{506}$ O Artigo 138 incumbia à União e aos Estados o amparo aos "desvalidos", bem como: "a) assegurar amparo aos desvalidos, criando serviços especializados e animando os serviços sociais, cuja orientação procurarão coordenar; b) estimular a educação eugênica; c) amparar a maternidade e a infância; d) socorrer as famílias de prole numerosa; e) proteger a juventude contra toda exploração, bem como contra o abandono físico, moral e intelectual; f) adotar medidas legislativas e administrativas tendentes a restringir a moralidade e a morbidade infantis; e de higiene social, que impeçam a propagação das doenças transmissíveis; g) cuidar da higiene mental e incentivar a luta contra os venenos sociais". Cf.: Constituição da República dos Estados Unidos do Brasil (de 16 de julho de 1934). Disponível em: <http://www.planalto.gov.br/ccivil_03/Constituicao/Constituicao34.htm>. Acesso em outubro de 2014. Observe que, embora apenas a alínea "b" mencione de forma direta a eugenia, todos os demais abordam medidas profiláticas eugênicas.

${ }^{507}$ STEPAN, Nancy Leys. A hora da Eugenia... p. 135.

${ }^{508}$ Idem.

${ }^{509}$ Ibidem, p. 123.
} 
Essas assertivas nos permitem diversas considerações acerca da não proeminência da voz feminina nas sociedades e comissões eugênicas brasileiras. Infelizmente, essa discussão é mais profunda e complexa, e extrapola os limites dessa dissertação. Conclui-se, portanto, que a postura das mulheres apresentadas em $O$ Choque, ainda que deixem alguns rastros incompreensíveis, são reflexo de um debate caloroso sobre a imagem feminina e o seu lugar na sociedade. Lobato posicionou-se contrário ao movimento feminista por acreditar que ele tirava o melhor das mulheres, o seu apreço e cuidado à família, concedendo-lhes um caráter masculinizado fora dos padrões atribuídos à mulher.

A história de ódio e amor entre homens e mulheres retratada no romance, bem como as três imagens femininas construídas por Lobato - Miss Jane, Miss Elvin e Miss Astor -, nos oferecem bom material para a reflexão sobre o status da mulher na sociedade brasileira do início do século XX e para a compreensão da visão do autor sobre o tema. Ainda mais, representam a proposta final, totalmente amparada na convicção dos bons casamentos como fruto do aprimoramento social. Consciente da incongruência de se pensar a esterilização dos negros e mestiços para o Brasil, Lobato utiliza-se do beijo final como subterfúgio para demonstrar enfim sua solução para o problema racial. Dessa maneira, Miss Jane, a encarnação da eugenia, coloca em prática um determinado tipo de seleção. Ela não se entrega em um ato de amor e paixão, mas, sim, de forma racional e eugênica, pois percebera que Ayrton não era tipo qualquer como havia suposto no início da história. Ele era um tipo miscigenado superior, possível de ser esposado sem trazer danos à prole e à nação.

Ao unir Miss Jane, a "filha da raça mais nobre do mundo, oriunda do sangue mais puro" 510 e Ayrton Lobo, "homem comum" e, provavelmente, mestiço ${ }^{511}$, Monteiro Lobato propõe uma intervenção seletiva eugênica. Benson e sua filha desde o início da história selecionavam o seu futuro marido. Num ato desprovido de paixão, Miss Jane se enlaça ao tipo "melhorado" e selecionado. Se observarmos bem, veremos que esse desfecho longe de ser romântico foi essencialmente eugênico, uma resposta favorável à miscigenação como forma

\footnotetext{
${ }^{510}$ LOBATO, M. O choque das raças. A Manhã: Rio de Janeiro, 9 de setembro 1926, ano II, n. 218, p. 5.

511 Esse personagem é apresentado inicialmente como um "homem comum", sem estudos, trabalhador que recebia "o necessário para pagar o quarto onde morava, a pensão onde comia e a roupa que vestia" e "curado de jogatinas". Embora possuísse um automóvel, diz ter trabalhado por quatro anos para conseguir comprá-lo. Essas características, levando-se em conta a predominância mestiça da sociedade e o teor eugenista do romance, nos levam a pensar ser ele um mestiço pobre, porque os brancos, seres superiores, não estariam envolvidos, por exemplo, em jogatinas, traço típico de homens e mulheres degenerados. Mas é, sobretudo, a ausência de informação de suas características físicas que mais chamam atenção. Enquanto Miss Jane é descrita fisicamente como branca, loira e de olhos azuis, Ayrton Lobo não é descrito fenotipicamente, ou seja, somente suas características psicológicas são apresentadas pelo autor, sugerindo uma "impureza” racial.

Cf.: LOBATO, M. O choque das raças. A Manhã: Rio de Janeiro, 5 de setembro 1926, ano II, n. 215 , p. 1 e 5.
} 
de se chegar ao aprimoramento racial. Embora pareça contraditória essa afirmação, o literato, mais uma vez, estava a reproduzir um debate polêmico de sua época. A miscigenação era pensada e entendida de formas diferentes. Entre os eugenistas havia dois posicionamentos distintos: um favorável, outro contrário. Renato Kehl era um dos que assumiam seu posicionamento veementemente avesso à hibridização, pois acreditava que ela conferia ao Brasil um caráter instável e crítico.

Dado pouco tempo decorrido da colonização do Brasil, e do caldeamento de tantos sangues diferentes, é natural que ainda não exista uma raça brasileira, porque a mistura étnica, até agora processada, ainda não apresenta homogênea, estável, não tem feição característica e original. Essa química racial levará ainda muitos séculos para apresentar um padrão nacional, dotado de caracteres próprios, sólidos, sem arestas que denunciem a heterogênea cristalização. ${ }^{512}$

Embora o português fosse considerado um desbravador astuto e de raça forte ${ }^{513}$, avaliava que o seu cruzamento com negros africanos e indígenas havia produzido uma miscelânea racial cujas características, no final das contas, não representavam nenhuma dessas raças. A falta de uma identidade fez com que muitos julgassem que éramos um país sem nação e, logo, sem nacionalidade, sem cidadãos ${ }^{514}$. Por outro lado, tendo em vista que o cruzamento racial era um dado irremediável na composição da sociedade brasileira, alguns intelectuais adaptaram-se aos conhecimentos científicos da eugenia com o propósito de "salvar" a nação. Ora, se a população era constituída em sua maioria de negros e mestiços, era necessário que se instituíssem métodos de contenção/seleção e não de extermínio. Esse posicionamento "mais brando" foi visto como factível pelos países da América Latina, tendo em conta a constituição mesclada de suas populações ${ }^{515}$.

Assim, havia aqueles que conseguiam enxergar pontos positivos na mistura racial e identificar os diferentes tipos de mestiço que eram gerados. Nina Rodrigues (em 1922), por exemplo, acreditava que dentre os indivíduos miscigenados havia os superiores, os degenerados e os comuns.

Entendo que se podem distribuir os mestiços por três grupos distintos. Primeiro, o dos mestiços superiores, que pela dominância da raça civilizada na sua organização hereditária, ou por uma combinação mental feliz, de acordo com a escola clássica, devem ser julgados perfeitamente equilibrados e plenamente responsáveis. Segundo, os mestiços evidentemente degenerados... tristes representantes de variedades

\footnotetext{
${ }^{512}$ KEHL, Renato apud HABIB, Paula A. B. B. Mundo Encantado que Monteiro Lobato Criou... p. 102.

${ }^{513}$ Idem.

514 A frase de Alberto Torres, de 1902, ainda ecoava nas mentes brasileiras: “... este Estado não é uma nacionalidade, este país não é uma sociedade, esta gente não é um povo. Nossos homens não são cidadãos”. (Cf.: TORRES apud LUCA, T. R. op. cit., p. 34)

${ }^{515}$ STEPAN, Nancy Leys. A hora da Eugenia... p. 189.
} 
doentias da espécie... Dentre eles, uns devem ser total, outros parcialmente irresponsáveis. Terceiro, finalmente os mestiços comuns, produtos socialmente aproveitáveis, superiores às raças selvagens de que provieram, mas que, já pelas qualidades herdada dessas raças, já pelo desequilíbrio mental que neles operou o cruzamento, não são equiparáveis à raças superiores e acham-se em iminência constante de cometer ações anti-sociais de que não podem ser plenamente responsáveis. ${ }^{516}$

Se, para alguns, a miscigenação foi vista como repugnante e execrável, para outros, foi entendida como um meio exequível de aperfeiçoamento racial. Se o erro inicial já havia sido cometido, não adiantava se lamentar. Cumpria, pois, entender os males e benefícios da mistura racial e trabalhar com a realidade. Nina Rodrigues classificava os mestiços em três categorias hierárquicas. A partir desse olhar, acreditava que era possível entender o nível de responsabilidade e consciência de cada um, para assim criar legislações distintas e particulares.

No entanto, essa interpretação de gradação do nível intelectual entre os mestiços apoiava-se nos fundamentos positivistas da eugenia. Ou seja, o cruzamento entre brancos e negros tinha a tendência de revelar uma prole mais sadia e bela ${ }^{517}$ do que a da raça negra. De acordo com a lei de superioridade racial, o sangue branco sobrepujaria o negro, criando, assim, um mestiço menos degenerado e superior aos outros. Esse pensamento otimista previa que a nossa população seria cada vez mais branca. Oliveira Lima caracterizava o negro como inferior, "mas passível de redenção - sob a tutela dos brancos e através da miscigenação"

Fica evidente, assim, que o enlace das duas personagens de $O$ Choque das Raças foi uma escolha premeditada, uma seleção meticulosamente realizada segundo os preceitos mais avançados da ciência eugênica, por Miss Jane, o tipo de mulher exemplar da eugenia. Segundo essa ciência, para casamentos prósperos, era necessário deixar o amor, "cego e irrefletido" ${ }^{519}$, de lado e pensar nos princípios sociais que o matrimônio exigiria ${ }^{520}$. Logo, ao observar que o rapaz aprendia rápido e se convencia dos preceitos eugênicos, Jane conseguiu vislumbrar nele um bom futuro, pois ele seria um bom reprodutor. Apesar de não ter sangue puro e ser pobre, Ayrton Lobo demonstrava outras habilidades. Sua capacidade intelectual o revelava um mestiço superior.

A escola não faz o homem; revela-o ou não. Ninguém pode esperar grande luz de uma simples lamparina, mesmo quando transborde de azeite. Cada indivíduo brilha

\footnotetext{
${ }^{516}$ RODRIGUES, N. apud LUCA, T. R. op. cit., p. 169-170.

${ }^{517}$ Idem.

${ }^{518}$ SKIDMORE, T. E. op. cit., p. 120.

${ }^{519}$ KEHL, Renato. Eugenia e medicina social (problemas da vida)... p. 68.

${ }^{520}$ Idem.
} 
conforme o seu fiat-cerebral; cada um tem o senso que lhe é peculiar, isto é, adequando á sua sindéreses ${ }^{521}$.

Renato Kehl acreditava que embora a educação fosse primordial no processo de eugenização da população, ela não seria capaz de regenerar os degenerados. Os esforços educativos não eram suficientes para extinguir "os vestígios de barbaridade da raça nem as causas da degeneração humana" ${ }^{, 522}$. Como o país era mestiço, o ensino conseguiria despertar e revelar a natureza superior de alguns, mas não saneá-lo. Assim, a educação teria a função de revelar as virtudes de cada indivíduo. Com isso, acreditamos que da mesma forma que Miss Jane testa e doutrina Ayrton até descobrir suas qualidades, Lobato faz o mesmo com o seu leitor. Se ao final do romance o caro leitor não estivesse convencido dos benefícios e da eficácia da eugenia, provável seria que ele não possuísse a virtude da inteligência.

Apesar de contestar inicialmente algumas ideias apresentadas por Miss Jane, do meio da narrativa para o final, Ayrton começa a ouvir atentamente os relatos, e, maravilhado, passa a concordar com tudo e a apreciar os efeitos dessa "tal profilaxia" ${ }^{523}$. Bem doutrinado, começava a enxergar como "Burrada!" 524 o desamparo do governo com a reprodução social: “- Como era claro e inteligente" ${ }^{252}$, dizia o mais novo seguidor da eugenia referindo-se à reprodução assistida. A união dessas personagens demonstra que Lobato tinha convicção na “miscigenação assistida”. Foi Miss Jane que escolheu seu parceiro e não o contrário. O seu distanciamento e indiferença demonstram que sua decisão foi racional e eugênica. Não esperou se apaixonar por Ayrton, mas, sim, descobrir as suas virtudes. Contudo, o beijo final, aparentemente simples, ganha outras conotações quando passamos a entender o título do capítulo derradeiro.

O capítulo XXV, denominado $O$ Beijo de Barrymore, tinha todo um sentido de ser para a geração de leitores de 1926. À época, estava em cartaz o filme norte-americano A fera do mar no qual John Barrymore ${ }^{526}$, um "rude marinheiro", "volta à sua terra e no primeiro encontro com a noiva aproa-lhe o coração com um beijo inédito no mundo"527. O estrondo em torno do enérgico beijo fez com que o filme fosse censurado na cidade de São Paulo. A película abalou as plateias por onde passou e gerou descontentamento naqueles que não

${ }^{521}$ KEHL, Renato. Bio-Perspectivas... p. 60.

${ }^{522}$ Idem.

${ }^{523}$ LOBATO, M. O choque das raças. A Manhã: Rio de Janeiro, 23 de setembro 1926, ano II, n. 230 , p. 5.

${ }^{524}$ Idem.

525 Idem.

${ }^{526}$ Um dos artistas norte-americanos mais famosos daquele período.

${ }^{527}$ LOBATO, M. O beijo que S. Paulo não viu. A Manhã: Rio de Janeiro, 4 de setembro de 1926, ano II, n. 214 , p. 3 . 
tiveram a oportunidade de assistir. Inconformado com a censura, Monteiro Lobato escreveu na $A$ Manhã uma nota ${ }^{528}$ de desgosto dizendo que o beijo que fez "fremir o mundo, S. Paulo não o conheceu. Há lá uma coisa chamada censura que se arroga o direito de mutilar obras d'arte mundiais" ${ }^{, 529}$. O beijo de Barrymore apagava da memória todos os beijos até então “dados, vistos, sabidos, lidos e sonhados" ${ }^{\text {530 }}$. Foi, segundo o escritor, o beijo mais badalado de 1926.

Talvez por isso nomeou o último capítulo de $O$ Beijo de Barrymore, pois o nome trazia a imagem de uma cena de amor inquietante e curiosa. Além disso, sugere que o beijo entre Miss Jane e Ayrton Lobo foi cinematográfico e arrebatador. Assim, travestido de um apaixonante enlace, o enigmático beijo final apresentava-se também como eugênico. $\mathrm{O}$ que corrobora as sugestões de Kehl de que a mulher poderia, bem como deveria, escolher melhor com quem se casar $^{531}$. Se a natureza demoraria a impor-se, cabia aos homens e mulheres acelerar todo o processo que um dia seria natural. Deste modo, Jane faz uma intervenção seletiva ao escolher Lobo como companheiro.

Essa assertiva se sustenta porque, segundo Quaglino, certa vez Lobato confirmou ter sido Oliveira Vianna "um dos seus gurus nos assuntos de raça quando aplicados ao "caso brasileiro" ${ }^{, 532}$. Este intelectual eugenista dizia que os prognósticos catastróficos de Gobineau e Le Bon, por exemplo, não se aplicam por aqui porque eles não tinham considerado os "cruzamentos felizes" brancos para gerar mestiços superiores. Assim, “os processos de seleção social e degeneração racial se encarregariam de eliminar os negros e mestiços inferiores" ${ }^{~} 534$. Unindo a eugenia positiva e preventiva à negativa, restaurava-se o homem brasileiro.

Enquanto a vertente positiva via a miscigenação como um meio eficaz para o branqueamento da sociedade e como um prenúncio de um amanhã promissor, a corrente negativa entendia que a mistura racial havia condenado o homem e criado um horizonte de incertezas. Lobato, ao filiar-se ao grupo otimista, demonstrava com a sua máquina do tempo que era possível enxergar um porvir melhor se houvesse controle e medidas eugênicas. Deste

\footnotetext{
${ }^{528}$ Idem.

${ }^{529}$ Idem.

${ }^{530}$ Idem.

${ }^{531}$ KEHL, Renato. Eugenia e medicina social (problemas da vida)... p. 68.

${ }^{532}$ QUAGLINO, Maria Ana. Noções de Raça e Eugenia em Monteiro Lobato: vida e obra..., p. 8.

${ }^{533}$ Idem.

${ }^{534}$ Idem.
} 
modo, apresentava a face obscura de um futuro marcado pelo choque das raças e lançava luzes sobre o presente, cuja esperança estava na seleção do casamento entre indivíduos superiores. Nos EUA de $O$ Choque, o livre desenvolvimento da raça negra foi responsável pelo seu triste fim, o extermínio dos negros por meio da esterilização.

O desfecho do drama racial da América comoveu-me profundamente. Não ter futuro, acabar... Que sensação torturante não seria a dessa massa de cem milhões de criaturas assim amputadas do seu porvir! Em compensação, que maravilhoso surto não ia ter na América o homem branco, a expandir-se sem o menor empeço na sua Chanana prodigiosa. ${ }^{535}$

A esterilização é vista por Ayrton como uma catástrofe porque impedira o desenvolvimento de uma raça, e o consequente aperfeiçoamento de suas futuras gerações. No entanto, a questão do sangue sobrepunha-se à questão de justiça, o que acabava por amenizar as ações extremistas da eugenia. Embora comovido, o personagem sabia que essa havia sido a melhor saída para o impasse, pois o branco agora podia "expandir-se sem o menor empeço", ou seja, sem o menor empecilho ou prejuízo. De forma indireta, acreditamos que o objetivo de Lobato era demonstrar que embora nos EUA não houvesse misturas entre brancos e negros, houve, tempos depois, um choque entre ambos. Desta forma, cabia ao Brasil do presente (1926) colocar em prática a eugenia e a miscigenação supervisionada a fim de construir uma sociedade mais branca e próspera no futuro. portanto, o seu foco estava no Brasil e não nos Estados Unidos, posto que a solução de lá já estava clara e definida.

Além da educação como instrumento eugênico, Lobato acreditava que também seria necessário o fomento governamental de ondas imigratórias de indivíduos superiores, de "homens mais sábios para civilizar o Brasil", reproduzindo o mesmo discurso dos eugenistas. O incentivo à imigração europeia foi, especialmente na década de 1920, um dos recursos utilizados pelos governantes brasileiros para solucionar o problema de mão de obra assalariada e o incômodo social causado pela miscigenação. Trazer homens e mulheres racialmente superiores e civilizados parecia ser o remédio. Aos poucos, os eugenistas foram percebendo que o simples incentivo à imigração sem uma seleção prévia dos imigrantes seria uma solução ineficaz. Necessário se fazia restringir a entrada dos estrangeiros inferiores e degenerados. Essa tentativa de manobra político-social gerou muita polêmica.

Os anais do $1^{\circ}$ Congresso Brasileiro de Eugenia, em 1929, demonstram a grande repercussão desse debate, que resultou em posicionamentos controversos e distintos sobre a

\footnotetext{
${ }^{535}$ LOBATO, M. O choque das raças. A Manhã: Rio de Janeiro, 01 de outubro 1926, ano II, n. 237, p. 5.
} 
política de imigrantes. A conferência O Problema Eugênico da Imigração proferida por Azevedo Amaral foi a que mais gerou discussões neste Congresso. Em seu discurso, Amaral apresentou posição contrária ao ingresso de imigrantes sem uma seleção prévia dos mesmos. Sugeriu um processo e triagem individual dos estrangeiros, propondo que fosse exigido a "posse de títulos"536 e os "contratos anteriormente feitos no país com técnicos especializados" 537 . Julgava, pois, que a entrada de imigrantes apenas pela sua nacionalidade não garantiria uma melhora nacional, visto que a ciência já havia comprovado que o que definia a superioridade de um povo, mais do que a sua raça, eram as doenças degenerativas transmitidas hereditariamente.

Em contrapartida, para Roquete-Pinto, a educação ${ }^{538}$ era o meio pelo qual os indivíduos assimilariam os preceitos eugênicos e se tornariam intelectualmente superiores e civilizados. Sendo assim, as sugestões restritivas propostas por Amaral não seriam suficientes, uma vez que o próprio Estado brasileiro poderia tomar medidas para solucionar os inconvenientes da imigração. Posto que este era, em sua opinião, um problema político e não eugênico $^{539}$. Por outro lado, o médico Belisário Penna declarava ser necessário apenas medidas para orientar a imigração de modo a "permitir sua assimilação à raça brasileira" 540 . Era indispensável que houvesse uma interação social dos novos imigrantes com os brasileiros; como exemplo, citou o estado do Rio Grande do Sul, onde as culturas italiana e alemã estavam "verdadeiramente encistadas no país, não se fundindo com as nacionais" ${ }^{\text {"51 }}$ e não auxiliando o processo de miscigenação do país.

Azevedo Amaral continuou afirmando que era dever do Estado legislar contra a entrada dos imigrantes indesejáveis, e que seu intuito não era suspender a imigração, mas sim,

evitar a entrada de elementos 'inferiores' que sobrecarregassem o contingente 'lastimável de atraso e perturbação social'. O autor dizia que uma política rigorosa de seleção imigratória não teria consequências negativas comparadas europeias à 'ruína racial' proporcionada pela imigração 'promíscua'. 542

\footnotetext{
${ }^{536}$ CONGRESSO BRASILEIRO DE EUGENIA. Rio de Janeiro, 1929. Actas e trabalhos. Rio de Janeiro: s. n., 1929. v.1. 342 p. 613.94 C76. reg. 8328/06 ex.3. p. 17.

537 Idem.

${ }^{538}$ Ibidem, p. 14. Vale ressaltar que Roquete-Pinto acreditava que todos eram capazes assimilar conhecimento e, assim, aprimorar-se.

539 Ibidem, p. 20.

540 Ibidem, p. 18.

${ }^{541}$ Idem.

${ }^{542}$ GONÇALVES, Assis da Silva. Eugenia em debate: Medicina e Sociedade no I Congresso Brasileiro de Eugenia. XIV Encontro Regional da ANPUH-RIO - Memória e Patrimônio. Rio de Janeiro, julho de 2010. p. 8. Disponível 
Vale notar que, quando Amaral menciona o imigrante como "indesejável" e "inferior", ele não estava se referindo à raça negra ${ }^{543}$ (como muitos o faziam) e isso acabou sendo alvo de diversas críticas. Dr. Salles Filho, por exemplo, não estava de acordo quanto a não inclusão do elemento negro nas restrições imigratórias, pois acreditava que somente pelo casamento entre raças superiores se conseguiria solucionar o problema da miscigenação ${ }^{544}$. Esse posicionamento ganhava força devido às avaliações feitas na região Sul do país que possuía um número relevante de imigrantes europeus. São Paulo, Paraná, Rio Grande do Sul, Santa Catarina e Rio de Janeiro demonstravam estar "em plena fase de arianização"545, diferentemente das regiões Norte e Nordestes, onde os seus habitantes estariam condenados a sucumbir enquanto raça.

Percebe-se, mais uma vez, que Lobato dá voz a Miss Jane para reproduzir o seu posicionamento frente ao debate científico de sua época. Para explicar os benefícios da utilização da eugenia, Lobato paulatinamente introduz o leitor desavisado nesse debate. Para fundamentar sua teoria final, demonstra os motivos pelos quais os ianques poderiam ser considerados superiores ao povo brasileiro. Além das "ondas sucessivas" dos melhores tipos europeus, as "leis restritivas" de imigração ajudaram a configurar uma raça mais estável e heterogênea, uma vez que selecionavam todos aqueles que queriam entrar no país. Feito isso, o norte-americano era o "único povo idealista que floresc[ia] no mundo",546.

A criação de uma ficção permeada por propagandas eugênicas e políticas de miscigenação, bem como um desfecho que enfatiza a necessidade do controle da imigração, especialmente, da contenção do elemento negro, onde a solução final foi a comovente esterilização dos negros norte-americanos, demonstram que seu autor estava em consonância com os preceitos da eugenia. Portanto, acreditamos que o beijo final é o grande enigma do romance porque é suscetível a diferentes interpretações. Propositalmente, Lobato deixa em aberto a conclusão de sua história para que os leitores tentem desvendar o sentido daquele final aparentemente estranho. Dessa maneira, denota um romance qualquer para os leitores desavisados e desatentos, ao mesmo tempo que instiga práticas radicais para aqueles que se

$<$ http://www.encontro2010.rj.anpuh.org/resources/anais/8/1276697830_ARQUIVO_MedicinaeSociedadenoICo ngressoBrasileirodeEugenia.pdf $>$. Acesso em: abril 2014.

${ }^{543}$ Não que o conferencista fosse a favor da inserção dos negros, muito pelo contrário. Ele não inclui nas restrições os negros porque já havia sido rejeitada pelo Congresso a proposta da proibição da entrada no país de qualquer elemento não pertencente à raça branca. CONGRESSO BRASILEIRO DE EUGENIA, op. cit. p. 20.

${ }^{544}$ Ibidem, p. 19.

${ }_{545}$ MOTA, André. Quem é bom já nasce feito: sanitarismo e eugenia no Brasil. DP\&A: Rio de Janeiro, 2003. p. 55

${ }_{546}^{5}$ LOBATO, M. O choque das raças. A Manhãa: Rio de Janeiro, 12 de outubro 1926, ano II, n. 221, p. 5. 
comprovaram dignos de sua compreensão. Ao fornecer elementos que justificassem a implementação da seleção artificial, Lobato acaba por sugerir que somente os "bons" e "adequados" poderiam se reproduzir. O que não deixa de ser um tipo de esterilização indireta, tendo em vista que os elementos disgênicos e "ruins" não seriam selecionados e sofreriam as consequências da não reprodução de seus caracteres.

\section{Monteiro Lobato, um apóstolo eugenista}

A leitura de $O$ Choque das Raças faz com que o leitor se questione acerca de sua realidade enquanto país miscigenado, uma vez que propõe critérios de seleção e uma postura científica eugênica. A intenção do autor é demonstrar que o choque entre as raças branca e negra era inevitável, e que, por isso, clamava pela prática eugênica mais extremista. Nesse sentido, a criação de uma narrativa ambientada tanto no Brasil como Estados Unidos, serve como parâmetro para justificar que, para realidades distintas, faziam-se necessárias soluções também distintas.

Consideramos que a vontade de arquitetar uma sociedade perfeita e evoluída foi o que impulsionou Lobato e os demais intelectuais da primeira década do século XX a depreender esforços nas discussões sobre a origem e as particularidades da sociedade brasileira. Eles se moveram "nos incômodos limites que os modelos [teóricos e científicos] lhes deixavam" 547 e formularam suas próprias ideias ao molde da realidade nacional. Posto que o Brasil ainda não possuía um "tipo genuinamente nacional" 548 a questão da heterogeneidade da população surgia como uma mácula digna de ser aprimorada e até mesmo suprimida. Levando em consideração a movimentação intelectual em busca das origens brasileiras e de alguns esquecimentos $^{549}$, com disposição para explicar o que era o Brasil, a ambição dessa classe pensante era, ao seu modo, nacionalista.

Num "delírio criativo" 550 , o literato paulista escreveu $O$ Choque das Raças no qual Ayrton Lobo narra a história das eleições presidenciais dos EUA de 2228. Porém, vemos tudo pela perspectiva de Miss Jane, que assumindo a tarefa de ensiná-lo os preceitos eugênicos,

\footnotetext{
${ }_{547}$ SCHWARCZ, L. M. Espetáculo da Miscigenação... p. 139-140

${ }^{548}$ HABIB, Paula A. B. B. Mundo Encantado que Monteiro Lobato Criou... p. 102.

549 Segundo Benedict Anderson, as nacionalidades são marcadas "por algumas lembranças e muitos esquecimentos. Cf.: ANDERSON, B. R. Comunidades imaginadas: reflexões sobre a origem e a difusão do nacionalismo; tradução: Denise Bottman. São Paulo: Companhia das Letras, 2008. p. 9.

${ }^{550}$ HABIB, Paula A. B. B. Saneamento, eugenia e literatura... p. 6.
} 
passa a conduzi-lo nessa jornada científica. A construção de um espaço-temporal duplo, presente e futuro (distante), como recurso narrativo principal deste romance, pode parecer uma espécie de fuga e isenção de culpa ${ }^{551}$ do autor. Contudo, acreditamos que, mais do que se livrar do que já foi dito, Lobato tinha como intenção demonstrar aos brasileiros os resultados da prática da eugenia, e para tanto, utilizou-se de uma projeção do futuro para abordar as diferenças "inatas" e essenciais entre brasileiros e norte-americanos.

Vejamos: o presente simboliza o ano de 1926, os debates sobre raça, miscigenação, nação e sociedade, sugere um espaço de indeterminação, questionamento e diálogo. O futuro, em 2228, representa as consequências da aplicação das leis e normas eugênicas; é lugar de certezas, afirmações e determinação. As dúvidas que pairavam sobre o destino de uma sociedade miscigenada e sobre os benefícios de uma política eugênica no Brasil de 1926 se encerram a partir do momento em que uma máquina do tempo mostra anos depois os resultados positivos alcançados com a prática da eugenia nos Estados Unidos. A elaboração de um enredo permeado de elementos já então determinidos dava respaldos para que Lobato propusesse sua "sábia ciência", e apresentasse uma solução eugênica nacional distinta daquela dos norte-americanos.

O choque entre brancos e negros no romance se deu porque a eugenia havia cuidado de todos os elementos disgênicos da sociedade norte-americana, com exceção do negro. De acordo com Lobato, enquanto ele prevalecesse não haveria harmonia social, porque, embora segregado do branco, o negro continuaria a manchar a sociedade e a lutar pela sua sobrevivência e poder. Fundamentalmente, ele não era confiável. Deste modo, a esterilização apresentava-se como a grande aspirina para a dor de cabeça histórica norte-americana do futuro. Embora haja uma relação direta entre EUA x Brasil, acreditamos que Lobato não propõe a esterilização dos negros no Brasil porque, sobretudo, prevê a miscigenação seletiva e supervisionada como produtora de indivíduos mais brancos de composição genética superior. Além disso, a mistura racial desregrada ocorrida no Brasil dificultava qualquer medida radical como a proposta para o futuro dos EUA.

Ao passo que a lógica de uma narrativa circunscrita numa visão do futuro pode determinar um fim e um resultado prático da ciência, ela também suscita alguns questionamentos sobre o assunto. É bem provável que uma dúvida em especial tenha atinado

${ }^{551}$ LAJOLO, Marisa. A figura do negro em Monteiro Lobato. Presença Pedagógica. Editora Dimensão. Belo Horizonte, v. 04, n. 23, set/out 1998. p. 4. Disponível em: <http://www.unicamp.br/iel/monteirolobato/outros/lobatonegros.pdf> Acesso em: março 2014. 
os leitores d'A Manhã. Ora, se o Professor Benson e sua filha tinham o poder de enxergar o futuro, por que a história não conta se Ayrton Lobo foi visto alguma vez nos "cortes anatômicos"? Miss Jane teria encontrado o seu companheiro nas suas aventuras pelo futuro? Se tudo já estava pré-determinado, seria razoável, e até mesmo natural, que pai e filha tivessem se certificado previamente das qualidades eugênicas de Ayrton Lobo dando uma espiadela no futuro na sua sofisticada engenhoca.

A incerteza do presente construída no romance sugere, para nós, que, independentemente da visão, Miss Jane deveria testá-lo e selecioná-lo para, enfim, poder aceitá-lo como seu companheiro. Afinal, o porviroscópio era uma invenção de Lobato. Na vida real, a seleção eugênica deveria ser realizada por meio de um protocolo próprio, seguindo um caminho fundamentalmente indiciário. Era preciso juntar peças de um delicado quebra-cabeças, como fez Miss Jane meticulosamente nos seus encontros com Ayrton Lobo. Nesse sentido, a união entre o narrador e a bela filha do professor Benson é muito representativa, pois demonstra os princípios eugênicos de Monteiro Lobato, o qual vislumbrava na seleção dos matrimônios um meio de trabalhar em prol da nação. Portanto, acreditamos que a construção das noções espaço-temporais são fundamentais para a estratégia didática do romance, pois, o autor formulou uma análise comparativa com a intenção de capturar a atenção e seduzir seus leitores com suas ideias e princípios.

O caráter "evangelizador" é evidenciado com algumas características de publicação. O teor da narrativa, a impressão num jornal popular, as estratégias e artifícios literários, e, especialmente, as publicações diárias do romance, esclarecem as intenções lobatianas com $O$ Choque. Ler o romance em seu lugar primeiro de publicação é completamente diferente de lêlo em livro. No jornal o leitor não tem autonomia na leitura, é obrigado a fazer as pausas diárias de acordo com a folha e, sem perceber, é conduzido a refletir sobre os assuntos ali apresentados. Com essa leitura dirigida, Monteiro Lobato trazia em seus desfechos pontos inquietantes e cruciais relacionados à raça e eugenia. Assim, ao longo de 21 dias "ministrou" aulas sobre a "sábia eugenia". De forma palatável, transformou a literatura numa ferramenta em prol da ciência. Essas observações somente são possíveis com a leitura do romance no jornal.

Portanto, a compreensão particular de Monteiro Lobato para com as sensibilidades do mundo o fez transparecer suas ideologias, seus questionamentos e suas inquietações a respeito do universo no qual vivia por intermédio da literatura. Mesmo que tenha recebido críticas 
positivas sobre o seu único romance, acreditamos que as negativas ${ }^{552}$ tocaram fundo o nosso literato falido em busca de ressureição. Não conseguimos delimitar nem saber ao certo como o romance foi lido e interpretado pelas camadas populares, contudo, sabemos que a sua receptividade não foi tão boa como suas obras anteriores. Encontramos poucos textos na imprensa nos quais há menção ao $O$ Choque e há também um grande silêncio por parte de Lobato, sempre orgulhoso de suas produções e repercussões. A edição deste romance em livro pode ter sido mais uma tentativa de inserir a obra no meio literário e conquistar o público mais letrado. No entanto, parece que tudo foi por água abaixo, porque, por mais difícil que seja comprovar e identificar a causa real do sucesso ou fracasso de vendas de um livro, sabemos que ele não ficou na boca do povo nem nas estantes das livrarias.

No jornal A Manhãa, poucos dias após o término da publicação do romance, o crítico literário Faria Neves Sobrinho ${ }^{553}$ demonstrou grande insatisfação com a obra. A princípio enaltece a produção literária lobatiana, da mesma forma que elogia a sua atuação como editor. No entanto, o texto começa a ficar ardiloso quando fala na recente obra do escritor. Ironizando, diz que Lobato, "afeito a pintar cenas observadas, dando-lhes com seu estilo, a impressão mesma da realidade", agora escrevia "coisas imaginadas e sonhadas" que podiam vir a se tornar verdades, mas que também podiam "falhar por completo como tudo que era de esperar do talento robusto do escritor paulista". De forma impiedosa, o crítico tocava na grande ferida de Lobato, o então arruinado editor. Faria Neves Sobrinho não mediu suas palavras e atacou $O$ Choque como uma produção "ilógica e impatriótica".

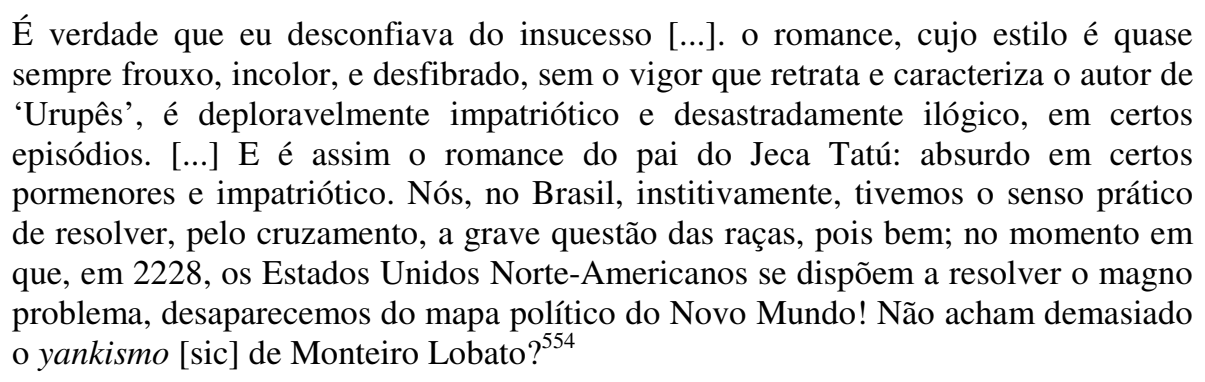

Concordamos quando o crítico qualifica o romance como "desastradamente ilógico", pois na trama faltam acontecimentos que justifiquem algumas ações e situações, tampouco as histórias são bem amarradas e ligadas umas às outras. De fato, a narrativa não é bem

\footnotetext{
552 Tivemos acesso e ciência de apenas uma crítica negativa sobre o romance.

${ }^{553}$ SOBRINHO, Faria Neves. "O príncipe de Nassau” e "O Choque das Raças". A Manhã: Rio de Janeiro, 19 de outubro 1926, ano II, n. $252, \quad$ p. $3 . \quad$ Disponível em: <http://memoria.bn.br/DocReader/DocReader.aspx?bib=116408\&PagFis=1367>. Acesso em janeiro 2015. ${ }^{554}$ Idem.
} 
estruturada e os eventos são "lançados" de formas muitas vezes incompreensíveis. O final fica em aberto porque Monteiro Lobato queria que os leitores chegassem a suas próprias conclusões e que fossem capazes de compreender o enigma final ${ }^{555}$. Dessa forma, essa produção literária é sujeito à algumas possibilidades de sentidos e interpretações. A visão de Sobrinho é uma delas, que entendeu o elogio exacerbado às terras do Tio Sam como “deploravelmente impatriótico".

Por outro lado, em 1927, Lobato recebeu críticas positivas de alguns escritores e críticos. No jornal $A B C$, Mario Vilalva diz que o romance é "uma charge habilíssima do futuro, num avanço de três séculos, onde, no entanto, muita coisa há que aproveitar para o presente" ${ }^{, 56}$. N'O Imparcial, Carlos Maul, numa "conversa fiada ao redor da novela de Monteiro Lobato" ${ }^{, 557}$, destaca os efeitos dos Raios Ômegas e demonstra que, embora o "Brasil ainda [seja] o "inferno dos pretos, o purgatório dos brancos e o paraíso dos mulatos", "558, a miscigenação tornava desnecessária a utilização da esterilização com o propósito de branquear a população. Villar Belmonte, numa crítica e análise mais detalhada n'O Jornal, conta como a temática do romance era atual, pois Lobato "não fez um drama científico, regional, mas a própria psicologia viva do momento sociológico" ${ }^{459}$ :

O 'Choque das Raças' equivale a uma profilaxia mental para os povos da América, um aviso aos lares e chancelarias - uma evangelização para a política científica, sul e norte americana. Apontam-se ali as duas grandes loucuras da época: a pretensa supremacia das raças inferiores e o histerismo social das mulheres que, perdendo a felicidade do lar e da prole, debalde a buscam recuperar nas lutas políticas. [...] Ayrton significa a natural inteligência do brasileiro; é um ginasiano qualquer, empregadinho de comércio, mas capaz de assimilar as concepções mais arrojadas da ciência moderna, como as interpretações profundas de Miss Jane sobre os altos temas de sociologia. 560

As observações mais minuciosas de Belmonte, assim como as demais referenciadas, mostram duas interpretações diferentes do romance, mas também possíveis. Lobato toca num

\footnotetext{
${ }^{555}$ Lobato acreditava que escrever era uma arte e que, por isso, cabia ao escritor a esperteza de construir uma narrativa na qual o leitor acreditasse em seu domínio da obra. Em missiva a Godofredo Rangel no ano 1915, dizia: "Em sua, o caso é de esperteza, como nas fábulas do jaboti. Fazer que o leitor puxe o carro sem o perceber. Sugerir. Arte é isso só.”. Cf.: LOBATO, M. A Barca de Gleyre... (t. 2), p. 14. Carta de 30.01.1915.

${ }^{556}$ VILALVA, Mario. Um romance de Lobato. ABC: São Paulo, 22 de janeiro de 1927, n. 620, p. 10. Disponível em: <http://memoria.bn.br/DocReader/DocReader.aspx?bib=830267\&PagFis=10556>Acesso em janeiro 2016.

557 MAUL, Carlos. O choque das raças. O Imparcial: Rio de Janeiro, 02 de fevereiro de 1927, n. 78 , p 3. Disponível em: <http://memoria.bn.br/DocReader/DocReader.aspx?bib=107670_02\&PagFis=29688> Acesso em janeiro 2016

558 Idem.

${ }^{559}$ BELMONTE, Villar. Ante-visões do futuro. O Jornal: Rio de Janeiro. 19 de março de 1927. Ano IX, n. 2544, p. 4. Disponível em: $<$ http://memoria.bn.br/DocReader/DocReader.aspx?bib=110523_02\&PagFis=31010> Acesso em janeiro 2016. 560 Idem.
} 
ponto delicado, reacende uma polêmica entre os intelectuais sobre qual seria a solução ideal para o problema racial do Brasil. "Sob a lente do microscópio e da máquina fotográfica",561, o Brasil transformara-se em um laboratório social. Lobato, através da sua pena e com todas as suas angústias e aflições, buscou enxergar o verdadeiro problema nacional e descobrir uma saída para o impasse brasileiro. Logo, ao "diagnosticar os problemas [nacionais], indicava o remédio necessário" ${ }^{\$ 562}$. Produzindo um saber utopista ${ }^{563}$ e nacionalista, utilizou-se da literatura como "um processo indireto de fazer eugenia" Choque das Raças um "projeto de hegemonia burguesa que não se concretizou" ${ }^{265}$, e que tampouco obteve sucesso. Esta obra representava o fim do "sonho americano"566, tão almejado durante a vida do literato.

Bem que ele tentou organizar algumas ideias soltas do romance na edição do livro, no entanto, essas modificações não foram suficientes para deixar a obra no ponto do sucesso e suprisse suas espectativas. É digno de notar que evidencia-se com a leitura do romance no jornal e depois no livro (na primeira edição), primeiramente, uma interpretação diferente, e também alterações de linguagem e estruturas ${ }^{567}$. Deparamo-nos com muitas mudanças de palavras por outras sinônimas, como, por exemplo: "meu invento" para "a minha maravilhosa descoberta" $" 568$. No capítulo XV, Vésperas do pleito, a título de exemplo, Ayrton encontra-se com Miss Jane que revela sofrer com a recente morte de seu pai, e procura afago em suas mãos. No jornal a frase é curta e simples: “Miss Jane comovida apertou-me a mão". Contudo, na primeira edição do livro encontramos um grande acréscimo de orações:

Miss Jane, comovida, apertou-me a mão. Irmanávamo-nos dia a dia, à medida que as nossas afinidades se iam revelando. Afinidades mentais e de sentimentos. Apesar da aparente divergência das nossas ideias, eu via que, no fundo, pensávamos da mesma forma. Quem ali nos visse a conversar da vida futura, juraria que éramos amigos

\footnotetext{
${ }_{561}^{561}$ SANTOS, Ricardo Augusto dos. Lobato, os Jecas e a questão racial no pensamento social brasileiro... p. 13. 562 Idem.

${ }^{563}$ Igualmente Cassal: "no sentido da busca da cidade ideal, forjando, por intermédio de sua obra, condições de vida e de educação mais favoráveis para alcançá-la”. CASSAL, Sueli A. T. B. op. cit., p. 14.

${ }^{564}$ LOBATO apud DIWAN, Pietra. op. cit., p. 111-112.

${ }^{565}$ CAMPOS, André L. V. op. cit., p. 16.

566 NUNES apud TIN, Emerson. Em busca do "Lobato das cartas": a construção da imagem de Monteiro Lobato diante de seus destinatários. Campinas, SP. [s/n], 2007. Tese (Doutorado), Universidade Estadual de Campinas, Instituto de Estudos da Linguagem. p. 153.

$567 \mathrm{Na}$ releitura dos textos em suporte diferentes, encontra-se com frequência reformulações de linguagem variadas que, ainda que não hajam regularidades, não alteram o sentido do texto. Há acréscimos de frases, alterações nominais, trocas de sinônimos, retiradas de trechos e acréscimos. Observa-se que algumas dessas alterações no livro servem para harmonizar melhor a história do romance entre Jane e Ayrton. Devido ao espaço, não nos deteremos nessas análises.

${ }^{568}$ LOBATO, M. O choque das raças. A Manhã: Rio de Janeiro, 5 de setembro 1926, ano II, n. 215, p. 1; e LOBATO, M. O Choque das Raças ou o Presidente Negro: romance americano do ano de 2228. Rio de Janeiro: Companhia Editora Nacional, 1926. p. 32.
} 
velhos ou parentes próximos - e outra não era a minha impressão. Parecia-me conhecê-la de séculos e não ter convivido nunca com outra pessoa. A menor sombra que passasse pela sua alma logo se refletia na minha. Suas alegrias eram as minhas e minhas as suas tristezas. ${ }^{569}$

O romance que outrora simplesmente acontecia do dia pra noite, num passada de folha, começara naquele momento a ser reanalisado e reconstruído. No livro, Lobato da mais voz a Ayrton e espaço para a sua história de amor com Jane. Da mesma forma, busca organizar melhor os conceitos e teorias eugênicas. No encerramento da história, no encontro entre os líderes negro e branco, muitas frases são acrescentadas. Enquanto no jornal Kerlog se apresenta a Jim Roy como "o homem que vem assassinar-te", no livro são adicionadas as seguintes sentenças:

\footnotetext{
- A raça ariana não poderia prestar maior homenagem à raça negra do que elegendo para carrasco de Jim Roy tão nobre chefe. Que arma escolhe para a missão que traz, presidente Kerlog? Veneno dos Bórgias ou lâmina de aço?

O tom faceto de Jim Roy não desanuviou o ar sinistro do líder branco, antes o fez ainda mais doloroso.

- Minha linguagem não é figurada, Jim. Venho de fato assassinar-te, repito.

Jim continuou a sorrir.

- E eu repito: com o punhal de Brutus ou com o veneno dos Bórgias?

Kerlog encarou-o com infinita piedade e disse:

- Arma pior, Jim. Trago na boca a palavra que mata...

O sorriso que pairava nos lábios do negro começou a desaparecer. ${ }^{570}$
}

Acreditamos que essas inserções dessas frases trazem maior dramaticidade ao romance. Nesse sentido, a narrativa torna-se mais organizada e descritiva, ao mesmo tempo em que os acontecimentos foram melhor estruturados e detalhados. A palavra raça é trocada por sangue, e o branco ganha mais elogios e exaltações. Contudo, apesar do grande número de modificações, o sentido geral do texto permanece o mesmo. O que muda, de fato, são as pausas e as consequentes reflexões que só existem na leitura do jornal.

Suporte de divulgação, leitura direcionada, pausas propositais, habilidade literária e conclusão ambígua, são algumas das características próprias da publicação de $O$ Choque das Raças no jornal que o tornam interessante e passível de estudos mesmo quase cem anos depois. O romance não foi obra do acaso, muito menos escrito sem propósitos, é, sobretudo, resultado das observações e anseios nacionalistas do literato eugenista. Do mesmo modo, é também um empreendimento econômico, uma tentativa de reinserir seu nome no meio literário e alcançar novamente sucesso com suas obras. O romance futurista-eugenista pode ser visto como a maneira pela qual Lobato tentou se reinventar e encontrou para ser moderno.

\footnotetext{
${ }^{569}$ LOBATO, M. O Choque das Raças ou o Presidente Negro... p. 161-162.

${ }^{570}$ Ibidem. p. 253-254
} 
As problematizações do romance lido no jornal que aqui trouxemos a tona servem para compreendermos a intricada relação entre a obra e o seu contexto sócio-político. Certamente, sem a leitura n'A Manhã não seria possível os diversos questionamentos levantados, pois a sua estrutura e as pausas abruptas levam a diferentes possibilidades de leituras. Assim, os múltiplos sentidos desta publicação e da realidade de 1926, nos ajudaram a compreender Monteiro Lobato e, por conseguinte, seu único romance. Acreditamos que, por intermédio das escolhas dos caminhos de pesquisa e das nossas fontes, conseguimos encontrar uma maneira de ler $O$ Choque das Raças de forma densa, equiparando contexto histórico às experiências de seu escritor. Assim, dando sentido e interpretações para as elucidações de Monteiro Lobato. 


\section{Referências bibliográficas}

\section{Fontes:}

A Manhã. Rio de Janeiro,1926. Consulta: Hemeroteca Digital Brasileira.

CONGRESSO BRASILEIRO DE EUGENIA. Rio de Janeiro, 1929. Actas e trabalhos. Rio de Janeiro: s. n., 1929. v.1. 342 p. 613.94 C76. reg. 8328/06 ex.3.

\section{Biblioteca Lobatiana. BR UNICAMP IEL/CEDAE BL.}

Correio da Manhã. Rio de Janeiro, 1918-1926. Consulta: Hemeroteca Digital Brasileira.

Correio Paulistano. São Paulo, 1918-1926. Consulta: Hemeroteca Digital Brasileira.

Gazeta de Notícias. Rio de Janeiro. 1918-1926. Consulta: Hemeroteca Digital Brasileira.

LOBATO, M. O Choque das Raças ou o Presidente Negro: romance americano do ano de 2228. $1^{\text {a }}$ ed. Rio de Janeiro: Companhia Editora Nacional, 1926.

. A Barca de Gleyre. (t. 1, 2). São Paulo: Brasiliense, 1961.

Cartas escolhidas. São Paulo: Brasiliense, 1959. v. 1 e 2.

. Conferências, artigos e crônicas. São Paulo: Brasiliense, 1959. v.15.

Prefácios e entrevistas. 8.ed. São Paulo: Brasiliense, 1957. v.13.

. Urupês. 37ª ed. São Paulo: Editora Brasiliense, 1994.

Cidades Mortas. $2^{\mathrm{a}}$ ed. São Paulo: Globo, 2009. p. 171.

Mr. Slang e o Brasil e Problema Vital. 11 a ed. São Paulo: Ed. Brasiliense,

1964.

\section{Bibliografia:}

ANDERSON, B. R. Comunidades imaginadas: reflexões sobre a origem e a difusão do nacionalismo; tradução: Denise Bottman. São Paulo: Companhia das Letras, 2008. p. 32.

AZEVEDO, C. L; CAMARGOS, M.; SACCHETTA, V. Monteiro Lobato: furacão na Botocúndia. $3^{\text {a }}$ ed. São Paulo: editora SENAC São Paulo, 2001.p. 30.

BARBOSA, Rui. A questão social e política no Brasil. CDU, 869.0(81) Lobato 7.07.

BIGNOTTO, Cilza. Monteiro Lobato em construção. p. 8. Disponível em: <http://www.unicamp.br/iel/monteirolobato/outros/cilza01Lobato.pdf>. Acesso em jan. 2014.

BRAVO! Revista. Maio de 2011, ano 13, n. 165, 
CAMPOS, André L. V. A República do Pica Pau Amarelo: uma leitura de Monteiro Lobato. São Paulo: Martins Fontes, 1986. p. 8.

CAMPOS, André. Raça ou doença? O Problema Vital do Brasil. Ipotesi: Revista de Estudos Literários, Juiz de Fora, vol. 1, nº 2 - p. 47.

CÂNDIDO, Antônio. A Personagem do Romance. In: CÂNDIDO, Antônio [et. Al]. A Personagem de Ficção. São Paulo: Perspectiva, 1968,

CÂNDIDO, Antônio. Literatura e sociedade. $9^{\circ}$ ed. Rio de Janeiro: Ouro sobre azul, 2006,

CARVALHO, Maria Alice R. de. Irineu Marinho: imprensa e cidade. São Paulo: Globo Livros, 2012,

CASSAL, Sueli Aparecida T. B. O Brasil visto verticalmente: uma constelação chamada Monteiro Lobato. 2003. 269 f. Tese (doutorado) - Universidade Federal do Rio Grande do Sul, UFRGS. Porto Alegre, Rio Grande do Sul, 2003.

Amigos escritos: quarenta e cinco anos de correspondêncialiterária entre Monteiro Lobato e Godofredo Rangel. SãoPaulo: Imprensa Oficial do Estado; Oficina do Livro Rubens Borbade Moraes, 2002.

CAVALHEIRO, Edgard. Monteiro Lobato: vida e obra. São Paulo: Companhia Distribuidora de Livro, 1955. p. 23.

CAVALHEIROS, E. A correspondência entre Monteiro Lobato e Lima Barreto. Os cadernos de cultura: Ministério da Educação e Cultura, 1955

CHIARELLI, Tadeu. Um Jeca nos Vernissages: Monteiro Lobato e o desejo de uma Arte Nacional no Brasil. São Paulo: Editora da Universidade de São Paulo, 1995. p. 219.

COSTA, Jurandir Freire. História da Psiquiatria no Brasil: um corte ideológico. $3^{\mathrm{a}}$ ed. revisada. Rio de Janeiro: Editora Campus, 1980.

CUNHA, Maria Clementina Pereira. O Espelho do Mundo: Juquery, A História de um Asilo. Rio de Janeiro: Paz e Terra, 1986.

DIAZ, José-Luis. Qual genética para as correspondências. In: Manuscrítica. Revista de Crítica Genética. Trad. Cláudio Hiro e Maria Sílvia IanniBrasalini, $\mathrm{n}^{\circ}$ 15, São Paulo: Humanitas, 2007.

DIWAN, Pietra. Raça Pura. Uma história da eugenia no Brasil e no mundo. Editora Contexto: São Paulo, 2007.

. O Espetáculo do Feio: práticas discursivas e redes de poder no eugenismode Renato Kehl. Dissertação (Mestrado em História) - Pontifícia Universidade Católica deSão Paulo, São Paulo. 2003.

FERREIRA, Marieta M. Monteiro Lobato. Cpdoc, p. 2. Disponível em: $<$ http://cpdoc.fgv.br/sites/default/files/verbetes/primeirarepublica/LOBATO,\%20Monteiro.pdf> Acesso em fev. 2014. 
FORSTER, E. M. Aspectos do romance. Trad. Maria Helena Martins. 2a ed. Porto Alegre: Editora Globo, 1974

FREYRE, Gilberto. Casa-Grande \& senzala: Formação da família brasileira sob o regime da economia patriarcal. 51 a ed. rev., São Paulo: Global, 2006.

GALTON, F. Essays in Eugenics. The EugenicEducationSociety: London, 1909. p. 35.

GIBSON, Robert A. The negro holocaust: lynching and race Riots in the United States, 18801950. Disponível em < http://www.yale.edu/ynhti/curriculum/units/1979/2/79.02.04.x.html>. Acesso em fevereiro de 2016

GOFFMAN, Erving. Sintomas Mentais e Ordem Pública. In: FIGUEIRA, Sérculo A. (coord.). Sociedade e Doença Mental. Rio de Janeiro: Editora Campus, 1978.

GONÇALVES, Assis da Silva. Eugenia em debate: Medicina e Sociedade no I Congresso Brasileiro de Eugenia. XIV Encontro Regional da ANPUH-RIO - Memória e Patrimônio. Rio de Janeiro, julho de 2010. p. 8. Disponível em: <http://www.encontro2010.rj.anpuh.org/resources/anais/8/1276697830_ARQUIVO_Medicin aeSociedadenoICongressoBrasileirodeEugenia.pdf>. Acesso em: abril 2014.

GOUVÊA, Luzimar Goulart. O homem caipira nas obras de Lobato e de Mazzaropi: a construção de um imaginário. Dissertação (mestrado) - Universidade Estadual de Campinhas, Instituto de Estudos da Linguagem UNICAMP. Campinas, São Paulo, 2001.

GUILHON ALBUQUERQUE, J. A. Ordem Social e Desordem Mental. In: FIGUEIRA, Sérculo A. (coord.). Sociedade e Doença Mental. Rio de Janeiro: Editora Campus, 1978.

GUMBRECHT, Hans Ulrich. Em 1926: vivendo no limite do tempo. Tradução de Luciano Tiago. Rio de Janeiro: Record, 1999

HABIB, Paula A. B. B. "Eis o Mundo Encantado que Monteiro Lobato Criou”: Raça, Eugenia e Nação. 2003. 225 f. Dissertação (Mestrado) - Universidade Estadual de Campinas, Instituto de Filosofia e Ciências Humanas, UNICAMP. Campinas, São Paulo, 2003.

Saneamento, Eugenia e Literatura: os caminhos cruzados de Renato Kehl e Monteiro Lobato (1914-1926). XXIV Simpósio Nacional de História - ANPUH, 2007.

HALLEWELL, Laurence. O livro no Brasil: sua história. São Paulo: Editora da Universidade de São Paulo, 1985.

KEHL, Renato. Bio-Perspectivas: dicionário filosófico. Rio de Janeiro: Livraria Francisco Alves, 1938. p. 17.

KEHL, Renato. Eugenia e medicina social (problemas da vida). $2^{\mathrm{a}}$ edição, Livraria Francisco de Assis: Rio de Janeiro. 1923. Arquivo AEL, Coleção Paschoal Lemme, obras raras. Primeira edição lançada em 1920.

LAJOLO, Marisa. A figura do negro em Monteiro Lobato. Presença Pedagógica. Editora Dimensão. Belo Horizonte, v. 04, n. 23, set/out 1998. Disponível em: $<$ http://www.unicamp.br/iel/monteirolobato/outros/lobatonegros.pdf $>$. Acesso em: $16 \mathrm{mar}$. 2011. 
. O regionalismo lobatiano na contramão do modernismo. Remates de Males, Campinas, (7): 39-48, 1987.p. 2.

. Monteiro Lobato: a modernidade do contra. São Paulo: Brasiliense,1985. (Encanto Radical).

Monteiro Lobato: um brasileiro sob medida. São Paulo: Moderna,2000.

LAJOLO, M.; ZILBERMAN, R. Literatura infantil brasileira: História \& Histórias. 2.ed. São Paulo: Ática, 1985.

LAMARÃO, Sérgio. Os Estados Unidos de Monteiro Lobato e as respostas ao "atraso" brasileiro. Lusotopie. 2002/1: 51-68. p. 63. Disponível em $<$ http://www.lusotopie.sciencespobordeaux.fr/lamarao.pdf $>$. Acesso em fevereiro de 2016.

LIMA, Nísia Trindade; HOCHMAN, Gilberto. Condenado pela raça, absolvido pela medicina: o Brasil descoberto pelo Movimento Sanitarista da Primeira República. In: MAIO, Marcos Chor e SANTOS, Ricardo Ventura. Raça Ciência e Sociedade. Rio de Janeiro: Editora Fiocruz, 1996. pp. 23-40.

LUCA, T. R. de. A Revista do Brasil: um diagnóstico para a (N)ação. SãoPaulo, 1996. 332p. Tese (Doutorado) - Faculdade de Filosofia, Letrase Ciências Humanas, Universidade de São Paulo.

MAI, Lilian D.; ANGERAMI, Emília L. S. Eugenia Negativa e Positiva: significados e contradições. Rev. Latino-am Enfermagem, março-abril, 14(2): 251-8, 2006. Disponível em: $<$ http://www.scielo.br/pdf/rlae/v14n2/v14n2a15.pdf> Acesso em março 2010.

MAI, Lilian Denise. BOARINI, Maria Lucia. Estudo sobre forças educativas eugênicas no Brasil, nas primeiras décadas do século XX. Revista Ciência, Cuidado e Saúde. Maringá, v. 1, n. $1, \quad$ p. 129-132, jan.- jun. 2002. Disponível em: <http://www.slideshare.net/Leticiablogsala/estudo-sobre-foras-educativas-eug > Acesso em: 14 abr. 2010.

MARTINS, Milena R. Lobato edita Lobato: história das edições dos contos lobatianos. 2003. 418 f. Tese (doutorado) - Universidade Estadual de Campinas, Instituto de Estudos da Linguagem, UNICAMP. Campinas, São Paulo, 2003.

MARTINS, Milena R. Quem conta um conto... aumenta, diminui, modifica: o processo de escrita do conto lobatiano. Campinas, SP, 1998. Tese (Mestrado), Universidade Estadual de Campinas, Instituto de Estudos da Linguagem.

MORAES, Pedro R. B. de. O Jeca e a cozinheira: raça e racismo em Monteiro Lobato. Revista de Sociologia e Política. n. 8, 1997. p. 104. Disponível em: $<$ http://revistas.ufpr.br/rsp/article/view/39322> . Acesso em agosto 2015.

MOTA, André. Quem é bom já nasce feito: sanitarismo e eugenia no Brasil. DP\&A: Rio de Janeiro, 2003. p. 55

NEIVA, Artur; PENA, Belisário. Viagem científica pelo norte da Bahia, sudoeste de Pernambuco, sul do Piaíu e de norte a sul de Goiás. Ed. fac-similar. Brasília: Senado Federal, 1999. p. V 
NEVES, Margarida de Souza. Da maloca do Tietê ao Império do Mato Virgem. Mário de Andrade: roteiros e descobrimentos. In: CHALHOUB, Sidney, PEREIRA, Leonardo Affonso de Miranda. A História Contada: capítulos de história social da literatura brasileira. Rio de Janeiro: Ed. Nova Fronteira, 1998.

OLIVEIRA, William Vaz de. Intolerância étnica e racial: o pensamento eugenista no Brasil e o ideal de "purificação" das raças. Cadernos de Pesquisas do CDHIS, n. 36/37, ano 20, p. 7582, 2007.2 p. $79 . \quad$ Disponível em: $<$ http://www.seer.ufu.br/index.php/cdhis/article/viewFile/1219/1163> Acesso em agosto 2014.

QUAGLINO, Maria Ana. Noções de Raça e Eugenia em Monteiro Lobato: vida e obra. In: XI Encontro Regional de História ANPUH-RJ - Democracia e Conflito. 2004. Disponível em: $<$ http://www.google.com.br/url?sa=t\&rct=j\&q=\&esrc=s\&source=web\&cd=1\&ved=0CFMQF jAA\&url=http\%3A\%2F\%2Fwww.rj.anpuh.org\%2Fresources\%2Frj\%2FAnais\%2F2004\%2FS imposios\%2520Tematicos\%2FMaria\%2520Ana\%2520Quaglino.doc\&ei=16UNUOmPGKPi0 QH2usjWAw\&usg=AFQjCNG2OjH54AVU4c6HBwE0AdS2BP4fpA > Acesso em: julho de 2012.

QUELUZ, Gilson Leandro. Eugenias Modernistas: O Presidente Negro de Monteiro Lobato e a República 3000 de Menotti Del Picchia. Revista Tecnologia e Sociedade, Curitiba, n. 2, $1^{\circ}$ semestre de 2006.2 Disponível em: $<$ http://revistas.utfpr.edu.br/ct/tecnologiaesociedade/index.php/000/article/viewArticle/39> Acesso em: set. 2010.

ROSENFELD, Anatol. Literatura e Personagem. In: CÂNDIDO, Antônio [et. Al]. A Personagem de Ficção. São Paulo: Perspectiva, 1968.

SANTOS, Elisângela da Silva. Monteiro Lobato e suas seis personagens em busca da nação. 2008. Dissertação (Mestrado) - Faculdade de Filosofia e Ciências, Universidade Estadual Paulista, $\quad$ Marília, $2008 . \quad$ p. $14 . \quad$ Disponível em:<http://www.marilia.unesp.br/Home/PosGraduacao/CienciasSociais/Dissertacoes/santos es_me_mar.pdf> Acesso em: 06 ago. 2011.

SANTOS, Gislene Aparecida dos. A Invenção do Ser Negro: um percurso das idéias que naturalizam a inferioridade dos negros. São Paulo: Educ/Fapesp; Rio de Janeiro: Pallas, 2002.

SANTOS, R. C.Z. Transfigurações utópicas em O Presidente Negro de Monteiro Lobato. Disponível em<http://www4.pucsp.br/revistafronteiraz/numeros_anteriores/n4/download/pdf/lobato.pdf $>$. Acesso em janeiro de 2016.

SANTOS, Ricardo Augusto dos. "Eugenia, Saneamento e Educação. O Eugenismo de Renato Kehl (1917-37)". In: Anais do XI Encontro Regional de História - 2004, Rio de Janeiro, $2004 . \quad$ p. $8 . \quad$ Disponível em:<http://www.rj.anpuh.org/resources/rj/Anais/2004/Simposios\%20Tematicos/Ricardo\%20 Augusto\%20dos\%20Santos.doc > Acesso em: 07 mar. 2010.

. Lobato, os Jecas e a questão racial no pensamento social brasileiro. p. 4. Disponível em: <http://www.achegas.net/numero/sete/ricardo_santos.htm> Acesso em: julho de 2012. 
SCHWARCZ, Lilia Moritz. Espetáculo da Miscigenação. Estudos Avançados. 8(20), Universidade de São Paulo, 1994. 147p

. O espetáculo das raças: cientistas, instituições e questão racial no Brasil, 18701930. São Paulo: Companhia das Letras, $7^{\mathrm{a}}$ reimpressão, 2007

SEVCENKO, Nicolau. Literatura como missão: tensões sociais e criação cultural na Primeira República. $2^{a}$ ed. São Paulo: Companhia das Letras, 2003.

SKIDMORE, T. E. Preto no branco. Tradução Donaldson M. Garschagen. $1^{a}$ e. São Paulo: Companhia das Letras, 2012. p. 118.

SLENES, Robert W. "O Horror, O Horror". O contexto da formação de identidades mestiças no Rio de Janeiro dos anos 1920. In: GOMES, Tiago de Melo. Um espelho no palco: identidades sociais e massificação da cultura no teatro de revista dos anos 1920. Campinas, SP: Editora da Unicamp, 2004.

SOUZA, Vanderlei Sebastião de. "A Eugenia no Brasil: ciência e pensamento social no movimento eugenista brasileiro do entre-guerras". In: Anais do XXIII Simpósio ANPUH, Londrina, $2005 . \quad$ Disponível em: $<$ http://www.bioeticaefecrista.med.br/textos/eugenia\%20no\%20brasil_ciencia\%20e\%20pensa

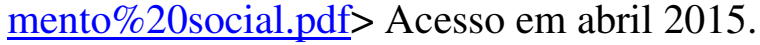

A "eugenia negativa" nos trópicos: a política biológica e a construção da nacionalidade na trajetória de Renato Kehl (1928-1932). XII Encontro de História Regional. Rio de Janeiro, 2006b. Disponível em: $<$ http://www.rj.anpuh.org/resources/rj/Anais/2006/conferencias/Vanderlei\%20Sebastiao\%20d e\%20Souza.pdf> Acesso em abril 2015.

Em nome da raça: a propaganda eugênica e as idéias de Renato Kehl nos anos 1910 e 1920. Revista de História Regional, 11(2): 29-70, 2006a. Disponível em: <http://www.revistas2.uepg.br/index.php/rhr/article/view/2230>. Acesso em abril 2010.

STANCIK, Marco Antônio. Os Jecas do Literato e do Cientista: Movimento Eugênico, Higienismo e Racismo na Primeira República. UEPG Ci. Hum.,Ci. Soc. Apl., Letras e Artes, Ponta Grossa, n. 13 (1), p. 45-62, jun. 2005. p. 50. Disponível em: <http://www.revistas2.uepg.br/index.php/humanas/article/viewFile/535/536> Acesso em: ago. 2011.

Statistical Abstract of the United States: 2003, e We, The American Blacks, U.S. Census Bureau, 1993. Disponível em: <http://www.infoplease.com/ipa/A0922246.html>, acesso em janeiro de 2016.

STEPAN, Nancy Leys. A Hora da Eugenia: Raça, Gênero e Nação na América Latina. Rio de Janeiro, Fiocruz, 2005. p. 9.

STEPAN, Nancy Leys. Eugenia no Brasil, 1917-1940. In: HOCHMAN, Gilberto, ARMUS, Diego. Cuidar, controlar, curar: ensaios históricos sobre saúde e doença na América Latina e Caribe. Rio de Janeiro: Editora Fiocruz, 2004. 
TIN, Emerson. Anedota ou doutrinação? A interpretação equivocada em três contos de Monteiro Lobato. Intersecções: revista de estudos sobre práticas discursivas e textuais. Ano 3, n. 1, abril, 2010.

VALENTE. Thiago A. Monteiro Lobato nas páginas do jornal: um estudo dos artigos publicados em O Estado de S. Paulo (1913-1923). São Paulo: Cultura Acadêmica, 2010. 